
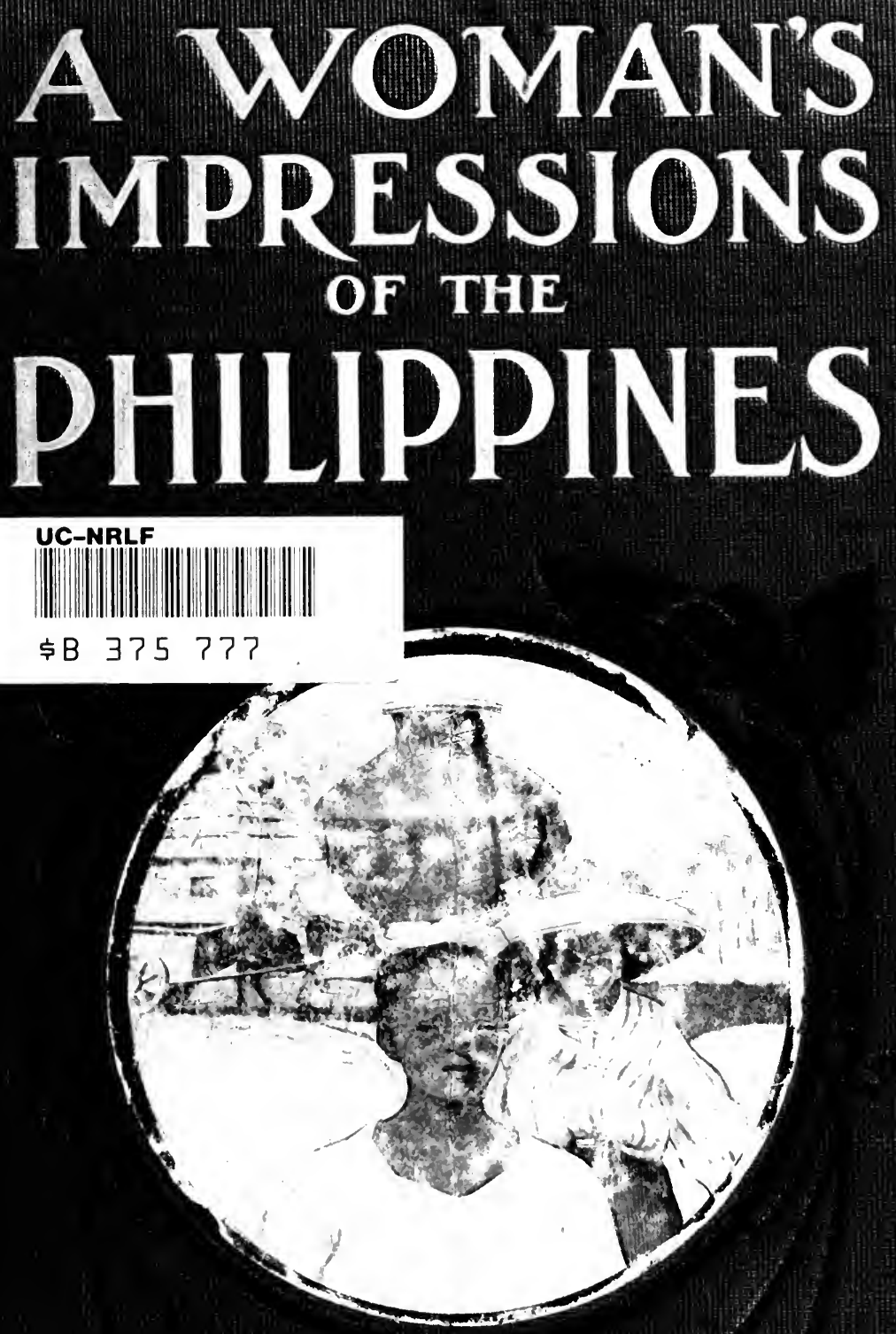

MARY H. FEE 

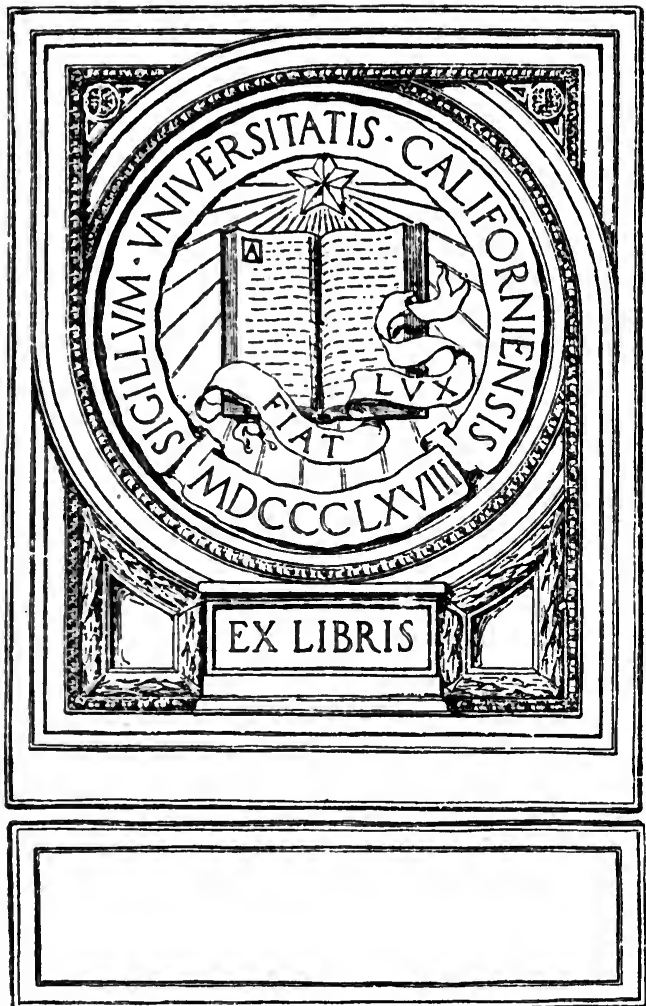




\section{A WOMAN'S IMPRESSIONS OF THE PHILIPPINES}


Digitized by the Internet Archive in 2007 with funding from Microsoft Corporation 


\section{A \\ WOMAN'S IMPRESSIONS \\ OF THE PHILIPPINES}

BY

MARY H. FEE

ILLUSTRATED FROM PHOTOGRAPHS

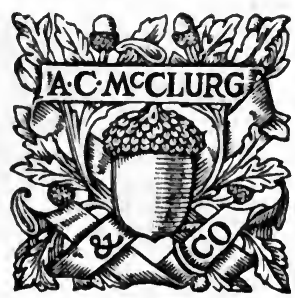

CHICAGO

A. C. MCCLURG \& CO.

1910 


\section{Copyrient}

A. C. McClurg \& Co.

1910

Published March 26, 1910

THE UXIVEROTTY PRES, CAMBRIDGE, U.S. A. 
TO

MY SCHOOLMATE AND LIFE-LONG FRIEND

\section{MARTHA PARRY GISH}

THIS BOOK

I8 AFFECTIONATELY DEDICATED 



\section{CONTENTS}

Chapter

Page

I. The Voyage Begins . . . . . . 11

II. From San Francisco to Honolulu - 21

III. Our Ten Days' Sightseeing • • . 26

IV. From Honolulu to Manila. . . 38

V. Our First Few Days in the City . 45

VI. From Manila to Capiz . . . . . 60

VII. My First EXPERIENCes as a Teacher

of FILIPINOS • • • • • • • • • 73

VIII. An Analysis of Filipino Character 86

IX. My Early Experiences in HouseKEEPING • • • • • • . • • 107

X. Filipino Youths and Maidens . . . 119

XI. Social and Industrial Condition of

the Filipinos . . . . . . . 130

XII. Progress in Politics and Improvement

OF THE CURRENCY . . . . . . 150

XIII. Typhoons and Earthquakes . . . 168

XIV. War Alarms and the Suffering Poor 179

XV. The Filipino's Christmas Festivities

AND his ReLigion • • . • . . 192 
Chapter

XVI. My Gold-hunting Expedition . • 206

XVII. AN Unpleasant Vacation . . . . 217

XVIII. The Aristocracy, the Poor, and Ameri-

CAN WOMEN . . . . . . . . 232

XIX. Wedings in Town and Country. . 250

XX. Sickbeds and Funerals • • • . 262

XXI. Sports and Amusements . • • . 270

XXII. Children's Games - The Conquest of

Fires . • • • • • • . • . 280 


\section{ILLUSTRATIONS}

PAGE Filipino School Children . . . . . . . . Frontispiece The Pali, near Honolulu . . . . . . . . . 28 West Indian Rain-tree, or Monkey-pod Tree, Honolulu 34 The Volcano of Mayón . . . . . . . . . . . 40 View of Corregidor . . . . . . . . . . . . 42 Swarming Craft on the Pasig River, Manila . . . . 46 "The Rat-pony and the Two-wheeled Nightmare" . 48 The Luneta, Manila . . . . . . . . . . 52

The Bend in the River at Capiz . . . . . . . . 62 Street Scene in Romblón . . . . . . . . . . 64 Church, Plaza, and Public Buildings, Capiz . . . 80 The Home of an American Schoolteacher . . . . 90 A Characteristic Group of Filipino Students . . . 100 Filipino School Children . . . . . . . 110 A Filipino Mother and Family . . . . . . . 120 A Company of Constabulary Police . . . . . . 132 Group of Officials in front of Presidente's (Mayor's) Residence . . . . . . . . . 142 
A High-class Provincial Family, Capiz . . . . 148 Pasig Church . . . . . . . . . . . 154 The Isabella Gate, Manila . . . . . . . . . 162 Calle Real, Manila . . . . . . . . . . 174 Procession and Float in Streets of Capiz, in Honor of Filipino Patriot and Martyr, José Rizal . . . 184 A Rich Cargo of Fruit on the Way to Market . . . 194 A Family Group and Home in the Settled Interior . . 200 Filipino Children "Going Swrimming" in the Rio Cagayan . . . . . . . . . . . . 212 Mortuary Chapel in Paco Cemetery, Manila . . . 220 The "Ovens" in Paco Cemetery, Manila . . . . 228 Peasant Women of the Cagayan Valley . • . . 236 A Wedding Party Leaving the Church . . . . 252 A Funeral on Romblón Island . . . . . . . 264 Bicol School Children One Generation Removed from Savagery . • . . . • . . . . . 272 Sunset over Manila Bay . • . . . . . . 282 
A WOMAN'S IMPRESSIONS OF THE PHILIPPINES 



\title{
A WOMAN'S IMPRESSIONS OF THE PHILIPPINES
}

\author{
CHAPTER ONE \\ THE VOYAGE BEGINS
}

I find the Transport Ship Buford and my Stateroom - Old Maids and Young Maids bound for the Orient - The Deceitful Sea - Making New Friends and Acquaintances.

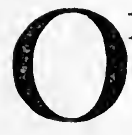

$\mathrm{N}$ a hot July day the army transport Buford lay at the Folsom Dock, San Francisco, the Stars and Stripes drooping from her stern, her Blue Peter and a cloud of smoke announcing a speedy departure, and a larger United States flag at her foremast signifying that she was bound for an American port. I observed these details as I hurried down the dock accompanied by a small negro and a dressingbag, but I was not at that time sufficiently educated to read them. I thought only that the Buford seemed very large (she is not large, however), that she was beautifully white and clean; and that I was delighted to be going away to foreign lands upon so fine a ship.

Having recognized with relief a pile of luggage going aboard - luggage which I had carefully pasted with red, white, and blue labels crossed by the letters "U. S. A. T. S." and Buford - I dismissed the negro, grasped the dressing-bag with fervor, and mounted the 
gangway. To me the occasion was momentous. I was going to see the world, and I was one of an army of enthusiasts enlisted to instruct our little brown brother, and to pass the torch of Occidental knowledge several degrees east of the international date-line.

I asked the first person I met, who happened to be the third officer, where I should go and what I should do. He told me to report at the quartermaster's office at the end of the promenade deck. A whitehaired, taciturn gentleman in the uniform of a major, U. S. A., was occupying this apartment, together with a roly-poly clerk in a blue uniform which seemed to be something between naval and military. When I mentioned my name and showed my order for transportation, the senior officer grunted inarticulately, and waved me in the direction of his clerk, glaring at me meanwhile with an expression which combined singularly the dissimilar effects of a gimlet and a plane. The rotund junior contented himself with glancing suspiciously at the order and sternly at me. As if reassured, however, by my plausible countenance, he flipped over the pages of a ledger, told me the number of my stateroom, and hunted up a packet of letters, which he delivered with an acid reproof to me for not having reported before, saying that the letters had been accumulating for ten days.

It is true that the Buford had been scheduled to sail on the first day of the month; but I had arrived a day or two before that date, only to learn that the sailing date had been postponed to the tenth. I had made many weary trips to the army headquarters in 
Montgomery Street, asking for mail - and labels with no results. Nobody had suggested that the mail would be delivered aboard ship, and I had not had sense enough to guess it. I did not make any explanations to the quartermaster and his clerk, however, because an intuition warned me not to add tangible evidence to a general belief in civilian stupidity. I merely swallowed my snubbing meekly and walked off.

I ambled about, clinging to the dressing-bag and looking for some one resembling a steward. At the foot of the ladder leading to the bridge I encountered two young girls descending therefrom with evidences of embarrassed mirth. They were Radcliffe girls, whose evil genius had led them to the bridge and to an indignant request to explain their presence there. They explained to no purpose, and, in response to a plaintive inquiry where to go, were severely told, "We don't know, but go down from here immediately." So they came down, crimson but giggling, and saw me (they said) roaming about with an expression at once wistful and complacent.

I found a steward and my stateroom at last, and a brown-haired, brown-eyed young woman in it who was also a pedagogue. We introduced ourselves, disposed of our parcels, and began to discuss the possibilities of the voyage. She was optimistically certain that she was not going to be seasick. I was pessimistically certain that I was. And she was wrong, and I was right. We were both gloriously, enthusiastically, madly seasick. 
When we returned to the deck, it was crowded with passengers, the mail was coming aboard, and all sorts of bugle-calls were sounding, for we were carrying "casuals." It was a matter of wonder that so many. persons should have gathered to bid adieu to a passenger list recruited from all parts of the Union. The dock was black with people, and our deck was densely crowded. Khaki-clad soldiers leaned over the side to shout to more khaki on the dock. An aged, poorly dressed woman was crying bitterly, with her arms about the neck of a handsome boy, one of our cabin passengers; and all about, the signs of intense feeling showed that the voyage marked no light interval of separation.

I stood at the forward rail of the promenade deck, and fell into conversation with a gentleman whom I had met in San Francisco and who was a fellow passenger. We agreed in being glad that none of our relatives were there to see us off; but, though we made much ado to seem matter-of-fact and quite strong-minded about expatriating ourselves, I noticed that he cleared his throat a great deal, and my chin annoyed me by a desire to tremble.

The gongs warned visitors ashore, and, just as all the whistles of San Francisco were blowing the noon hour, we backed away from the dock, and turned our head to sea. As the little line of green water between ship and dock widened to a streamlet and then to a river, the first qualm concerning the wisdom of the expedition struck its chilly - way to my heart. Probably most of the passengers were experiencing the 
same doubts; and the captain suspected the fact, for he gave us fire drill just to distract our attention and to settle our nerves.

The luncheon gong sounded immediately after his efficacious diversion, and the military people who were to eat in the first section - the Buford's dining-room was small - went down to lunch. The junior lieutenants, and the civil engineers and schoolteachers, who made up her civilian list, took their last look at San Francisco. We swung past Alcatraz Island and heard the army bugles blowing there. The irregular outline of the city with its sky-scrapers printed itself against a background of dazzling blue, with here and there a tufty cloud. The day was symbolic of the spirit which sent young America across the Pacific - hope, brilliant hope, with just a cloud of doubt.

We passed the Golden Gate just as our own luncheon gong sounded, and the Buford was rolling to the heave of the outside sea as we sat down to our meal. At our own particular table we were eight - eight nice old (and young) maid schoolteachers. Some of us were plump and some were wofully thin. One was built on heroic lines of bone, and those sinners from Radcliffe were pretty.

Toward the end of luncheon the Buford began to roll and pitch and otherwise behave herself "most unbecoming," and my room-mate, declining to finish her luncheon, fled to the deck, where the air was fresher. Feeling no qualms myself, and secretly triumphing in her disillusion, I followed with her golf cape and rug, of which she had been too engrossed to think. My 
San Francisco acquaintance coming to my assistance, we established her in a steamer chair and sat down, one on each side, to cheer her up, - and badly she needed it, for her courage was fast deserting her.

The sea was running heavily, and the wind was cold; I had not thought there could be such cold in July. The distance was obscured by a silvery haze which was not thick enough to be called a fog, but which lent a wintry aspect to sea and sky - a likeness increased by the miniature snow-field on each side of the bow as the water flung up and melted away in pools like bluish-white snow ice.

As the Buford waded into the swell, wave after wave dashed over the forward deck, drenching a few miserable soldiers there, who preferred to soak and freeze rather than to go inside and be seasick. Sometimes the spray leaped hissing up on the promenade deck, and our weather side was dripping, as I found when I went over there. I also slipped and fell down, but as that side of the ship was deserted, nobody saw me - to my gratification. I petted a bruised shin a few minutes and went back to the lee side a wiser woman.

About three o'clock, when Miss R-'s face was assuming a fine, corpse-like green tint, I began to have a hesitating and unhappy sensation in the pit of the stomach, a suggestion of doubt as to the wisdom of leaving the solid, reliable land, and trusting myself to the fickle and deceitful sea. In a few moments these disquieting hints had grown to a positive clamor, and my head and heels were feeling very much as do those of gentlemen who have been dining out with "terrapin 
and seraphim " and their liquid accompaniments. At this time Miss $\mathrm{R}$ - gave out utterly and went below, but I was filled with the idea that seasickness can be overcome by an effort of will, and stayed on, making an effort to "demonstrate," as the Christian Scientists say, and trying to look as if nothing were the matter. The San Francisco man remained by me, persistent in an apparently disinterested attempt to entertain me; but I was not deluded, for I recognized in his devotion the fiendish joy of the un-seasick watching the unconfessed tortures of those who are.

It was five o'clock when I gasped with a last effort of facetious misery, "And yet they say people come to sea for their health," and went below. The Farralones Islands, great pinky-gray needles of bleak rock, were sticking up somewhere in the silvery haze on our starboard side, and I loathed the Farralones Islands, and the clean white ship, and myself most of all for embarking upon an idiotic voyage.

Arrived in the stateroom, it was with little less than horror that I saw Miss R - in the lower berth - my berth. Such are the brutalizing influences of seasickness that I immediately reminded her that hers was above. She dragged herself out, and, in a very ecstasy of selfish misery, I discarded my garments and burrowed into the warmth of my bed. Never had blankets seemed more comfortable, for, between the wind and the seasickness, I was chilled through and through.

I fell asleep through sheer exhaustion, and wakened some time after in darkness. The waves were hissing and slapping at the porthole; the second steward was 
cursing expertly in the linen closet, which happened to be opposite our stateroom; and somewhere people in good health were consuming viands, for cooking odors and the rattle of dishes came to us. A door in the corridor opened, and the sound of a cornet was wafted back from the forward deck. Somebody was playing "The Holy City." Steps went by. A voice with an English accent said, "By Jove, you can't get away from that tune," and, in one of those instants of stillness which fall in the midst of confusion, I heard a gurgling moan.

I snapped on the light and turned - at what cost only the seasick can appreciate - to behold Miss Rsitting on the floor with her back to the wall. She was still shrouded in her golf cape and hood, and contemplated her boots - which were on her feet, sticking straight out before her - as if they were a source of mental as well as bodily inconvenience. At intervals she rolled her head and gave utterance to that shuddering moan.

Wretched as I was, I could not help gasping, "Are you enjoying your sea trip?" and she replied sepulchrally, "It is n't what it 's cracked up to be." We could say no more. That time we groaned in unison.

She must have gathered strength of mind and body in the night, however, for she was in her berth next morning when the stewardess came in to know what we wanted for breakfast. We did not want anything, as we quickly made reply. The wind went down that day; the next day was warm and clear, with a sea like sapphire, and we dragged ourselves to the deck. Re- 
covery set in quickly enough then, so that we began to "think scornful" of seasickness. Fortunately the good ship Buford ploughed her way across the Pacific without meeting another swell, and our pride was not humbled again. We ate quite sparingly for a meal or two, and had fits of abstraction, gazing at the ceiling when extra-odorous dishes were placed in front of us. The Radcliffe girls said that they had passed a strenuous night, engaged in wild manœuvres to obtain possession of the monkey wrench and feloniously to secrete the same. Their collegiate training had included instruction on the hygienic virtues of fresh air, which made no allowance for a sea trip; and their views as to the practical application of these principles came sadly into conflict with the ideas of their bedroom steward. There were frantic searchings for a monkey wrench all that night, while the article lay snugly bestowed between the mattresses of a maiden who looked as if she might be thinking of the angels. Also their porthole was open in defiance of orders, and much water came into their stateroom. But they did not care, for it brought fresh air with it.

The first two or three days of the voyage were spent in taking stock of our fellow passengers and in finding our friends. We were about seventy-five cabin passengers in all, - a small family, it is true. The ship was coaled through to Manila, the first stop being Guam. So we made acquaintance here and there, settling ourselves for no paltry five or six days' run, but for a whole month at sea. We all came on deck and took our fourteen laps - or less - around the promenade deck 
before breakfast. The first two or three nights, with a sort of congregational impulse, we drifted forward under the promenade awnings, and sang to the accompaniment of the cornetist on the troop deck. The soldiers sang too, and many an American negro melody, together with "On the Road to Mandalay" and other modern favorites, floated melodiously into the starlit silence of the Pacific. Our huge windsail flapped or bellied as the breeze fell or rose; the waves thumped familiarly against the sides; the masthead lantern burned clear as a star; and the real stars swung up and down as the bowsprit curtsied to each wave. In the intervals between songs a hush would fall upon us, and the sea noises were like effects in a theatre.

In a few days, however, our shyness and strangeness wore off. We no longer sang with the soldiers, but segregated ourselves into congenial groups; and under the electric lights the promenade deck looked, for all the world, like the piazza of a summer hotel. 


\section{CHAPTER TWO}

\section{FROM SAN FRANCISCO TO HONOLULU}

We change our Course and arrive at Honolulu - The City viewed from the Sea - Its Mixed Population - We are detained Ten Days for Engine Repairs.

W

THEN we were a week out from San Francisco and were eight hundred or a thousand miles north of the Hawaiian Islands, the Buford stopped one evening just at sunset, and for at least twenty minutes slopped about in the gentle swell. There is a curious sense of dulness when the engines cease droning and throbbing; and the passengers, who had just come up from dinner, were affected by the unusual silence. We hung over the rail, talking in subdued tones and noting the beauty of the sunset.

Behind us the sea lay purple and dark, with the same sad, sweet loneliness that a prairie has in the dusk; but between us and the sun it resembled a molten mass, heaving with sinister power. Our bowsprit pointed straight at the fiery ball hanging on the sky rim, above which a pyramidal heaping of clouds aped the forms of temples set on rocky heights. And from that fantastic mingling of gold and pink and yellow the sky melted into azure streaked with pearl, and faded at the zenith 
into what was no color but night - the infinity of space unlighted.

When the engines started up, the gorgeous picture swung around until it stood on what is technically called the starboard beam, whereupon one of the engineers called my attention to the fact that we had changed our course. Since we were then headed due south, he added, we must be bound for Honolulu.

Everybody was pleased, though there was some little anxiety to know the cause of this disregard of orders and of our turning a thousand miles out of our course. In an ordinary merchant ship doubtless somebody would have been found with the temerity to ask the captain or some other officer what was the matter, but nobody was fool enough to do that on an army transport. The "ranking" officer aboard was rather intimate with the quartermaster captain, and we hoped something might be found out through him; but if the quartermaster made any confidences to the officer, that worthy kept them to himself. We women went to bed with visions of fire in the hold, or of "tail shafts" ready to break and race. The night passed tranquilly, however, and the next morning there was no perceptible anxiety about the officers. As the Buford's record runs were about two hundred and sixty miles a day, the remembrance that something was wrong had almost faded before Honolulu was in sight.

We arrived at Honolulu during the night, and, the steward afterwards said, spent the second half of it "prancing" up and down outside the bar, waiting for 
the dawn. A suspicion that the staid Buford could prance anywhere would have brought me out of bed. I did rise once on my elbow in response to an excited whisper from the upper berth, in time to see a dazzle of electric lights swing into view through the porthole and vanish as the vessel dipped.

I dressed in time to catch the last of the sunrise, but when I went on deck, found that nearly half the passengers had been more enterprising than I. We were at anchor in the outer harbor, and Honolulu lay before us in all the enchantment of a first tropical vision. A mountain of pinky-brown volcanic soil - they call it Diamond Head - ran out into the sea on the right, and, between it and another hill which looks like an extinct crater and is called the Punch Bowl, a beach curved inward in a shining line of surf and sand. Back of this line lay some two or three miles of foreshore, covered with palm-trees and glossy tropical vegetation, from which peeped out the roofs and towers of the residence portion of the city. There were mountains behind the town, jagged sierra-like peaks with clefts and gorges between. They were terraced half-way up the sides and were covered with the light green of crops and the deeper green of forests. Tatters of mist draped them here and there, while clouds lowered in half a dozen spots, and we could see the smoky lines of as many showers in brisk operation.

On our left the shipping lay clustered about the wharfs, sending its tracery of masts into the clear sky; and all around glowed the beauty of a shallow harbor, coral-fringed. From the sapphire of the water in our 
immediate vicinity, the sea ranged to azure and apple green, touched by a ray of sunlight into a flashing mirror here, heaping into snow wreaths of surf there; and against this play of color loomed the swart bulk of the Pacific Mail steamer Coptic, flying her quarantine flag.

We watched the doctor's launch go out to her, saw the flag fall and the belch of smoke as she started shoreward, while the launch came on to us. In a little while we too were creeping toward the docks. Naked Kanaka boys swam out to dive for pennies. The buildings on the shore took shape. The crowd on the dock shaped itself into a body of normal-looking beings, interspersed with ladies in kimonos who were carrying babies on their backs (the Japanese population of Honolulu is very large), and with other dark-skinned ladies in Mother Hubbards decorated with flower wreaths. There were also numerous gentlemen of a Comanche-like physiognomy, who wore ordinary dress, but were distinguished by flower wreaths in lieu of hat bands. Here and there Chinese women loafed about, wearing trousers of a kind of black oilcloth, and leading Chinese babies dressed in more colors than Joseph's coat-grass-green, black, azure, and rose. In the background several army wagons were filled with officers in uniform and with white-clad American women.

We schoolteachers lost no time when the boat was once tied up at the dock, for it was given out that some trifling repairs were to be made to the boat's engines and that we should sail the next day. We sailed, in 


\section{FROM SAN FRANCISCO TO HONOLULU 25}

point of fact, just ten days later, for the engines had to be taken down to be repaired. As the notice of departure within twenty-four hours was pasted up every day afresh, it held our enthusiasm for sight-seeing at a feverish pitch. 


\section{CHAPTER THREE}

OUR TEN DAYS' SIGHTSEEING

The Fish Market - We are treated to Poi - We visit the Stores - Hawailan Curiosities - The Southern Cross - Our Trip to the Dreadful Pali - The Rescue - The Flowers and Trees of Honolulu - The Mango Tree AND ITS Fruit.

$1 \begin{gathered}\text { Y first impressions of Honolulu were disap- } \\ \text { pointing. I had been, in my childhood, a } \\ \text { fascinated peruser of Mark Twain's "Rough- }\end{gathered}$ ing It," and his picture of Honolulu - or rather my picture formed from his description of it - demanded something novel in foliage and architecture, and a great acreage of tropical vegetation. What we really found was a modern American city with straight streets, close-clipped lawns, and frame houses of various styles of architecture leaning chiefly to the gingerbread, and with a business centre very much like that of a Western town. Only after three or four days did the charm and individuality of Honolulu make themselves felt.

To leave the dock, we had to pass through the fish market, which looked like any other fish market, but seemed to smell worse. When we looked at the fish, however, we almost forgot the odors, for they were as many tinted as a rainbow. Coral red, silver, blue, blue shot with purple, they seemed to tell of sun-kissed 
haunts under wind-ruffled surfaces or of dusky caves within the underworld of branching coral. It is hard to be sentimental about fish, but for the space of two minutes and a half we quite mooned over the beauty fish of Honolulu.

Leaving the market, we came upon a ley woman who wanted to throw a heavy wreath of scented flowers about the neck of each of us at a consideration of twenty cents per capita. She was a fat old woman who used many alluring gestures and grinned coquettishly; but we were adamant to her pleadings, and seeing a street car jingling toward us - one of the bobtailed mule variety - we left her to try her wiles on a fresh group from our boat, and hailed the street car. As we entered, one passenger remarked audibly to another, "I see another transport is in," which speech lowered my spirits fifty degrees. I hate to be so obvious.

Under that nightmare of threatened departure we went flying from place to place. In the first store which we entered we were treated to poi - a dish always offered to the stranger as a mark of hospitality - and partook of it in the national manner; that is, we stuck our forefingers in the poi, and each then sucked her own digit. Poi is made from taro root, and tastes mouldy. It is exceedingly nasty - nobody would want two dips.

The stores were just like those of the United States, and the only commercial novelties which we discovered were chains made of exquisitely tinted shells, which came from somewhere down in the South Seas, and other chains made of coral and of a berry which is hard 
and red and looks like coral. At the Bishop Museum, however, we found an interesting collection of Malaysian curios and products - birds, beasts, fishes, weapons, dress, and domestic utensils. Among the dress exhibits were cloaks made of yellow feathers, quite priceless ( $\mathrm{I}$ forget how many thousand birds were killed to make each cloak); and among the household utensils were wooden bowls inlaid with human teeth. It was a humorous conceit on the part of former $\mathrm{Ha}$ waiian kings thus to compliment a defunct enemy.

There was a dance that night at the Hawaiian Hotel in honor of our passengers, most of whom attended, leaving me almost a solitary passenger aboard. Those happy sinners from Radcliffe went off in their best frocks. I lay in a steamer chair on the afterdeck, scanning the heavens for the Southern Cross. I counted, as nearly as I can remember, about eight arrangements of stars that might have been said to resemble crosses. Not one of them was it, however. Later, I made acquaintance with the Cross, and I must say it has been much overrated by adjective-burdened literature. It does not blaze, and it is lop-sided, and it is not magnificent in the least. It consists of five stars in the form of an irregular diamond, and it is not half so cross-like as the so-called False Cross.

Next morning the military band came down and gave us an hour's concert on the promenade deck. We sat about under the awnings with our novels or our sewing or our attention. At the end they played the "Star Spangled Banner," and we all stood up, the soldiers at attention, hat on breast. One of the passen- 


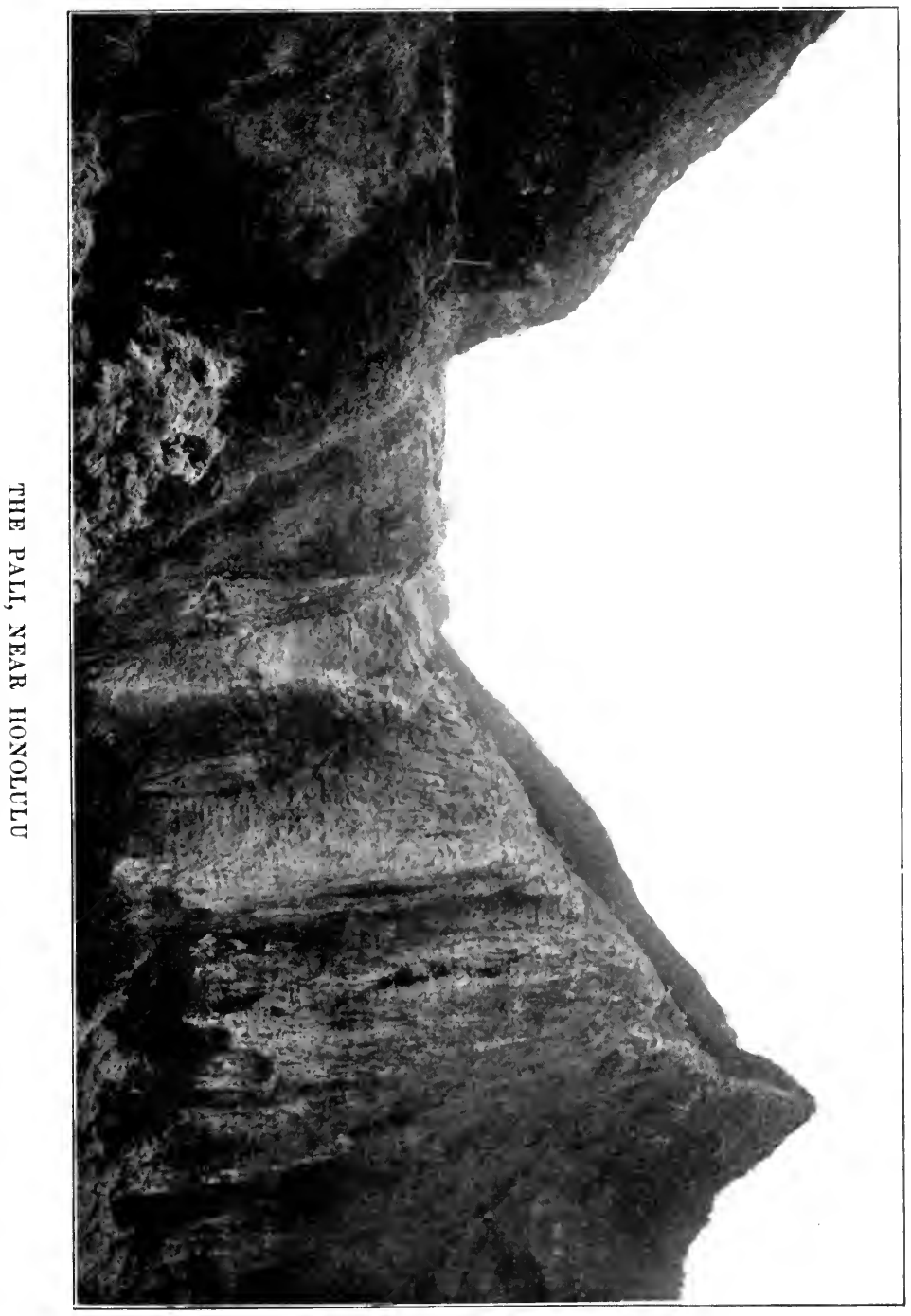



gers refused to take off his hat, so that we had something to gossip about for another hour.

In the afternoon we took a ride up Pacific Heights on the trolley car. Pacific Heights is a residence suburb where the houses are like those on the Peak at Hong Kong, clinging wherever they can get room on the steep sides of the mountain. The view of the city and of the blue harbor dotted with ships was beautiful. In the evening we went to a band concert in Emma Square, and on the third day made our memorable trip to the Pali.

We had been hearing of the Pali ever since we landed. It is a cliff approached by a gorge, whence one of those unpronounceable and unspellable kings once drove his enemies headlong into the sea. We could not miss a scene so provocative of sensations as this, so several of us teachers and an army nurse or two packed ourselves into a wagonette for the journey. We started bright and early, or as near bright and early as is possible when one eats in the second section and the first section sits down to breakfast at eight o'clock.

Our driver was a shrewd, kindly, gray-haired old Yankee, cherishing a true American contempt for all peoples from Asia or the south of Europe. He was conversational when we first started, but his evident desire to do the honors of Honolulu handsomely was chilled by a suggestion from one of the saints that, when we should arrive in the suburbs, he would let down the check-reins. The horses were sturdy brutes, not at all cruelly checked; but the saint could not rise superior to habit. Unfortunately she made the request with 
that blandly patronizing tone which in time becomes second nature to kindergartners. Its insinuating blandness ruffled our Jehu, who opined that his horses were all right, and that he could look after their comfort without any assistance. He did not say anything about old maids, but the air was surcharged with his unexpressed convictions, so that all of our cohort who were over thirty-five were reduced to a kind of abject contrition for having been born, and for having continued to live after it was assured that we were destined to remain incomplete.

We drove through the beautiful Nuuana Avenue with its velvet lawns and magnificent trees, and then wound up the steep valley between the terraced gardens of the mountain-sides. Not a hundred yards away a shower drove by and hung a silver curtain like the gauze one which is used to help out scenic effects in a theatre; and presently another swept over us and drenched us to the skin. Half a dozen times in the upward journey we were well soaked, but we dried out again as soon as the hot sun peeped forth. We did not mind, but tucked our hats under the seats and took our drenchings in good part.

At last we arrived at a point where the road turned abruptly around a sharp peak, the approach to which led through a gorge formed by a second mountain on the left. We could tell that there was a precipice beyond, because we could see the remains of a fence which had been recently broken on the left, or outside, part of the road. The driver stopped some twenty-five or thirty yards outside the gorge, saying that he could 
approach no nearer, as the velocity of the wind in the cleft made it dangerous. Our subsequent experiences led me to doubt his motive in not drawing nearer, and to accredit to him a hateful spirit of revenge.

We alighted in another of those operatic showers, and made our way to the gorge, laughing and dashing the rain drops from our faces. We were not conscious of any particular force of wind, but no sooner were we within those towering walls of rock than a demon power began to tear us into pieces and to urge us in the direction of the broken fence. The first gust terrified us, and with universal feminine assent we clutched at our skirts and screamed.

The next blast sent combs and hairpins flying, drove our wet hair about our faces, and forced us to release our garments, which behaved most shockingly. I saw a kind of recess in the cliffs to the right under an overhanging shelf of rock, and, though it was approached by a mud puddle, made straight for it and in temporary quiet let go my threshing skirts and braided my hair. I could see our driver in the distance, pretending to look after his harness, and indulging in hyæna mirth at the figures we cut. Then, to make matters worse, there came a shout from the hidden road to the right, and, three abreast, a party of young civil engineers from our ship charged round the corner.

Most of our party sat down in their tracks, and a stifled but heartfelt moan escaped from more than one. I waded three inches deeper into the mud puddle and flattened myself against a wall of oozy rock with an utterly unfeminine disregard of consequences. 
The men were of a thoroughly good sort, however, and, ignoring our plight, insisted on helping us round the corner. They said that, once we were out of the gorge and on the other face of the mountain, the strong draught ceased. So each woman took a frenzied grasp of her skirts, and, with an able-bodied man steadying her on each side, made the run and brought up safe on the other side. There did not seem to be much to seenothing but the precipitous face of the cliff towering above us, the road cut out of it, winding steeply down to the right, and the shoulder of the left-hand peak running up into a cloud-swept sky. Below us was a floor of mist, swaying to unfelt airs, heaving, gray, and sad.

Just about this time a Chinaman arrived - one of the beast-of-burden sort - with two immense baskets swung across his shoulders on a bamboo pole. He made three ineffectual efforts to get round the point, but had to fall on his knees each time, as the wind threatened to sweep him too near the cliff. So the philanthropic youths went to his assistance as they had come to ours, and piloted him safely round the bend. We became so much interested in this operation and in the Chinaman's efforts to express his thanks that we quite forgot our disappointment at the Pali's unkind behavior. A sudden gleam of sunshine recalled us. The clouds which had been dripping down upon us were rent apart to reveal a long streamer of blue, and to give passage to a shaft of sunlight which drove resistlessly through the mist floor. The fog parted shudderingly, silently, and for a moment we looked 
down into a beautiful valley, green and with a thousand other tints and shades, and set in a great inward curve, beyond which the sea raced up in frothy billows to the clean white sands. Far beneath us as it was, we could detect the flashes on wet foliage; indeed, I could think of nothing but a cup of emerald rimmed with sapphire and studded with brilliants. For an all too brief space it quivered and shimmered under the sunburst, and then the mist floor closed relentlessly, the heavens grayed again, and another downpour set in.

We waited long, but the Pali declined to be wooed into sight again, nor am I certain that we were the losers thereby. The whole effect was so brief and vivid that our pleasure in it was greatly intensified. Longer vision might have brought out details which we missed, but it would have converted into the memory of a beautiful scene that which has remained a peep into fairyland.

Our return through the gorge was accompanied by all the original drawbacks. Our driver had released the check-reins of the horses, but he ostentatiously checked them up again as we appeared. He had entirely recovered his good humor, and contemplated our dishevelled appearance with secret glee. The Pali has its good features, but it must be admitted there are drawbacks.

Among the military people aboard there was a lady of uncertain age, and of a mistaken conception of what was becoming to her fading charms. She was gaunt, and leathery of skin, and she wore "baby necks" and elbow sleeves, and affected childish simplicity and 
perennial youth. On our first night out of Honolulu I happened to come around the corner of the promenade deck in time to observe one of the men passengers contemplating this lady, who stood at some distance from him, attired in a rather décolleté frock. The man's attitude was a modified edition of that of the Colossus of Rhodes. He steadied a cigarette between his lips with the third and fourth fingers of his left hand, while his right hand was thrust into his trousers pocket. A peculiar expression lingered on his countenance a kind of struggle between a painful memory and a judicial estimate. He was so absorbed in his musings that he did not notice me, and he spoke aloud.

"I knew she was thin," he said, "but even with her low-necked dresses, I did not think that it was as bad as it is."

I beat a retreat without attracting his attention, but I understood him, for I had seen him on the back seat of an army ambulance in the clutches of the perennially youthful lady, starting for the Pali.

We left Honolulu with the modified regret which always must be entertained when other lands are beckoning. The native custom of adorning departing friends with wreaths of flowers was followed, and some of our army belles were almost weighed down with circlets of blossoms cast over their heads by admiring officers of Honolulu. Once clear of the dock and out of eye range, they shamelessly cast these tokens away, and the deck stewards gathered up the perfumed heaps and threw them overboard. The favorite flowers used in these ley, or wreaths, were the creamy white blossoms 


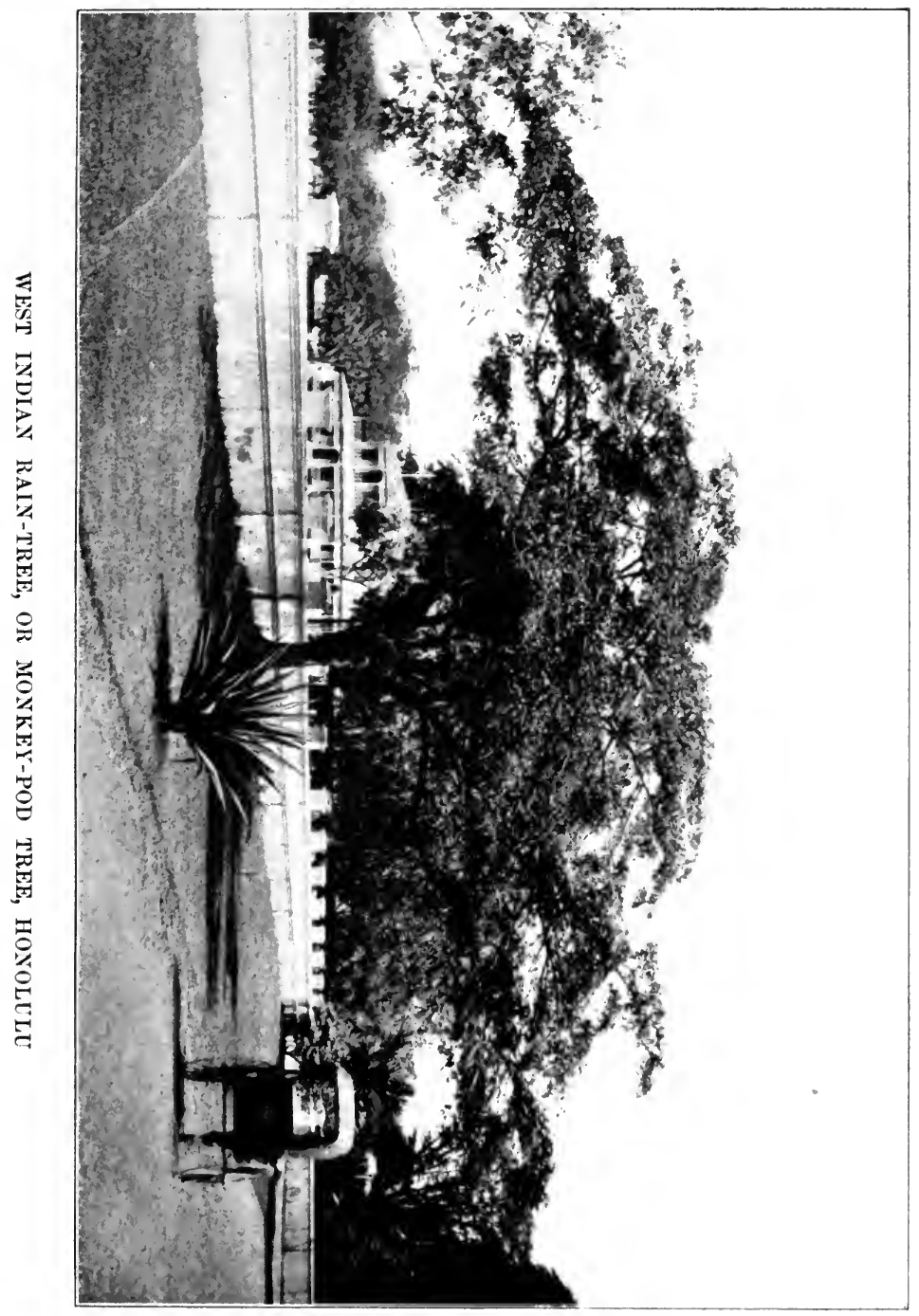



with the golden centre from which the perfume frangipani is extracted. This flower is known in the Philippines as calachuchi. There were also some of the yellow, bell-shaped flowers called "campanilo," and a variety of the hibiscus which we learned to call "coral hibiscus," but which in the Philippines is known as arana, or spider.

The flowers of Honolulu and Manila seem very much alike. In neither place is there a wide variety of garden flowers, but there is an abundance of flowering shrubs and trees.

One quite common plant is the bougainvillæa, which climbs over trellises or trees, and covers them with its mass of magenta blossoms. The scarlet hibiscus, either single or double, and the so-called coral hibiscus grow profusely and attain the size of a large lilac bush. There is another bush which produces clusters of tiny, starlike flowers in either white or pink. It is called in the Philippines "santan," but I do not know its name in Honolulu.

Catholic missionaries were instrumental in introducing into the Hawaiian Islands a tree of hardy and beautiful foliage which has thrived and now covers a great part of the mountain slopes. This is the algoroda tree, the drooping foliage of which is suggestive of a weeping willow. Then there is the beautiful West Indian rain-tree, which the Honolulu people call the monkey-pod tree, and which in the Philippines is miscalled acacia. Its broad branches extend outward in graceful curves, the foliage is thick but not crowded, and it is an ideal shade tree, apart from the charm of its blossoms of purplish pink. 
The fire-tree and the mango are two others which are a joy to all true lovers of trees. The fire-tree is deciduous, and loses its leaves in December. In April or May, before the leaves come back, it bursts into bloom in great bunches of scarlet about the size of the flower mass of the catalpa tree. The bark is white, and as the tree attains the size of a large maple, the sight of this enormous bouquet is something to be remembered. When the leaves come back, the foliage is thick, and the general appearance of the tree is like that of a locust.

Among tropical trees, however, the most beautiful is the mango. Its shape is that of a sharply domed bowl. The leaves are glossy and thickly clustered. It is distinguishable at a long distance by its dignity and grace. But the mass of its foliage is a drawback, inasmuch as few trunks can sustain the weight; and one sees everywhere the great trunk prostrate, the roots clinging to the soil, and the upper branches doing their best to overcome the disadvantages of a recumbent position.

We ate our first mangoes in Honolulu, and were highly disgusted with them, assenting without murmur to the statement that the liking of mangoes is an acquired taste. I had a doubt, to which I did not give utterance, of ever acquiring the taste, but may as well admit that I did acquire it in time. The only American fruit resembling a mango in appearance is the western pawpaw. The mango is considerably larger than the pawpaw, and not identical in shape, though very like it in smooth, golden outer covering. When the mango 


\section{OUR TEN DAYS' SIGHTSEEING}

is ripe, its meat is yellow and pulpy and quite fibrous near the stone, to which it adheres as does a clingstone peach. It tastes like a combination of apple, peach, pear, and apricot with a final merger of turpentine. At first the turpentine flavor so far dominates all others that the consumer is moved to throw his fruit into the nearest ditch; but in time it diminishes, and one comes to agree with the tropical races in the opinion that the mango is the king of all fruits. 


\section{CHAPTER FOUR}

FROM HONOLULU TO MANILA

Voyaging over the Tropical Seas - We touch at Guam, or Guahan, One of the Ladrone Islands - Our First Sight of the Philippines - Manila, "a Mass of Towers, Domes, and White-Painted Iron Roofs Peeping out of Green " Dispersion of the Passengers.

TROM Honolulu to Guam we crept straight across in the equatorial current, blistering hot by day, a white heat haze dimming the horizon, and an oily sea, not blue, but purple, running in swells so long and gentle that one could perceive them only by watching the rail change its angle. Once we saw a whale spout; several times sharks followed us, attracted by the morning's output of garbage; and at intervals flying fish sallied out in sprays of silver. Once or twice we passed through schools of skate, which, when they came under our lee, had a curiously dazzling and phosphorescent appearance. One of the civil engineers aboard called them phosphorescent skate, but I had my doubts, for I noticed that bits of paper cast overboard would assume the same opalescent tints when three or four feet down in the water.

We had also the full moon, leaving a great shining pathway in our wake at night, and flooding us with unreal splendor. The pale stars swung up and down as the Buford slipped over each wave, and little ripples 
of breeze cooled the weather side of the ship. By this time we were a thoroughly assorted company. The afterdeck was yielded to flirtatious married ladies whose husbands were awaiting them in Manila, while we sobersides and the family groups gathered under the awnings. We sang no more; but the indefatigable cornetist on the troop deck still entertained his fellows, while occasionally a second steward stole out with a mandolin, and struggled with the intermezzo from "Cavalleria." We did not run out of talk, however, and the days went by all too swiftly.

Of Guam I can only say that it struck me as the most desolate spot I had ever seen. It stays in my memory as a long peninsula, or spit of land, running out into the sea, with a ten or twelve-foot bank above, fringed with ragged cocoanut trees. Back of this the land rose gradually into low hills. There was a road leading to the town some eight miles inland, and fourmule ambulances dashed up and down this. We had to anchor three miles off shore on account of coral reefs. We had commissary stores to land, and our navigator captain lost his temper, because the only available lighter in Guam was smashed by a falling bundle of pig iron the first thing. For a while the outlook for fresh provisions in Guam was a sorry one, for our captain vowed by all his saints that he would up anchor and away at four o'clock. The glass indicated a change of weather, and he was unwilling to risk his ship in the labyrinth of coral reefs that encircles the island. Fortunately a German tramp whaler dropped into harbor at this point for water, 
and some boats were obtained from her - though I could never see why, for we had plenty of our own. The unloading process went on briskly, and toward noon the U. S. gunboat Yorktown came in to pay a call; thus there were actually three vessels at one time in the harbor of Guam.

Such a repletion of visitors had never been known there. The four-mule wagons seemed crazed with excitement. The enthusiasm even spread to the natives, who hung about in dug-outs, offering to sell us cocoanuts, pineapples, and green corn. Our captain kept his word, for at four o'clock we swung about and left Guam behind us. Our passenger list was richer by several political prisoners who had been in exile and were returning to their native land - whether for trial or for freedom, I have no knowledge.

Some five or six days later, it was rumored that we should pick up the light on the southeast coast of Luzon about midnight, and most of us stayed up to see it. We also indulged in the celebration without which few passenger ships can complete a long voyage. We had a paper and it was read, after which ceremonial the ship's officers invited us to partake of sandwiches and lemonade in the dining-room. The refreshments were considerably better than the paper, which was neither wise nor witty, but abounded in those commonplace personalities to which the imagination of amateur editors usually soars.

About 2 A. M., when yawns were growing harder and harder to conceal, the light made its appearance. I counted three flashes and went below. 


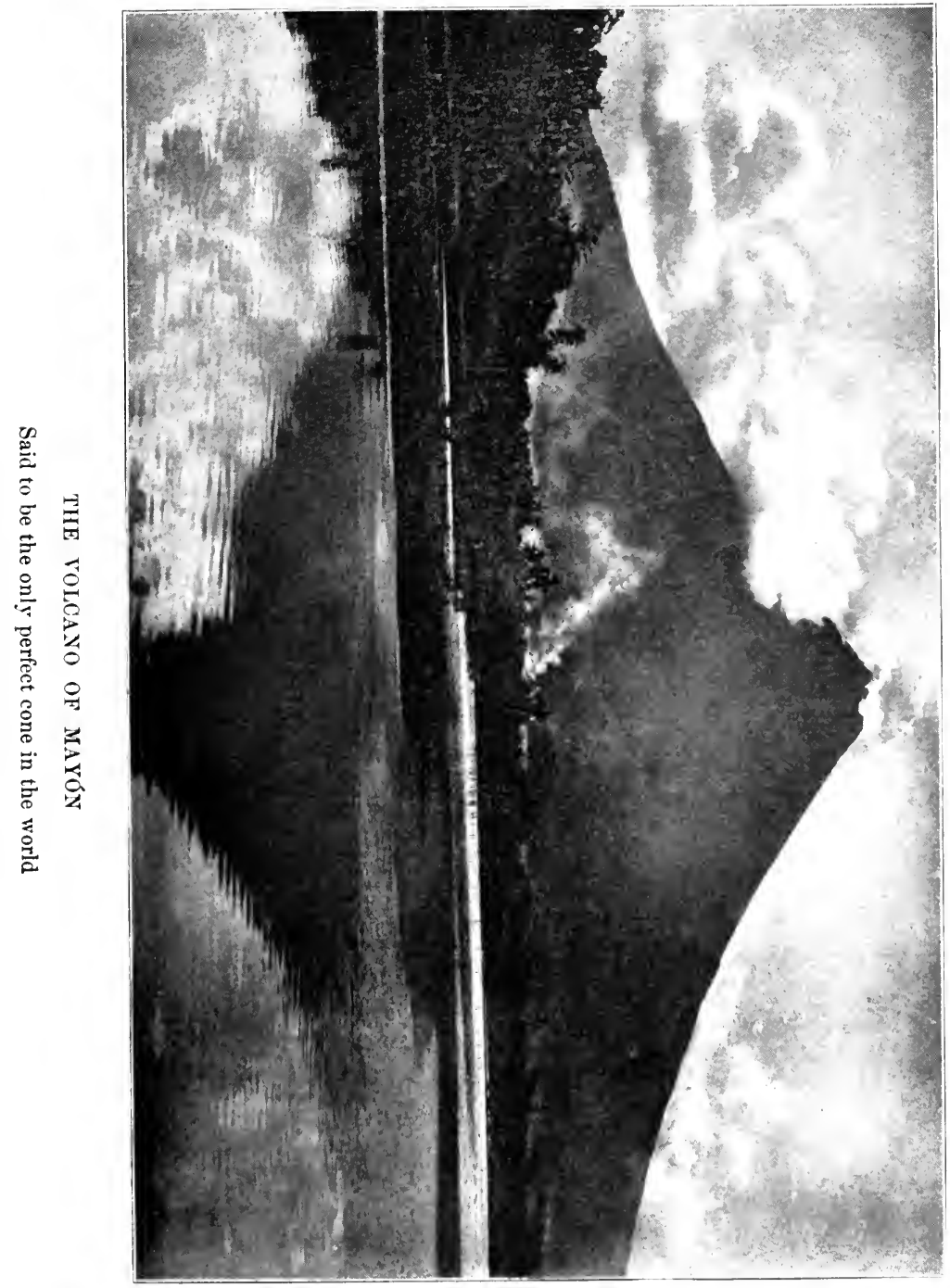



Next morning, we were hugging the coast of Albay abreast the volcano of Mayón, said to be the most perfect volcanic cone in the world. It seems to rise straight from the sea; with its perfectly sloping sides and a summit wreathed in delicate vapors, it is worthy of the pride with which it is regarded by the Filipinos.

Then we entered the Strait of San Bernardino, between Luzon and Samar, and passed for a day through a region of isles. The sea was glassy save when a school of porpoises tore it apart in their pursuit of the flying fish. On its deep sapphire the islands seemed to float, sometimes a mere pinnacle of rock, sometimes a cone-shaped peak timbered down to the beach where the surf fell over. Toward evening, when the breeze freshened slightly, we seemed almost to brush the sides of some of these islets, and they invited us with sparkling pools and coves, with beaches over which the sea wimpled, and with grassy hillsides running out into promontories above cliffs of volcanic rock. Thatched villages nestled in the clefts of the larger islands, or a fleet of paraos might be drawn up in a curving bay. And, yonder in the golden west, shimmering, dancing, in rosy-tinted splendor, more islands beckoned us to the final glory of a matchless day - clouds heaped on clouds, outlined in thin threads of gold, and drawing, in broad shafts of smoky flame, the vapors of an opal sea. At that time I had not seen the famous Inland Sea of Japan, but I have since passed through it twice, and feel that in beauty the Strait of San Bernardino has little to yield to her far-famed neighbor. 
Next day we crept up the coast of Batangas, and when I came on deck the second morning they told me that the island on our left was Corregidor, and that Manila was three hours' sail ahead. It was of no use going into a trance and coming up in imagination with Dewey, because he did not come our way. The entrance to Manila Bay is rather narrow, and Corregidor lies a little to one side in it like a stone blocking a doorway. The passage on the left entering the bay is called Boca Chica, or Little Mouth; that to the right is called Boca Grande, or Big Mouth. Dewey entered by the Boca Chica, and we were in Boca Grande.

By and by a cluster of roofs, church towers, docks, and arsenals took form against the sea. A little later we could discern the hulks of the Spanish fleet scattered in the water, and several of our own fighting craft at anchor. This was Cavite. There, too, around a great curve of eight or nine miles, lay Manila, a mass of towers, domes, and white-painted iron roofs peeping out of green. Behind loomed the background of mountains, without which no Filipino landscape is ever complete.

By eleven o'clock we had dropped anchor and the long voyage was over. Counting our ten days in Honolulu, we lacked but three of the forty days and forty nights in which the pilgrims fasted in the wilds. It would be injustice to the Buford's well-filled larder, however, to intimate that we fasted. Our food was good, barring the ice cream, which the chef had a weakness for flavoring with rose water.

The first launch that came out after the doctor's 


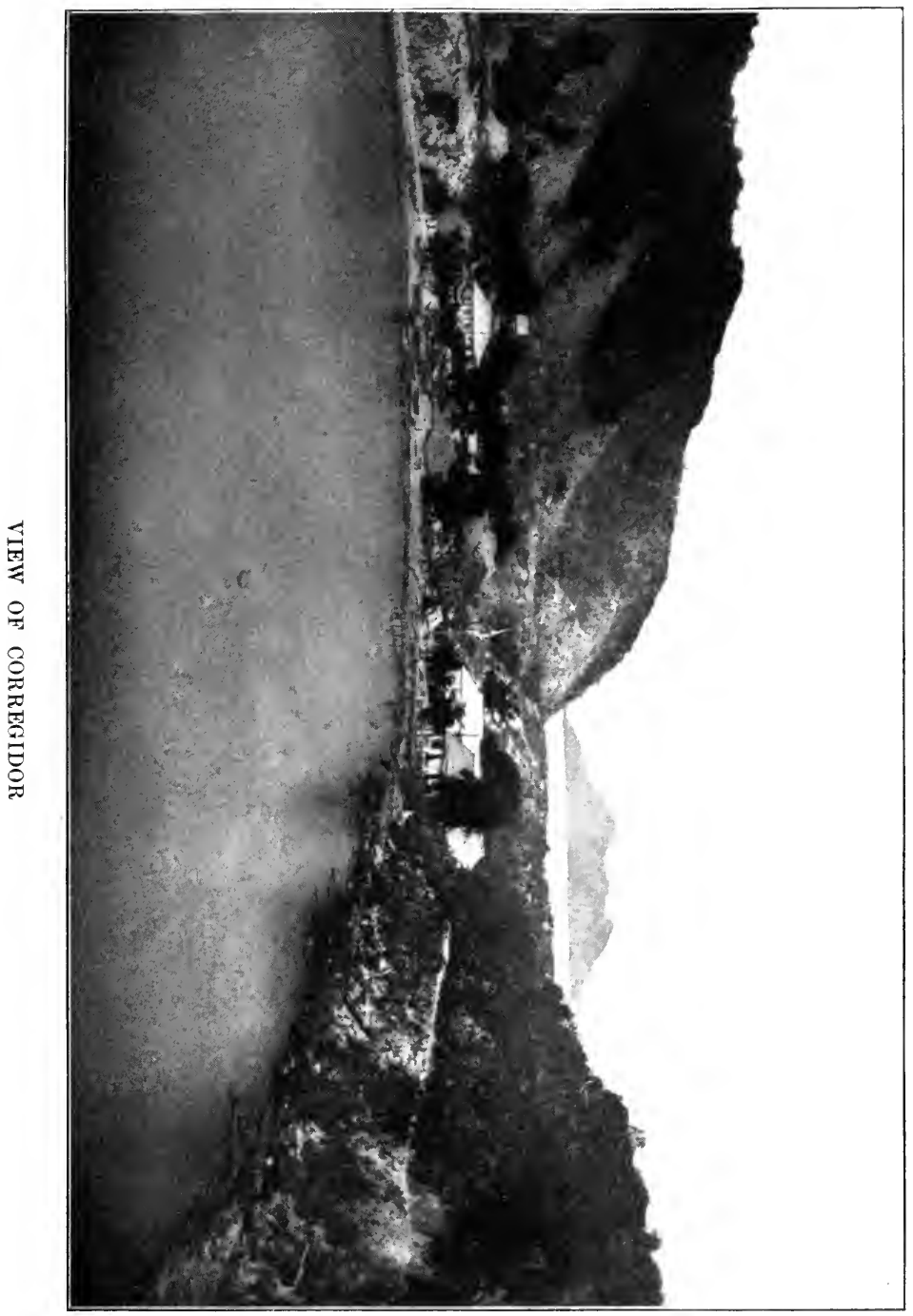



brought a messenger from the Educational Department with orders to us teachers to remain aboard till next day, when a special launch would be sent for us. So all day we watched our friends go down over the side, and waved farewells to them, and made engagements to meet on the Luneta. The launches and lighters and cascos swarmed round us, the cargo derricks groaned and screeched, the soldiers gathered up knapsack and canteen and marched solemnly down the ladder. Vessels steamed past us or anchored near us, while we hung over the rail, gazing at Manila, so near and yet so far. After dinner we betook ourselves to the empty afterdeck and stared down the long promenade - alas! resembling the piazza of a very empty hotel! - and peopled it with the ghosts of those who late had sat there. They had gone out of our lives after a few brief days of idleness, but they would take up, as we should, the work of building a nation in a strange land and out of a reluctant people. Some were fated to die of wounds, and some were stricken with the pestilence. Most of them are still living, moving from army post to army post. Some are still toiling in the remotenesses of mountain villages; others are dashing about Manila in the midst of its feverish society. Some have gone to swell the American colonies in Asiatic coast towns. A few have shaken the dust of the Philippines forever from their feet, and are seeking fame in the home land and wooing fortune in the traffic of great cities or in peaceful rural life. Some, perhaps, may read these lines, and, reading, pause to give a tender thought to the land which 
most Americans revile while they are in it, but which they sentimentally regret when they have left it.

Eight long years have slipped by since that night, and in that time a passing-bell has tolled for the Philippines which we found then. Who shall say for many a year whether the change be for better or for worse? But the change has come, and for the sake of a glamour which overlay the quaint and moribund civilization of the Philippines of that day I have chronicled in this volume my singularly unadventurous experiences.

The afterdeck was empty, and the promenade was the haunt of ghosts, but across the circle of gloom we could see a long oval of arc lights with thousands of little glow-worms beneath, which we knew were not glow-worms at all, but carriage lamps dashing round the band stand; and as if he divined our sentimental musings, the second steward took heart and not only played but sang his favorite air from "Cavalleria." 


\section{CHAPTER FIVE}

\section{OUR FIRST FEW DAYS IN THE CITY}

The Pasig River, with its Swarm of House-boats - Throdgh Manila into the Walled City - Our First Meal - A Walk and a Drive in Manila - The Admirable Policemen - We superintend the Preparation of Quarters for Additional Teachers - That Artful Radcliffe Girl.

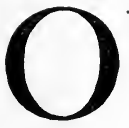

UR guide from the Educational Department appeared about eleven o'clock the next day, which happened to be Sunday. We and our trunks were bundled into a launch, and we left the Buford forever.

We were familiar with the magazine illustrations of the Pasig long before our pedagogic invasion of Manila, but we were unprepared for the additional charm lent to these familiar views by the play of color. The shipping was as we had imagined it - large black and gray coasters in the Hong-Kong and inter-island trade, a host of dirty little vapors (steamers) of light tonnage, and the innumerable cascos and bancas. The bancas are dug-out canoes, each paddled by a single oarsman. The casco is a lumbering hull covered aver in the centre with a mat of plaited bamboo, which makes a cave-like cabin and a living room for the owner's family. Children are born, grow up, become engaged, marry, give birth to more children - in short, 
spend their lives on these boats with a dog, a goat, and ten or twelve lusty gamecocks for society.

The cascos lie along the bank of the river ten deep; every time a coasting steamer wants to get out, she runs afoul of them in some way, and there is a pretty iness. It always seems to turn out happily, but the excitement is great while it lasts, and it is apparently never dulled by repetition.

We swept up the Pasig with Fort Santiago and the ancient city wall on the right; and, on the left, warehouses, or bodegas, a customhouse with a gilded dome, and everywhere the faded creams and pinks of painted wooden buildings. Some of the roofs were of corrugated iron, but more were of old red Chinese tiles, with ferns and other waving green things sprouting in the cracks. The wall was completely hidden with vegetation.

We landed at the customhouse, left our trunks for inspection, and entered gig-like vehicles which were drawn by diminutive ponies and were called carromatos. Two of us were a tight fit, and, as I am stout, I was afraid to lean back lest I should drag the pony upon his hind legs, and our entrance into Manila should become an unseemly one. The carromato wheels were iron-tired, and jolted - well, like Manila street carromatos of that day. Since then a modification of the carromato and of another vehicle called calesin has been evolved. The modern conveyance has rubber tires and a better angle of adjustment, and the rat-like pony will dash about with it all day in good spirits.

We rattled up a street which $I$ have since learned 


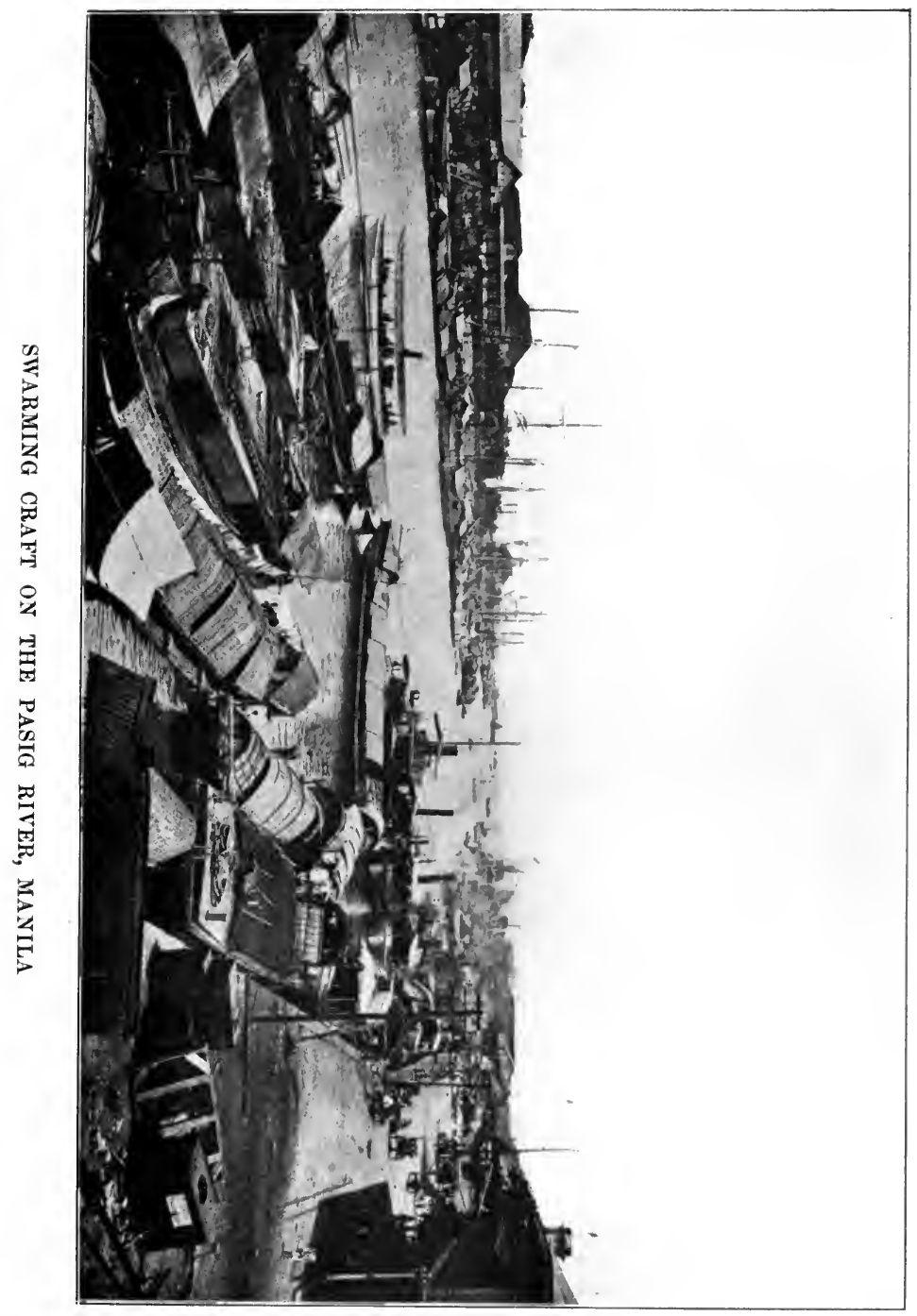



is called San Fernando, and which looks like the famous Chinatown of San Francisco, only more so. We passed over a canal spanned by a quaint stone bridge, arriving in front of the Binondo Church just as the noon hour struck. Instantly there burst out such a clamor of bells as we had never before heard - big bells and little bells, brass bells and broken bells - and brass bands lurking in unknown spots seemed to be assisting. I do not know whether the Filipinos were originally fond of noise or whether the Spaniards taught them to be so. At any rate, they both love it equally well now, and whenever the chance falls, the bells and the bands are ranged in opposition, yet bent to a common end.

The Bridge of Spain is approached from the Binondo side by almost the only steep grade to be found in Manila. I was leaning as far forward as I could, figuring upon the possible strain to be withstood by the frayed rope end which lay between us and a backward somersault, when my ears were assailed by an uncanny sound, half grunt, half moan. For an instant I thought it was the wretched pony moved to protest by the grade and my oppressive weight. But the pony. was breasting the steep most gallantly, all things considered. The miserable sound was repeated a second later, just as our little four-footed friend struck the level, and I discovered that it was my driver's appeal to his steed. It is a sound to move the pity of more than a horse; until you are thoroughly accustomed to it it leaves you under the apprehension that the cochero has been stricken with the plague. This habit 
of grunting at horses seems to be disappearing at the present time, the haughty customs of livery carromatos perhaps being responsible. Also English is spreading. Apart from swear words, which appear to fill a long-felt want for something emphatic, there are at least three phrases which every Filipino who has to do with horses seems to have made a part of his vocabulary. They are "Back!" "Whoa, boy!" and "Git up!" Your cochero may groan at your horse or whine at it, but when the need arises he can draw upon that much of English.

We jolted over the Bridge of Spain and through a masked gate into the walled city, with the wall on our left, and the high bricked boundaries of churches and conventos on the right, till we arrived at a low, square frame structure, with the words "Escuela $\mathrm{Mu}$ nicipal" above its portals. In Spanish times it was the training-school for girls, and here temporary accommodation had been provided for us. We crossed a hall and a court where ferns and palms were growing, and were ushered into a room containing a number of four-poster beds. We were to obtain our food at a neighboring restaurant, whither we soon set out under guidance. The street was narrow, and all the houses had projecting second floors which overhung the sidewalk. Box-like shops on the ground floor were filled with cheap, unattractive-looking European wares, with here and there a restaurant displaying its viands and attracting flies. We recognized the bananas and occasionally a pineapple, but the other fruits were new to us - lanzones in white, fuzzy clusters like 


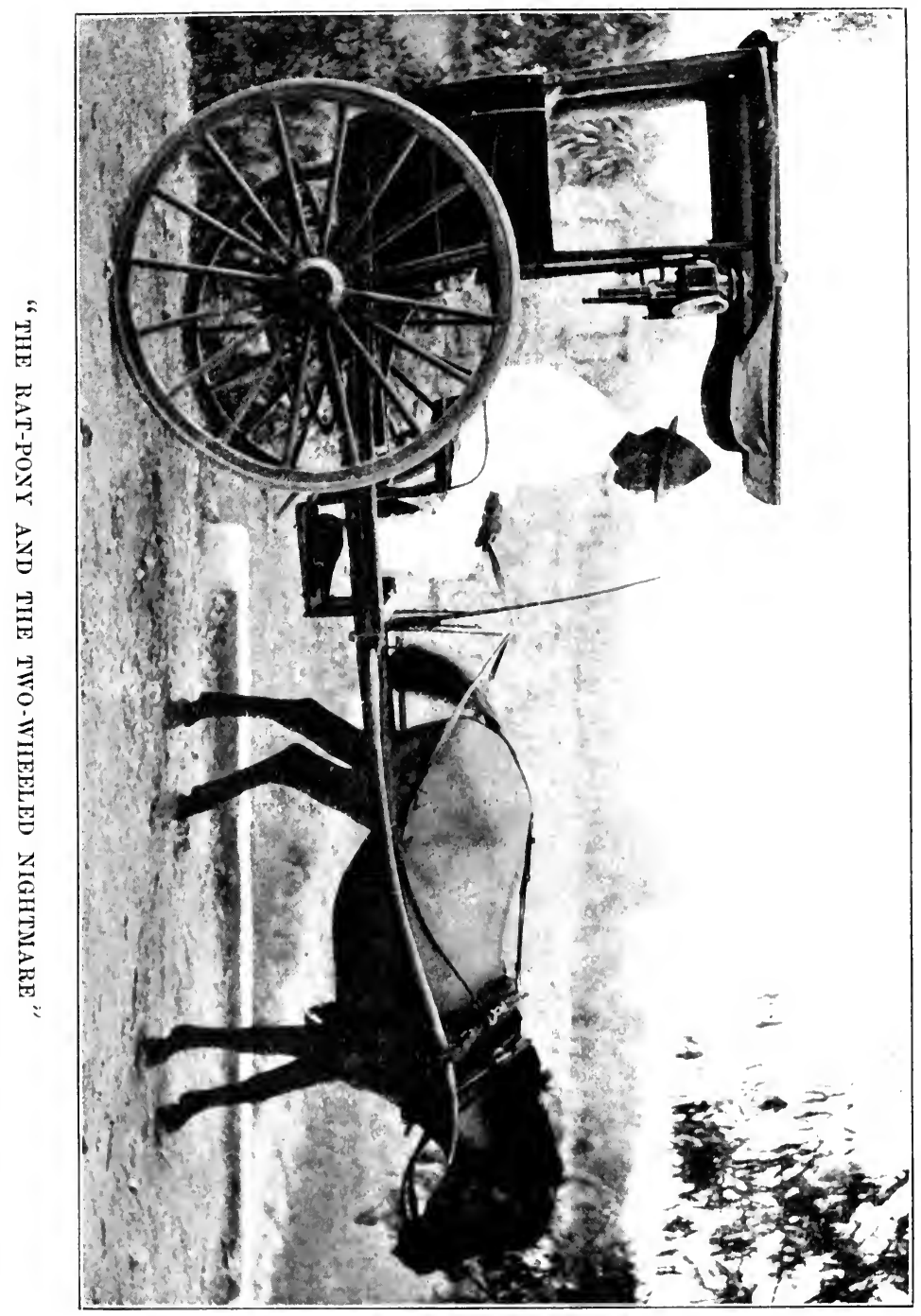



giant grapes; the chico, a little brown fruit that tastes like baked apple flavored with caramel; and the atis, which most natives prize as a delicacy, but which few Americans ever learn to like.

We had been introduced to the alligator pear, the papaya, and the mango at Honolulu, but we were still expecting strange and wonderful gastronomic treats in our first Philippine meal.

We entered a stone-flagged lower hall where several shrouded carriages would have betrayed the use to which it was put had not a stable odor first betrayed it. Thence we passed up a staircase, broad and shallow, which at the top entered a long, high-ceiled room, evidently a salon in days past. It had fallen to baser uses, however, and now served as dining-room. One side gave on the court, and another on an azotea where were tropical plants and a monkey. It was a bare, cheerless apartment, hot in the unshaded light of a tropical noonday. The tables were not alluring. The waiters were American negroes. A Filipino youth, dressed in a white suit, and wearing his black hair in a pompadour, was beating out "rag time" at a cracked old piano.

"Easy is the descent into Avernus!" But there was consolation in the monkey and the azotea, though we could neither pet the one nor walk on the other. However, we were the sort of people not easily disconcerted by trifles, and we sat down still expectant.

The vegetables were canned, the milk was canned, the butter was canned, and the inference was plain that it had made the trip from Holland in a sailing 
vessel going around Cape Horn or the Cape of Good Hope. As for the fruits, there was but one fruit, a little acid banana full of tiny black seeds. With guava jelly it was served for dessert. Our landlord, an enterprising American, had been so far influenced by local custom that he had come to regard these two delicacies as a never inappropriate dessert. So long as we continued to "chow" with him, so long appeared the acid, flavorless banana and the gummy, sticky jelly.

In justice to Manila it must be said, however, that such conditions have long since been outlived. Good food and well-served American tables are plentiful enough in Manila to-day. The cold-storage depots provide meats and butter at prices as good as those of the home land, if not better. Manila is no longer congested with the population, both native and American, which centred there in war times. There is not the variety of fruits to be found in the United States, but there is no lack of wholesome, appetizing food.

We returned to the Escuela Municipal, and, after a nap, dressed and went out for a walk. The narrow streets with overhanging second stories; the open windows with gayly dressed girls leaning out to talk with amorous swains on the pavement below; the swarming vehicles with coachmen shouting "Ta-beh"; and the frailes (friars) - tall, thin, bearded frailes in brown garments and sandals, or rosy, clean-shaven, plump frailes in flapping white robes - all made a novel scene to our untravelled eyes. Mounting a flight of moss-grown steps, we found ourselves on top of the wall, whence we could look across the 
moat to the beautiful avenue, called, on the maps of Manila, the Paseo de Las Aguadas, but familiarly known as the Bagumbayan. West India rain-trees spread their broad branches over it, and all Manila seemed to be walking, riding, or driving upon it. It was the hour when everybody turns his face Luneta-ward. Seized with the longing, we too sent for a carriage.

Our coachman wore no uniform, but was resplendent in a fresh-laundered white muslin shirt which he wore outside his drill trousers. He carried us through the walled city and out by a masked gate to a drive called the Malecon, a broad, smooth roadway lined with cocoanut palms. On the bay side the waters dashed against the sea wall just as Lake Michigan does on the Lake Shore Drive in Chicago. But the view across the bay at Manila is infinitely more beautiful than that at Chicago. To the left stretches a noble curve of beach, ending with the spires and roofs of Cavite and a purple line of plateau, drawn boldly across the sky. In front there is the wide expanse of water, dotted with every variety of craft, with a lonely mountain, rising apparently straight from the sea, bulking itself in the foreground a little to the left. The mountain is in reality Mt. Marivales, the headland which forms the north entrance to Manila Bay, but it is so much higher than the sierra which runs back from it that it manages to convey a splendid picture of isolation. The sun falls behind Marivales, painting a flaming background for mountains and sea. When that smouldering curtain of night has dropped, and the sea lies glooming, and the ships of all nations 
swing on their anchor chains, there are few lovelier spots than the Luneta. The wind comes soft as velvet, the surf croons a lullaby, and the little toy horses and toy victorias spin up and down between the palms, settling at last around the turf oval which surrounds the bandstand.

Here are soldiers in clean khaki on the benches; officers of the army and navy in snow-white uniforms; Chinamen in robes of purple or blue silk, smoking in their victorias; Japanese and Chinese nursemaids in their native costumes watching their charges at play on the grass; bareheaded American women; blackhaired Spanish beauties; and native women with their long, graceful necks rising from the stiff folds of azure or rose-colored kerchiefs. American officers tower by on their big horses, or American women in white drill habits. There are droves of American children on native ponies, the girls riding astride, their fat little legs in pink or blue stockings bobbing against the ponies' sides. There are boys' schools out for a walk in charge of shovel-hatted priests. There are demure processions of maidens from the colegios, sedately promenading two and two, with black-robed madres vainly endeavoring to intercept surreptitious glances and remarks. There are groups of Hindoos in turbans. There are Englishmen with the inevitable walking-sticks. There are friars apparently of all created orders, and there is the Manila policeman.

As I recall those early impressions, I think the awe and respect for the Manila police was quite the strongest of all. They were the picked men of the army of 


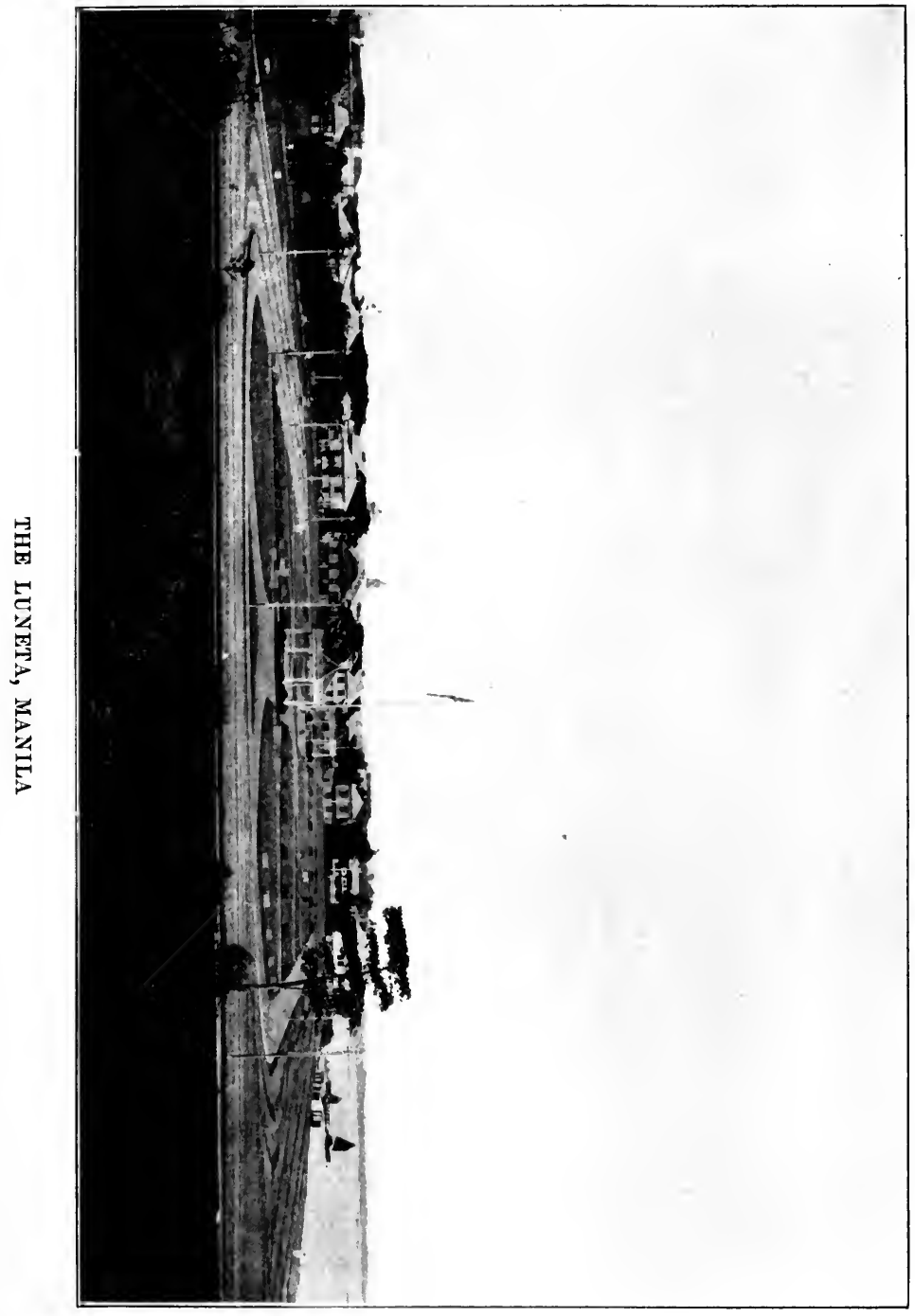



invasion, non-commissioned officers who could show an honorable discharge. Size must have been taken into consideration in selecting them, for I do not remember seeing one who was of less than admirable proportions. Soldierly training was in every movement. There was none of the loafing stride characteristic of the professional roundsman. They wore gray-green khaki, tan shoes, tan leather leggings, and the military cap; and a better set up, smarter, abler body of law preservers it would be difficult to find. The "machinery of politics" had not affected them, the instinct of the soldier to do his duty was strong in them, and they would have arrested Governor William H. Taft himself as gleefully as they would have arrested a common Chinaman, had the Governor offered sufficient provocation.

We enjoyed that first night's entertainment on the Luneta as do all who come to Manila, and I must confess that time has not staled it for me. It is cosmopolitan and yet typically Philippine. Since that day the fine Constabulary Band has come into existence, and the music has grown to be more than a mere feature of the whole scene. The concert would be well worth an admission fee and an hour's confinement in a stuffy hall. Enjoyed in delightful pure air with a background of wonderful beauty, it is a veritable treat.

On the following day we had our interview with the Superintendent of Public Instruction. $\mathrm{He}$ informed us that in the course of a week the transport Thomas would arrive, carrying some five hundred or 
more pedagogues. He suggested that, as we were then drawing full pay, we might reimburse the Government by making ourselves useful at the Exposition Building, which was being put in order to receive them.

So to the Exposition Building we betook ourselves, and for several days made herculean efforts to induce the native boys and Chinese who were supposed to clean it up to do so properly. We also helped to put up cots and to hang mosquito nettings, and at night we lay and listened to the most vociferous concert of bull frogs, debutante frogs, tree toads, katydids, locusts, and iku lizards that ever murdered the sleep of the just. We also left an open box of candy on the table of the dormitory which we had preëmpted, starting therewith another such frantic migration in the ant world as in the human world once poured into the Klondike. They came on all trails from far and near. They invaded our beds, and when the sweets gave out, took bites out of us as the next best delicacy.

Manila seemed to be more or less excited over the new army of invasion, the local papers teeming with jokes about pretty schoolma'ams and susceptible exiles. The teachers were to land at the Anda Monument at the Pasig end of the Malecon Drive, and thence were to be conveyed to the Exposition Building in army ambulances and Doherty wagons which the military had put at the disposal of the Civil Government.

Owing to the fact that I was appointed a sort of matron to the women's dormitory, and had to be on hand to assign the ladies to their cots and to register 
them, I did not go down to the Anda Monument to see the disembarkation. Plenty of people who might have pleaded less legitimate interest in the pedagogues than I had, were there, however. By half-past ten the first wagon-load had arrived at the Exposition Building in a heavy shower, and from then till early noon they continued to pour in. On the whole, they were up to a high standard - a considerably higher standard than has since been maintained in the Educational Department. The women were a shade in advance of the men.

Both men and women accepted their rough quarters with few complaints. Nearly all were obliging and ready to do their best to make up for the deficiencies in bell boys and other hotel accommodations. We arranged a plan whereby twelve women teachers were to be on duty each day, - a division of four for morning, afternoon, and evening, respectively. The number of each woman's cot and room was placed after her name, and one teacher acted as clerk while the others played bell boy and hunted for those in demand.

And they were overworked! By five o'clock in the afternoon the parlor of the Exposition Building looked like a hotel lobby in a town where a presidential nominating convention is in session. To begin with, there were the one hundred and sixty schoolma'ams. Then the men teachers, who had been assigned to the old nipa artillery barracks, found the women's parlors a pleasant place in which to spend an odd half-hour, and made themselves at home there. In addition, each woman seemed to have some acquaintance among the 
military or civil people of Manila; and officers in white and gold, and women in the creams, blues, and pinks of Filipino jusi thronged the rooms till one could hardly get through the press. Victorias and carromatos outside were crowded as carriages are about the theatres on grand opera nights at home.

It would have been difficult in all that crowd to say who was there with good and sufficient reason. Many a man drifted in and out with the hope of picking up acquaintances, and doubtless some were successful.

I was at the desk one day, doing duty for a teacher who was sick, when two forlorn but kind-looking young men approached and asked if I could tell them the names of any of the teachers from Michigan. We had a list of names arranged by States, and I at once handed this over. They pored over this long and sorrowfully. Then one heaved a sigh, and one took me into his confidence. They were from Michigan, and they had hoped to find, one or the other, an acquaintance on the list. The eagerness of this hope had even led them to bring a carriage with the ulterior motive of doing the honors of Manila if their search proved successful. Their disappointment was so heavy, and they were so naïvely unconscious of anything strained in the situation, that my sympathy was honest and open. But when they suggested that I introduce them to some of the women teachers from Michigan, and I declined the responsibility as gently as I could, the frigidity of their injured pride made me momentarily abject. They drifted away and hung about with ex- 
pectancy printed on their faces - that and a mingled hate and defiance of the glittering uniforms which quite absorbed all feminine attention and left their civilian dulness completely overshadowed.

One of the Radcliffe maidens had an experience which goes far to show that higher culture does not eradicate the talent for duplicity for which the female sex has long been noted, and which illustrates a happy faculty of getting out of a disagreeable situation. It also illustrates a singular mingling of unsophistication and astuteness, which may be a result of collegiate training.

One of the chief difficulties which beset us was the matter of transportation. In those days there was no street-car system - or at least the apology for one which they had was not patronized by Europeans. The heat and the frequent showers made a conveyance an absolute necessity. The livery stables were not fully equal to the demand upon them, and, in addition, there was no telephone at the Exposition Building. As a consequence, we had to rely largely on street carromatos. We had a force of small boys, clad in what Mr. Kipling calls "inadequate" shirts, whose business it was to go forth in response to the command, "Busca carromato," and to return not till accompanied by the two-wheeled nightmare and the Lilliputian pony.

On the morning on which we drew our travel-pay checks, one of the Radcliffe girls was most eager to get down town before the bank closed. The shops of Manila had been altogether too alluring for the very 
small balance which remained in her purse after our ten days at Honolulu. The efforts of the small boys were apparently fruitless, so she resorted to the expedient of trying to gather up a carromato from some one leaving his at the Exposition Building. Every time a carromato drove up, she thrust her cherubic countenance out of the window and inquired of its occupant whether he was going to retain his conveyance or to dismiss it. Most of the visitors signified their intentions of never letting go a carromato when once they had it; and failure had rather dimmed the bravery of her inquiry, when one young man replied that he wished to retain his carromato, but that he was returning immediately to the city and would be happy to assist her and to take her wherever she wanted to go.

The Radcliffe girl closed with this handsome offer at once, accepting it in the chummy spirit which is supposed to be generated in the atmosphere of higher culture. A more worldly-wise woman might have suspected him, not only on grounds of general masculine selfishness, but on the fact that he had no business to transact at our hostelry. He did not enter its doors, but remained sitting in the carromato till she joined him. The girl had her mind on salary, however, and had no time to question motives. The banks had closed, but her guardian angel drove her to a newspaper office, where he introduced her, vouched for her, and induced the bookkeeper to cash her check. He then expressed a desire for a recognition of his services in the form of introductions to some of the teachers 
at the Exposition Building. The young woman was rather taken aback, for she had put all his civility down to disinterested masculine chivalry; but she reflected that she ought to pay the price of her own rashness. She was, however, a girl of resources. She agreed to let him call that afternoon and to introduce him to some of her new friends.

Then she came home and outlined the situation to an aged woman who was chaperoning her daughter, to a widow with two children, and to an old maid in whom the desire for masculine conquest had died for want of fuel to keep the flame alive. When the young man appeared, he found this austere and unbeautiful phalanx awaiting him. When the introductions were over and conversation was proceeding as smoothly as the caller's discomfiture would permit it to do, the artful collegian excused herself on the ground of a previous engagement. She went away blithely, leaving him in the hands of the three. Nor was he seen or heard of on those premises again. Doubtless he still thinks bitterly of the effects of higher education on the feminine temperament. It was duplicity duplicity not to be expected of a girl who could stick her head out of a window and hail the chance passerby as innocently as she did. 


\section{CHAPTER SIX}

\section{FROM MANILA TO CAPIZ}

I am appointed to a School at Capiz, on Panay Island - We anchor at the Lovely Harbor of Romblon - The Beaúty of the Night Trip to Iloilo - We halt there for a FeW Days - Examples showing that the Philippines are a "Mañana" Country - Kindness of some Nurses to the Teachers - An Uncomfortable Journey from Iloilo to Charming Capiz.

T $\mathrm{N}$ due time our appointments were made, and great was the wrath that swelled about the Expo1 sition Building! The curly-haired maiden who had fallen in loye with a waiter on the Thomas wept openly on his shoulder, to the envy of staring males. A very tall young woman who was the possessor of an M.A. degree in mathematics from the University of California, and who was supposed to know more about conic sections than any woman ought to know, was sent up among the Macabebes, who may in ten generations arrive at an elementary idea of what is meant by conic sections. Whether she was embittered by the thought of her scintillations growing dull from disuse or of scintillating head axes, I know not, but she made little less than a tragedy of the matter. The amount of wire-pulling that had been going on for stations in Manila was something enormous, and the disappointment was proportionate. 
I had stated that I had no choice of stations, was willing to go anywhere, and did not particularly desire to have another woman assigned with me. I had my doubts about the advisability of binding myself to live with some one whom I had known so short a time, and subsequent experience and the observation of many a quarrel grown out of the enforced companionship of two women who never had any tastes in common have convinced me that my judgment was sound. I was informed that my station would be Capiz, a town on the northern shore of Panay, once a rich and aristocratic pueblo, but now a town existing in the flavor of decayed gentility. I was eager to go, and time seemed fairly to drag until the seventh day of September, on which date the boat of the Compañia Maritima would depart for Iloilo, the first stage of our journey.

September the seventh was hot and steamy. We had endless trouble getting ourselves and our baggage to the Bridge of Spain, where the Francisco Reyes was lying. Great familiarity has since quite worn away the nervousness which we then felt on perceiving that our watches pointed to half an hour after starting time while we were yet adorning the front steps of the Exposition Building. Local boats never leave on time. From six hours to three days is a fair overtime allowance for them.

We finally arrived at the steamer in much agony and perspiration. The old saying about bustle and confusion was applicable to the Francisco Reyes if one leaves out "bustle." There were no immediate signs 
of departure, but there were evidences of the eleven o'clock meal. The muchachos were setting the table under an awning on the after-deck. A hard-shell roll with a pallid centre, which tastes like "salt-rising" bread and which is locally known as bescocho, was at each plate together with the German silver knives and spoons. The inevitable cheese was on hand, strongly barricaded in a crystal dish; and when I saw the tins of guava jelly and the bunch of bananas hanging from a stanchion, I had that dinner all mapped out. I had no time, however, to speculate on its constituent elements, because my attention was attracted by the cloth with which the boy was polishing off dishes before he set them down. This rag was of a fine, sootyblack color, and had a suggestion of oil about it as if it had been on duty in the engine-room: The youth grew warm, and used it also to mop his perspiring countenance. I ceased to inspect at that point, and went forward.

Several black and white kids of an inquisitive turn of mind were resting under my steamer chair, which had been sent on board the day before. They seemed to feel some injury at being dispossessed. I guessed at once that we carried no ice, and that the goats were a sea-faring conception of fresh meat. As their numbers diminished daily, and as we enjoyed at least twice a day a steaming platter of meat, garbanzos, peppers, onions, and tomato sauce, I have seen no reason to change my opinion.

Passengers continued to arrive until nearly two o'clock. There were one or two officers with their mu- 


$$
\text { • }
$$

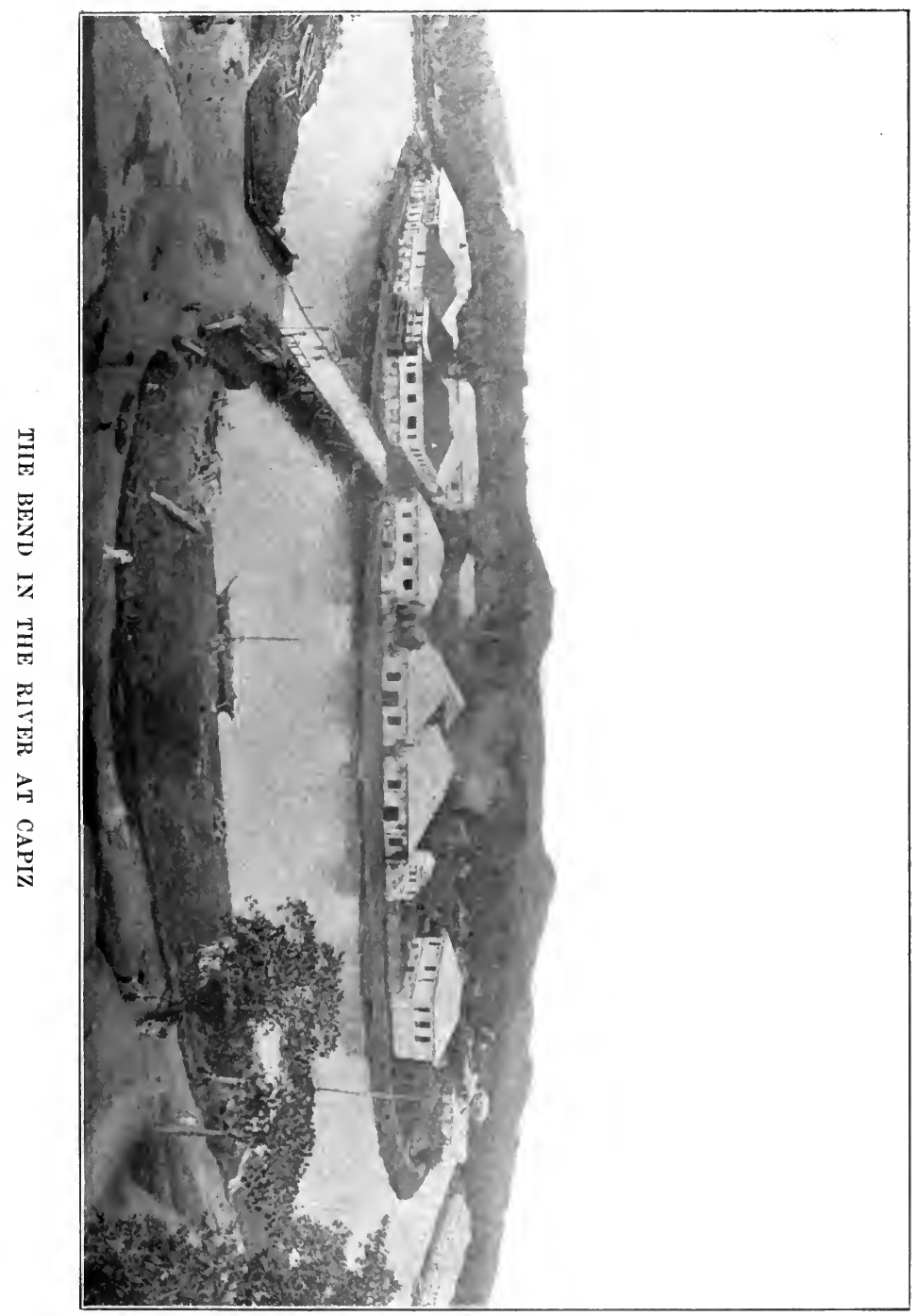



chachos, and some twenty or more schoolteachers. Six were women, and we found ourselves allotted the best there was.

We got away about three o'clock, and, after fouling a line over a row of cascos and threatening their destruction, sailed down the Pasig and out into the Bay. We passed Corregidor about sunset, met a heavy sea and stiff wind outside, and I retired from society. This was Saturday night. On Sunday noon we cast anchor in the lovely harbor of Romblon, and, defying sickness, I came on deck to admire.

The harbor at Romblon resembles a lake guarded by mountains which are covered with cocoanut trees clear to their summits. At one end - the end toward the entrance, which no unfamiliar eye can detect - a great plateau mountain called Tablas stretches across the view in lengthened bulk like the sky-line of some submarine upheaval. The waters are gayly colored, shadowed into exquisite greens by the plumy mountains above; and in a little valley lies the white town of Romblon with its squat municipal buildings, its gray old church, and a graceful campanile rising from a grassy plaza. They have dammed a mountain stream, so that the town is bountifully supplied with pure cold water, and with its clean streets and whitewashed buildings, it is a most attractive place.

The inhabitants of Romblon were eager to sell us mats, or petates, the making of which is a special industry there. Their prices had suffered the rise which is an inevitable result of American occupation, and were quite beyond our means. I succeeded afterwards 
in getting some Romblon mats through a Filipino friend for about one-fifth the price asked that day.

Our stay at Romblon was not lengthy. We got out some time in the late afternoon, and proceeded on our way. I cannot remember whether we occupied all that night and the next day in getting down to Iloilo or whether we made Iloilo in twelve hours. I do remember the night trip down the east coast of Panay, with Negros on the invisible left, and all about us a chain of little islands where the fisher folk were engaged in their night work of spearing fish by torchlight. Dim mountainous shapes would rise out of the sea and loom vaguely in the starlit distance, the curving beaches at their bases outlined by the torches in the bancas till they looked like boulevards with their lines of flickering lamps. I remember that we fell to singing, and that after we had sung everything we knew, an officer of the First Infantry who was going back to his regiment after a wound and a siege in hospital said enthusiastically: "Oh, don't stop. You don't know how it sounds to hear a whole lot of American men and women singing together."

It was somewhere between ten and midnight when a light flashed ahead, and beyond it lay a little maze of twinkles that they said was Iloilo. The anchor chains ran out with a clang and rattle, for our Spanish captain took no chances, and would not pick his way through the Siete Pecadores at night.

The Siete Pecadores, or Seven Sinners, are a group of islands, or rocks - for they amount to little more than that - some six miles north of Iloilo, just at the 


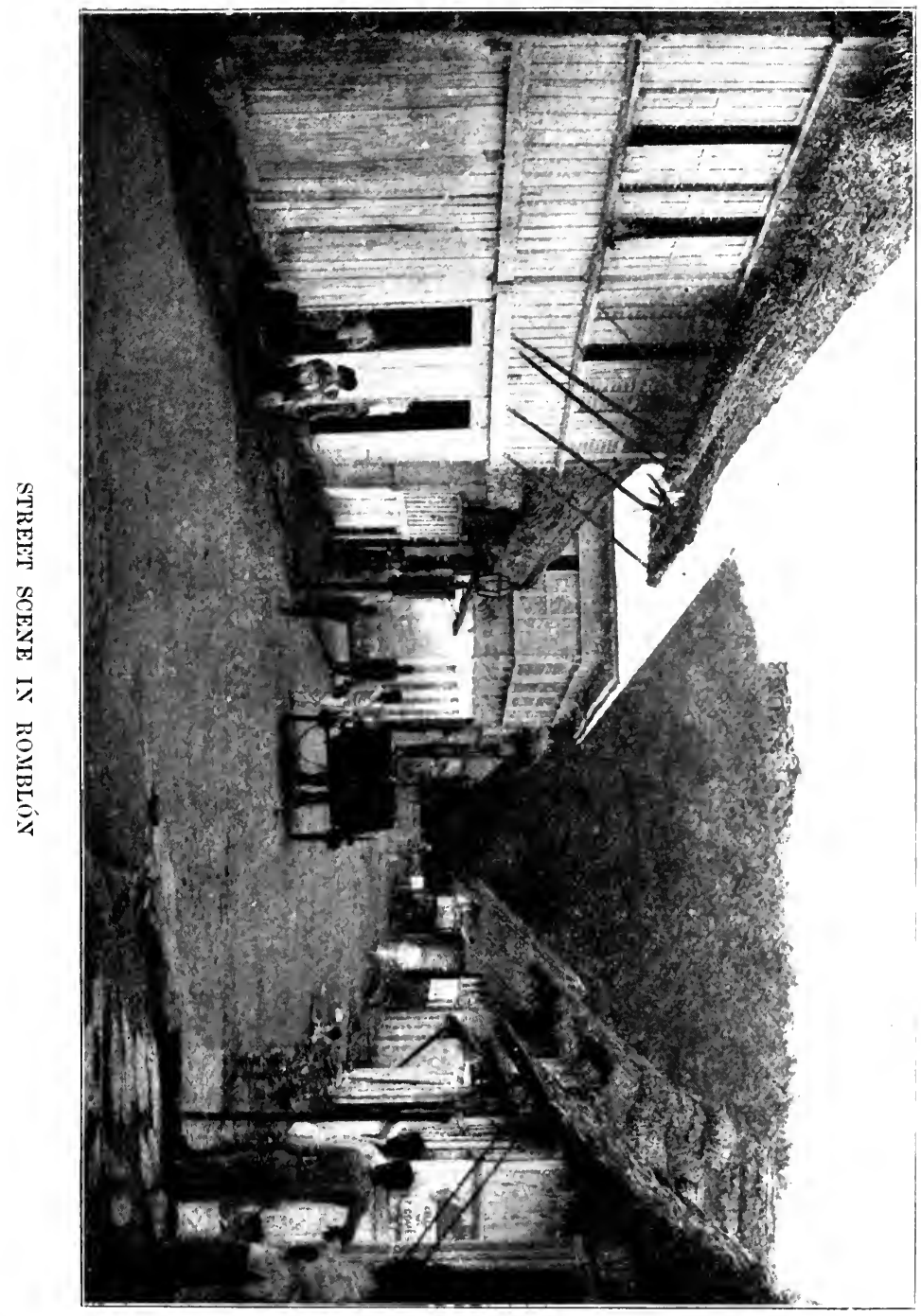



head of Guimaras Strait. On the east the long, narrow island of Guimaras, hilly and beautifully wooded, lies like a wedge between Panay and Negros. Beyond it the seven-thousand-foot volcano, Canlaon, on Negros, lifts a purple head. On the west lies the swampy foreshore of Panay with a mountain range inland, daring the sunlight with scarpy flanks, on which every ravine and every cleft are sunk in shadows of violet and pink. The water of the straits is glassy and full of jelly-fish, some of the white dome-like kind, but more of the purple ones that float on the water like a petalled flower.

Iloilo was a miniature edition of Manila, save that there were more gardens and that there was a rural atmosphere such as is characteristic of small towns in the States. The toy horses and the toy carromatos and quilices were there, and the four-horse wagons with a staring "U. S." on their blue sides. There were the same dusky crowds in transparent garments, the soldiers in khaki, the bugle calls, and the Stars and Stripes fluttering from all the public buildings.

As Iloilo was not well supplied with hotels, we women were barracked in a new house belonging to the American Treasurer, whose family had not yet arrived from the States. We found our old friend, the army cot, borrowed from the military quartermaster. There was a sitting-room well equipped with chairs and tables. Our meals were obtained from a neighboring boarding-house which rejoiced in the name "American Restaurant," and was kept by a Filipina. She was a good soul, and had learned how to make 
cocoanut balls, so that we bade a glad adieu to the bananas and guava jelly.

Our own particular waitress was a ten-year-old child, who said "hello" and smoked a cigar as long as herself. In a moment of enthusiasm one of our number who was interested in temperance and its allied reforms tipped Basilia a whole Mexican media-peseta. When the reformer became aware of Basilia's predilection for the weed, she wanted her media-peseta back, but Basilia was too keen a financier for that. The mediapeseta was hers - given in the presence of witnesses - and she somewhat ostentatiously blew smoke rings when she found the reformer's eye fixed upon her.

At Iloilo we picked up the word tao, which means "man," especially "laboring man," for the Filipinos usually fall back upon the Spanish words caballero and señor to designate the fortunate individuals whose hands are unstained with toil. We had picked up the vernacular of the street carromato in Manila. This is very simple. It consists of sigue, para, derecho, mano, and silla. For the benefit of such readers as do not understand pidgin Spanish, it may be explained that these words signify, respectively, "go on," "stop," "straight ahead," "to the right," and "to the left." The words mano and silla mean really "hand" and "saddle"; I have been told that they are linguistic survivals of the days when women rode on pillions and the fair incubus indicated that she wished to turn either to the side of her right hand or to the skirt side.

By this time we had begun to understand - just 
to understand in infinitely small proportion - what the old resident Americans meant when they joked about the Philippines as a mañana country. When we inquired when a boat would be in, the reply was "Seguro mañana" - "To-morrow for sure." When would it leave? "Seguro mañana." Nothing annoys or embarrasses a Filipino more than the American habit of railing at luck or of berating the unfortunate purveyor of disappointing news, or, in fact, of insisting on accurate information if it can be obtained. They are ready to say anything at a minute's notice. A friend of mine in Ilocos Norte once lost a ring, and asked her servant if he knew anything about it. The boy replied instantly, "Seguro raton," which is an elliptical form of "Surely a rat ate it." The boy had not stolen the ring, but he jumped at anything to head off complaint or investigation.

Time is apparently of no value in the Philippines. On the second day of our stay in Iloilo the Treasurer sent up two pieces of furniture for our use, a wardrobe and a table. They were delivered just before lunch, about ten o'clock, and the Treasurer would not be at home to sign for them till nearly one. When I came in from a shopping expedition, I found eight or ten taos sitting placidly on their heels in the front yard, while the two pieces of new furniture were lying in the mud just as they had been dumped when the bearers eased their shoulders from the poles. The noonday heat waxed fiercer, and the Treasurer was delayed, but nobody displayed any impatience. The men continued to sit on their heels, to chew their betel nut, and 
to smoke their cigars, and, I verily believe, would have watched the sun set before they would have left. In an hour or so the Treasurer appeared, and settled the account, the taos picked up the furniture and deposited it in the house, and the object lesson was over.

In spite of shopping, time hung somewhat heavy on - our hands at Iloilo. We made few acquaintances, for there were few civilian women, and the army ladies, so we were informed, looked askance at schoolteachers, and had determined that we were not to be admitted into "society." The army nurses asked us to five o'clock tea, and we went and enjoyed it. They were, for the most part, gentlewomen born, and the selfsacrifice of their daily lives had accentuated their native refinement. I have few remembrances more pleasant than those of the half-hour we spent in their cool sala. As for the tea they gave us and the delicious toast, mere words are inadequate to describe them. We became sensible that the art of cooking had not vanished from the earth. After the garbanzos and the bescochos and the guava jelly, how good they tasted!

In the course of two or three days we were notified that the vapor General Blanco would leave for Capiz on Saturday at five P. M., and some ten or twelve of us, destined for the province of that name, made ready to depart. I was the only woman in the party, but our Division Superintendent, who was personally conducting us and who was having some little difficulty with his charges, assured me that I was a deal less worry to him than some of the men were. I told him that I was quite equal to getting myself and my lug- 
gage aboard the Blanco. I had employed a native servant who said he knew how to cook, and I was taking him up to Capiz with an eye to future comfort. Romoldo went out and got a carabao cart, heaping it with my trunks, deck chair, and boxes. I followed in a quilez, and we rattled down to the wharf in good time.

The General Blanco was not of a size to make her conspicuous, and I reflected that, if there had been another stage to the journey and a proportional shrinkage in the vessel, it surely would have had to be accomplished in a scow. Although by no means palatial, the Buford was a fair-sized, ocean-going steamer. The Francisco Reyes was a dirty old tub with pretensions to the contrary; and the General Blanco - well, metaphorically speaking, the General Blanco was a coal scuttle. She was a supercilious-looking craft, sitting at a rakish angle, her engines being aft. She had a freeboard of six or seven feet, and possessed neither cabin nor staterooms, the space between the superstructure and the rail being about three feet wide. You could stay there, or, if you did not incommode the engineer, you could go inside and sit on a coal pile. There was a bridge approached by a rickety stair, and I judged that my deck chair would fill it completely, leaving about six inches for the captain's promenade. Behind the superstructure there was a sort of after-deck, nearly four feet of it. When my trunks and boxes had been piled up there, with the deck chair balancing precariously atop, and with Romoldo reclining luxuriously in it, his distraught pompadour was about on a level with the top of the smokestack. 
I really did n't see any room aboard for me, and sat down on a hemp bale to consider. Shortly after, the Division Superintendent arrived, åccompanied by several young men. He looked blank, and they whistled. Then he went on board to talk with the captain, while his assembled charges continued to ornament the hemp bales. Filipinos of all ages and sizes gathered round to stare and to comment.

At last the Division Superintendent came back with the information that the Blanco would tow up a lorcha which was lying a little distance down the river, and that we should find her a roomier and cooler means of transportation than the steamer. "Lorcha" is the name given to the local sailing vessels. Our lorcha was about sixty feet long, and, according to one of the teachers who had once seen Lake Michigan, was "schooner rigged." There was a deck house aft, which was converted into a stateroom for me. There were two bunks in it, each of which I declined to patronize. Instead I had my steamer chair brought over, and found there was plenty of room for it. There were little sliding windows, which with the open door afforded fairly decent ventilation. But the helm was just behind the deck house, and the helmsman either sat or stood on the roof, so that all night his responses to the steersman on the Blanco interfered with my sleep. Then, too, they kept their spare lanterns and their cocoanut oil and some coils of rope in there. At intervals soft-footed natives came in, and I was never certain whether it was to slay me or to get some of their stores. Once a figure blocked out the starlight 
at one of the windows, and I heard a rustling and shuffling on the shelf where my food tins were piled. So I said, "Sigue! Vamos!" and the figure disappeared.

The men opened their army cots on the forward deck, where the big sail cut them off from the rest of the ship. The next morning they reported a fine night's rest. I could not make so felicitous a report, for my stateroom was considerably warmer than the open air, and a steamer chair, though comfortable by day, does not make an acceptable bed.

We breakfasted from our private stores, and I found myself longing for hot coffee, instead of which I had to drink evaporated milk diluted with mineral water. The day was sunny, the heat beat fiercely off the water, and I burned abominably. Near noon we sighted a town close to the coast, and knew that we were nearing our journey's end.

We skirted the horn of a crescent-shaped bay, found a river's mouth, and entered. Here at least was the tropical scene of my imagination - a tide-swollen current, its marshy banks covered with strange foliage, and innumerable water lanes leading out of it into palmy depths. Down these lanes came bancas, sometimes with a single occupant paddling at the stern, sometimes with a whole family sitting motionless on their heels. Once we passed the ruins of what had been a sugar mill or a bino factory - probably the latter. Then the Blanco, puffing ahead, whistled twice, we rounded a curve and came full upon the town.

Though subsequent familiarity has brought to my 
notice many details that I then overlooked, that first impression was the one of greatest charm, and the one I love best to remember. There were the great, square, white-painted, red-tiled houses lining both banks of the river; the picturesque groups beating their clothes on the flat steps which led down to the water; and the sprawling wooden bridge in the distance where the stream made an abrupt sweep to the right.

On the left of the bridge was a grassy plaza shaded with almond trees, a stately church, several squat stone buildings which I knew for jail and municipal quarters, and a flag staff with the Stars and Stripes whipping the breeze from its top. Over all hung a sky dazzlingly blue and an atmosphere crystal clear. Back of the town a low unforested mountain heaved a grassy shoulder above the palms, and far off there was a violet tracery of more mountains.

I knew that I should like Capiz. 


\section{CHAPTER SEVEN}

MY FIRST EXPERIENCES AS A TEACHER OF FILIPINOS

After resting in a Saloon I arrive at my Lodging - I attend an Evening Party - Filipino Babies - I take Temporary Charge of the Boys' School - How the Opening of the Girls' School was anNounced - Curiosity of the Natives Regarding the New School-Difficulty of SECURING ORDER AT FIRST.

7 HE municipality of Capiz was expecting a woman teacher, for cries of "La maestra!"

1 began to resound before the boat was properly snubbed up to the bank; and when I walked ashore on a plank ten inches wide, there had already assembled a considerable crowd to witness that feat. They gathered round and continued to stare when I was seated in the principal saloon. Meanwhile a messenger was sent to find the American man teacher, who had been notified by telegram to arrange for my accommodation. The saloon was a very innocent-looking one, so that I mistook it for a grocery storeroom. Such as it was, it represented the best the Filipinos could do in the saloon line. One sees, in Manila and, for that matter, all up and down the Chinese and Japanese coasts, the typical groggery of America with somebody's "Place" printed large over the entrance, and a painted screen blocking the doorway with its suggestions of unseemliness. But the provincial saloon is still essentially 
Spanish - a clean, light room with no reservations, the array of bottles on the shelves smiling down on the little green cloth-covered tables where the domino and card games go on. There may be an ancient billiard table in one corner with its accompanying cue rack, and there is almost sure to be a little hole in the ceiling through which the proprietor's wife, who resides above, can peep down and watch the card games. It is a genuine family resort, too, for between four and seven all the town is likely to drop in, the women chaffering or gossiping while their lords enjoy a glass of beer and a game of dominoes.

The proprietor's wife must have had a fine look at me as I sat mopping my sunburned face. At last the American teacher came, a pleasant-faced young man who spoke Spanish excellently and was quite an adept at the vernacular. In due time I was ushered into a room in a house on the far side of the river, the window of which commanded a fine view of the bridge, the plaza, the gray old church, and the jail, with the excitements of guard mount and retreat thrown in.

The room had a floor of boards, each one of which was at least two feet wide. They were rudely nailed and were separated by dirt-filled cracks, but were polished into a dark richness by long rubbing with petroleum and banana leaves. The furnishings consisted of a wardrobe, a table, a washstand, several chairs, and a Filipino four-poster bed with a mattress of plaited rattan such as we find in cane-seated chairs. A snowwhite valence draped the bed. The mattress was covered with a petate, or native mat, and there were two 
pillows - a big, fat, bolstery one, and another, called abrazador, which is used for a leg-rest.

I bathed in the provincial bathroom. Manila, being the metropolis of the Philippines, has running water and the regular tub and shower baths in tiled rooms. The Capiz bathroom had a floor of bamboo strips which kept me constantly in agony lest somebody should stray beneath, and which even made me feel apologetic toward the pigs rooting below. There was a tinaja, or earthenware jar, holding about twenty gallons of water, and a dipper made of a polished cocoanut shell. I poured water over my body till the contents of the tinaja were exhausted and I was cool. Already I was beginning to look upon a bath from the native standpoint as a means of coolness, and incidentally of cleanliness.

When I got back to my room, my hostess and her sister came and sat with me while I unpacked my trunk and applied cold cream to my sunburnt skin. They were afraid that I should be triste because I was so far from home and alone, and they inquired if I wanted a woman servant to sleep in my room at night. I was quite unconscious that this was an effort to rehabilitate their conception of the creature feminine and the violated proprieties; and my indignant disclaimer of anything bordering on nervousness did not raise me in their estimation.

They left me finally in time to permit me to dress and gain the sala when the bugles sounded retreat. The atmosphere was golden-moted - swimming in the incomparable amber of a tropical evening. The river slipped along, giving the sense of rest and peace which 
water in shadow always imparts, and as the long-drawnout notes were caught and flung back by the echo from the mountains, the flag fluttered down as if reluctant to leave so gentle a scene. When the "Angelus" rang just afterwards, it was as if some benignant fairy had waved her wand over the land to hold it at its sweetest moment. The criss-crossing crowds on the plaza paused for a reverent moment; the people in the room stood up, and when the bell stopped ringing, said briskly to me and to one another, "Good evening." Then the members of the family approached its oldest representative and kissed his hand. It was all very pretty and very effective.

Afterwards we went out for a walk - at least they invited me to go for a walk, though it was a party to which we were bound. Filipinos, being devout Catholics, have a fashion of naming their children after the saints, and, instead of celebrating the children's birthdays, celebrate the saints' days. As there is a saint for every day in the year, and some to spare, and it is a point of pride with every one of any social pretension whatever to be at home to his friends on his patron saint's day, and to do that which we vulgarly term "set 'em up" most liberally, there is more social diversion going on in a small Filipino town than would be found in one of corresponding size in America. At these functions the crowd is apt to be thickest from four till eight, the official calling hours in the Philippines.

Starting out, therefore, at half-past six, we found the parlors of the house well thronged. At the head of the stairs was a sort of anteroom filled with men smok- 
ing. This antesala, as they call it, gave on the sala, or drawing-room proper, which was a large apartment lighted by a hanging chandelier of cut glass, holding about a dozen petroleum lamps. Two rows of chairs, facing each other, were occupied by ladies in silken skirts of brilliant hues, and in camisas and panuelos of delicate embroidered or hand-painted piña. We made a solemn entry, and passed up the aisle doing a sort of Roger de Coverley figure in turning first to one side and then to the other to shake hands. No names were mentioned. Our hostess said, by way of general announcement, "La maestra," and having started me up the maze left me to unwind myself. So I zigzagged along with a hand-shake and a decorous "Buenos noches" to everybody till I found myself at the end of the line at an open window. Here one of those little oblong tables, across which the Filipinos are fond of talking, separated me from a lady, unquestionably of the white races, who received the distinction of personal mention. She was "la Gobernadora," and her husband, a fat Chino mestizo, was immediately brought forward and introduced as "el Gobernador." He was a man of education and polish, having spent fourteen years in school in Spain, where he married his wife. After having welcomed me properly, he betook himself to the room at the head of the stairs where the men were congregated. A fat native priest in a greasy old cassock seemed the centre of jollity there, and he alternately joked with the men and stopped to extend his hand to the children who went up and kissed it.

I did my best to converse intelligently with the 
Gobernadora and the other ladies who were within conversational distance. A band came up outside and played "Just One Girl," and presently one of the ladies of the house invited the Governor's wife and me to partake of sweets. We went out to the dining-room, where a table was laid with snow-white cloth, and prettily decorated with flowers and with crystal dishes containing goodies.

There were, first of all, meringues, which we call French kisses, the favorite sweet here. There was also flaon, which we would call baked custard. In the absence of ovens they do not bake it, but they boil it in a mould like an ice-cream brick. They line the mould with caramel, and the custard comes out golden brown, smooth as satin, and delicately flavored with the caramel. Then there was nata, which is like boiled custard unboiled, and there were all sorts of crystallized fruits - pineapple, lemon, orange, and citron, together with that peculiar one they call santol. There were also the transparent, jelly-like seeds of the nipa palm, boiled in syrup till they looked like magnified balls of sago or tapioca.

I partook of these rich delicacies, though my soul was hungering for a piece of broiled steak, and I accepted a glass of muscatel, which is the accepted ladies' wine here. My hostesses were eager that I should try all kinds of foods, and a refusal to accept met with a protest, "Otra clase, otra clase." Then the Gobernadora and I went back to the sala, and another group took our places at the refreshment table.

I was much interested in the babies, who were strut- 
ting about in their finest raiment and were unquestionably annoyed at its restrictions. Filipino babies . are sharp-eyed, black-polled, attractive little creatures. Whether of high or low degree, their ordinary dress is adapted to the climate, and consists usually of a single low-necked garment, which drapes itself picturesquely across the shoulders like the cloaks of Louis the Fourteenth's time seen on the stage.

On state occasions, however, they are inducted into raiment which their deluded mothers fancy is European and stylish; but there is always something wrong. Either one little ruffled drawers leg sags down, or the petticoat is longer than the dress skirt, or the waistband is too tight, or mamma has failed to make allowance in the underclothing for the gauziness of the outer sheathing. As for the sashes with which the victims are finally bound, they fret the little swelled stomachs, and the baby goes about tugging at his undesirable adornment, and wearing the frown of one harassed past endurance. Sometimes it ends in flat mutiny, and baby is shorn of his grandeur, and prances innocently back into the heart of society, clad in a combination of waist and drawers which is associated in my memory with cotton flannel and winter nights. Nobody is at all embarrassed by the negligee; and as for the baby himself, he would appear in the garments of Eve before the Fall without a qualm.

After everybody had been served with sweets, a young Filipina was led to the piano. She played with remarkable technique and skill. Another young lady sang very badly. Filipinos have natural good taste in 
music, have quick musical ears, and a natural sense of time, but they have voices of small range and compass, and what voice they have they misuse shamefully. They also undertake to sing music altogether too difficult for any but professionals.

When the music was over, I was rather anxiously anticipating a "recitation," but was overjoyed to dis-" cover that that resource of rural entertainment has no foothold in the Philippines. Dancing was next in order. The first dance was the stately rigodon, which is almost the only square dance used here. When it was finished and a waltz had begun, I insisted on going home, for I was tired out. Somebody loaned us a victoria, and thus the trip was short. A deep-mouthed bell in the church tower rang out ten slow strokes as I threw back the shutters after putting out my light. The military bugles took up the sound with "taps," and the figure of the sentry on the bridge was a moving patch of black in the moonlight.

The Division Superintendent started inland the next morning to place the men teachers in their stations, and as he required the services of the American teacher in interpreting, I was told to go over and take charge of the boys' school, at that time the only one organized.

I went across the plaza and found two one-story buildings of stone with an American flag floating over one, and a noise which resembled the din of a boiler factory issuing from it. The noise was the vociferous outcry of one hundred and eighty-nine Filipino youths engaged in study or at least in a high, throaty clamor,.. over and over again, of their assigned lessons. When 


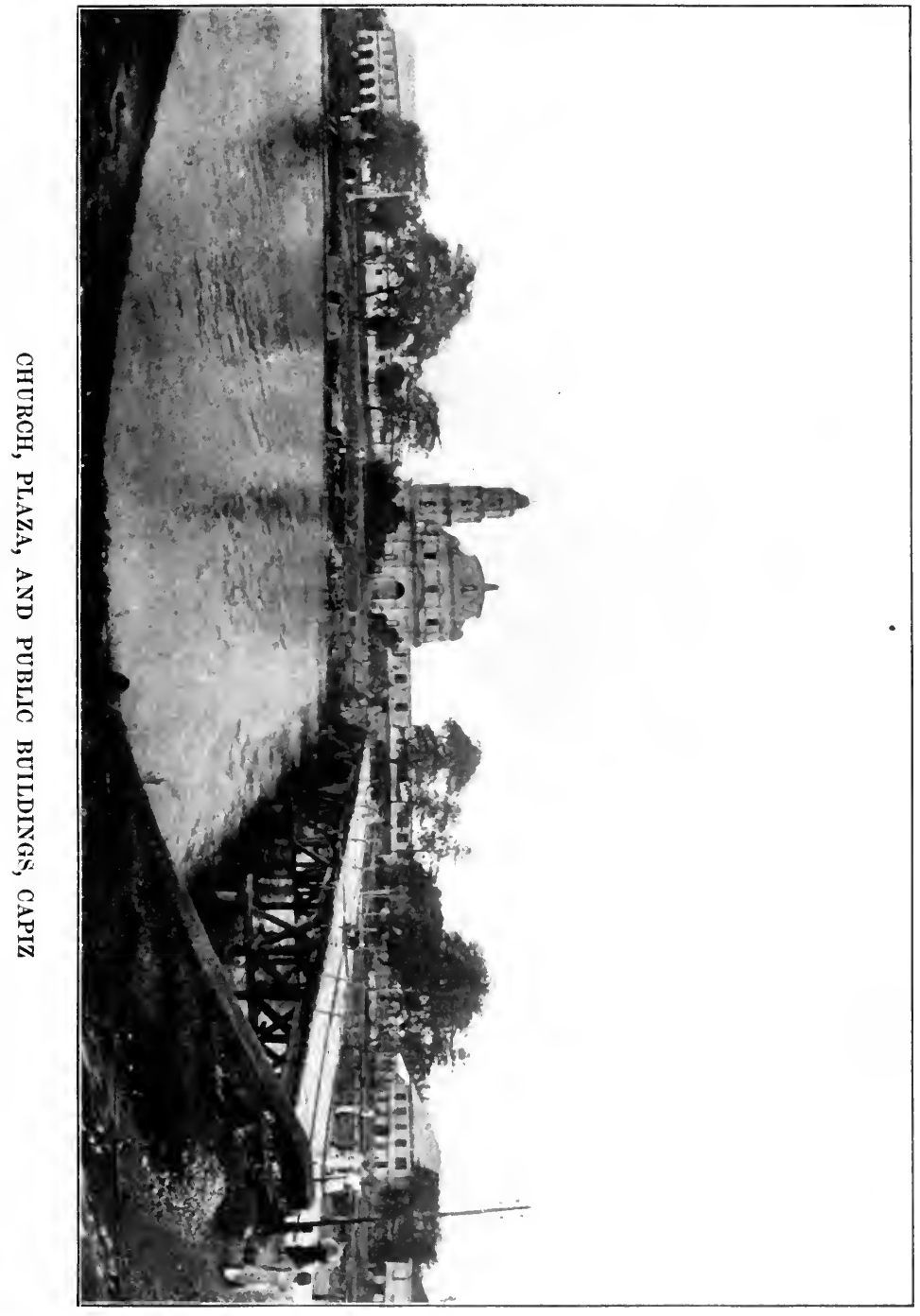



I went in, they rose electrically, and shrieked as by one impulse, "Good morning, modham." They were so delighted at my surprise at their facility with English that they gave it to me over and over again, and I saw that they had intuitions of three cheers and a tiger.

When I had explained to the teacher that I was there to relieve him, he explained it to the boys, and they replied with the same unanimity and the same robustness of voice, "Yis, all ri' !" So he went away, leaving me in charge of the boiler factory.

It stays in my recollection as the most strenuous five hours' labor I ever put in. Only two personalities were impressive, those of the pupil teacher who aided me, and who has since graduated from the University of Michigan (agricultural department), and of a very small boy who had possessed himself of a wooden box, once the receptacle of forty-eight tins of condensed milk, which he used for a seat. He carried the box with him when he went from one place to another, and more than one fight was generated by his plutocracy. He also sang "Suwanee River" in a clear but sweet nasal voice, and was evidently regarded as the show pupil of the school.

The school was popular not only with boys but with goats. Flocks of them wandered in, coming through the doors or jumping through the windows. I soon found that Filipino children are more matter-of-fact than American children. Nobody giggled when our four-footed friends came in, and until I gave an order to expel them their presence was accepted as a matter of course. When I suggested putting them out, I found 
the Filipino youth ready enough at rough play. The first charge nearly swept me off my feet, and turned the school into a pandemonium. After that the goats were allowed to assist in the classes at their pleasure.

During the next three days, what with the labor of school and the fatigue of entertaining most of the population of Capiz during calling hours, I was almost worn out. The Division Superintendent came" back the latter part of the week, and the Presidente, or mayor, sent out, at his request, a bandillo to announce the opening of a girls' school.

The bandillo corresponds to the colonial institution of the town crier. It consists usually of three native police, armed with most ferocious-looking revolvers, and preceded by a temporary guest of municipal hospitality from the local calabozo. This citizen, generally ragged and dirty and smoking a big cigar, is provided with a drum which he beats lustily. The people flock to doors and windows, and the curious and the little boys and girls who are carrying their baby relations cross saddle on their hips, fall in behind as for a circus procession. At every corner they stop, and the middle policeman reads the announcement aloud from a paper. Then the march is taken up again by those who desire to continue, and the rest race back to their doorways to wag their tongues over the news. The bandillo makes the rounds of the town and returns to the municipal hall whence it started. The prisoner goes back to jail, the police lay aside their bloodthirsty revolvers, and such is the rapidity with which news flies in the Philippines that, in a little more than twenty-four hours, 
the essentials of the bandillo may be known all over the province.

In spite of the bandillo I waited long for a pupil on the day of opening my school. My little friend of the milk box deserted his own classes and stationed himself at my door. After an interminable time he thrust his head inside the door and announced, "One pupil, letty."

It was a very small girl in a long skirt with a train a yard long and with a gauzy camisa and pañuelo - a most comical little caricature of womanhood. She was speechless with fright, but came on so recklessly that I began to suspect the cause of her determination. It was, in truth, behind her, as my groom of the front yard soon let me know. Again the elfin face and the wiry pompadour leaned round the door-jamb - "One more pupil, letty, - dthe girl's modther."

But she was not a pupil, of course, and she had only come in response to the heart promptings of motherhood, white, black, or brown, to talk about her offspring to the strange woman who was to usurp a mother's place with her so many hours of each day. She was quite as voluble as American mothers are, and her daughter was quite embarrassed by her volubility. The child sat stealing frightened glances at me and resentful ones at her mother.

Half an hour later, three more girls came in, and they continued to drop in during the rest of the morning till I had forty-five enrolled. Some of them were accompanied by their dogs, which curled up under the benches without disturbance. Several nursemaids also hap- 


\section{IMPRESSIONS OF THE PHILIPPINES}

pened along to give their charges a peep at the American school, and a crowd of citizens peered in at doors and windows and made audible remarks about the new institution.

Within a few days the enrolment ran up to one hundred and forty-nine. As this was too large a body to be handled by me alone, the teacher of Spanish days was brought back to the school, pending the arrival of more teachers from the States. She was a plump, middle-aged body who had a little - a very little English, but whose ideas of discipline, recitation, and study were too well fixed to permit of accommodation to our methods. She was unfailingly polite and kind, though I could see that she was often harassed by the innovations to which she could not accustom herself.

The school-house was one immense room, and one of the first acts of the Division Superintendent was to set in motion the forces which should separate it into three. This took time. First the Presidente had to approve, and the town council to act on his suggestion. The Municipal Treasurer, a native official, had to certify the cost to the Provincial Treasurer, an American civil appointee, and if the last-named official approved, the council could make the appropriation and order the work done.

Pending these changes, the Filipino teacher took one end of the room and I the other. We were sufficiently far apart not to interfere with each other's recitations. In order that all the pupils should have their reading and grammar recitations under my personal supervision, we changed classes at intervals. For the sake 
of the drill, I made the children move from one part of the room to the other, instead of changing with the other teacher myself. We made great efforts to accomplish this movement with order and decorum, but the result at first was a fizzle. The double column always began to move with dignity, but by the time it had advanced ten steps, excitement began to wax, the march became a hurry, the hurry grew to a rush, and the rush ended in a wild scramble for front seats. One little maid in particular was such an invariable holder of an advantageous position that my curiosity was aroused to see how she did it. I watched her, saw her glistening brown body - perfectly visible through the filmy material of her single garment - dive under the last row of seats and emerge triumphant at the front while the press was still blocking the aisles.

Disorder and excitement were, however, mere temporary conditions. Under repeated admonition and practice, the Filipino children moved about with more order and regularity, the habit of studying aloud was overcome, and the school began to show the organization and discipline to which Americans are accustomed.

The hardest thing to overcome was their desire to aid me in matters that I could manage better alone. If some one whispered and I tapped a pencil, instantly half the children in the room would turn around and utter the hiss with which they invoke silence, or else they would begin to scold the offender in the vernacular. Such acts led, of course, to unutterable confusion, and I had no little trouble in putting a stop to them. 


\section{CHAPTER EIGHT}

\section{AN ANALYSIS OF FILIPINO CHARACTER}

American Pupils and Filipino Pupils contrasted - The Filipinos' Belief that they are highly Developed Musicians - Their Morbid Sensitiveness to Criticism - Explanation of their Desire for Education - Their Belief that they codld achieve Great Success in ManUfaCtures, ARTs, aNd Literature if LEFT to gOVERN themselves - Their Lack of Creative Ability - Dilettanteism of Leading Filipinos - Manual Jealousies of the People - Lack of Real Democratic Spirit in America - The Pride of Filipino Men compared to that of American Women.

Yo long as they find firmness and justice in the $\infty$ teacher, Filipino children are far easier to discipline than are American children. At the first sign of weakness in the teacher or in the Government which is behind him, they are infinitely more unruly and arrogant than are the children of our own race. There is, in even the most truculent American child, a sense of the eternal fitness of things which the Filipino lacks. American children are restless and mischievous. They are on the alert for any sign of overstepping the limits of lawful authority on the part of the teacher, and they have no compunctions about forcing him to recognize that he rules by the consent of the governed, and that he must not mistake their complaisance for 
servility. On the other hand, they have, with rare exceptions, a respect for the value of a teacher's opinion in the subjects which he teaches, and will seldom contradict or oppose him in matters that pertain wholly to learning. A class of American children which would support in every possible way one of their number in defying authority would not hesitate to make that same companion's life a burden to him if he should set up his own opinion on abstract matters in contradiction to his teacher's. Except when a teacher signally proves his incapacity, American children are willing to grant the broad premise that he knows more than they do, and that, if he does not, he at least ought to know more. Filipino children reverse this attitude. They are quite docile, seldom think of disputing authority as applied to discipline, but they will naively cling to a position and dispute both fact and philosophy in the face of quoted authority, or explanation, or even of sarcasm. The following anecdote illustrates this peculiarity. It happened in my own school and is at first hand.

One of the American teachers was training a Filipino boy to make a recitation. The boy had adopted a plan of lifting one hand in an impassioned gesture, holding it a moment, and of letting it drop, only to repeat the movement with the other hand. After he had prolonged this action, in spite of fiequent criticism, till he looked like a fragment of the ballet of "La Poupée," the teacher lost patience.

"Domingo," she said, "I have told you again and again not to make those pointless, mechanical ges- 
tures. Why do you do it? They are inappropriate and artificial, and they make you look like a fool."

Domingo paused and contemplated her with the pity which Filipinos often display for our artistic inappreciativeness.

"Madame," he replied in a pained voice, "you surprise me. Those gestures are not foolishness. They are talent. I thought they would please you."

In my own early days I was once criticised by one of the young ladies of Capiz for my pronunciation of the letter $c$ in the Spanish word ciudad. I replied that my giving the sound of th to the letter was correct Spanish, whereupon she advised me to pay no attention to the Spanish pronunciation, as the Filipinos speak better Spanish than do the Spanish themselves. What she meant was that the avoidance of th sounds in $c$ and $z$, which the Filipinos invariably pronounce like $s$, is an improvement to the Spanish language. I imagined some of that young lady's kindred ten years later arguing to prove that the Filipino corruption of th in English words - pronouncing "thirty" as "sirty," and "thick" as "sick" — arguing that such English is superior to English as we speak it. Here are some typically mispronounced English sentences: "If Maria has seben fencils and see loses sree, see will hab four fencils left, and if her moser gibs her eight fencils, see will hab twel' fencils in all." Here is another: "Pedro has a new fair of voots." Another: "If one fint ob binegar costs fi' cents, sree fints will cost sree times fi' cents, or fikteen cents." It would, I think, be hard to convince us that the euphonic 
changes in these words are an improvement to our language.

Some four years ago, I was teaching a class in the Manila School of Arts and Trades, and was giving some directions about the word form of English sentences. I advised the class to stick to simple direct sentences, since they would never have any use for a literary style in English. Some six or eight young men instantly dissented from this proposition, and insisted that they were capable of acquiring the best literary style. Not one of them could have written a page of clear, grammatical, idiomatic English. I tried to make it clear to them that literary English and colloquial English are two different things, and that what they needed was plain, precise English as a medium of exchange in business, and I said, incidentally, that such was the English possessed by the major portion of the Englishspeaking race. I said that although the American nation numbered eighty millions, most of whom were educated and able to make an intelligent use of their language in conversation or in writing, the percentage of great writers and speakers always had been small and always would be so.

When I had finished, the son of a local editor, arose and replied as follows: "Yes, madame, what you say of Americans is true. But we are different. We are a literary people. We are only eight millions, but we have hundreds and thousands of orators. We have the literary sense for all languages."

Nearly thirty years ago, when I'was a pupil in the Kansas City, Missouri, High School, the stepson of a 
United States Circuit judge made a brutally rude and insubordinate reply to a woman teacher who said to him, in reference to an excuse which he had given for tardiness, "That is not a good excuse." The young man turned an insolent eye upon the teacher - a grayhaired woman - and replied, "It 's good enough for me. What are you going to do about it?"

I cannot conceive that a Filipino child would be guilty of such insolence, such defiance of decency and order. But never have I met an American child who would have the artless indiscretion to put himself in the position of Domingo. The American child does not mind violating a rule. He is chary of criticising its propriety or its value. In other words, the American child does not mind doing wrong, but he is wary of making a fool of himself; and I have yet to meet the Filipino child who entertained the faintest suspicion that it was possible for him to make a fool of himself. Nor is the attitude of dissent among Filipinos limited to those who express themselves. It is sometimes very trying to feel that after long-winded eloquence, after citation and demonstration, you have made no more real impression upon the silent than upon the talkative, and that, indeed, the gentle reserve of some of your auditors is based upon the conviction that your own position is the result of indomitable ignorance. One of my friends has met this spirit in a class in the Manila High School. A certain boy insists that he has seen the iron head of a thunderbolt, and although he makes "passing grades" in physics, he does not believe in physics. He regards our explanations of the phenomena of lightning as a 


$$
\text { 文 }
$$

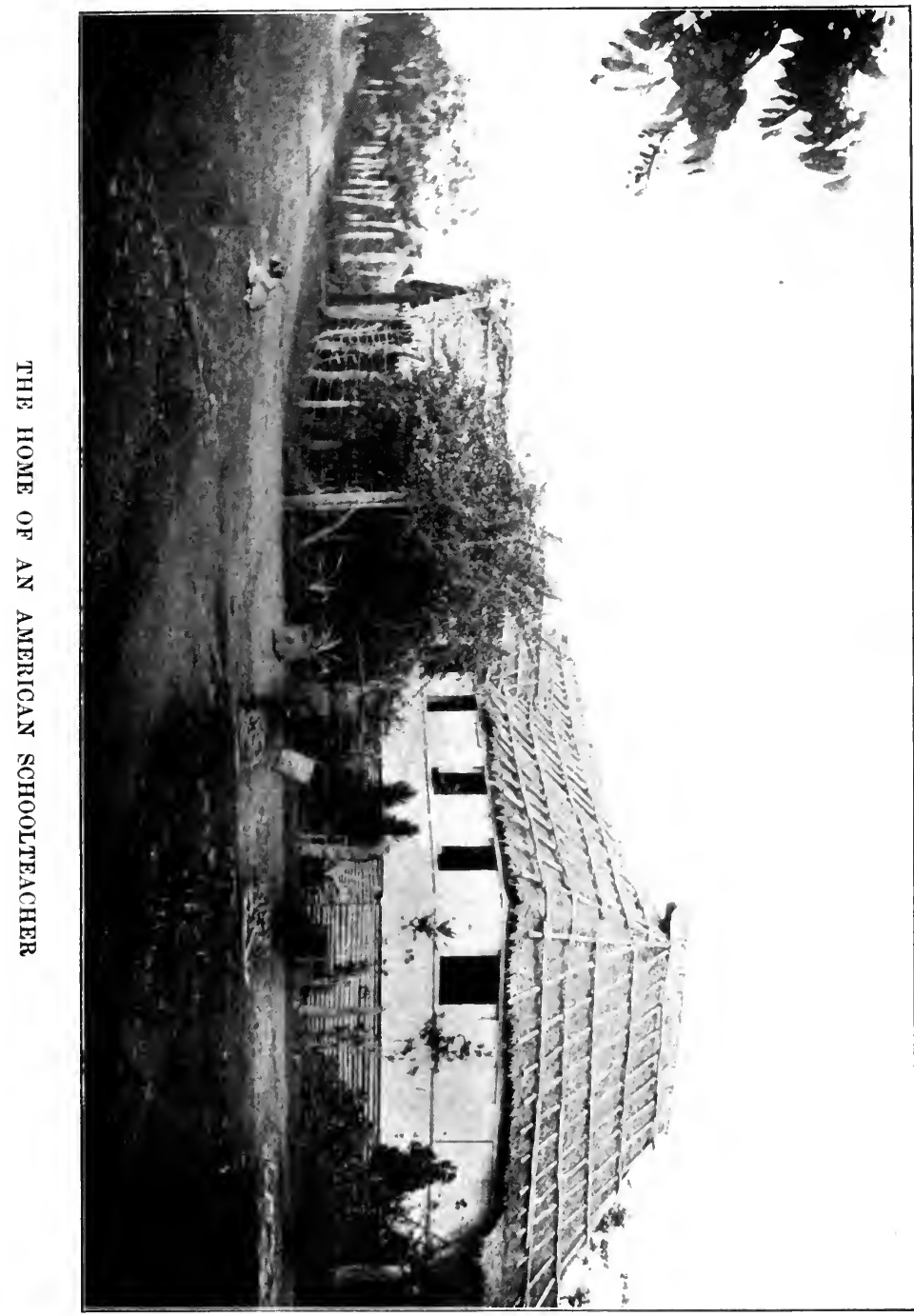



parcel of foolishness in no wise to stand the test of his own experience, and nothing can silence him. "But, ma'am," he says, when electricity is under discussion, "I can see the head of a thunder under our house." This young gentleman will graduate in a year or two, and the tourist from the States will look over the course of study of the Manila High School and go home telling his brethren that the Filipino children are able to compete successfully with American youth in the studies of a secondary education. I myself had a heart-breaking time with a sixth-grade class in one of the intermediate schools of Manila. The children had been studying animal life and plant life, and could talk most learnedly about anthropoid apes, and "habitats" and other things; but they undertook to convince me that Filipino divers can stay under water an hour without any diving apparatus, and that the reason for this power is that the diver is "brother to a snake" that is, that when the mother gave birth to the child, she gave birth to a snake also, and that some mysterious power remains in persons so born.

Filipino children are not restless and have no tradition of enmity between teacher and pupil to urge them into petty wrong-doing. Their attitude toward the teacher is a very kindly one, and they are almost uniformly courteous. Their powers of concentration are not equal to those of American children, and they cannot be forced into a temporarily heavy grind, but neither do they suffer from the extremes of indolence and application which are the penalty of the nervous energy of our own race. They are attentive (which the 
American child is not) but not retentive, and they can keep up a steady, even pull at regular tasks, especially in routine work, at which American children usually rebel. In fact, they prefer routine work to variety, and grow discouraged quickly when they have to puzzle out things for themselves. They will faithfully memorize pages and pages of matter which they do not understand, a task at which our nervous American children would completely fail. They are exceedingly sensitive to criticism, and respond quickly to praise. Unfortunately the narrow experience of the race, and the isolation and the general ignorance of the country, make praise a dangerous weapon in the hands of a teacher; for a child is apt to educe a positive and not a relative meaning from the compliment. Filipino children have not attained the mental state of being able to qualify in innumerable degrees. If a teacher hands back a composition to an American boy with the words "Well done," the child understands perfectly that his instructor means well as compared with the work of his classmates. The Filipino is inclined to think that she means positively well done-above the average for all the world. I once complimented a class in Capiz on the ease with which they sang fourpart music, and said, what I truly feel, that the Filipinos are a people of unusual musical ability. They managed to extract from the compliment the idea that the musical development of the Filipinos is far in advance of that of the Americans.

Middle-class Filipinos have a very inadequate conception of the tremendous wealth of artistic, literary, 
and musical talent interwoven with the world's development, and are especially inclined to pride themselves upon their racial excellence in these lines, where, in truth, they have achieved almost no development whatever in spite of the possession of undoubted talent. They do not understand the value of long training, and are inclined to assume that the mere possession of a creative instinct is final evidence of excellence in any art.

It will be some time before what real talent they have will make itself felt in any line, because it will take a great deal of tactful handling to make them reveal their natural artistic trend instead of falling into imitation of Europe and America. It is strange that a people so tenacious of its opinions with regard to matters of fact should be so willing to surrender its ideal with regard to the thing of which a nation has most reason to be tenacious, its natural expression. But the whole race is so morbidly sensitive to the sneer that everything Filipino is necessarily crude that the young art student or the young musical student feels that his only hope of winning commendation is in painting or playing or composing after European models; while as for the populace at large it has its own standards in which other motives than artistic excellence play the largest part.

I had a friend, a young Filipino girl, who has been one of the most diligent among the pupils of the American schools. She was staying with me two or three years ago when my publisher sent me a copy of a primer intended for use in the Philippines, and which had just 
been gotten out in the United States. The publisher had spared no expense in his illustrations, and we were tremendously proud of the artistic side of the book. This Filipino girl had heard me use the expression "poor white trash," and I had explained to her how the Southern negroes use the words as a term of derision of those who fail to live up to the traditions of race and family. When I took my book to her in the joy of an author in her first complete production, she looked at it a minute and burst into tears. "Poor Filipino trash!" was all she could say for a long time, and I finally pieced it out that she was enraged because the Filipino boys and girls in my book were sometimes barefooted, sometimes clad in chinelas, and wore native camisas instead of American suits and dresses. I pointed out to her that not one Filipino child in a hundred dresses otherwise, but my argument was of no avail. The children in the American readers wore natty jackets and hats and high-heeled shoes, and winter wraps, even at play, and she wanted the Filipino children to look the same.

A great deal has been said in the American press about the eagerness for education here. The desire for education, however, does not come from any real dissatisfaction which the Filipinos have with themselves, but from eagerness to confute the reproach which has been heaped upon them of being unprogressive and uneducated. It is an abnormal condition, the result of association of a people naturally proud and sensitive with a people proud and arrogant. At present the desire for progress in things educational and even in 
things material is more or less ineffective because it is fed from race sensitiveness rather than from genuine discontent with the existing order of things. The educated classes of Filipinos are not at all dissatisfied with the kind and quality of education which they possess; agriculturists are not dissatisfied with their agricultural implements; the artisans are not, as a class, dissatisfied with their tools or ashamed of their labor. If you talk to a Filipino carpenter about the carefully constructed houses of America, he does not sigh. He merely says, "That is very good for America, but here different custom." Filipino cooks are not dissatisfied with the terrible fugons which fill their eyes with smoke and blacken the cooking utensils, and have to be fanned and puffed at every few minutes and occasionally set the house on fire. The natural causes of growth are not widely existent, and it is still problematic if they will ever come into being. Meanwhile growth goes on stimulated by the eternal criticism, the sting of which the Filipinos would move heaven and earth to escape.

Our own national progress and that of the European nations from whom we are descended have been so differently conceived and developed that we can hardly realize the peculiar process through which the Filipinos are passing. We cannot conceive of Robert Fulton tearing his hair and undertaking a course in mechanics with the ulterior view of inventing something to prove that the American race is an inventive one. We cannot imagine Eli Whitney buried in thought, wondering how he could make a cotton gin to disprove 
the statement that the Americans are an unprogressive people. Cyrus Hall McCormick did not go out and manufacture a reaper because he was infuriated by a German newspaper taunt that the Americans were backward in agriculture. Nor can we fancy that John Hay while dealing with the Chinese erisis in 1900 was continually distracting his mind from the tremendously grave points at issue by wondering if he could not do something a little cleverer than the other diplomats would do.

All the natural laws of development are turned around in the Philippines, and motives which should belong to the crowning years of a nation's life seem to have become mixed in at the beginning - a condition, due, of course, to the fact that the Filipinos began the march of progress at a time when the telegraph and the cable and books and newspapers and globe-trotters submitted their early development to a harrowing comparison and observation. The Filipino is like an orphan baby, not allowed to have his cramps and colic and to cut his teeth in the decent retirement of the parental nursery, but dragged out instead into distressing publicity, told that his wails are louder, his digestive habits more uncertain, his milk teeth more unsatisfactory, than the wails or the digestive habits or the milk teeth of any other baby that ever went through the developing process. Naturally he is selfconscious, and - let us be truthful - not having been a very promising baby from the beginning, both he and his nurses have had a hard time.

However, turned around or not, we are not respon- 
sible for the condition. The Filipinos had arrived at the self-conscious stage before we came here, and we have had to accept the situation and make the best of it.

The American press of Manila, with the very best of intentions, has indulged itself in much editorial comment, and the more the condition of things is discussed, the more the native press strengthens in its quick sensitiveness. The present attitude of the upper, or governing, class of Filipinos is this: "We want the best of everything in the world - of education, of morals, of business methods, of social polish, of literature, art, and music, of roads and bridges, of agricultural machinery, and of local transportation, and we can attain these things." They have laid down in the beginning a premise for which no inductive process can be found as justification, - that the Filipino people is capable of doing anything which any other nation has done; and that, given time and opportunity - especially the opportunity of managing their own process of development - they will demonstrate their capacity. The flat contradiction of this position which is not infrequently taken by Americans in discussing Filipinos is, of course, as extreme as the Filipino position itself, and, as an observer, I have little to do with either. But at the present time I do feel warranted in stating that the mass of intelligent Filipinos fail to distinguish between critical or appreciative ability and real creative ability, and that what they are acquiring in huge doses just now is the critical and not the creative. Moreover, of the great body of persons who make the 
demand for the best, only a very few have any idea of what is the best except in book learning and social polish. The prominent men among the Filipinos today are those who were educated in Europe or in Filipino schools modelled on European patterns. Their idea of education is a social one - an education which fits a man to be considered a gentleman and to be an adornment to the society of his peers. They have no conception of the American specialization idea in education which grants a doctor's degree to a man who says "would have went" and "He come to my house yesterday." The Filipino leaders have a perfectly clear idea of what they want educationally, of what they consider the best, and they are jealously watching the educational department to see that they get it. The American press urges more and more manual training, and the Filipino press, because manual training is in the list of things marked "best," echoes the general call. But there is no small body of hobbyists in the Islands keeping a jealous eye on the manualtraining department of education. It could be dropped out of the curriculum by simply allowing it to become less and less effectual, and so long as no formal announcement was made the Filipinos would not find out what was being done. But in Manila and in most provincial towns there are enough Filipinos who know what musical instruction is to watch that the musical training be not too badly administered.

There is plenty of complaint about the Sanitary System of Manila, there are plenty of people to complain about what is being done, but there is no small 
organized body of Filipinos whose paramount interest in life is fixed upon sanitation and health, and who make it their thankless task to harry the department and to preach ceaselessly at the unthinking public till they get what they want. The legislators of the Philippines are gentlemen born, men educated in conformity to the ideals of education in aristocratic countries, but unfortunately they have not had, owing to the political conditions which have prevailed here, the practical experience of an aristocratic body in other lands. In Mrs. Ward's "William Ashe" there is an analysis of a gouty and rather stupid old statesman, who is so exactly a summary of what a Filipino statesman is not that I cannot forbear quoting it here:

"He possessed that narrow, but still most serviceable fund of human experience which the English land-owner, while our English tradition subsists, can hardly escape if he will. As guardsman, volunteer, magistrate, lord lieutenant, member (for the sake of his name and his cares) of various important commissions, as military attaché even for a short time to an important embassy, he had acquired, by mere living, that for which his intellectual betters had often envied him - a certain shrewdness, a certain instinct both for men and affairs which were often of more service to him than finer brains to other persons.".

The only large practical experience which Filipino leaders have enjoyed has come through their being land-owners and agriculturists. But agriculture has not been competitive; and when the land-owning class travelled, it was chiefly in Spain, which can hardly be 


\section{IMPRESSIONS OF THE PHILIPPINES}

called a progressive agricultural country. Of men of the artisan class who have worked their way up by their own efforts from ignorance to education, from poverty to riches; of men who have had any large available experience in manual labor or in specialized industries, the present Assembly feels the lack. The Filipino leaders are a body of polished gentlemen, more versed in law than in anything else, with varying side lines of dilettante tastes in numerous directions.

Such as they are, the schoolboy desires to be. One of the periodic frenzies of the local American press is an appeal to teachers - why are they not remodelling character, why do not the aims and ideals which it is their business to instil make a greater showing after ten years of American occupation? American teachers have talked themselves hoarse, and as far as talking can go, they have influenced ideals. The child's conscious ideal about which he talks in public, and to which he devotes about one one-thousandth of his thinking time, is some such person as George Washington, or Abraham Lincoln, or James A. Garfield, who drove the canal boat and rose to be President of the United States. But the subconscious ideal which is always in his mind, upon which he patterns unthinkingly his speech and his manners and his dreams of success, is - and it would be unnatural if it were otherwise some local potentate who will not carry home his own little bag of Conant currency when he receives his salary at the end of the month. What are a name and a few moral platitudes about a dead-and-gone hero? What can they mean to a shirtless urchin with a hungry 


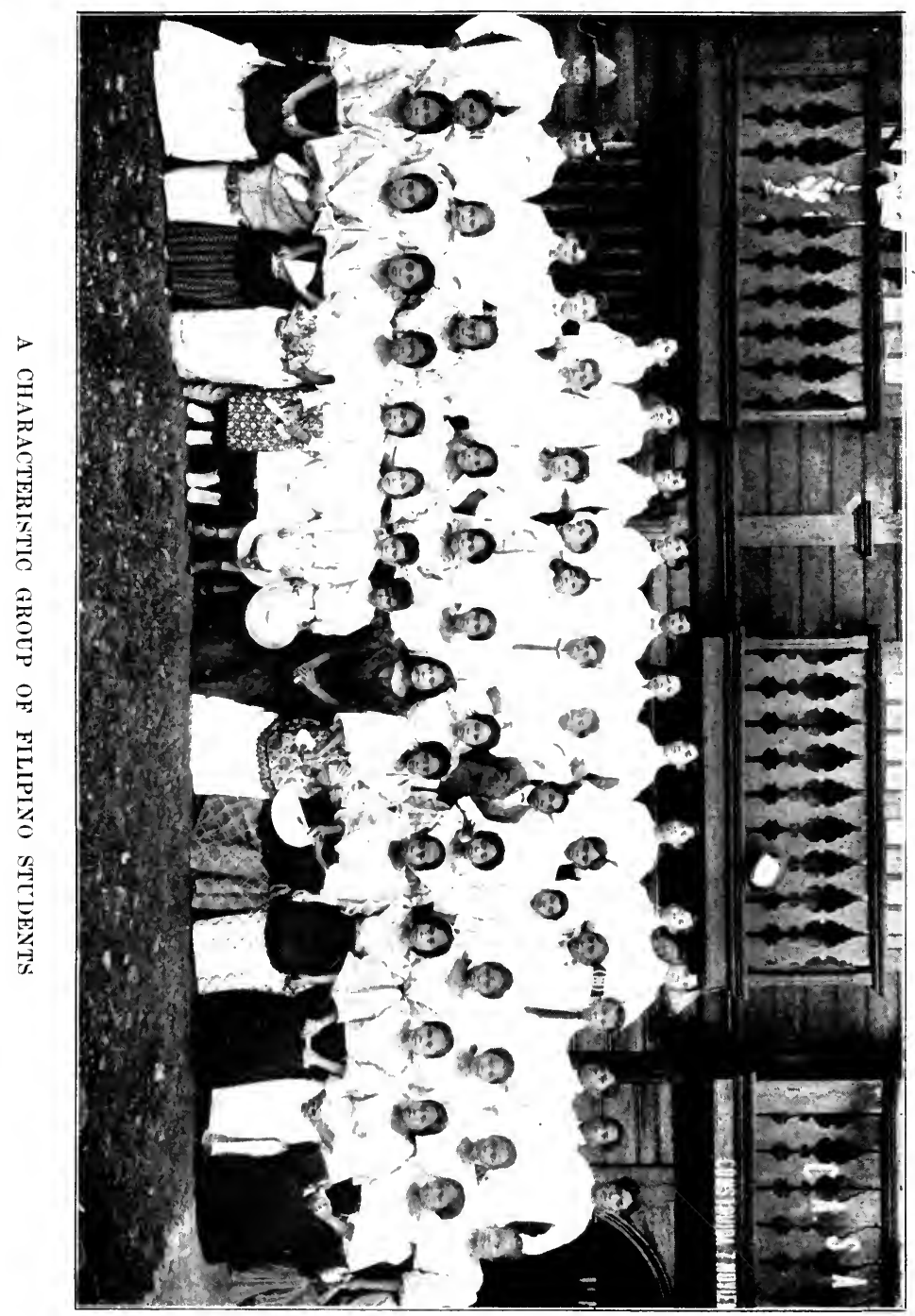



stomach, against the patent object-lesson of his own countryman whom not only his fellow citizens, but the invader, must treat with consideration? It would be far easier to distract the attention of the children of the State of Ohio from their distinguished fellow-citizens, William H. Taft and John D. Rockefeller, to fix it upon the late Lord Cromer or that Earl of Halifax known as the "Trimmer," than it is to tell a Filipino child that the way to distinction lies through toil and sweat. Children are very patient about listening to talk, but they are going to pattern themselves upon what is obvious. Twenty or thirty years from now, when the American school system will have aided certain sons of the people, men of elemental strength, to bully and fight their way to the front, and they will have become the evidence that we were telling the truth - then will the results be visible in more things than in annual school commencements and in an increase in the output of stenographers and bookkeepers.

The weakest point in a Filipino child's character is his quick jealousy and his pride. His jealousy is of the sort constitutionally inimical to solidarity. Paradoxical as the statement may seem, the Filipinos are more aristocratic in their theories of life than we are, and more democratic in their individual constitution. Our democracy has always been tempered by common sense and practicality. We like to say at church that all men are brothers, and on the Fourth of July to declare that they are born free and equal ; but we do not undertake to put these theories into practice. Every individual citizen of the United States is not walking 
about with a harrowing dread of doing something that admits a lesser self-esteem than his neighbor may possess. If a fire breaks out in his neighborhood, and a little action on his part can stop it before it gets a dangerous start, he does not hesitate to act for fear doing so will show him possessed of less personal pride than his neighbor up the street. If he is earning sixty dollars a month, and learns that some other employee in another house is getting more money for the same work, he does not take the chances of starvation because to submit to the condition is to admit that he is less important than another man. Yet the whole laboring element of the Filipino people is permeated by just such a spirit. It is practically impossible to fix a price for labor or for produce by any of the laws of supply and demand that regulate such things elsewhere. The personal jealousies, the personal assertions of individuals continually interfere with the normal conditions of trade. If in the market some American comes along in a hurry and pays a peso for a fish, the normal price of which is about thirty-five cents, the price of fish goes up all through the market - for Americans. You may offer eighty cents and be refused, and the owner will sell two minutes after to a Filipino for thirty-five. But in so doing he does not "lose his face." The other man got a peso from an American, and a man who takes less - from an American - is owning himself less able than his companions.

We talk of democracy, but we never know how little democratic we are till we come in contact with the real article. Can you conceive what would be the 
commercial chaos of America to-morrow if the humblest laborer had the quick personal pride of the millionaire? With all our alleged democracy, we realize the impossibility of ringing Mrs. Vanderbilt's door-bell and asking her to sell us a few flowers from her conservatory or to direct us to a good dressmaker, though we can take just such liberties with houses where the evidences that money would be welcome are patent.

The American laborer does not mind going to and from his work in laboring clothes, and he makes no attempt to seem anything but a laboring man. But you cannot tell in a Manila street car whether the whiteclad man at your side is a government clerk at sixty pesos a month or a day laborer at fifteen. I once lost a servant because I commanded him to carry some clothes to my laundress. "Go on the street with a bundle of clothes, and get into the street car with them! I would rather die!" he said; and he quitted rather than do it.

Compare that with the average common-sense attitude of the American laboring man or even the professional man. Until he becomes really a great man and lives in the white light of publicity, the American citizen does not concern himself with his conduct at all as it relates to his personal importance. He is likely to argue that he cannot do certain things which violate his ideal of manhood, or other things which are inconsistent in a member of the church, or other things which are unworthy of a democrat, or of a member of the school board, or even of an "all-round sport." Whatever the prohibitive walls which hedge the freedom of 


\section{IMPRESSIONS OF THE PHILIPPINES}

his conduct, each is a perfectly defined one, a standard of conduct definitely outlined in his mind, to which he has pledged his allegiance; but he has no large conception that most useful things are forbidden pleasures to him because of a sense of personal importance. He has no God of the "I," no feeling that makes him stay his hand at helping a cochero to free a fallen and injured horse, while he looks to see that some other man of his class is helping also.

There is a perfectly defined class system in the Philippines, and, between class and class, feeling is not bitter; but within each class jealousy is rampant. The Filipino, though greatly influenced by personality, does not yet conceive of a leadership based upon personality to which loyalty must be unswervingly paid. He feels the charm of personality, he yields to it just so long as it falls in with his own ideas, but the moment it crosses his own assertiveness he is ready to revolt. Many Americans speak of this characteristic as if it were a twist in character. My own opinion is that it is a passing phase, due to the Filipino's lack of the "narrow, but most serviceable fund of human experience." But no matter to what cause the condition is due, it makes a great difference in the life of the individual and of the social body as a whole that each unit has fixed his ideal of conduct upon an illimitable consciousness of personal importance, instead of upon perfectly defined ideals in particular matters. It makes for

(b) femininity in the race.

If the reader will meditate a little upon the difference between masculine pride and feminine pride in America, 
he will probably agree with me that masculine pride centres largely in loyalty to well-defined ideals of what is manly, or honorable, or bold, or just, or religious in short, it tries to live up to the requirements of a hundred separate standards. On the other hand, feminine pride, outside of its adherence to what is chaste and womanly, consists of pride in self, a kind of self-estimate, based frequently upon social position, sometimes on a consciousness of self-importance which comes through the admiration of men. In either case the pride is likely to show itself in a jealous exaction of consideration for the individual. Such is Filipino pride. It is almost wholly concerned in guarding its vested rights, in demanding and exacting the consideration due the importance of its possessor.

Filipinos are hard to enlist in any new undertaking until they are certain that success will bring "consideration." They love newspaper notices and publicity, they love the centre of the stage, and every new advance in intelligence is bulwarked by a disproportional demand for "consideration."

Filipino men are not lacking in manly qualities. They have the stronger courage, the relatively stronger will and passions which distinguish the men of our own race. But they are harder to get along with than are Filipino women, because their sense of sex importance is so much exaggerated, and because, as Mr. Kipling would put it, they "have too much ego in their cosmos." The secret consciousness of power is not enough for them. They must flash it every minute in your eyes, that you may not forget to yield the adulation due to 


\section{IMPRESSIONS OF THE PHILIPPINES}

power. Like women, they get heady on a small allowance of power; and indeed in both sexes there are emphasized certain characteristics which we are accustomed to look upon as feminine. Their pride is feminine as I have analyzed it. They rely upon intuition to guide them more than upon analysis. In enlisting coöperation, even in public matters, they are likely to appeal to a sentiment of friendship for themselves instead of demonstrating the abstract superiority of their cause. They will make a haughty public demand, but will not scruple to support it with secret petition and appeal. They are adepts at playing upon the weakness and petty vanity of others; and they deal gently with the strong, but boldly with the weak. Both men and women possess an abundance of sexual jealousy, and have, in addition, the quick sensitiveness about rank, worldly possessions, and precedence which with us has become the reproach of the feminine. Lastly, they have, in its highest development, the capacity to make a volte-face with grace and equanimity. They are cunning, but not shrewd; their reasoning is wholly deductive, they are inclined to an enthusiastic assent to large statements, especially when these take the form of moral or political truisms; but they do not submit their convictions to practical working tests. They seem often inconsistent, but observation will show that, however inconsistent their practice is with their professions, it is always consistent with their pride, as I have analyzed it in these pages. 


\section{CHAPTER NINE}

\section{MY EARLY EXPERIENCES IN HOUSEKEEPING}

I SET UP HOUSEKEEPING - ROMOLDO'S IDEAS OF ARRANGING Furniture - My Cheerful Environment - Romoldo's Success in making "Hankeys" - He introduces the Orphan Tikkia as his Assistant - The Romance of RoMOLDO AND TIKKIA.

$\mathrm{T}$ the period of my advent in Capiz there were
but two other American women there, wives
of military men. Later our numbers were increased by the wives of several civilian employees and two more women teachers. In those first days the hospitality of the military women made no small break in the routine of my daily life. At the time of our appointment we teachers had been assured by a circular from the War Department that we should enjoy the privileges of the military commissary; but this ruling had been changed in the several months that had elapsed, and I found myself stranded with practically no access to American tinned fruits and vegetables. I ate rice, fish, and bananas with the best grace I could; and when, after a month of boarding, I decided to set up housekeeping, and one of these ladies surreptitiously and with fear and trembling presented me with a can of concentrated lye, my grati- 


\section{IMPRESSIONS OF THE PHILIPPINES}

tude knew no bounds. My Filipino servant, named Romoldo, whom I had dubbed "The Magnificent," was set to work cleaning up my prospective dwelling; and I went out and secured the services of a trooper of the Tenth Cavalry to supplement the deficiencies in Romoldo's housecleaning instincts by some American brawn and muscle.

The trooper, a coal-black African, had picked up a great deal of Spanish, which he spoke with the corruption of vowel sounds peculiar to his race and color. In addition to collecting the stipend agreed upon, he incidentally borrowed two dollars (U. S.) of me. Now, I was brought up in Missouri and knew enough of the colored race to be sure that I was bidding a fond adieu to the two dollars when I handed them to the trooper. But I was not prepared for my henchman's persistence in having the extension of time made formal. I was willing to forget the two dollars and have done with them, but the African would not permit them to rest in peace. He presented himself regularly every two weeks to ask for another fortnight's extension. Finally, when the regiment was about to leave the Islands, I insisted that he should accept the two dollars as an evidence of my good-will toward the United States Army and the defenders of the flag, and he was graciously pleased so to do.

The trooper's muscles were strong as his habits of renewal, and he and Romoldo scoured the floors of my new establishment until the shiny black accretions of twenty-five years of petroleum and dirt had 
given way to unpolished roughness, and then I set to work to get a new polish. Then we took hold of the furniture - heavy, wooden, Viennese stuff - and scrubbed it with zeal. My landlord came to look in occasionally and was hurt. He said plaintively that they had had no contagious diseases, and he asked why this deluge of soap and water. I basely declined to admit the flat truth, which was that the floors and chairs were too greasy for my taste, but attributed our energy to a mad American zeal for scouring. He said, "Ah, costumbre!" and seemed to feel that the personal sting of my actions had been removed.

In due time the house was clean, and I moved in. The sala, or drawing-room, was at least forty by thirty feet, with two sides arcaded and filled with shell windows, which, when drawn back, gave the room almost the open-air effect of a gallery. It was furnished with two large gilt mirrors, a patriarchal cane-seated sofa, several wooden armchairs, eleven majolica pedestals for holding jardinières, and two very small tables. These last-named articles "the Magnificent" placed at the head of the apartment in such a position as to divide its cross wall into thirds, and then arranged all the chairs in two rows leading from the two tables, beginning with the most patriarchal armchair and ending with the dining-room chair, the leg of which was tied on with a string. The effect was rigidly mathematical; and when my landlady came in and adorned each table with a potted rose geranium, stuck all over with the halves of empty egg-shells to 


\section{IMPRESSIONS OF THE PHILIPPINES}

give it the appearance of flowering, I felt that it was time to assert myself. The egg-shells went promptly into the garbage box, and the chairs and tables were pulled about to achieve the unpremeditated effect of our own rooms. Then I went out for a walk, and returning found that Romoldo had restored things to his own taste. Again I broke up his formation, so the next time he tried a new device. He put one table at the top of the room and one at the bottom, with the chairs arranged in a circle around each one. This gave the pleasing impression to one entering the room that a card game was ready to begin. Again Romoldo's efforts were treated with contempt.

For at least two weeks a deadly combat went on between Romoldo and me, in which I finally came off victor. At the end of that time he seemed to have accustomed himself to our ideas of decoration. He had, in our week's deluging, cleaned up the lamps of the chandeliers, brushed down the cobwebs, and removed some half-dozen baskets of faded and dust-laden paper flowers. $\mathrm{He}$ administered the ironical consolation meanwhile that their destruction did not matter, since my admiring pupils would see that the supply was renewed. To my eternal sorrow he was a true prophet, and I had to contemplate green chrysanthemums and blue roses, and a particularly offensive hand-painted. basket made of plates of split shell. However, the potted palms and ferns with which I ornamented the eleven pedestals made atonement; and when I came in after a hard day's work and saw the unreal, goldentinted light of afternoon filling the dignified old room, 
I found it home-like and lovely in spite of the paper flowers and the shell basket.

My bedroom was half as large as the sala, with a small room adjoining it which I used for a diningroom, and at the back there were a kitchen, a bathroom, closets, and a bamboo porch. For this shelter, furnished as it was, I paid the munificent sum of twenty-five pesos Mexican currency, or twelve and one-half dollars gold per month.

As my house was located over the second saloon in town - one of the regular, innocent, grocery-looking Filipino breed - and as it commanded a fine view of the plaza, guard mount, retreat, and Sunday morning church procession, I had at least all the excitement that was going in Capiz. The American soldiers swore picturesquely over their domino and billiard games down stairs; the "ruffle of drums" (though why so called I know not, for it consists of a blare of trumpets) woke up the sultry stillness at nine A. M.; the great church-bells struck the hours and threw in a frenzy of noise on their own account at some six or eight regular periods during the day; at twelve, noon, the village band stationed itself on the plaza to run a lively opposition to the bells; and at sunset the charming ceremony of retreat brought us all out to see the flag drop down, and to hear the clear, long bugle notes; and there were sick call, mess call, and several other calls. Not the least beautiful of these was "taps." I used to wait for it in the perfect stillness of starlit nights when the Filipinos had all gone to bed, and the houses were ever so faintly revealed by the lanterns 


\section{IMPRESSIONS OF THE PHILIPPINES}

burning dimly in front, and the faintest gleam told where the river was slipping by. There would be no sound save the step of the trumpeter picking his way up the street. Then the church clock would strike not the ordinary bell, but a deep-throated one that could have been heard for miles - and as the vibrations of the last stroke died away, the first highpitched, sweet notes would ring out, to fade away in the ineffable sadness of the closing strain.

But if there was much that was novel and more that was noisy in those first experiences, there was also plenty of irritation. As I stated before, I had brought Romoldo from Iloilo to Capiz with the idea of using him for a cook. In the days when I was still boarding, he had confirmed me in this intention by stating that he had had experience in that line with an American army officer. He was particularly enthusiastic over his achievements with "hankeys." For a long while, I could make nothing of this word, but at last I discovered that it was his corruption of "pancakes." I found out this fact by asking Romoldo to explain how he made "hankeys," and by recognizing among his ingredients milk, eggs, and flour.

As the Filipina with whom I boarded professed to be eager to learn American cookery, I told Romoldo to make some "hankeys." In the language of Virgil, I "shudder to relate" what those "hankeys" were. There were three, nicely piled on top of one another, after our time-honored custom. No words could fitly describe them. They resembled unleavened bread, soaked in a clarifying liquid, heated, pressed down, and 
polished on both sides. The Filipina tried to conceal her disgust, and pretended to accept my explanation that they were only a caricature of our loved breakfast delicacy; but I could see that she thought I was trying to cover up my newly acquired sense of national deficiency.

However, when I set up housekeeping, Romoldo was promoted to the office of chief cook and only bottle washer. He conveyed to me a delicate intimation that it was not proper for me to live without a female attendant, and said that he had a friend - a young woman lately orphaned - who needed work and would be glad to have the position. I was sufficiently unsophisticated in Filipino ways to take this statement at its face value. As the orphan was willing to labor for a consideration of one dollar gold per month and room, the experiment could not be an expensive one.

The orphan duly arrived, escorted by Romoldo. He carried her trunk also, consisting of several garments tied up in a cotton handkerchief.

Her name, as Romoldo pronounced it, was Tikkia (probably Eustaquia), and I could have wished she had been handsomer and younger. She was a heavybrowed, pock-marked female, with a mass of cocoanutoiled tresses streaming down her back, and one leg, bare from the knee down, rather obtrusively displaying its skinny shin where her dress skirt was looped up and tucked in at the waist. She had no petticoat, and her white chemisette ended two inches below the waist line. As it was not belted down, it crept out and lent 


\section{IMPRESSIONS OF THE PHILIPPINES}

a comical suggestion of zouave jacket to the camisa, or waist, of sinamay (a kind of native cloth made of hemp fibres). She understood not one word of Spanish or English.

When I occupied my new home for the first night, I "ordered" fried chicken and mashed potatoes for dinner, and then went out in the kitchen and cooked them. The army quartermaster had loaned me a range. Romoldo displayed an intelligent interest in the cooking lesson, but Tikkia seemed bored. When the potatoes were done, I gave them to Tikkia to mash. Romoldo was in the dining-room, setting the table. I told her in my best mixed Spanish and Visayan to mash them, and then to put them on the stove a few minutes in order to dry out any water in them. She understood just that one word "water"; and when I returned, after being out of the kitchen a minute, the potatoes were swimming in a quart of liquid. So I dined on fried chicken.

For the first two or three weeks there were many ludicrous accidents in my kitchen and some irritating ones. But on the whole Romoldo took hold of things very well; and though my menu broadened gradually, it was not long before he had learned a few simple dishes, and my labor of supervision was much lighter. I said that I was pleased with Romoldo to the enlisted man who was in charge of the officers' mess and who incidentally made some market purchases for me. He said, "You ain't particular," with a finality that left me no defence. He was mistaken, however. I am particular, but at that time I was still in the somnam- 
bulance of philanthropy which brought us pedagogues to the Philippines.

I am willing to admit to-day that I vastly overrated Romoldo's services, and yet, considering the untutored state of his mind and the extent of his salary, they were a good investment. There has been among some Americans here a carping and antagonistic spirit displayed toward Filipinos, which reflects little credit upon our national consistency or charity. We have a habit of uttering generalities about one race on the authority of a single instance; whereas, with our own, the tendency is to throw out of consideration those single instances in which the actual, undeniable practice of the American is a direct confutation of what his countrymen declare is the race standard. My kitchen under Romoldo's touches was not perfect, but I have seen worse in my native land.

Romoldo being a young and rather attractive man, and Tikkia such a female pirate, I insist that my failure to suspect a romance is at least partially justified; and certainly never by word or glance did they betray the least interest in each other. But some days after my establishment had begun to run smoothly, one of the military ladies asked me to dinner. The punkah string was pulled by a murderous-looking ex-insurrecto, who fixed me with a basilisk glance, half entreaty, half reproach. It became so painful that toward the end of dinner I asked my hostess if his expression was due to his general frame of mind or to a special aversion toward pedagogues. She replied that he was probably bracing himself to approach me on a topic consuming 


\section{IMPRESSIONS OF THE PHILIPPINES}

his very vitals, or as much of them, at least, as may be expressed in absent-mindedness. Tikkia was his matrimonio, and I, the maestra, had taken her and given her to Romoldo, and the twain lived in my house! The lady added that Tikkia was not matrimonio en iglesia - that is, married in church - but only matrimonio pro tem.

Pedro came into the sala after dinner and made his petition with humility. He extolled his kindness to the ungrateful Tikkia, and denounced Romoldo as a fiend and liar. He tried hard to weep, but did not succeed.

$O$ tempora! $O$ mores! Such are the broadening effects of travel and two short months in the Orient. Conceive of the old maid schoolteacher in America assuming the position of judge in a matrimonial - or extra-matrimonial - scandal of this sort.

I promised justice to the sniffling Pedro, and told him to call for it next day at ten A. M. Like me, he supposed it would take the form of Tikkia. But when I reached home and summoned the culprits before the bar of a "moral middle class," they were not disconcerted in the least. Romoldo stood upon high moral ground. Tikkia might or might not be married. It was nothing to him, and he did not know. She was an orphan of his acquaintance to whom he wished to do a kindness. Tikkia promptly drew up her skirt over the unexposed knee and showed a filthy sore which she said was caused by Pedro's playful habit of dragging her about on stony ground by the hair. Moreover she stood upon her legal rights. She was not matrimonio 
en iglesia, and she had a right to leave Pedro when she chose.

Pedro came next day at ten A. M., but he did not get justice. On the contrary, justice, as embodied in Tikkia, stood at the head of the stairs and said, "No quiero" as often as I (and Pedro) turned our imploring eyes upon her.

Things went on in this way for some time, and my perplexities offered amusement to my friends. I felt sure that Romoldo and Tikkia were lying, and at one time I resolved to discharge them both. The young American teacher who had been in the Islands since the beginning of our occupation gave me some sound advice. He said: "What on earth are these people's morals to you? Romoldo is a good servant. He speaks Spanish, and if you let him go for one who speaks only Visayan, your own housekeeping difficulties will be greatly increased." Then I pleaded the old-fashioned rural American fear that people might think the worse of me for keeping such a pair in my employ; and Mr. S- simply collapsed. He sat and laughed in my face till I laughed too. "We are not in America now," was his parting remark; and I am still learning what a variety of moral degeneration that sentence was created to excuse.

I have already given more space than is warranted by good taste to the romance of Tikkia and Romoldo. The affair went on till I began to fear lest Pedro, in one of the attacks of jealousy to which Filipinos are subject, should take vengeance and a bolo in his own hands. Fortunately, at the critical moment, Romoldo 


\section{IMPRESSIONS OF THE PHILIPPINES}

and Tikkia fell out. She kicked his guitar off the back porch and he complained that she neglected her work. Then she asked leave to return to her own town for a few days, and the request was joyfully granted. Pedro also obtained a vacation. Their town was round the corner one block away, and there they retired. They greeted me pleasantly whenever I passed by, and Tikkia secmed in no wise embarrassed by her change of front.

If I have described this incident in full, it is because it illustrates so perfectly the attitude of a large portion of the Filipino people on marriage. The common people seldom marry except, as we would term it, by the common-law marriage. When they do marry in church, it is quite as much for the éclat of the function as for conscientious reasons. Marriage in the church costs usually eight pesos (four dollars gold), though cheaper on Sundays, and to achieve it is quite a mark of financial prosperity.

Of course, among the educated classes our own view of marriage prevails, though I have heard of instances where the common-law form was still observed. In some towns it is customary for marriages to take place but once a year; an American told me of descending on a mountain town where the annual wedding festival was due, and of finding fifty-two happy couples in their gala attire wending a decorous procession toward the church. 


\section{CHAPTER TEN}

\section{FILIPINO YOUTHS AND MAIDENS}

Manners and Social Condition of Filipino Girls - Sentimental Boy Lovers - Love-making by ProXy - How Courtship is usually performed - Premature AdoLescence of Filipino Youth - The Boda AmericanaFilipino Girls are Coquettes, but not Flirts - Exposure of Filipino Girls to Unchaste Conversation Unceasing Watchfulness over Girls - Progressive Changes in all the above Matters.

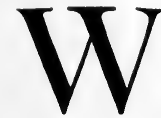

ITH regard to their women the Filipinos are an Occidental people rather than an Oriental one. Marriage is frequently entered upon at the will of the parent, but few parents will insist upon a marriage where the girl objects. While the social liberty accorded a young girl is much less than what is permitted in our own country, there is no Oriental seclusion of women. Children accompany their parents to balls and fiestas, and maidens are permitted to mingle freely in society from their babyhood. At fourteen or fifteen they enter formally into society and begin to receive attentions from men. In the upper classes seventeen or eighteen is the usual time for marriage. By the time a girl is twenty-two or twenty-three she is counted passée, and, if unmarried, must retire into the background in favor of her younger sisters. 


\section{IMPRESSIONS OF THE PHILIPPINES}

The young girls are exceedingly attractive. They are slender, and their heads sit beautifully above long swan-like necks. They dress their hair in a rather tightly drawn pompadour, and ornament it with filigree combs set with seed pearls, or, if they are able, with jewelled butterflies and tiaras. Jewellery is not only a fashion here, but an investment. Outside of Manila, Iloilo, and Cebu, banks are practically unknown. The provincial man who is well to do puts his money into houses and lands or into jewellery for his womankind. The poor emulate the rich, and wear in imitation what their wealthy neighbors can afford in the real.

Filipino women never affect the dominating attitude assumed by young American coquettes. They have an infinite capacity for what we call small talk and repartee; and, as they never aim for brilliancy and are quite natural and unaffected, their pretty ways have all the charm that an unconscious child's have. They love dress, and in one lightning flash will take you in from head to foot, note every detail of your costume, and, the next day, imitate whatever parts of it please their fancy and fall in with their national customs. They are adepts at mimicry and among themselves will lash us mercilessly. They straighten up their shoulders, pull in the abdomen, and strut about with a stiff-backed walk and with their hands hanging stiffly at their sides. They themselves are full of magnetism and can advance with outstretched hand and greet you in such a way as to make you believe that your coming has put sunshine in their lives.

Their chief talk is of lovers in the two stages of 

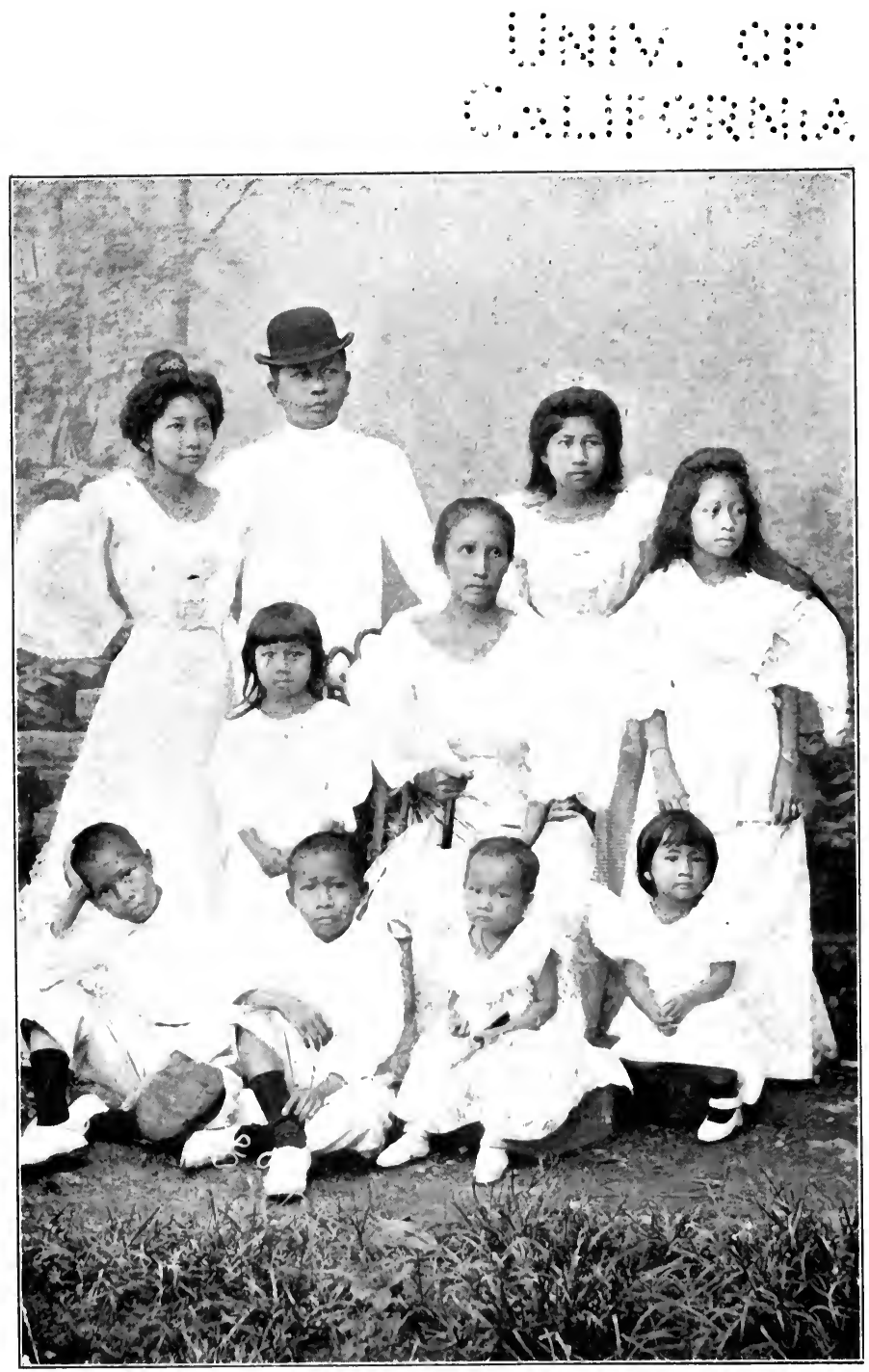

A FILIPINO MOTHER AND FAMILY

All the children except the baby attended the public school 

pretendiente and novio, and they are full of hints and imputations to one another of love affairs. Among young people, in spite of the restrictions put about them to keep the opposite sexes from meeting tête-àtête or the remotest chances of "spooning," the air is surcharged with romance. Apparently the Filipino boy has no period in his development in which he hates girls. At twelve or fourteen he waxes sentimental, and his love notes are the most reeking examples of puppy love and high tragedy ever confiscated by an outraged teacher. When written in the vernacular they are not infrequently obscene, for one of the saddest phases of early sentiment here is that it is never innocent; but in English they run to pathos. One ludicrous phase of love-making is the amount of thirdperson intervention - an outsider thrusting himself into the matter to plead for his lovelorn chum. For some years I made a collection of confiscated billetdoux, but they were destroyed in one of the frequent fires which visit Manila. I can, however, produce a fair imitation of one of these kindly first aids to the wounded. This is the prevailing style:

\section{Miss —,}

Lovely and Most Respectable Lady:

I am do me the honor to write to you these few unworthy lines to tell you why you are breaking the heart and destroying a good health of my friend Pedro. Always I am going to his house every night, and I am find him weeping for you. He is not eating for love of you. He cannot sleep because he is think about your eyes which are like the stars, and your hairs which are the most beautiful of all the girls in this town. Alas! my 


\section{IMPRESSIONS OF THE PHILIPPINES}

friend must die if you do not give him a hope. Every day he is walking in front of your house, but you do not give to him one little word of love. Even you do not love him, you can stop his weep if you like to send him one letter, telling to him that you are not angry to him or to me, his friend.

I have been informed by several persons that there is an official etiquette about this sort of correspondence. When a boy decides that he has fallen in love with a schoolmate or with any other young girl, no matter whether he knows her or not, he writes her a letter in the first person similar to the above. If she ignores the letter utterly, he understands that he does not please her - in brief, that "No Irish need apply." But if she answers in a highly moral strain, professing to be deeply shocked at his presumption, and informing him that she sees no way to continue the acquaintance, he knows that all is well. He sends her another letter, breathing undying love, and takes steps to be introduced at her home. Once having obtained a calling acquaintance, he calls at intervals, accompanied by seven or eight other young men, and, in the general hilarity of a large gathering, endeavors to snatch a moment in which to gaze into the star-like eyes of his innamorata, or to gloat over her "hairs which are the most beautiful."

The lover's habit of fortifying himself with the society of his fellow men would be the last which an American boy could understand. But a Filipino swain rarely presents himself alone at a house to call. He feels, perhaps, that it makes him conspicuous. The 
whole race, for that matter, is given to the habit of calling in droves. If a Filipino girl goes to an office on business, her mother and father do not constitute a sufficient escort. Her brothers, cousins, a few admirers, and possibly a female friend or two are added to the parental guardians, till the bodyguard assumes the appearance of a delegation large enough to negotiate a treaty. One of the division superintendents tells a story which shows the humorous American recognition of the inconveniences of this habit. The Superintendent had recommended two young girls as pensionadas, or government students, in the Manila Normal School. It was their duty, on arriving in Manila, to report to the Director of Education; and they must have done so in the usual force, for the Director's official telegram, announcing their arrival, began in this pleasing strain: "Miss —_ and Miss —. with relatives and friends, called this morning."

The premature adolescence of the Filipino youth makes him very repellent to the American. One of the most frightful things which I ever saw was a play given in Spanish by children. The play itself was one which Americans would never have permitted children to read or to see, much less to present. The principal character was a debauched and feeble old man of the "Parisian Romance" type; it was played by a nineyear-old boy, who made the hit of the evening, and who reminded me, in his interpretation of the part, of Richard Mansfield. His family and friends were proud of his acting, which was masterly, and laughingly declared that his conception of the role was wholly his 


\section{IMPRESSIONS OF THE PHILIPPINES}

own. If so, there was no need of laughter and there was much cause for tears.

Here is a short essay written by a twelve-year-old boy, in response to an order to write a composition about what he had done the previous day.

"Yesterday I called upon all my young lady friends. None but the fathers appeared. We must all be judged according to our works."

The child wrote this by constructing the first sentence himself, and by picking the other two out of phrase-books, which from some source or other are scattered all over the Philippine Islands. What he meant to convey in the carefully pieced mosaic was that he was a dangerous fellow, and that when he came around the fathers kept a close eye on their daughters. That is dubious wit in a man of thirty. In a child of twelve it is loathsome.

Engagements are usually announced at once and are seldom long - from three weeks to three or four months. If the marriage is really for love, as is not infrequently the case, the lovers must have a hard time of it; for they never see each other alone, and "spooning" before others would seem to them in the last degree scandalous. They have marvellous selfcontrol. I have watched many a pair of Filipino lovers for the stolen glances, the shyness, the everpresent consciousness of each other which are characteristic of our lovers, and I have never beheld the faintest evidence of interest in any engaged or newly married couple. They manage to preserve an abso- 
lutely wooden appearance at a time when one would expect a race so volatile to display its emotions freely.

Elopements sometimes take place and are called the boda Americana, or American marriage. However, they have the advantage of us in one kind of elopement that of the widow. Runaway marriages between widows and old bachelors are not a common feature of American life, but they seem to constitute the most frequent form of elopement here. Forced marriages occur in spite of the restrictions put around young girls. They cause a ten days' hubbub, winks, nods, and much giggling behind fans. But no social punishment and ostracism of the girl follows as in our own country. So long as the marriage is accomplished, the Filipinos seem to feel that the fact of its being a little late need disturb no one. But if, as sometimes happens, a girl is led astray by a married man, then disgrace and punishment are her lot. I recall a circumstance where a young girl under a cloud left her native town, never to appear there again. But less than three months after her banishment, her seducer was an honored guest, sitting at the right hand of her brother, in the brother's own house. Apparently the best of feeling prevailed over a matter that with us could never have been forgiven, though bloodshed might perhaps have been averted.

In my eight years in those Islands I have met among the upper classes but one young girl whose conduct offered reason to men to take her lightly. In a pretty, childish way, Filipino girls are coquettes, but they are not flirts. Their conception of marriage and of their 


\section{IMPRESSIONS OF THE PHILIPPINES}

duty to their own husbands and their children is a high and noble one. Nevertheless, with innately good and pure instincts, they cannot take half as good care of themselves as can the American girl who is more indiscreet, who knows much less of the matters pertaining to love and sex. The latter has an infinite advantage over her dusky sister in the prudery of speech which is the outwork in a line of fortifications in which a girl's tenacity to her own ideal of chastity must be the final bulwark. A frankness of speech prevails in the Philippines with regard to matters about which we are frank under necessity, but which, as far as possible, we slide into the background. Stories are told in the presence of young girls, and jokes are interchanged, of more than questionable nature according to our standards. Our prudery of speech is the natural result of the liberty permitted to women. When the protection of an older woman or of a male relative is done away with, and a girl is permitted to go about quite unattended, the best and the surest protection that she can have is the kind of modesty that takes fright at even a bare mention, a bare allusion, to certain ordinarily ignored facts of life.

The result of general freedom of speech and the process of safeguarding a girl from its results is to make a Filipino girl regard her virtue as something foreign to herself, a property to be guarded by her relatives. If, through negligence or ignorance on the part of her proper guardians, she is exposed to temptation, she feels herself free from responsibility in succumbing. Such a view of life puts a young girl at a great dis- 
advantage with men, especially with men so generally unscrupulous as Filipinos.

Among the lower classes there is no idea that a young girl can respect herself or take care of herself. Girls are watched like prisoners, and are never allowed to stray out of the sight of some old woman. It is almost impossible for an American woman to obtain a young girl to train as a servant, because, as they say, we do not watch them properly. This jealous watching of a child's virtue is not, however, always inspired by the love of purity. Too frequently the motive is that the girl may bring a higher price when she reaches a marriageable age, or when she enters into one of those unsanctified alliances with some one who will support her. Filipino men are merciless in their attitude toward young lower-class girls, not hesitating to insult or annoy them in the most shameless way. I once forced a little maid of mine to wear the regular maid's dress of black, with muslin cap and apron, and she was certainly a joy to the eye; but one day I sent her out on an errand, and she came back almost hysterical under the torrent of ribald admiration which my thoughtlessness had brought upon her. A seamstress will not remain alone in your house while you run into a neighbor's on an errand without bolting herself in the room; and, if you are to be gone any length of time, she will not stay there at all, simply because she is afraid of your men servants - and justly so.

However, in respect to such matters, things are changing fast. The Filipinos who love us least, high 


\section{IMPRESSIONS OF THE PHILIPPINES}

or low, rich or poor, admit that the American idea of treating every self-respecting woman with respect is a good thing. They remark frequently the difference between now and former times, and say, with admiration, that a woman can go past the cuartels, or the fire stations, without encountering insult in the form of galanteria; and the electric street-car line, suspected at first, has gained the confidence of nearly all. Many Filipino families of the upper class permit their daughters to go to and from the American schools on the trolley car, and it is no uncommon thing to see three or four youngsters, all under ten, climbing on and off with their books, asking for transfers, and enjoying their liberty, who ten years ago would have been huddled into a quilez and guarded by an elderly woman servant.

Lastly, a bill for female suffrage was introduced into the Philippine Assembly a few weeks ago. It is one of those "best" things which Filipinos all want for their land. The young man who introduced it had probably been reading about the female suffragist movement in England, and he said to himself that it would be a fine idea to show this dull old world how progressive and modern are the Philippine Islands; and so he drafted his bill. Nothing seems to have been heard of it, and it was probably tabled, with much other progressive legislation, in the hurry of the last days of the session. Another bill was one to put an annual license of one thousand pesos (five hundred gold dollars) on every minister of the gospel, Protestant or Catholic. I suspect its parent of having been coached up on 


\section{FILIPINO YOUTHS AND MAIDENS 129}

modern French thought. However, that is not pertinent to the woman question. What I desire to do is to give a correct impression of a country where real conditions are such as I have described them, and ideal conditions have advanced to the point of a bill for female suffrage. 


\section{CHAPTER ELEVEN}

SOCIAL AND INDUSTRIAL CONDITION OF THE FILIPINOS

American and Tagalog Invaders of Visaya compared Doubt as to the Aptitude of Filipinos for Self-government - Their Civilization Not achieved By themselves but inherited from Spain - Their Present Personal Liberty - Belief of the Poor that Alien Occupation is the Root of their Misery - How the Filipinos view Labor - Their Apathy toward Machinery - Their InTEREST CENTRED NOT IN INDUSTRY BUT IN Themselves Their Hazy Conceptions of Government - Their Need of a Remodelled Social System - Their Jealousy Lest Others make Large Profits in dealing with them Zeal of the Aristocrats to preserve their Prerogatives - A New Aristocracy likely to be raised by the American Public Schools.

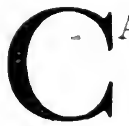

APIZ was occupied by a company of the Tenth Cavalry and one of the Sixth Infantry. The relations between Americans and Filipinos seemed most cordial. There had never been any fighting in the immediate neighborhood of the town. The Visayans are a peaceful race; even in the insurrection against Spain the Capizeños felt a decided proSpanish sentiment. Early in the rebellion a few boat-loads of Tagalog soldiers came down from Luzon, and landed on the open north coast two miles from the town. The valiant Capizeños had dug some trenches on the beach and had thrown up a breastwork there, and they went out to fight for Spain and Visaya. They fired two rounds without disconcerting the Tagalogs 
very much, and then, having no more ammunition, they "all ran home again," as my informant naïvely described it. The Tagalogs took possession of the town, and the Visayans lived in fear and trembling. Nearly all women, both wives and young girls, carried daggers in fear of assault from Tagalog soldiers. Some declared to me that they would have used the daggers upon an assailant, others told me that the weapons were intended as a last resort for themselves. The Spanish wife of our Governor said that during the time of Tagalog occupation she seldom ventured out of her home; that she discarded her European dress, affected the native costume, wore her hair hanging down her back, and tried in every way to keep from attracting the attention of the invaders. Neverthelessis, several young girls were seized in spite of their parents' efforts to protect them. Many families fled from the town and took refuge in the mountain villages inland. Others lived in boats, lurking about the rivers and the innumerable waterways which criss-cross the swampy coast plain. When the Tagalogs withdrew, the wanderers returned to their homes, only to make a fresh exodus when the Americans came.

- The Americans did not land on the north coast, but entered the town from the south, having marched and fought their way up the full length of the island from Iloilo. Horrid rumors preceded them concerning their gigantic size and their bloodthirsty habits. It was reported that they had burned hundreds of women and children alive at Iloilo. The timid Capizeños had no idea of resistance, but, for the most part, closed 


\section{IMPRESSIONS OF THE PHILIPPINES}

their houses, leaving some old servant in charge, and took once more to the hills and the swamps. A few sage heads had their own reasons for doubting the alleged American ferocity, and decided to stay at home and risk it.

One of my pupils, a very intelligent young girl, described to me the American entry. She said that the houses of the rich were closed, shell windows were drawn to, and the iron-sheathed outer doors were locked and barred. But most shell windows have in the centre a little pane of glass to permit the occupants of the house to look out without being seen. My young friend told me how her family were all "peeking," breathless, at their window pane, and how the first view of the marching columns struck fear to their hearts, so tall and powerful seemed the well-clad, well-armed men. At hal was called, and after the proper formalities at the provoste, or town hall, the municipality was handed over to American rule, and the Stars and Stripes floated from the local flagstaff. The soldiers were permitted to break ranks, and they began buying fruits and bottles of beer and of native wine in the tiendas, or shops. The soldiers overpaid, of course, joked, picked up the singleshirted pickaninnies, tossed them, kissed them, and otherwise displayed their content. Then, said my informant, her father (who is an astute old fellow) decided that the story of American ferocity was a lie. He ordered his house opened, and the shell windows slid back, revealing his pretty daughters in their best raiment, smiling and bowing. The officers raised their caps and gave back smiles and bows; a few natives 


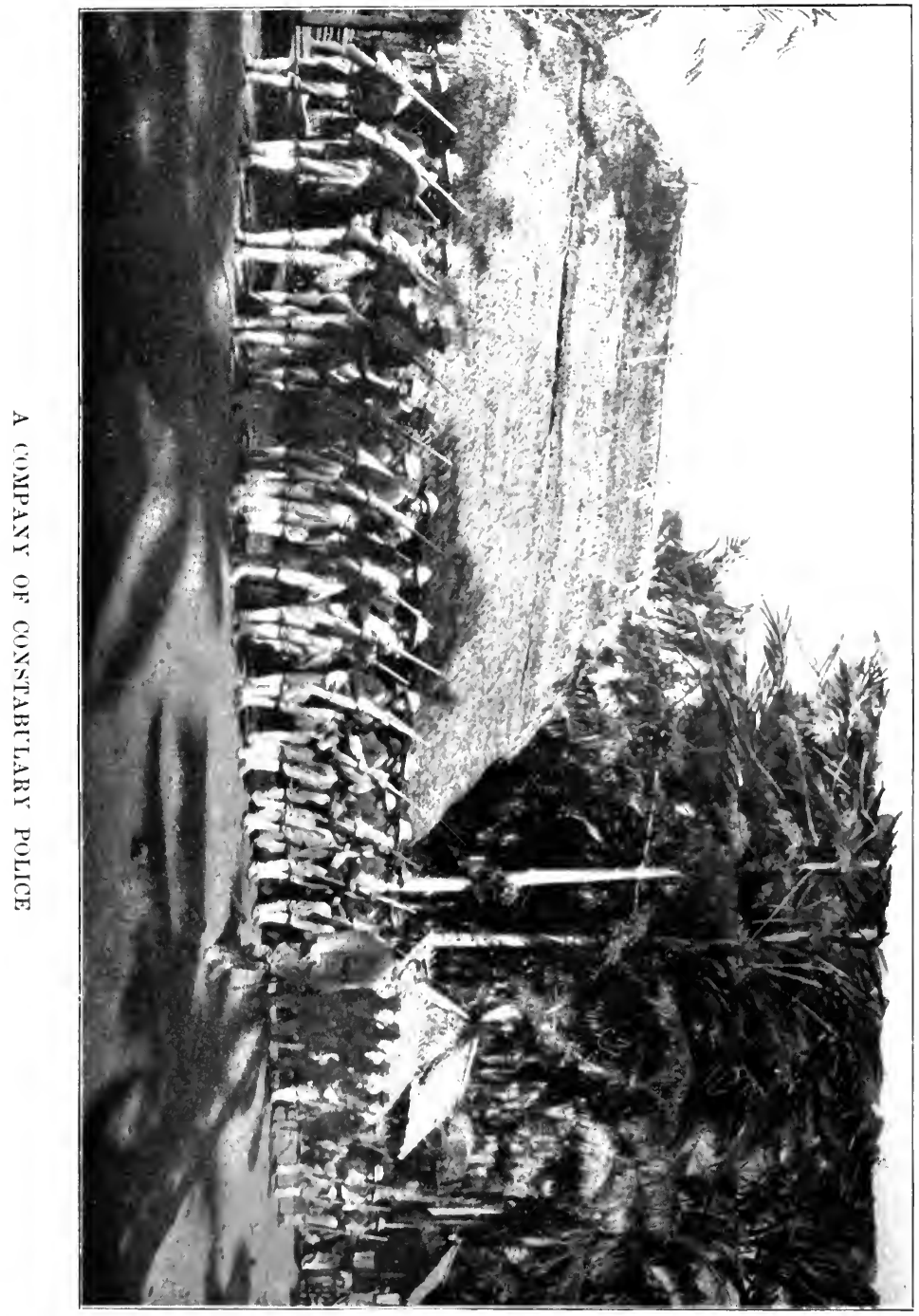


$\because \cdots \because a_{1} \therefore \ldots \vdots \vdots \ldots$ 
cried, "Viva los Americanos," and behold, the terrible event was all over.

Acquaintance was at once struck up. The officers came to pay their respects, drank beer and muscatel, consumed sweets, and paid florid compliments in Spanish. They began to take possession of those houses whose owners were out of town, and the news went out. Then there was as great a scramble to get back as there had been to get away. In a few days everything was running smoothly, and, as my interlocutor remarked, all the American officers were much in love with the charming Filipino girls.

Almost the first act of the military was to open the schools. The schoolhouses had been used as barracks by the Tagalogs. The chaplain of the Eighteenth Infantry, the children told me, was their first teacher. The opening of the schools was a great surprise to the Filipinos, who were clever enough to appreciate the national standards which the act implied.

At the time of my arrival the foregoing facts were, in the rush of events, almost ancient history. Two years had passed. American women, wives of officers, had come and gone. Peace had been declared and the machinery of civil government had been put in action.

It would be foolish for me to spend time discussing the Filipino's aptitude for self-government. Wiser heads than mine have already arrived at a hopeless impasse of opinion on that point. There are peculiarities of temperament in the Filipino people which are seldom. discussed in detail, but which offer premises for statements and denials, not infrequently acrimonious, and 


\section{IMPRESSIONS OF THE PHILIPPINES}

rarely approached in a desire to make those judging from a distance take into consideration all that makes opinions reliable. Such peculiarities of character seem to me pertinent to a book which deals with impressions.

Whatever their capacity for achieving the AngloSaxon ideal of self-government, it ought to be recognized that the Filipinos are both aided and handicapped by receiving not only their government but their civilization ready made. Their newly aroused sense of nationality is asserting itself at a period in the world's development when the mechanical aids to industry and the conscience of a humane and civilized world relieve Filipino development from the birth throes by which other nations have struggled to the place at which the Filipinos begin. Thus, at the same time that individuals are spared the painful experiences which have moulded and hardened the individual units of other races, the Filipinos have, as a race, received an artificial impetus which tends to deceive them as to their own capacity, and to increase their aggregate self-confidence, while the results of personal ineptitude are continually overlooked or excused.

Both civilization, as acquired in the three hundred years of Spanish occupation, and self-government have descended upon the Filipino very much as the telephone and the music box have done - as complete mechanisms which certain superficial touches will set in motion, the benefits of which are to certain classes and individuals quite obvious, and the basic principles of which they have memorized but have not felt. At present there are not, in the emotional being of the 
Filipinos, the convictions about liberty and-government which are the heritage of a people whose ancestors have achieved liberty and enlightenment by centuries of unaided effort, and who are willing to die - die one and all - rather than lose them; and yet there is a sincere, a passionate desire for political independence. The Filipino leaders, however, have no intention of dying for political independence, nor do they desire to sacrifice even their personal pleasures or their effects. They talk a great deal about independence, they write editorials about it, it fills a great part of their thoughts ; and no reasonable person can doubt their sincerity. But most of the political talk in the Philippines is on a par with certain socialistic thought in the United States - the socialistic talk of modern writers and speakers, of idealists and dreamers. It seems as great a perversion of abstract justice, to a Filipino, that an alien nation should administer his Government, as it seems to a hard-working American woman that she should toil all her life, contributing her utmost to the world's progress and the common burden of humanity, while her more fortunate sisters, by the mere accident of birth, spend their lives in idleness and frivolity, enriched by the toil of a really useful element in society. But to most Filipinos, as to most American women, the contemplation of the elemental injustice of life does not bring pangs sufficient to drive them into overt action to right the injustice. There are a few Filipinos upon whom the American administration in the Philippines presses with a sense of personal obstruction and weight heavy enough to make them desire overt_action; 


\section{IMPRESSIONS OF THE PHILIPPINES}

but upon the majority of the race the fact of an alien occupation sits very lightly. No man, American or Filipino, wants to risk his life for the abstract principles of human justice until the circumstances of life growing out of the violation of those principles are well-nigh unendurable to him. The actual condition of the Philippines is such that the violation of abstract justice that is, alien occupation - does not bear heavily upon the mass of the people. For the entire race alien occupation is, for the time being, an actual material benefit. Personal liberty in the Philippines is as absolute as personal liberty in the United States or England. Far from making any attempt to keep the native in a condition of ignorance, the alien occupiers are trying to coax or prod him, by all the short cuts known to humanity, into the semblance of a modern educated

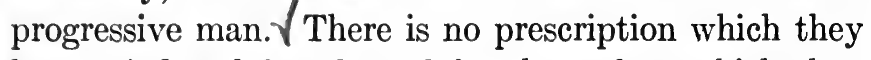
have tried and found good for themselves which they are not importing for the Philippines, to be distributed like tracts. And to the quick criticism which Filipinos of the restless kind are prone to make, that what is good for an American is not necessarily good for a Filipino, the alien occupiers may reply that, until the body of the Filipino people shows more interest in developing itself, any prescription, whether it originate with Americans or with those who look upon themselves as the natural guides and rulers of this people, is an experiment to be tried at the ordinary experimental risk.

The common people of the Philippine Islands enjoy a personal liberty never previously obtained by a class so rudimentary in its education and in its industrial 
development. They would fight blindly, at the command of their betters, but not because they are more patriotic than the educated classes. The aristocrats, who would certainly hesitate to fight for their convictions, really think a great deal more about their country and love it a great deal more than do the common people, who would, under very little urging, cheerfully risk their lives. But the poorer people live under conditions that seem hard and unjust to them. The country is economically in a wretched state, and the working-classes have neither the knowledge nor the ambition to apply themselves to its development. Unable to discover the real cause of their misery (which is simply their own sloth), they have heard just enough political talk to make them fancy that the form of government is responsible for their unhappy condition. With them the causes which drive men into dying for an abstract idea do exist; and it is easy for a demagogue to convince them that the alien occupation is the root of all evil, and that a political change would make them all rich.

Among the extremely poor of the Filipinos there exists a certain amount of bitterness against Americans, because they think that our strong bodies, our undoubtedly superior health and vitality, our manner of life, which seems to them luxurious past human dreams, and our personal courage are attributes which we enjoy at their expense. The slow centuries which have gone to our building up, mental and physical, are causes too remote for their limited thinking powers to take into consideration. Moreover, though we say that we 


\section{IMPRESSIONS OF THE PHILIPPINES}

have come to teach them to work and to make their country great, we ourselves do not work; at least, they do not call what we do work. A poor Filipino's conception of work is of something that takes him into the sun or that soils his clothing. Filipinos hate and fear the sun just as they hate the visible tokens of toil on their persons. Where they know the genteel trades such as hat weaving, dressmaking, embroidering, tailoring, and silversmithing, there is relatively a fair industrial willingness. Men are willing to be cooks and house servants, but they do not want to learn carpentry or blacksmithing or gardening, all of which mean soiled clothes and hot work; and women are unwilling to work in the kitchen. 'From the poor Filipinos' standpoint, the Americans do not work - they rule. It would be difficult to make a Filipino of the laboring class believe that a teacher or a provincial treasurer had done a day's work. Loving, as all Filipinos do, to give orders to others, ignorant as they are of the responsibilities which press upon those who direct, they see merely that we do not soil our hands, and they envy us without giving us credit for the really hard work that we do.

Meanwhile there pours in upon the country a stream of modern mechanism and of modern formulated thought, and the laborer has just as little real interest in knowing what is inside the machine as his slightly more intelligent neighbor has in examining the thought and in accepting or rejecting it on its merits. Some accept all that we offer them, doing so in a spirit of real loyalty, on the assumption that we know more than 
they do, and that our advice is to be accepted. Others reject everything with a blind resentment because it comes from our hands. They feel that, in accepting or rejecting, they are demonstrating their capacity to do their own thinking, when in reality they are only asserting their right to do their own feeling. A sense of discrimination in what they accept or reject in our thought has not yet appeared, to any great extent, in those classes of Filipinos with whom I have come in contact; nor as yet have I ever beheld in the laboring classes a desire to understand the mechanisms to which they are constantly introkuced, which will be the first symptoms of growth.

A few weeks ago a Filipino workman was making an electric light installation in my house. He handled the wires very carelessly, and I asked him if he was not afraid of a shock. On his replying that the current was very light, I put the inevitable American query, How did the company manage to get a light current on one street, and at the same time to keep up the current in other parts of the city? His reply was, "There is a box on Calle San Andres, and the current goes in strong on one side and comes out light on the other." On my asking if he knew how the box was able to produce such a result, he replied blithely that he did not know; and to a third question, why he did not try to find out, he asked me why he should want to know. He was a very ignorant man, but his attitude was not uncharacteristic of much wiser men than he. I discovered one morning, in talking to the most advanced class in the Manila School of Arts and Trades, that not one of them knew 
what steam is, or had any idea of how it is applied to manufacture ; and yet they were working every day, and had been working, most of them for two or three years, in the machine-shops and the wood-working shops where a petroleum engine was in constant operation. The boys had shown such a courteous interest in what was pointed out to them, and had so little real interest and curiosity in what they were working with, that their shop teachers had never guessed that they did not know the elementary principles of mechanics.

If a flying machine should suddenly descend in an American village with no sign of steam gear, electric motor, compressed air, or any other motive power with which we are familiar, can you imagine that eighty per cent of the population of the village would stand around, begging the inventor to make it fly and alight again, exhibiting all the delight of children in a strange toy, but giving it not one close glance, one touch to determine how it is made, and not even wondering anything about it? Can you imagine all those people placidly accepting the fact that there are other nations interested in making strange machines, and receiving the strange toy as an example of foreign energy with which, at that or at any other time, they had no concern? Yet such is the actual condition of affairs in the Philippine Islands, and I am not sure that my estimate of eighty per cent is not too low. Filipinos of the educated classes, gentlemen who can talk about

"The grandeur that was Greece, And the glory that was Rome,". 
or who can quote Tom Paine or Voltaire or Rousseau, or discuss the fisherman's ring of the Pope, or the possibilities of an Oriental race alliance, would give a glance at such a machine and dismiss it with such a remark as this: "Ah! a new flying machine. Very interesting. If it proves practical, it should be a great benefit to the Philippines. The Government should buy two or three and put them in operation to show the people how they can be used."

The great majority of the Filipino people are simply apathetic toward the material and spiritual appliances of their present status. (Please do not infer, however, that they are apathetic toward the status itself.) Fortune is continually thrusting upon them a ready-made article, be it of transportation, of furniture, of education, or even of creed. With no factories of its own, their land is deluged with cheap manufactured goods. With almost no authors, they have been inundated with literature and texts. With no experience in government, they have a complicated system presented to them, and are told to go ahead, to fulfil the requirements, to press the button, and to let the system do the rest. And they are, with few exceptions, making the mistake of assuming that their aptitude in learning to press the button is equivalent to the power of creating the system. They are like some daring young chauffeur who finds that he can run an automobile, and can turn it and twist it and guide it and control it with the same ease that its inventor does, and who feels that he is as fully its master - as indeed he is, till something goes wrong. 


\section{IMPRESSIONS OF THE PHILIPPINES}

The intelligent Filipinos who are pressing for immediate self-government have no intentions of changing the "press-the-button" system if they get what they want. Nor can the American Government, if it remain here, do any more than it is now doing to urge the Filipino into real industrial and mental activity. Until the Filipino takes more interest in things than he takes in himself; until he learns to approach life from some other standpoint than the social one, and with some other object than secing how large a figure he can cut in it, it makes no difference what flag flies over his head, his national existence is an artificial one, a semblance of living nourished by the selfishness of those with whom he has commercial relations.

The intelligent Filipinos (I speak of the ordinary middle classes of Manila and the provinces, not of the really eminent Filipinos who are associated with the Government, for with them I have little acquaintance) have had so little practical contact with the great world, so little conception of what a strong commercial and manufacturing nation is, that it is impossible to make them understand that no nation of the present day can achieve greatness except by industry. If you can get them to talk freely, you find them absorbed in a glorious dream of the Filipino people dazzling the world with pure intellectuality - a Philippines full of poets, artists, orators, authors, musicians, and, above all, of eloquent statesmen and generals. They do not reflect that a statesman is wasted who has nothing but a handful of underfed people to govern, and that it is commerce and agriculture which furnish the propel- 


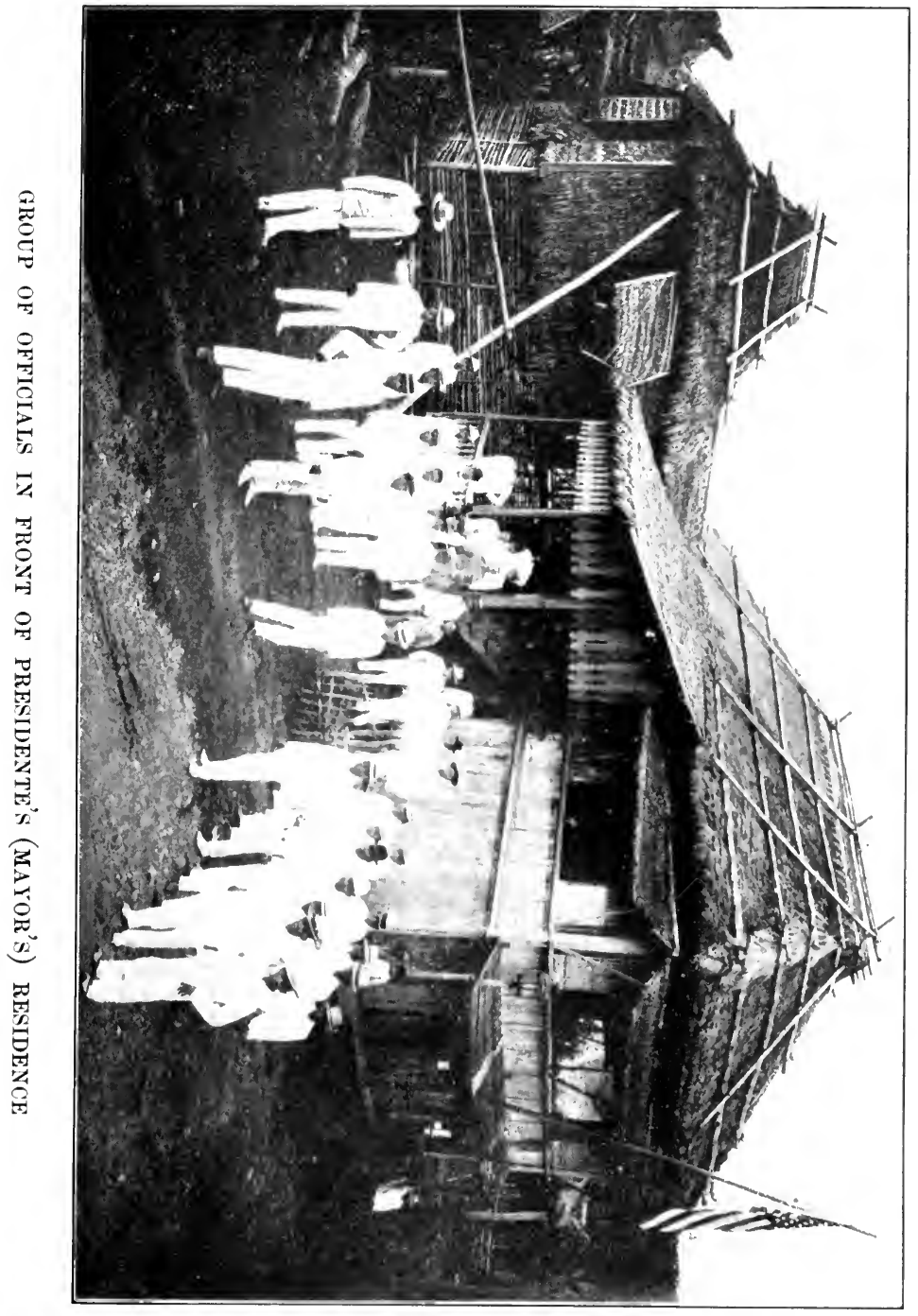



ling power to the ship of state on which the statesman is a pilot. They want to be progressive, and their idea of progress is a constant stream of mechanical appliances flowing like water into the Philippines from other lands; but they do not even consider where the money is to come from to pay for all the things they want. They howl like victims over taxation, but they have a hazy idea that it is the duty of their Government to seek out every labor-saving machine in the world and to buy it and to put it in operation in the Philippines till the inhabitants have accustomed themselves to its use, and have obtained through its benefits the wherewithal to indulge in more of the same sort. They do not concern themselves with the problem of the Government's getting the money to do all this, other than they think that if we Americans were out of the way, and the six or eight million pesos of revenue which go annually into our pockets were going to Filipinos instead, there would be money in plenty for battleships, deep-water harbors, railroads, irrigation, agricultural banks, standing armies, extended primary and secondary education; and that the resources of the Government would even permit of the repeal of the land tax, of the abolition of internal revenue taxes, and of the lowering of the tariff. One of their favorite dreams of raising money is to put a tremendously high license upon all foreigners doing business in the Islands; and so high an opinion have they both of their value to the world at large and of their prowess, that they do not take into consideration the probability of the foreigner's either getting 


\section{IMPRESSIONS OF THE PHILIPPINES}

out of the country or appealing to his own Government to protect his invested capital. When they speak of independence, they invariably assume that America is going to protect them against China, Japan, or any of the great colony-holding nations of Europe.

Such are the peculiar governmental conceptions of the middle-class Filipino - a class holding the ballot by the grace of God and the assistance of the American Government. Their inverted ideas come from real inexperience in highly organized industrial society, and from perfectly natural deductions from books. When they study Roman and Greek history, they learn there the names of generals, poets, artists, sculptors, statesmen, and historians. Books do not dwell upon that long list of thriving colonies which filled the Grecian archipelago with traffic, and reached east and west to the shores of Asia and to the Pillars of Hercules. The Filipinos learn that Rome nourished her generals and her emperors upon the spoils of war, but they do not reflect that the predatory age - at least in the Roman sense - is past. Their imaginations seize upon the part played by the little island republic of Venice, and they gloat over the magnificence of the Venetian aristocracy, but they hardly give a thought to the thousands of glass-blowers, to the weavers of silken stuffs, to the shipbuilders and the artisans, and to the army of merchants that piled up the riches to make Venice a power on the Mediterranean.

Filipinos have come in contact, not with life but with books, and their immediate ambition is to produce the things which are talked of in books. Situated 
as these Islands are, remote from any great modern civilization, there is no criterion by which the inhabitants can arrive at a correct estimate of their condition. If here and there a single Filipino educated in Europe should dazzle society with novels or plays or happy speeches, most of his countrymen would be satisfied with his vindication of Filipino capacity.

There are two things which are absolutely necessary to the future development of the Philippines, whether they remain under our flag or become independent. One is a new aristocracy to be a new type of incentive to the laborer; the other is an increase in the laborer's wants which will keep him toiling long after he has discovered the futility of the hopes which urged him in the beginning. At present, the American Government is trying to remodel a social system which consists of a land-holding aristocracy and an ignorant peasantry, the latter not exactly willing to work for a pittance, but utterly helpless to extricate themselves from the necessity of doing so. To the aristocrat the Government says, "Come and aid us to help thy brother, that he may some day rob thee of thy prerogatives" ; and to the peasant, "O thou cockfighting, fiesta-harboring son of idleness and goodnature, wake up, struggle, toil, take thy share of what lies buried in thy soil and waves upon thy mountainsides, and be as thy brother, yonder." Nor is my picture complete if I do not add that, under his breath, both peasant and aristocrat reply, "Fool! for what? That I may pick thy chestnuts out of the fire."

There is a story which illustrates the Filipino's 


\section{IMPRESSIONS OF THE PHILIPPINES}

sensitiveness to picking somebody else's chestnuts out of the fire, not inappropriate to be told here. The agent of the Kelly Road Roller Company had made an agreement with a number of Filipinos in the Maraquina Valley to take up a rice thresher and to thresh their crops for one-twelfth of the output. As this was cheaper than the usual cost of rice-threshing, they accepted the offer, but they were anxious to compare the new machine with their own system. One way of threshing rice is to have a kind of stone table like an armchair, in which the seat is a bowl for the grain which drops down as the thresher strikes the laden stalks against the stone back. On the appointed day the American appeared with his thresher, and the Filipinos were on hand with their stone table and a confident expert who was reputed the best rice-thresher in the district. The American began to feed his machine, and the Filipino made his bundles cut the air. In a few seconds the Filipino had quite a little handful of grain collected in his stone bowl, but not a grain of rice had appeared from the thresher. The workman cast supercilious glances at the machine, when suddenly a stream of rice as thick as his wrist began to pour out, and continued to pour in startling disproportion to his tiny pile. He stood it half a minute and then laid down his bundle of stalks and strode away. The onlooking landholders were at first amazed and delighted. Then suddenly a horrible thought struck them! They got out their pocket pads and pencils and began to figure. Then they held a consultation and declared that the deal was off - that for one- 
twelfth the amount of rice streaming out of the thresher, the American's profits would be highway robbery of the poor Filipino. In vain the agent pointed out to them that the one-twelfth was a ratio in which their gain would always be proportionate to his. They could see nothing except that he was going to make a large sum of money at their expense. The economy of the thresher over their own wasteful system made no impression against the fact that his commission would be a bulk sum which they were unwilling to see him gain. They could not afford to buy the machine, but they stopped the threshing then and there; and the agent learned that what is good advertising in America is not necessarily good in the Philippines.

The reader may fancy that he perceives in this chapter a direct contradiction of what I said in a preceding chapter about the Filipino aristocrat's desiring the best of everything for his country. But the Filipino is like the sinner who says with all sincerity that he desires to be saved, but who, when confronted with the necessity of giving up certain of his pleasures as the price of salvation, feels that salvation comes rather high, and begins to figure on how he can accomplish the desired result without personal inconvenience. The present land-holding aristocracy is jealous to the last degree of its prerogatives, and it has fought every attempt to equalize taxation and to make the rich bear their fair share in the national expense account. The land tax and the rentas internas, or internal revenue tax, are two governmental measures which 


\section{IMPRESSIONS OF THE PHILIPPINES}

the rich classes fought to the extreme of bitterness, and which they would revoke to-morrow if it lay in their power to do so.

An aristocracy represents a survival of the fittest not necessarily the ideally fit, but the fittest to meet the conditions under which it must prove a survivor. The conditions which Spain created here to mould Filipino character were mediæval, monarchical, and reactionary. The aristocracy is a land-holding one, untrained in the responsibilities of land-holders who grow up a legitimate part of the body politic of their country. Previous to American occupation the aristocracy was excluded from any share in the government, and the Spaniards were exceedingly jealous of any pretensions to knowledge or culture on its part. The aristocracy which could survive such conditions had to do so by indirectness and courtier-like flattery, by blandishment and deceit. The aristocrats learned to despise the poor and the weak; for the more extravagant the alms-giving, the more arrogant the secret attitude of the giver. They trusted less to their own strength than to others' weakness. They relied less on their own knowledge than on others' ignorance. Whatever solidarity the aristocracy had and has today is of a class nature rather than of a racial. In the insurrection against Spain it allied itself with its lowerclass brethren simply because Spain forced it to do so. Had the friars made concessions to the aristocracy as a class, and permitted them a voice in Filipino affairs, there would have been no insurrection against Spain, nor would the entrance of a Filipino governing 


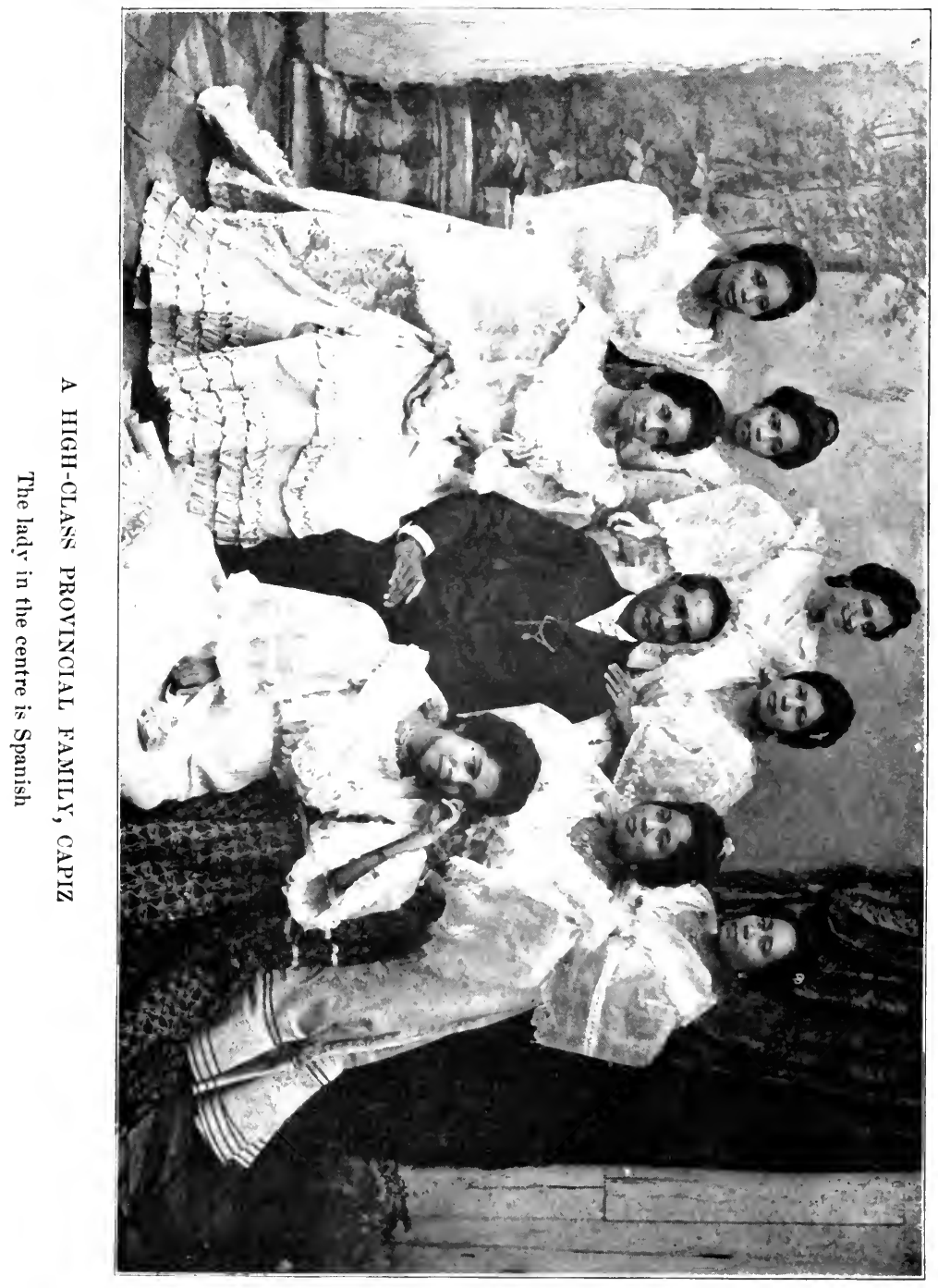



class have made large changes in the conditions of the great mass of the Filipino people.

Under a democratic Government the present aristocracy cannot retain its present place and prestige, and a portion of its eagerness for independence comes from a recognition of that fact. The American Government has practically opened the way for the creation of a new aristocracy in establishing the public schools. In the provinces the primary schools are patronized by rich and poor alike, though it has required considerable effort to make the poor people understand that their children have as much right to the enjoyment of school privileges as have the children of the rich. The secondary schools of the provinces are patronized chiefly by the middle and upper classes, and in the city of Manila the children of the really wealthy hardly ever attend the public schools. The wealthy citizens of Manila prefer to send their sons to the religious schools, and their daughters to the colegios, or sisterhood schools, of which there are many. While English is taught in all these schools, general instruction is in Spanish; the courses of study include the usual amount of catechism, expurgated history, and the question-and-answer method of "philosophy" of the old Spanish system. If the American Government remain here, a new aristocracy, the result of her public school system, is inevitable. If it should not remain here, the Spanish-reared product will continue to hold its present place. 


\section{CHAPTER TWELVE}

PROGRESS IN POLITICS AND IMPROVEMENT OF THE CURRENCY

Our First Election of a Governor - More Feeling in our

Next Election - We organize a Self-governing Society in the School- Improvement in Parliamentary Procedure - The Boys imitate the Oratory of a Real Politician - A much-mixed Currency in the Philippines - Losses to the Teachers through Fluctuations in Exchange - The Conant System brings Stability The New Copper Coins astonish the Natives.

$\mathbf{W}^{\mathrm{n}}$

$\mathrm{E}$ had been in Capiz but a short time when talk of the coming election began to occupy both Americans and Filipinos. The Governor of the province at that time held his position by appointment from Mr. Taft, but provisions had been made by the Commission for an election at a specified time, which was then at hand. In view of the fact that it was the first election ever held in the province, we Americans expected to encounter much rejoicing over the newly acquired right, and a general outbreak of gratification. It made a barely perceptible ripple. The Filipinos had not gathered momentum enough under the new system to approach an election by the well-recognized channels. There were no speeches, no public gatherings, no processions, and, so far as the mass of the population were concerned, 
no interest whatsoever. There is not universal suffrage in the Philippines. The electors for the occasion were the consejales, or town councillors, of the towns in the province. On a given day they would assemble to cast their votes.

Our appointed Governor was a candidate to succeed himself, and the only opponent of any importance was a local lawyer, named D-. D— was on very good terms with most of the Americans, who regarded him as something of an Americanista, but he was greatly hated by the prominent Filipino families in town, not only on the score of his suspected pro-American sentiment, but on account of certain meddlings of his in past time with cacique power.

A short time before the election the American community were thunderstruck on hearing that $\mathrm{D}$ had been arrested on a charge of murder. Our Supervisor - and, I believe, the Treasurer - offered to go on his bail. Then came a telegram from Judge Bates at Iloilo, denying bail. For a day or two telegrams flew back and forth, the Americans trying to secure the temporary release of the unfortunate lawyer but accomplishing nothing. $\mathrm{D}$ - was kept practically incomunicado in the local calabozo. He insisted that there was a plot on foot to destroy him, and either he was much distressed or he pretended to be so. Then came an order to take him out to a small town in the interior whence the charge came. D- declared that he should be killed on the way. The Americans finally prevailed upon an American inspector of constabulary to accompany the prisoner's escort. The rainy season 


\section{IMPRESSIONS OF THE PHILIPPINES}

was in full force, and prisoner and escort had a bad time getting out to Maayaon, the town aforementioned. Once there the charge broke down at once. It was based upon a statement made by an old woman that a spirit had appeared to her in a dream, and had accused $\mathrm{D}$ - of being the cause of its immaterial existence. The prisoner was almost immediately set at liberty. For reasons best known to himself, he found it inconvenient to return to Capiz and to renew his campaign for the governorship.

By the fortuitous circumstance of the charge against $\mathrm{D} \longrightarrow$, our Governor, who professed a smiling ignorance of all the circumstances of the case, had been relieved of his only formidable rival, and he prepared to do the honors of Capiz to the consejales. He lived in the old palace of the Spanish governors, which had since come to serve as provincial capitol and gubernatorial residence. There was plenty of room in the fine old place, and the consejales found everything to their satisfaction. They had but to step out of their bedrooms to find themselves at the polls. Our Governor was elected almost unanimously, to succeed himself for two years.

That was doing pretty well for a set of tyros at politics; but by the time the next election swung round, political feeling had awakened, there were wheels within wheels, and feeling was running explosively high. Political parties had crystallized into two bodies, known as Progresistas and Federalistas. The Progresistas were the anti-American party, pledged to every effort for immediate independence. The Federalistas were those who stood by the Taft adminis- 
tration, and talked of compromise in the present, and of independence at some distant day. Our Governor, who was again a candidate to succeed himself, was the Federalista head. The Federalistas accused the Progresistas of being "Aglipianos" - that is, schismatics from the Roman Church - and they hinted that Aglipianoism was more a political movement than it was a religious one.

Each party professed itself sceptical of the good intentions of the other. Each was certain that the other would come to the polls with firearms and bolos. I began to worry about my desks, having promised to loan twenty-five nice new oak ones of the latest American pattern for the use of the consejales in making out their votes.

The officer commanding the constabulary at that time was a huge, black-browed, black-whiskered Irishman, who, among the American men, went by the name of "Paddy" L__ Both parties ran to Captain L_-, clamoring for a military guard at the election. Captain L- pooh-poohed the notion that any serious trouble could grow out of the election, declined to consider a guard, except the two soldiers to guard the ballot box, who were more for function than for protection, and smilingly added that his trust in the Filipino sense of law and order was so great that he intended to go to the election and see it all himself.

By this time the Governor's family had removed from the government building, and a suite of apartments at the rear which had served for kitchen, diningroom, store-rooms and servants' quarters, had been 


\section{IMPRESSIONS OF THE PHILIPPINES}

cleaned up, painted, and handed over to the Provincial Intermediate School, of which I was principal. One of our school-rooms was connected by an uncurtained glass door with the great central hall of the building, which was usually given over to the Court of the First Instance, but which was, that day, a sort of anteroom to the voting precinct located in the former sala of the palace. My school-room would, therefore, command a full view of the polls. For several days I lived in dread of hearing that election day would be declared a school holiday, but no order came to that effect, and on election day I went to school with my mind bent on taking notes of all that went on, also wondering a little if in case the non-expected riot came off, I should not have to vacate a little hurriedly.

By nine o'clock the court-room was packed with electors and lobbyists, or whatever the interested outsiders may be called. Through the glass doors we could see them in groups, some laughing and chatting in ordinary social converse, others dark and gloomy, others gathered in whispering knots with fingers on lips, much mysterious nodding and shrugging of shoulders, and all the innocent evidences of conspiracy. Beyond, through double doors, the voting precinct was in full view, my twenty-five desks occupied by meditative consejales, sucking the ends of their pencils. There were the judges and the ballot boxes, symbols of progress and modernity, and there, too, as a concession to dignity which fills the Filipino with joy, were two dear little constabulary soldiers with guns about as 

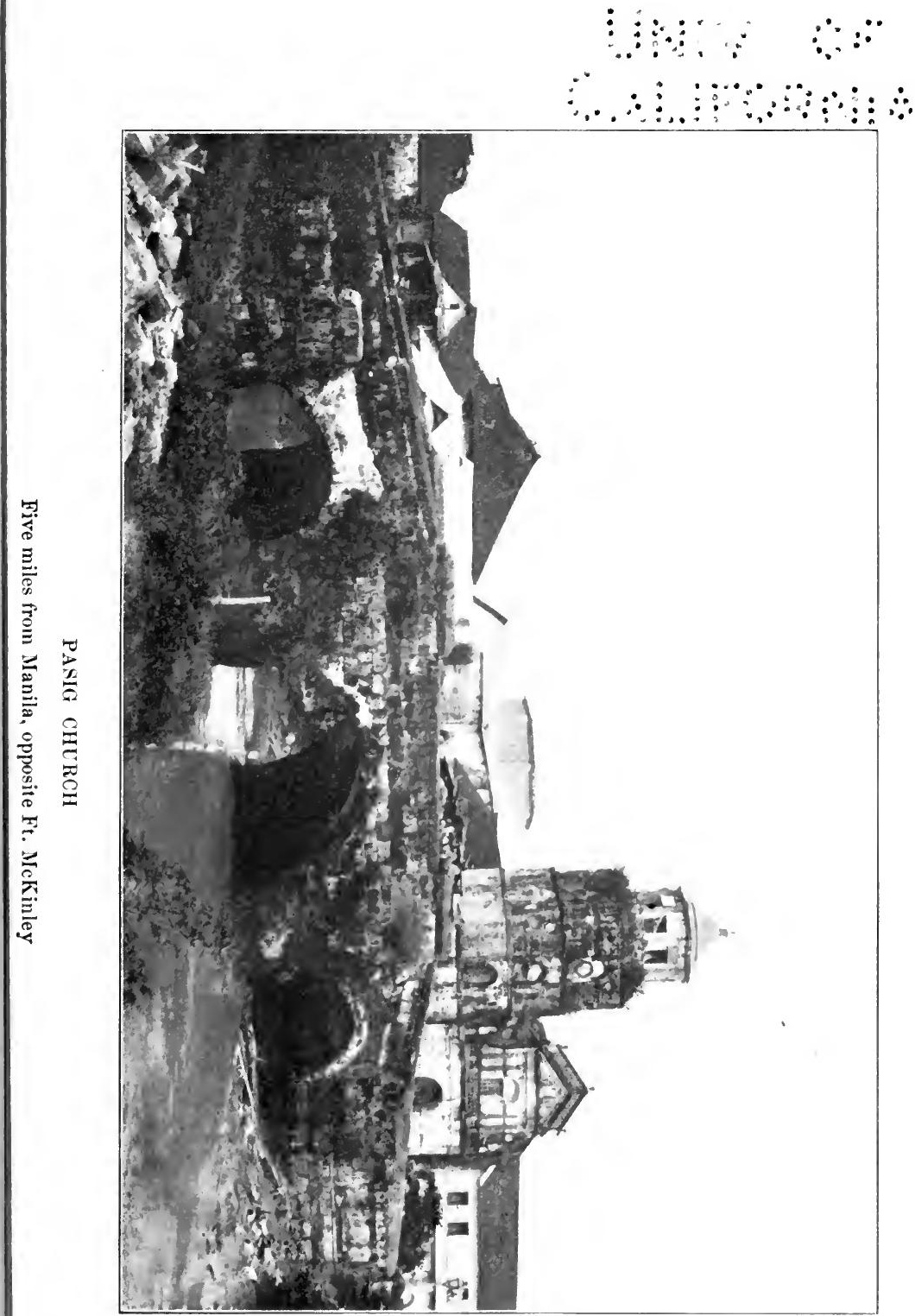

long as themselves. Their khaki suits were spick and span from the laundry, their red shoulder straps blazed, their gilt braid glittered, and their white gloves were as snowy as pipe clay could make them. Their little brown faces were stolid enough to delight the most ambitious commander. The whole was a sight to cheer the heart of rampant democracy.

In the midst of the throng in the court-room, jovial, lusty, bright of eye, loitered our easy-going chief of constabulary. His was no common girth at any time, but belted with a particularly large-sizèd and viciouslooking revolver, he seemed to be at least sixty inches around the waist. There was something casual about that revolver, and at the same time something very significant. But nothing could have been more blandly unconscious than the Captain's manner. He had what is commonly described as "a kind word and a sweet smile for everybody." There werè constabulary reserves a block away, but the Captain's appearance was an assurance that there would be no need for the reserves. He loafed about, chatting first with one group and then with another. The conspirator looks gave way to laughter and clappings on the back, but when he turned away, more than one eye followed the time-worn holster and its bulky contents.

That election went off as calmly as a county fair much more calmly, indeed, though there was a reclama afterwards, and a long struggle about it which had to be decided by the Court of First Instance. The quarrel over the election was not related, however, to the Captain's presence there. 
Apparently the Church was interested in the election, for every shovel-hatted padre in the district seemed to have come in for it. They and the provincial dignitaries from towns which had not then risen to the dignity of an American public school, wandered into the school in groups of three and sometimes of twenty. It was their first contact with coeducation, and they were highly amused at the sight of a class of boys and girls working together in the reduction of compound fractions. They were also delighted with" the choral music, especially with "The Watch on the Rhine" which the pupils sang with great enthusiasm.

Not very long after that election we began our first work with self-governing societies. The school had been long enough established to have an advanced class capable of speaking English, and our Division Superintendent suggested that I give them a little practical experience in the "machinery of politics." I assented with outward respect, and then retired to smile, for the "machinery of politics" is the last thing in which the Filipino has need of instruction from us. $\mathrm{He}$ is a born politician, and we compare to him in that respect as babes to a philosopher. But I recognized that my pupils did need the experience of a selfgoverning society, and practice in parliamentary usages, and so we organized our society from the three most advanced classes in the school.

In the beginning I organized the society, acting as temporary chairman. I called for an election by informal ballot of short-term officers to serve until a 
time of regular elections could be set. Our first ballot polled seventy-three votes, although there were only fifty-five persons in the room. I threw that out and called for a roll call vote. In due time a regular election took place, and officers for three months were elected. As the vote was open, the aristocratic element came off best, as was to be expected. The children of one prominent family, together with some of their friends, held every office. Practically the result was not bad. The officers, four out of five of whom were girls, represented considerable ability. The girls were elected chiefly out of the galanteria of certain of the boy aristocrats, who had very little conception of what a self-governing society means, but who wished to pay their fair innamoratas a compliment.

Our society was a pronounced success. The pupils took to parliamentary practice very much as they would to a new game. Visitors thronged our Friday afternoon meetings. We teachers had to put in six or eight hours every week, drilling the pupils on duty, helping to get up music, and meeting with committees. A teacher was parliamentary "coach," and sat at the side of Madame President, giving her directions in an undertone. All the teachers were elected honorary members, and one was critic. Peace reigned and Joy flapped her wings.

About this time, however, the gentlemen who were running that province engaged in the real game which we were imitating, and became involved in a quarrel which threatened to strain the relations between Americans and Filipinos to the breaking point. Gov- 


\section{IMPRESSIONS OF THE PHILIPPINES}

ernor Taft came down in person to look into the affair. There was a banquet and there were speeches. The Filipino Governor prefaced his oratorical flight by the statement that three times only in his life had he trembled. Time has clouded my memory, but I think he said the first of these was when he took his Bachelor's degree from the University of Spain; the second was when he led his fair partner to the matrimonial altar; and the third was that present occasion when he stood up before that illustrious assembly, seeking words in which to welcome the distinguished guest.

He did not look as if he were suffering from nervousness, and his words flowed with sufficient ease to indicate that he was not having much trouble in the search. Sitting at the far end of the festal board, contemplating my glass of tinto (I am unable to say whether I drank tinto because the champagne ran short or because, being feminine and educational, I was deemed unworthy of the best), I reflected somewhat cynically that if he was telling the strict truth, his childhood must have been singularly barren of the penalties which follow real childish joy, or else his was a remarkable personality.

But that is neither here nor there. The utterance wafted me a gentle amusement at the time. But from that time on, the boys of my literary society began to tremble - always twice anteriorly, and for the third time when they stood up before that intellectual and critical assemblage. Every boy for weeks to come used that worn-out preface for his remarks. The 
pupils gave no signs either of amusement or scorn. Apparently they received it seriously as an eminently becoming preface of oratory, just as they do the "Dominus vobiscum" of the mass. But one day I spoke of it in one of the classes - intentionally not in the society. When they saw our viewpoint, they shrieked with delight, and from that time on, the budding orators ceased to tremble.

At last we arrived at the point of an open session, and the event was what is described in society papers as one of the social events of the season. We had really a good programme, we transacted quite a little business in accordance with parliamentary usage: we elected the Governor, the Presidente, and several prominent citizens honorary members, and they acknowledged the compliment with appropriate remarks.

About a week after our open session I was about to retire one night, when I heard the sound of music and saw lights approaching. Transparencies were waving about in the warm air. As there was no cholera, and therefore no occasion for a San Roque procession, I hung out of the window, local fashion, to find out what it was all about. It was a newly organized parliamentary society parading. In less than a month three new societies had blossomed among the youths and old men of the town. American teachers were engaged as parliamentarians, although the societies were conducted in Spanish, not English. The societies all died a natural death in a little while; but of course, the school society being compulsory could not die, and so far as I know is still going on. Every public 
school of the secondary class has its school societies, and they must form the ideals of the new generation.

One of the most irritating features of life in those early days, and one which offered a problem rather difficult for the Government to solve, was the matter of currency. The money in use was silver, with a small paper circulation of Banco Espagnol - Filipino notes. The notes were printed on a kind of pink blotting paper which looked as if it would be easy to counterfeit. The silver was what we called at first "Mex" and later "Dhobie." There were some pieces coined especially for the Philippines, but in general "Mex" was made up of coins of Spain, Mexico, Islas Filipinas, Hong-Kong, Singapore, Canton, and Amoy - only the experts of the Government could tell where it all came from. With the public at large, any coin that looked as if it contained the fair average of silver was accepted. Every month the paymasters of the United States Army and Navy issued thousands of dollars in American silver and paper, but this disappeared in a twinkling, swallowed up by the local agents who were buying gold with which China paid her indemnity. Each incoming steamer brought loads of "Dhobie" from the Asiatic coast, but our good dollars and quarters went out of sight like falling stars.

The silver coins consisted of pesos, medio-pesos, pesetas (twenty-cent pieces), media-pesetas (ten-cent pieces), and it seems to me that I have a hazy recollection of a silver five-cent piece, though I cannot be certain. The copper coins were as mongrel as the silver. 
There were English, Dutch, Spanish, and Chinese coins from the neighboring coasts, but the greater part of the copper coins consisted of roughly pounded discs with ragged edges, which were made, they said, by the Igorrotes. The coins had no inscriptions, but went with the natives by the name of "dacolds" the native word for "big." The Americans renamed the dacolds "claquers," and used either name at pleasure. It required eighty dacolds to equal one peso, forty to a half-peso, sixteen to a peseta, eight to a media-peseta. Theoretically a peso was a hundred cents, as a peseta was twenty cents, but there was no cent with which to make change. You accepted the dacold at its value of eighty to a peso, or you transacted no business. The Filipinos also had a way of figuring a medio-peso as cuatro reales, thus giving the real a value of twelve and a half cents, though there was no coin called a real. Nevertheless, the real figured in all business transactions.

At the time we landed in Manila "Mex" stood with gold at an even ratio of two pesos "Mex" for one dollar gold. I innocently allowed a bank to transfer a gold balance on a letter of credit to an account in local currency at that ratio. A few weeks later, when I wanted to change back and carry my account in gold, they wrote me courteously but firmly that I would have to buy back that account at the ratio of 2.27 , and by the time that the transfer was finally effected, gold had jumped to 2.66. We had been told by a circular from the War Department, at the time our appointments were made, that we should be paid in gold. I 


\section{IMPRESSIONS OF THE PHILIPPINES}

drew just one cheque in U. S. currency after reaching the Islands. My second cheque was drawn in local currency at a ratio of 2.27 , but, by the time it had reached me at Capiz, gold had gone to 2.46. We had to endure the evils of a fluctuating currency for over two years. On all money sent to the States we lost heavily. So far as our daily expenses were concerned we in the provinces had very little inconvenience to suffer on account of "Mex"; but in Manila all merchants fixed their prices in gold and took occasion to put them up mercilessly. I remember trying to buy some Japanese matting which could have been bought for twenty-five cents a yard in the States, but which was priced at seventy-five cents in Manila. The merchant wanted me to pay him in "Mex" at a ratio of 2.66 , or at the rate of two pesos a yard for matting which he bought in Japan at probably less than twenty sen a yard.

There was a tremendous protest against the fluctuating currency and the extortion which grew out of it, and we were all relieved when we learned that Congress had adopted the so-called "Conant" system of currency for the Islands. Mr. Conant was the expert who investigated conditions for the Government and devised the system.

The Conant system followed the old Spanish values for coins, the new coins being pesos, medio-pesos, pesetas, media-pesetas, nickels, and copper cents. There was also a copper half-cent, but neither Congress nor Mr. Conant read the Filipino aright. In two years we had taught him to sniff at any value less than a cent. 


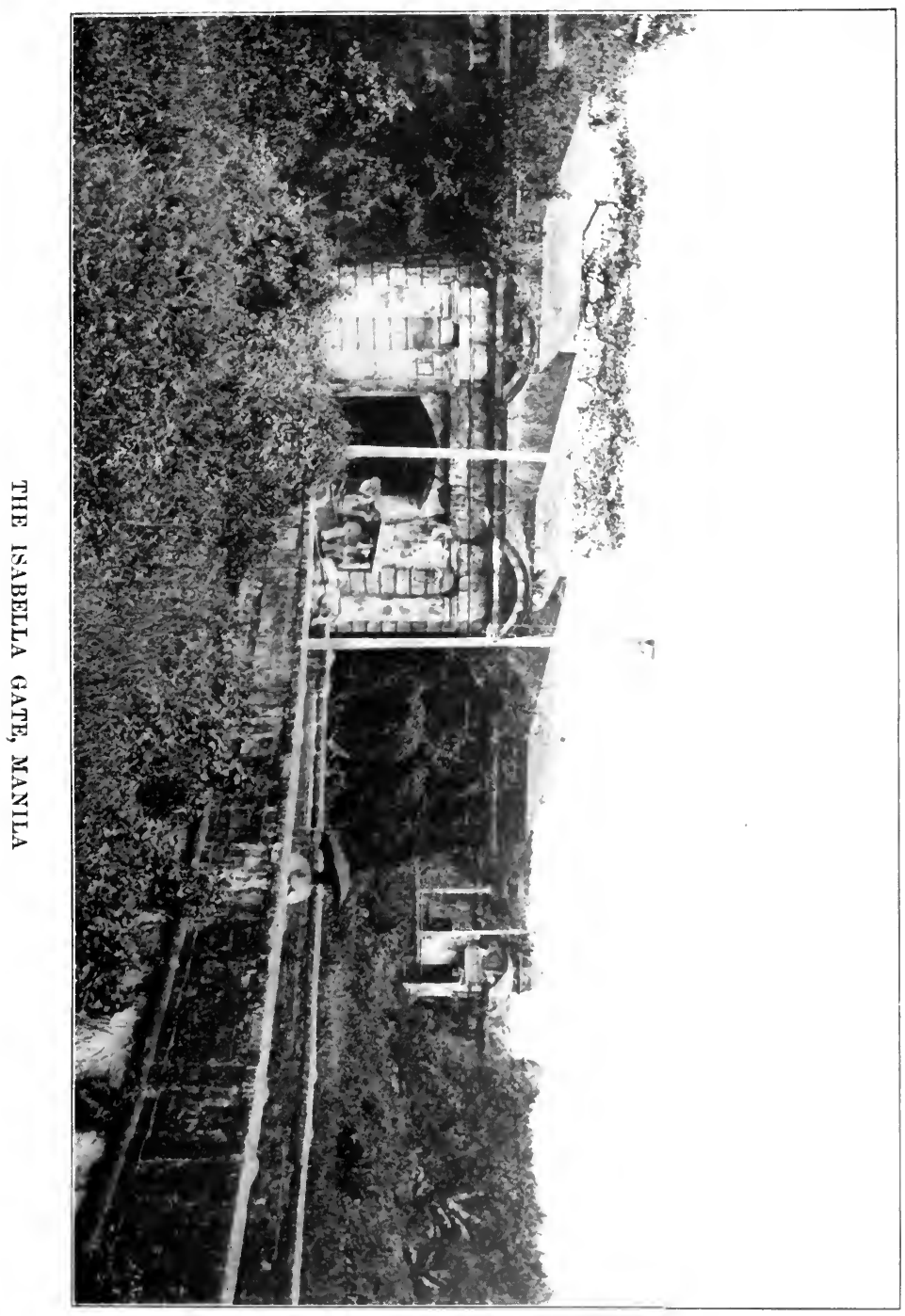



The new system is held at a ratio of two to one by the Government's redeeming it in the Philippine treasury at a ratio of two pesos Conant to one dollar U. S. The importation of "Mex" is no longer permitted, and we rejoice in a stable currency once more.

We provincials followed the newspaper talk about the new system with no small interest. When our treasurer informed us that he had received a consignment of the new currency, and that our next salary cheques would be paid in "Conant," we were delighted. My cheque, by some accident, got in ahead of those of the other employees, and was the first presented for payment.

The beautifully made, bright new silver coins had an engaging appearance after the tarnished mongrel coins to which we were accustomed. When the Treasurer had counted out all my hard-earned money except ten pesos, he produced two bags of pennies, and announced that I should have to take that sum in small coin in order to get the pennies into circulation. They were of beautiful workmanship, yellow as gold and heavy as lead. I called in the aid of a small boy to help me lug home my three bags of coin.

I had been at home only a few minutes when in came the regular vender of eggs and chickens, who called at my house three times a week. He squatted on the floor and I sat in front of him in a rocking-chair, watching my little maid drop the eggs into water to test their freshness. After we had chaffered the usual time and had come to an agreement, I went into my room and brought out the bags of new coin. I had 


\section{IMPRESSIONS OF THE PHILIPPINES}

bought about seventy-five cents worth from him, and I first gave him three of the new silver pesetas, which he admired greatly. There were still fifteen cents due him; and when I reached my hand into the penny bag and hauled out a handful of gleaming copper, the maid said, "Jesus!" under her breath, and the man, "Dios mio!" He received his fifteen centavos with an attempt to conceal his satisfaction. The maid requested permission to look inside the bag, and when she had done so merely grinned up at me with a look that said, "My! You're rich, are n't you?"

It was Saturday morning, and I went on busying myself about things at home. Pretty soon there came a deprecatory cough from the stairway - the local method of announcing a visitor. Outside of Manila knocking or ringing does not seem to appeal to the Filipinos. In the provinces the educated classes come to the foot of the stairway and call "Permiso!" and the lower-class people come to the head of the stairway and cough to attact attention. My chicken man had returned. Was it possible that he had heard aright when he had understood the Señora to say that twenty of the new gold pieces went to one peseta? The Señora explained that he had made no mistake. Then, said the old rascal, with bows and smirks, since the lady had so many of them - bags full of them - had he not seen with his own eyes? - would she have the kindness to take back those gleaming new pesetas, which were indeed beautiful, and give him gold in their stead? The lady assured him that the new money was the same metal used in the old "dacold" and that in time 
it would become as dark and ugly, but his Filipino habit of relying on his own eyes was in full command of him. The man thought that I had got hold of gold without knowing it, and supposed that he was getting the best of me. I changed one peseta into coppers for him, and had difficulty in getting him to leave the house. Ten minutes after he had left, a woman came in to sell me some more chickens. I told her that I had just bought, but she put such a price on chickens as had never before come under my ken. Ten cents was acceptable for a full-grown laying hen, the ordinary value of which was forty or fifty cents. I suspected her of having had some information from the old man, and, in order to find out, I gave her the price of the five chickens, which I agreed to take, in the old "Mex" media-pesetas. Then there was an explosion. She reached for her precious chickens and broke that bargain then and there. Her chickens would sell for ten cents gold, but for no media-peseta. I asked her how she knew I had gold, and she said that did not matter - I had some "diutang-a-dacolds" (little dacolds), and she was willing to sell hens for ten "diutanga-dacolds" gold, but not for media-pesetas. So I counted her out fifty new coppers and we both rejoiced in our bargain. I told her that the media-peseta was worth ten dacolds, but she wanted the bright new money.

For the next two hours I was persecuted with trucksellers. Ordinarily the fishermen were unwilling to stop and sell in the streets or in private houses, preferring to do all their business in the market, but that 
morning, I could have had the pick of half the catch. Finally came a woman who had had a straight tale from the first woman. Woman number two had nothing to sell, but, after a minute, she pulled out a jagged old media-peseta and said that she had heard that I said that a media-peseta was worth ten of the new gold pieces. If I was as good as my word, why not change her media-peseta for gold? I said that I would do it if she would give me the new media-peseta, but that I could not do it for the old. When she wanted to know where she could get a new media-peseta, and I told her the Treasurer would redeem old silver at the government ratio, she went off to get a new mediapeseta, but it was plain that she distrusted me. The people flocked to my house all day trying to get me to buy something and to pay them in the new coins.

It was remarkable how easily and quickly one circulating medium disappeared and another took its place. At first there was some trouble about getting the poor people to recognize the copper on a basis of a hundred to a peso. They were willing enough to receive change on that basis, but, in giving it, tried to treat the new centavo as a dacold, eighty to the peso. I had to have one Chinese baker arrested for, persistently giving short change to my muchacha, and the Treasurer had a long line of delinquents before him each morning admonishing them that they could not play tricks with Uncle Sam's legal tender. But on the whole the change went off quickly and without much friction.

This morning I asked my maid, an elderly woman, 
if she remembered the old money. we had four years ago. She struck her forehead with her hand, and thought a long time. Finally her face lit up. She remembered those Iggorote dacolds and a silver fivecent piece - "muy, muy chiquitin" (very, very small). She said that the Tagalogs called the dacolds "Christinas" after the mother of the Queen-mother. But the difference between a stable and a fluctuating medium meant nothing to her, and probably many of her countrymen have almost forgotten that there was ever any other than Conant in the land. 


\section{CHAPTER THIRTEEN}

\section{TYPHOONS AND EARTHQUAKES}

How Typhoons assert themselves - Our First Typhoon Six Weeks' Mail brought by the General Blanco-Her NARrow Escape from Wreck - A Weird JoUrney on a still Smaller Steamer - Another Typhoon - Rescue of Captain B- - Havoc wrovght by the Typhoon.

T $\mathrm{N}$ the month of November two more American women teachers arrived at Capiz, one of whom 1 joined me, and our society was still more increased by two army officers' wives, and the wives of the provincial Treasurer and the Supervisor. This made nine women in all, and we began to give dinners and card parties, and assume quite metropolitan airs.

Miss C - and I, from our central positions on the plaza, saw and heard most of what was going on, and we heartily concurred in the gossip of the day that there was always something doing in Capiz. About the middle of the month there was a lively earthquake that shook up our old house most viciously; and just before Thanksgiving we met our first typhoon.

Typhoons have various ways of asserting themselves, but there is one predominating form of which this particular typhoon happens to be an example. The beginning of all things is usually a casual remark dropped by a caller that the first typhoon signal is up. Then the 
weather thickens, and a fine drizzling rain sets in. It stops by and by, and you have no sort of opinion of typhoons. Then the rain begins again with a steady downpour, which makes you wonder if there will be any left for next year. Again it stops, almost leads you to think it intends to clear. Then a little vagrant sigh of wind wafts back the deluge. A few minutes later nature sighs again with more tears. Each gust is stronger than the one before it, and at the end of eight or ten hours the blasts are terrific, and the rain is driven like spikes before them. It may keep this up twelve hours or fifty-six. It may increase to an absolute hurricane, levelling all before it with great loss of life, or it may content itself with an exhibition of what it could do if it really desired.

At the end of the first day of our typhoon I went to bed wondering how long the ant-eaten supports of our house could hold out against the violent wrenchings and shakings it was getting. I had poor rest, for the howling of the wind, the noise of boards torn loose, and the clatter of wrenched galvanized iron roofing made sleep almost impossible. When I went out into the kitchen next morning, my heart sank into my boots. The nipa roof had been torn away piece by piece. The whole place was soaked, the stove was rusted, and rivulets were running outside and inside of the pipe. Romoldo clucked his glee in this devastation, and opined that the outlook for breakfast was poor. It was certainly no poorer than breakfast when it came.

I dressed myself for the weather and went to school in a mackintosh and rubber boots. The costume seemed 
to afford no small excitement to the Filipinos who beheld. They had hitherto considered mackintoshes and rubber boots as the exclusive property of men. Had I appeared in a pair of pantaloons, I should not have created more sensation. Nobody came to school, of course, but I had to go through the form of reporting there twice anyway. We lunched on gingersnaps and water, and' had a dinner composed chiefly of tinned things.

After dinner, to our immense surprise, we had callers in spite of the storm. Lieutenant and Mrs. C_- came over to ask us to Thanksgiving dinner, and a couple of men from the officers' mess dropped in. One of these, Captain R-, was in command of the launch kept at Capiz by the military Government. She was about sixty feet long, and having been built at Shanghai, rejoiced in a Chinese name - the Yuen Hung. But as something was the matter with her engines, which coughed and wheezed most disgracefully, the flippant Americans had rechristened her the One Lung, much to the chagrin of her skipper.

A barkentine, loaded with molave timber and carrying native passengers, had been driven ashore at the port that day, and the One Lung had gone to the rescue and taken off the passengers. Fortunately the little craft did not have to brave the full force of the sea, as the arms of the bay broke the fury. But even in the bay Captain $\mathrm{R}$ - said the waves were frightful, and he thanked his stars that they had gotten back alive.

While we were still talking of the storm, there came a 
shout from the tribunal next door, and the noise and rattle of the four-horse escort wagon starting down to Libas. That could mean but one thing - States mail, the which, as we had seen none of it for six weeks, was particularly welcome. But we wondered what boat had come in in such a storm, and, the unexpected always happening, were not wholly unprepared to learn that that disreputable old tub the General Blanco had made harbor safe and sound. It took till nearly midnight to get the mail up and distributed, but we stayed up for it. There were actually eight sacks of mail for our little colony, and we went over to the tribunal and watched the mail sacks opened, and seized on our share with avidity, while we alternately blessed and despised the skipper of the Blanco for getting caught out in the tempest.

This was not the last feat the Blanco was destined to achieve during my stay in Capiz. She had a habit of dropping into port in weather that it seemed no boat could live in. Once she came in about two P. M. in a tremendous sea, bringing a single American passenger - a girl of twenty-one, a Baptist missionary. As the Blanco had no cabins, the captain was forced to lock his native passengers in the engine room, where no doubt they contributed much to the enjoyment of the engineer and his aids. He had the deck chair of this girl carried up on his bridge and lashed, and she was lashed to the chair. There they two rode out the storm. The captain said that from eleven o'clock till two, when he made the shelter of Batan Bay, he expected his boat to be swamped any instant, and he expressed his unquali- 
fied admiration for the way in which this girl faced her possible doom. He concluded with a favorite Filipino ejaculation, "Abao las Americanas," which in this case may be freely translated as "What women the Americans are!"

The Blanco is still skipping defiantly over the high seas between Iloilo and Capiz, though after all her hairbreadth escapes she came near ending herself in a typical way. She started out one night from Capiz for Iloilo, a heavenly calm night, bright moonlight, and a sea smooth as a floor. Two or three miles from the port, a large island called Olatayan lies off the coast a single mountain rising out of the sea. Everybody on the Blanco, including the watch and the steersman, thought it a good night for sleep, and left the General to steer her own course. The General made straight for Olatayan, and ran her nose up on the beach. She stayed there two weeks, and was beaten up by bad weather, and assistance had to be sent to get her off. Then she had to be pretty well rebuilt, and repainted. At the time of all these happenings I was in Iloilo, whither I had gone for treatment of an abscess of the middle ear, and as I depended on the Blanco for getting back, felt personally injured by her antics. I went several times to the office of her agents, one of the big English trading firms, to inquire how the wreck was getting along, and what the prospect was for a return to Capiz before Christmas. The man at the desk did not look characteristically English, and on my first appearance I addressed him tentatively in Spanish. He answered in that language, and we continued to use it. On one of 
the later visits this gentleman was not visible, but in his place a red-headed, freckled youth, with the map of Scotland outlined on his rugged countenance, presided over the collection of inkstands and ledgers. Naturally, I accosted him in English, whereupon the shape of my former interlocutor rose up from behind a screen and remarked, "By Jove, I thought you were Spanish, don't you know? and have been talking to you all this time in Spanish. What a sell!"

Failing the Blanco, I took passage for Capiz on the Fritz, a craft one or two degrees smaller and rustier than the old General. Of all the weird experiences I ever had, that twenty-four hours was the weirdest. They cleared out a sort of pantry or lazaretto just back of the deck engine-house for me to use as a stateroom, and I slept on the pantry shelf. Some kind of steam pipes must have passed under it, for it grew so hot that several times I had to vacate and get down on the floor. Then we met a little wind as we rounded the north coast, and I was sick. A family of Filipino aristocrats came on board at Estancia, and the ladies elected to share my retreat. They had several servants and one or two babies and other necessaries of life, and they left me only a corner of the pantry shelf, against which I propped my weary and seasick frame. We made Capiz just at dusk, and never was a wanderer more eager to see home. There on the bank were two of my friends, who said they were invited out to dinner and were to bring me if I arrived in time. So we went to that cheery American home with its spotless linen, its silver and china. For six weeks I had been living on Spanish 


\section{IMPRESSIONS OF THE PHILIPPINES}

"chow," and the contrast made me serenely happy. It was almost worth enduring - the six weeks of chow and the Fritz, I mean - to enjoy the change.

But to return to typhoons. We had several more that year, and I began to feel that typhoons were terribly exaggerated in books. But in 1903 we had an object lesson that I do not care to repeat. We went through all the usual preliminaries of typhoon signals, drizzle and gust. It was, I believe, the tenth of June. I stayed up late that night, working, and noticed that the gusts were increasing. Just at midnight I laid down my pen and started to go to bed, when there came a blast that shook the house like an earthquake and made me decide to wait a while. For the next three hours the storm raged in a very orgy of gladness. It slapped over nipa shacks with a single roar. It ripped up iron roofing and sent it hurtling about the air. The nipa of my roof was torn off bit by bit, and the rain came in in torrents. I used my mackintosh to cover up the books, and put a heavy woollen blanket over the piano. Then I held an umbrella over the lamp to keep the rain from breaking the chimney, and sat huddling my pet monkey, which was crazed with fear. The houses on either side were taller than mine, and for this little hollow it seemed as if all the iron roofing of the town had steered a direct course. The pieces came down, borne by the shrieking wind, and landed with rattle and bang. My house swayed at every gust. It seemed that the crossbeams in the roof moved at least a foot each way. The little lanterns that burn in front of the houses were blown out by the wind, and when I peered out there 


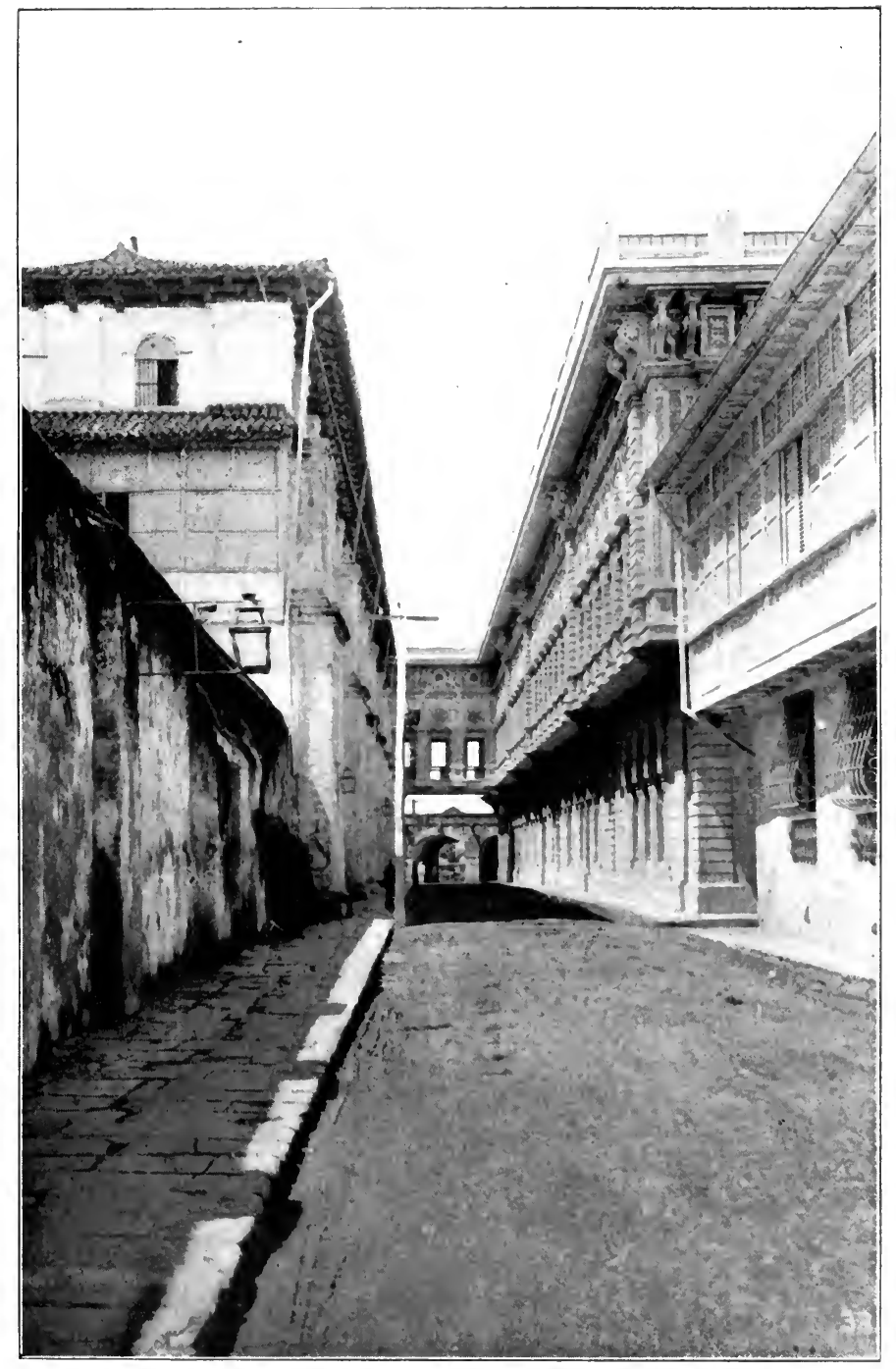

CALLE REAL, MANILA 

was nothing but the inky darkness, the howling of the wind, the thrashing of the cocoanut trees, and the thud of falling nuts. From my side window I could see the native family next door to me all on their knees in front of an image of the Virgin, and once, in a lull, caught the sound of their prayers.

The storm reached its greatest violence by half past one and subsided by about three, at which time I went to bed and slept till morning. In spite of my fear I could not help laughing at my two Filipino girl servants. They slept undisturbed through the earlier gusts, but when the roof went and the water came in, they awoke - disgusted. The oldest one said, "Mucho aguacero" (a heavy shower) and cast about for a dry spot. She did n't find any at first, but she finally concluded that the corner where my bed stood was highest; lifting the valence, they disappeared.

Next morning Capiz presented a pitiful sight. Many of the great almond trees on the plaza were uprooted and the others dismembered. The little nipa houses were flat on the ground or drunkenly sprawling at every slant and angle. Even the best houses had suffered. The constabulary cuartel was absolutely wrecked. The Supervisor's kitchen was gone, and his wife mourned for her dishes, which were scattered up and down the length of the street. The home of the scout officer was ruined. He and his wife had taken shelter under a stone wall, and been drenched for three or four hours. The young mangoes had been strewn on the ground, and there was no hope of that crop. Many of the cocoanut trees were broken off, and where this was not the 
case, the nuts had been whipped off. The banana trees were entirely destroyed. Altogether it was a sorry sight, and we all got out and walked about and viewed the ruins, just as we do for a cyclone at home.

The storm had an aftermath in the rescue of an Englishman, Captain B-, a pearl fisher. He was anchored under the lee of a small island in the sea between Panay and Masbate. He was in a small lorcha, or sailing vessel, with no barometer, his glass having been left on a lorcha of larger tonnage, which was at another point. The heavy wind caught them without warning almost, and its impact soon pressed the lorcha over. Captain B- found himself struggling in the water - able to swim, but drowning, as he expressed it, with the spindrift which was hurtling into his face. He kept one arm going, and partially protected his face with the other. Then in the inky dark he touched a human body. It was the leg of one of his crew, four of whom were clinging to one of the lorcha's boats. It kept turning over and over, and they had to go with it each time. Captain Bhung to the prow, so his circuit was not so wide as that of the others, but his body - arms, legs, and chest was literally ploughed by the rough usage. Once he let go and lost the prow as it came up, and the fright of this was enough to strengthen his hold. They were in the water clinging to this all the rest of the night, the next day, and the next night. One man died of exhaustion, and one went mad and let go. On the second morning they succeeded in bailing it out by means of an undershirt, which Captain B- had been wear- 
ing, and which, though torn to ribbons across the front, was whole in the back. They remained in the boat all day, beaten on by the tropical sun, having been thirty hours in the water without food or drink. Captain B — said they were all a little mad. They saw the Sam Shui - the boat of the commanding officer of the Visayas - in the distance, but were too low to be sighted by her. They wore their finger ends down, tearing a plank off the side to use for an oar. Meanwhile the current carried them down closer to the Panay coast, and on the third day they were close enough to fall in with one of the big fishing paraos. This carried them into Panay, a town five or six miles east of Capiz. Captain B- had just strength to write a line or two and sign his name. This was brought down to $\mathrm{Capiz}$, and the constabulary officer on duty there went out immediately with a launch and brought him in. He was in the military hospital a long time. His attending physician said that between salt water and sun he had been literally flayed, and the flesh torn into ribbons and gouged by the impact of the boat.

The storm did frightful havoc all through the Visayas, and many lives were lost and vessels wrecked. The Blanco as usual made harbor all right, but another little Capiz boat, the Josefina, went ashore, and her captain and several others were lost. The adventurous One Lung was at Iloilo, and it was reported that she started out of the river without consulting her pilot, creating thereby general consternation among her sister craft. 
We accustomed ourselves at last to typhoons and earthquakes, and, on the whole, decided that they were less fearful than tornadoes at home. Meanwhile we rather luxuriated in the sensations of romance inspired by living in a town surrounded by a hostile population and protected by soldiery. It was very, very new, and we made the best of it. 


\section{CHAPTER FOURTEEN}

WAR ALARMS AND THE SUFFERING POOR

A Surprise Party of Bolo-Men - Forty Insurrectos arrive in our Neighborhood - Anecdotes of Encounters with Insurgents - Anxiety because of Treachery of the Natives - A False Alarm - Five Hundred Starving Persons - Great Lack of Institutions for the Poor A Smallpox Patient in the School Building-The Newspaper a Creator of Hysteria.

S I said before, Capiz had never been a warlike
province, and there had been comparatively
little resistance to the American occupation. Antiqua province to the west of us had fought stubbornly and was still infested by ladrones, or guerilla troops. One engagement took place at Ibajay, a town on the north coast close to the western border of Capiz, quite worthy of description.

There was a small American garrison at Ibajay about seventy-five or a hundred - and the Filipinos planned to surprise and massacre them just at daybreak when the reveille was sounded. But the bugler was an astute youth, with an observing mind, and as he made his morning promenade, it seemed to him that there were far too many ladies squatting about on the plaza. So he got as close to quarters as he could, and instead of blowing reveille, blew the call to arms with all 
his soul, and then ran for his life. The American troops swarmed out in their underdrawers and cartridge belts, and that surprise party turned right about face. The squatting women on the plaza, who were bolomen in disguise, left for the hills with the yelling undergarmented in pursuit. A Filipino girl who saw it all described the affair to me, and said, "Abao," as she recalled the shouts of enjoyment with which the Americans returned after the fray. They seemed to regard the episode as planned to relieve the monotony of life in quarters and to give them a hearty breakfast appetite.

I had been little more than a month in Capiz when the rumor went abroad that a parao with forty insurrectos from Samar had landed at Panay, just east of us, and the occupants had scattered themselves out between Panay and Pontevedra. Pontevedra was supposed to be an insurrecto town, thirsting for American gore.

As we at Capiz were protected by a company of the Sixth Infantry and one of the Tenth Cavalry, and the Islands were theoretically at peace, we were not very much alarmed by this. But it gave us something to talk about, and we enjoyed it just as we do telling ghost stories on winter nights, when the fire is low, and there is plenty of company in case the ghosts materialize. Shortly after, however, came the shocking details of the affair at Balangiga, and we - I speak of the feminine portion of our colony - did not feel so secure by any means. The Supervisor's wife insisted upon having a guard at her house, and when any 
two American women got together they discussed what they would do in case of a sudden alarm.

I am certain that there is no braver soldiery in all the world than ours. But I am equally certain that when war is a man's profession, on which all his chances of honor, pay, and promotion hinge directly or indirectly, the wish in his mind is father to the thought, and unconsciously he scents danger because he wants danger. Of an officer it may be said, as of Thisbe's lion, that his trade is blood, and "a lion among ladies is a most dreadful thing." But nothing pleased me more than to hear the officers tell tales of the old campaign and speculate on the possibilities of a new one.

Our Supervisor had been a captain of volunteers in a Minnesota regiment. He was a thoroughly interesting talker, and an inimitable story-teller, a man who did not lose his sense of humor when the joke turned on himself. I heard him tell one or two stories well worth repeating.

Our valorous Supervisor was stationed in Antique province, while in Capiz was a detachment of the regular army. And in full sight of both on the top of a precipice, an insurrecto flag flaunted its impertinent message.

The Supervisor said he waited a decent length of time to give the regulars a chance to pull down the flag, as it lay in their province, but when they failed to act, he went out, full of hope and good United States commissary valor, to destroy the insurrecto stronghold and to give an object lesson in guerilla warfare to the regulars. His men hacked and hewed their way through the jungle and cogon grass, with never a shot 


\section{IMPRESSIONS OF THE PHILIPPINES}

from the insurrectos. Then at the last they came to a clear slope, and when they were about half-way up this, the insurrectos opened fire, not only with rifles but with great boulders. The Supervisor said it took them over two hours to get up, and they went down in less than twenty minutes. One little Dutch private was in so much of a hurry that he punched him (the officer) in the back with a gun butt and said, "Hurry up! get out of the way." Most of the shots flew high, however. The flag came down later, but it required four hundred men and a battery of artillery to bring it down.

On another occasion the Supervisor, his wife, a constabulary lieutenant, and I were out on the playa (beach) when we came to a little hollow almost hidden by grass, so that I stumbled in crossing it. This started the two men into retrospect of a day's fight over on the beach of the west coast. The insurrectos at last took to flight, and the Supervisor started after one whom he had noticed, on account of the beautiful kris, or fluted bolo, which he carried. As they ran, the Supervisor stumbled over such a grass-hidden hollow, and without his perceiving it, his revolver flew out of its holster. He kept on gaining slightly on his quarry, who glanced apprehensively over his shoulder now and then, expecting to see the big Colt come out. At last, when he thought the range was good, the officer reached for his revolver. He described the sort of desperate grin with which the Filipino glanced back expecting the end, and the rapid change to satisfaction and triumphant ferocity as pursuer and pursued realized what had 
happened. Then the race changed. It was the Supervisor who panted wearily back toward his scattered fellows, and it was the Filipino with a kris to whose muscles hope of victory lent fresh energy. Fortunately, this young constabulary lieutenant, who had been a non-commissioned officer of volunteers, saw what was going on, and picked off the Filipino with a long range shot from his rifle. The kris was secured, and its beautiful blade and tortoise-shell scabbard, inlaid with silver, went as a present to Mrs. Wright when she visited the province.

Somewhere in his "Rulers of the South" Marion Crawford speaks of the wonderful rapidity with which news flies among the native population in warfare, and he cites as an illustration that "when Sir Louis Cavagnari was murdered in Cabul, in 1879, the news was told in the bazaar at Allahabad before the English authorities received it by telegraph, which then covered more than half the whole distance between the two places." This same condition beset the American officers in the Philippines. Secretly as they might act, they found the news of their movements always in advance of them, and the crafty native hard to surprise.

Among the leaders in Panay a certain Quentin Salas who operated both in Antique and Iloilo provinces was noted for his daring and cruelty. The American troops spent much time in pursuit of him, and among others the doughty Captain of volunteers. The Captain said that Salas made his headquarters in a certain pueblo, and often word was brought that the insurrecto would be found there on a certain day. 


\section{IMPRESSIONS OF THE PHILIPPINES}

The Captain tried all devices, forced marches, and feints on other pueblos, but to no purpose. He always arrived to find his quarry gone, but breakfast waiting for him (the American) at the convente, or priest's house. The table was laid for just the right number of persons, and the priest was always affable and amused. The Captain grew desperate. He gave out false marching orders, and tried all the tricks he knew of. Finally, he let it be known that he intended to march on Salas's pueblo the next morning, and he did so, and actually arrived unexpectedly, or at least so nearly so that breakfast was not ready. The Filipinos had assumed that his announcement cloaked some other invention, and had expected him to branch off at the eleventh hour.

The Captain searched the town from garret to cellar, but no Quentin Salas. He unearthed, however, the usual score of paupers and invalids. One of these was a man humped up with rheumatism, as only a Filipino decrepit can be. The Americans finally departed, leaving this ruin staring after them from the window of a nipa shack. Months afterward, when peace had been declared, the officer heard his name called in the government building at Iloilo, and saw a keen-eyed Filipino holding out his hand. The Filipino introduced himself as Quentin Salas, and owned that he possessed a slight advantage in having viewed the officer in propria persona, while he, Salas, was in disguise. He confessed that the American had caught him napping on that day, and that he had been forced to assume hurriedly the garb and mien of an aged 


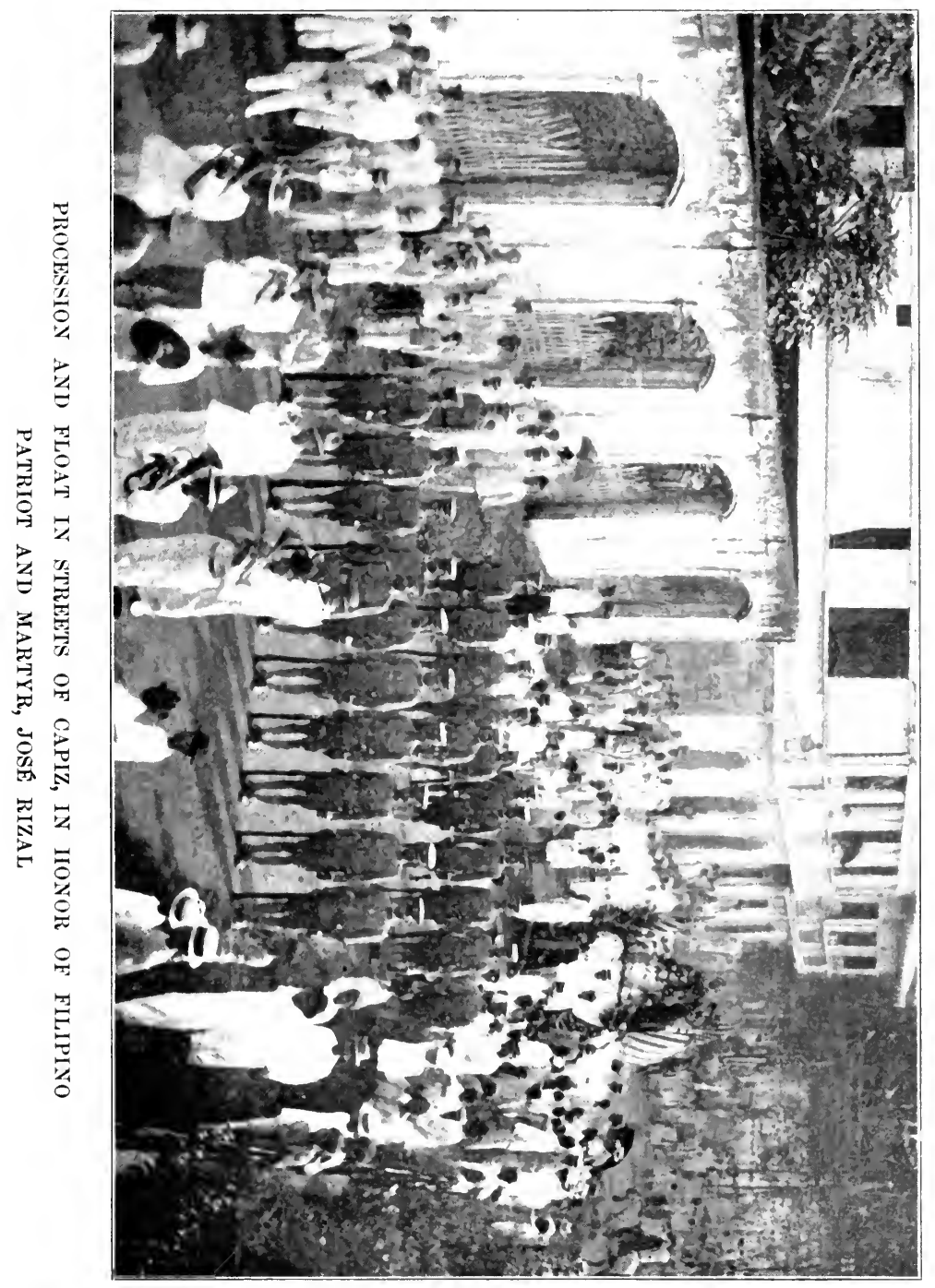



pauper. The American owned himself outwitted, and shakes his head to this day to think how near he came to victory.

We lived in a maze of war talk all that autumn. I doubt not that, to the officer commanding, much that was mere excitement to us was deadly reality and anxiety, for although peace was declared, the treachery of the natives had been demonstrated at Balangiga, and there was no certainty that the affair would not be repeated elsewhere. The American people have little conception of the burdens laid upon the army. These were to hold a people in subjection while denying that they were in subjection; to assume the belief of peace and yet momentarily to expect war; to rule without the semblance of rule; to accomplish when all the recognized tools of accomplishment were removed; to be feared and yet to be ready to bear cheerfully all blame if that fear expressed itself in complaint. I cannot but feel that the army had much to bear in those early days, and bore it well.

One little incident will serve to illustrate how lightly and yet how seriously the circumstances of life were viewed at that time. The open sea beach, or playa, two miles north of the town, was the favorite afternoon drive, and one day Miss C- who lived with me, was invited by the wife of Dr. D- to share her victoria. They left for the playa about half-past four, the Doctor accompanying them on his bicycle. He never permitted his wife to leave the borders of the town unaccompanied.

Mrș. D- was in poor health and found long drives 
unendurable, so when seven o'clock came and Miss C- had not returned, I concluded that she was going to dine at Dr. D-'s. However, before sitting down without her, I sent Romoldo up to the Doctor's to inquire if she was there. He came back saying that the $\mathrm{D}-\mathrm{s}$ had not returned, and that their servants were quite upset, as such a thing had never happened before. I waited till eight and sent Romoldo again for news. Again he brought back word that the D-S had not appeared. I thereupon went over to Lieutenant C_-'s house, who instantly picked up his hat and left to talk the matter over with the officer of the day. Thence it was reported to Captain M-, who ordered out searching parties for each of the three main roads leading out of Capiz. Just as the men were ready to start, the victoria and bicycle appeared. Our friends had stopped at a Filipino house where a saint's day celebration was in full swing, and had found it impossible to leave. The Filipino hosts had brought up ice all the way from Iloilo to make ice-cream, but as they were not adepts, it did n't freeze properly, and they would hear of no guest leaving until the icecream had been served. Miss C- said they were worried and tried to get away, but I declined to believe her. Ice-cream, I insisted, might excuse four times the delay, and I flatly refused to be convinced that they had intended to turn their backs on it after a compulsory fast of seven months.

The troops bundled themselves back to quarters, and it all ended in a laugh. Only the commanding officer leaned out of his window to chuckle at me. 
"Well, did you get your chicken?" and I went home and vowed that Miss C- should perish four times over before I would stir up an excitement about her again.

If we lived in a slightly hysterical state as concerns the possibilities of a war and bloodshed, we soon learned to be phlegmatic enough about disease and pestilence. Nearly five hundred starving people had gathered in Capiz, and their emaciated bodies and cavernous eyes mocked all talk of the brotherhood of man. This condition did not represent the normal one of the whole province, but rather these people represented the aggregate of starvation. Of course, following the war, there was a short crop and no little distress. But a certain Capiz politician with his eyes on the future caused word to be sent out through the province that if the needy would come into Capiz he would see that they were fed. Of course he did no such thing. They came and starved to death; but meanwhile the report of his generosity was spread abroad, and nobody took any pains to tell the story of how the miserable wretches had been cheated. So the politician profited and the poor died.

No one whose life has been passed in American rural prosperity can wholly realize one's helplessness in the face of these conditions. Capiz was a town of twentyfive thousand people rejoicing in many commodious and luxurious homes and a fine old church. It would seem a small affair to tide over the distress of so small a number as five hundred starving. But the greatest obstacle was the fact that they were not temporarily 


\section{IMPRESSIONS OF THE PHILIPPINES}

starving. They represented a portion of the inhabitants who either from voluntary or involuntary helplessness would always need assistance, and the people of the town did not see a clear way of assuming the burden.

I confess in my unsophistication I went out among them consuming with fine altruistic zeal. A woman with a starving child in her arms begged of me in the plaza. Instantly my purse was out, and instantly I was mobbed by the howling, filthy crowd. My purse was almost torn out of my hand, my hat was knocked over my eyes, and a hundred eager claws tugged and pulled at my garments. I had fairly to fight my way out of the mob, and learned to bestow no more alms in public. Then I took to throwing pennies out of the window, and found as a consequence that there was no rest day or night from the wailing and howling in the street. Little by little the fountain of my philanthropy dried up, and I contented myself with giving what I could to the Church to be bestowed in regular channels.

At that time there was not a single hospital (American military hospital excepted) in the Philippine Islands outside of the city of Manila, and with the exception of one or two missionary establishments, no poorhouses, no orphan asylums, - in short, no properly organized eleemosynary institutions conducted by the State. The result was one at which we Americans were first appalled, then indignant, then, through sheer helplessness, indifferent. We simply became hardened to sights and sounds which in our own land 
would stir up a blaze of excitement and bring forth wagon-loads of provisions.

Between the two stone schoolhouses at Capiz was a connecting house of nipa where in ante-insurrection days the native teachers had their quarters. At first the horde of beggars were allowed to make their headquarters in this; but on the arrival of the Division Superintendent, he protested against sowing the seeds of disease among school children in that way. So the paupers were driven forth and found shelter wherever they could, in barns and unused houses.

In the following June a part of the older pupils were separated from the others and placed in a room in the tribunal, as the nucleus of an intermediate school. I was in charge of them, and noticed one day a heap of rags lying on a pile of boards underneath the opposite wing of the building. Presently the rag heap began to twist and turn and throw arms about and then to scream. I went over to investigate, and found a girl of fourteen or fifteen nearly dead. Her skeleton body was covered with sores, her eyes seemed sightless, and the flies had settled in clouds around them and her nostrils. She would lie on the hard boards a few minutes until the torment grew unendurable, and then break into screams and lamentations. The rooms of all the municipal officers were about her, she was in full sight of the police, and yet there she lay and suffered with no human being to help her. Naturally I went to the Mayor, or Presidente. He wanted to know, with some irritation, what was to be expected when the School Superin- 
tendent refused to let the school building be used by the poor. After some talk the girl was removed to a house and assistance given her. She was past the need of food, and died in less than twenty-four hours.

The aforementioned nipa house between the two schoolhouses was utilized for janitors' quarters, and the arrangement was such that pupils leaving the room temporarily passed through it. One day one of the children casually remarked that some one was sick in there with viruela (smallpox). I went in and found a child apparently in the worst stages of confluent smallpox. Now in our own dear America this would have meant almost hysteria. There would have been head lines an inch deep in the local papers, the school would have been closed for two weeks, a general vaccination furor would have set in, and many mammas and little children would have dreamed of confluent smallpox for weeks to come. But we did none of these things in the Philippines. We merely requested the authorities to remove the smallpox pa-. tient, and ordered the janitor to scrub the room with soap and water. Nobody quitted school; nobody got the smallpox; and the whole thing was only an incident.

Later I was destined to pass through the cholera epidemic of 1902-03, and I realized how great a factor a daily paper is in creating public hysteria. Part of the time I was in Manila, where the disease was under much better control than it ever was in the provinces (where it was not under control at all), and there was 
WAR ALARMS AND SUFFERING POOR 191

about five or six times as much worry, talk, and excitement in Manila as ever prevailed outside.

I have lived in towns with newspapers and in towns without them, and have come to believe with Gilbert Chesterton that the newspaper is used chiefly for the suppression of truth, and am inclined to add, on my own account, the propagation of hysteria. 


\section{CHAPTER FIFTEEN}

THE FILIPINO'S CHRISTMAS FESTIVITIES AND HIS RELIGION

Adtumn Weather - Winter Weather - A Christmas Tree for Filipino Children - A Christmas Eve Ball - Early Mass on Christmas - Visitors - Attitude of the Filipino to Religion - His Ideas of the Fine Arts formed by the Church - Joys and Sorrows carried to Church - Religion not a Sodrce of Party Animosity - Filipinos more Likely to become Rationalists than ProtESTANTS.

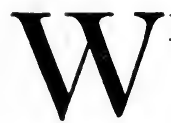

HAT with typhoons, earthquakes, talk of insurrection, the novelty of military life about us, and the effort to comprehend the native, the days sped quickly by at Capiz. October and November came and went in alternate stages of storm and sunshine. For days at a time the fine rain drove like a snow storm before a northeast wind, and it was difficult to realize that the deluge was the remnant of a great blizzard which, starting on the vast frozen plains of Siberia, had swept southward, till crossing the China Sea it gathered up a warm flood and inundated us with it. We spoke of its being autumn at home, but we could not realize the fact. When clear days came, they were so warm, so glinting with sunlight, that it seemed all the world must be 
bathed in glory. It would rain steadily for a week or ten days, and then there would come one of those clear days when every breath of vapor was blown out of the sky, the heavens were a field of turquoise, and the mountain chains were printed against them in softest purple.

With the month of December the weather changed, the rain ceased, and the dry chill winter of the tropics set in. The nights were so cold that one was glad to nestle into bed under a blanket. The northeast wind still blew, but fresh and cool from the sea, and hardly a cloud floated in the sky. We drove often out to the open beach where the surf came in gloriously, and the great mountain island of Sibullian, away to the north, hung half cloud, half land in the sky.

Christmas was near at hand, and we began to think of turkey and other essentials. Presents to home folks had to be mailed early in November, and after that an apathy came on us. Thanks to Mrs. Cthe energetic wife of a military man of private fortune, Christmas was destined to wear, after all, an Anglo-Saxon hue.

The Filipinos do not understand Santa Claus or the Christmas Tree. The giving of presents is by no means a universal custom of theirs, and such as are given are given on the festival of Tres Reyes, or The Three Kings, some six or eight days after Christmas. Mrs. C- decided to give a Christmas festival to certain Filipino children, and she actually managed to disinter, from the Chinese shops, a box of tiny candles, and the little devices for fastening them to 


\section{IMPRESSIONS OF THE PHILIPPINES}

the tree. No Christmas pine could be found, but she got a lemon tree, glossy of foliage. With the candles and strings of popcorn and colored paper flowers, this was converted into quite the natural article. She invited several of us to dinner on Christmas Eve, and we went early to see the celebration.

By half-past six o'clock, when the tropical dusk had closed down, the little guests began to arrive, each in charge of a servant. There were twenty-five twinkling, berry-eyed babelets with their satiny black down hanging like bangs over their eyes, and their tubby little stomachs covered with fine garments and bound about with gorgeous sashes. They squatted on their little heels and sucked their little thumbs, and waited in wondering patience for this strange mystery to occur. As many American children would have made the air noisy for a block around.

The windows of the house were thrown wide open, and the sliding doors which pull back all around the base boards were open too, so that the whole interior was visible from the street below. There a great crowd had gathered, men, women, and children, beggars, and many of the elder brothers and sisters of the favored guests within. Nearly every child was displaying a toy that seems to be the special evidence of Christmas in the Philippines - some sort of animal made of tissue paper and mounted on wheels. It is lighted within like a paper lantern, and can be dragged about. Great is the pride in these transparencies, and great the ambition displayed in the construction. Pigs, dogs, cats, birds, elephants, and tigers, of most weird 


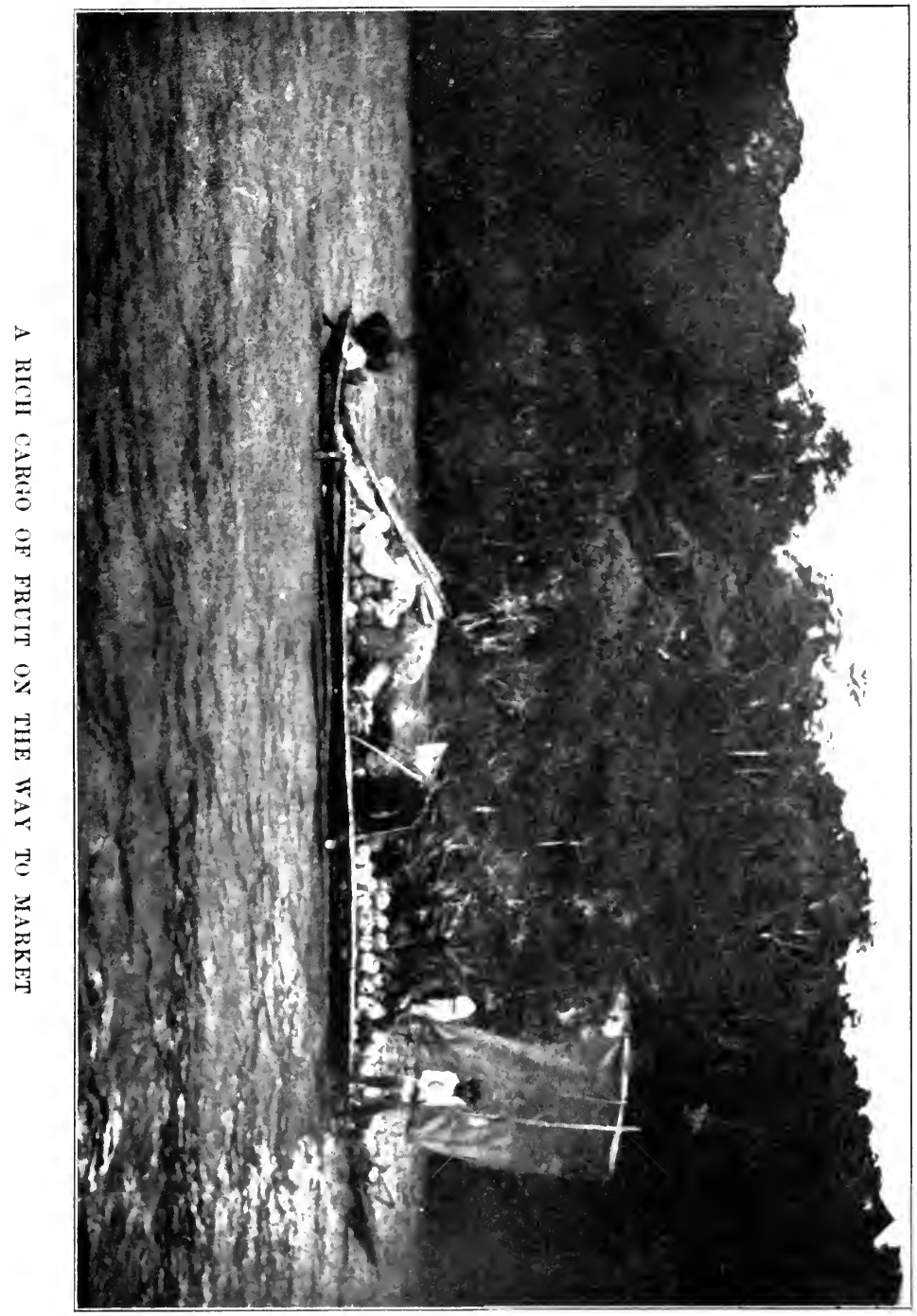



and imposing proportions they are, and no few feuds and jealousies grew out of their possession.

When the coverings were drawn off the tree, and the candles were lighted, the crowd in the street waxed quite vociferous, but the babies merely uttered little ecstatic sighs. They took their presents and turned the toys over gravely, and sucked gingerly at the sweets. Then one by one they marched out to join their relatives and the transparencies.

We had a good dinner and drank to the homeland and a merry Christmas. Afterwards Captain Cleaned out of the window and cried to us to look at the snow. The moon was just overhead, ringed round with a field of cirrus clouds. They were piled one on top of another, glistening and cool, with the sheen of real snow by moonlight. I have never seen such an effect in our own land, and only once subsequently here.

There was a ball that night, and we were all going. While we were at dinner, the waits came in and sang in the hallway just as in merry England they sing under the window. But if the English waits sing as badly as the Filipino ones, then the poetry of the wait songs is gone from me forever. These of ours were provided with tambourines, and they sang an old Latin chant with such throaty voices that it sounded as if the tones were being dragged out by the roots.

By half-past nine the local band, or one of them for most Filipino towns rejoice in half a dozen came round to escort us to the hall. This attention was, as President Harper always declared of the many 
donations to the University of Chicago, "utterly unsolicited on our part," and was the result of a hope of largesse, and of a high Filipino conception of doing honor to the stranger. Preceded by the band and surrounded by a motley assembly of several hundred people, the children dragging their transparencies with them, we strolled up the quarter of a mile of street intervening between the Lieutenant and Mrs. C_-'s house and the Filipino mansion where the ball was held. When we entered, the guests all rose to do us honor, and shortly thereafter the rigadoon was called.

The ball differed little in its essential features from other balls, save that, owing to its being Christmas Eve, the Filipino men, in accordance with some local tradition, discarded the usual black evening dress, and wore white trousers, high-colored undershirts, and camisas, or outside Chino shirts, of gauzy piña or sinamay. This is the ordinary garb of a workingman, and corresponds to the national or peasant costume of European countries; and its use signifies a tribute to nationality.

At midnight the church bells began to toll, and the three or four hundred ball guests adjourned en masse to the church. This building is larger than any I can remember in America, except the churches of Chicago and New York, and was packed with a dense throng. It was lighted with perhaps two thousand candles, and was decked from lantern to chapel with newly made paper flowers. The high altar had a front of solid silver, and the great silver candlesticks were glistening in the light, 
The usual choir of men had given place to the waits with their tambourines, though the pipe organ was occasionally used. The mass was long and tedious, and I was chiefly interested in what I think was intended to represent the Star of Bethlehem. This was a great five-pointed star of red and yellow tissue paper, with a tail like a comet. It was ingeniously fastened to a pulley on a wire which extended from a niche directly behind the high altar to the organ loft at the rear of the church. The star made schedule trips between the altar and the loft, running over our heads with a dolorous rattle. The gentleman who moved the mechanism was a sacristan in red cotton drawers and a lace cassock, who sat in full view in the niche behind the high altar. There seemed to be a spirited rivalry between him and the tambourine artists as to which could contribute the most noise, and I think a fair judge would have granted it a drawn battle.

Mass was over at one, and we went back to our ball, and the supper which was awaiting us. I shall speak hereafter of feasts, so will give no time to this particular one. Dancing was resumed by half-past two, and shortly afterwards I gave up and went home. Sleep was about to visit my weary eyelids when that outrageous band swept by, welcoming the dawn by what it fancied was patriotic music - "There 'll be a Hot Time," "Just One Girl," "After the Ball," etc. It passed, and I was once more yielding to slumber, when the church bells began, and some enterprising Chinese let off fire crackers. I gave up the attempt to rest, and rose and dressed. Then the sacristan from the church 
appeared in his scarlet trousers and cassock. He carried a silver dish, which looked like a card receiver surmounted by a Maltese cross and a bell. The sacristan rang this bell, which was most melodious, went down on one knee, and I deposited a peso in the dish. He uttered a benediction and disappeared. After him came the procession of common people, adults and children, shyly uttering their Buenas Pascuas. We had, forewarned by the sagacious Romoldo, laid in a store of candy, cigarettes, cakes, and wine. So to the children a sweet, and to the parents a cigarette and a drink of wine, - thus was our Christmas cheer dispensed. Later we ate our Christmas dinner with chicken in lieu of turkey, and cranberry sauce and plum pudding from the commissary. The Filipinos honored the day by decorating their house-fronts with flags and bunting, and at night by illuminating them with candles in glass shades stuck along the window sills.

The church in the provinces is at once the place of worship, the theatre, the dispenser of music and art, the place where rich and poor meet, if not on the plane of equality, in relations that bridge the gulf of material prosperity with the dignity of their common faith.

So far as the provincial Filipino conceives of palaces and architectural triumphs, the conception takes the form of a church. There are no art galleries, no palaces, no magnificent public buildings in the Philippines, but there are hundreds of beautiful churches, of Byzantine and Early Renaissance architecture. You may 
find them in the coast towns and sometimes even in the mountainous interior, their simple and beautiful lines facing the plaza, their interiors rich with black and white tiling and with colored glass. The silver facings of the altars and their melodious bell chimes are the most patent links which bind the Philippines to an older civilization.

As far as he has ever come in contact with beautiful music, the provincial Filipino has met it in the church. Nearly every one boasts its pipe organ imported from Europe, and in the choir lofts you may find the great vellum-leaved folios of manuscript music, with their three-cornered, square, and diamond-shaped notes. They know little of the masses of Mozart, Gounod, or more modern composers, but they know the Gregorian chants, and the later compositions of the Middle Ages. Often badly rendered - for nowhere are voices more misused than in the Philippines, - their music is nevertheless grand and inspiring.

On the walls of churches and conventos too are found pictures in oil, often gloomy, full of tortures and death, as Spanish paintings incline to be, yet essentially true art - pictures which it is to be hoped will survive the inundation of American commercial energy. The extract-of-beef advertisements and the varied "girls" of all pursuits have found their way into the Philippines; and the Filipino, to our sorrow be it said, takes kindly to them.

So far as the Filipino knows pageantry, it is the pageantry of the Church. He knows no civic processions, no industrial pomp, such as exploits itself 


\section{IMPRESSIONS OF THE PHILIPPINES}

in the Mardi Gras at New Orleans, or the Veiled Prophet of St. Louis. $\mathrm{He}$ is even a stranger to the torchlight procession of politics, and the military displays of our civil holidays. Neither the Masons, nor the Knights Templars, nor the Knights of Pythias, nor the Ancient Order of Hibernians, with their plumes and banners, have any perceptible foothold in the Philippines. But in Holy Week and certain other great festival or penitential seasons of the Church, the great religious processions take place - floats sheathed in bunting and decked with innumerable candles in crystal shades, carrying either the aitar of the Virgin or some of the many groups of figures picturing events in the life and passion of the Saviour. Almost every provincial family of wealth owns one of these cars, and the wooden figures surmounted by wax heads, which constitute the group. At the proper seasons the figures are clothed in gorgeous raiment decked with jewels, and the car is put at the service of the Church for use in the procession. The floats are placed about a hundred yards apart, and between them the people form in two parallel lines, one on each side of the street, every person carrying a lighted candle. When there are twenty or thirty floats, and half as many bands, the glitter and brilliancy of it all strikes even our satiated minds. What must it be to the untravelled child of the soil?

When the Filipinos win a fight or an election, or fall heirs to any particular luck, they do not express their enthusiasm as we do in fire crackers, noise, and trades processions. They go sedately to church and 


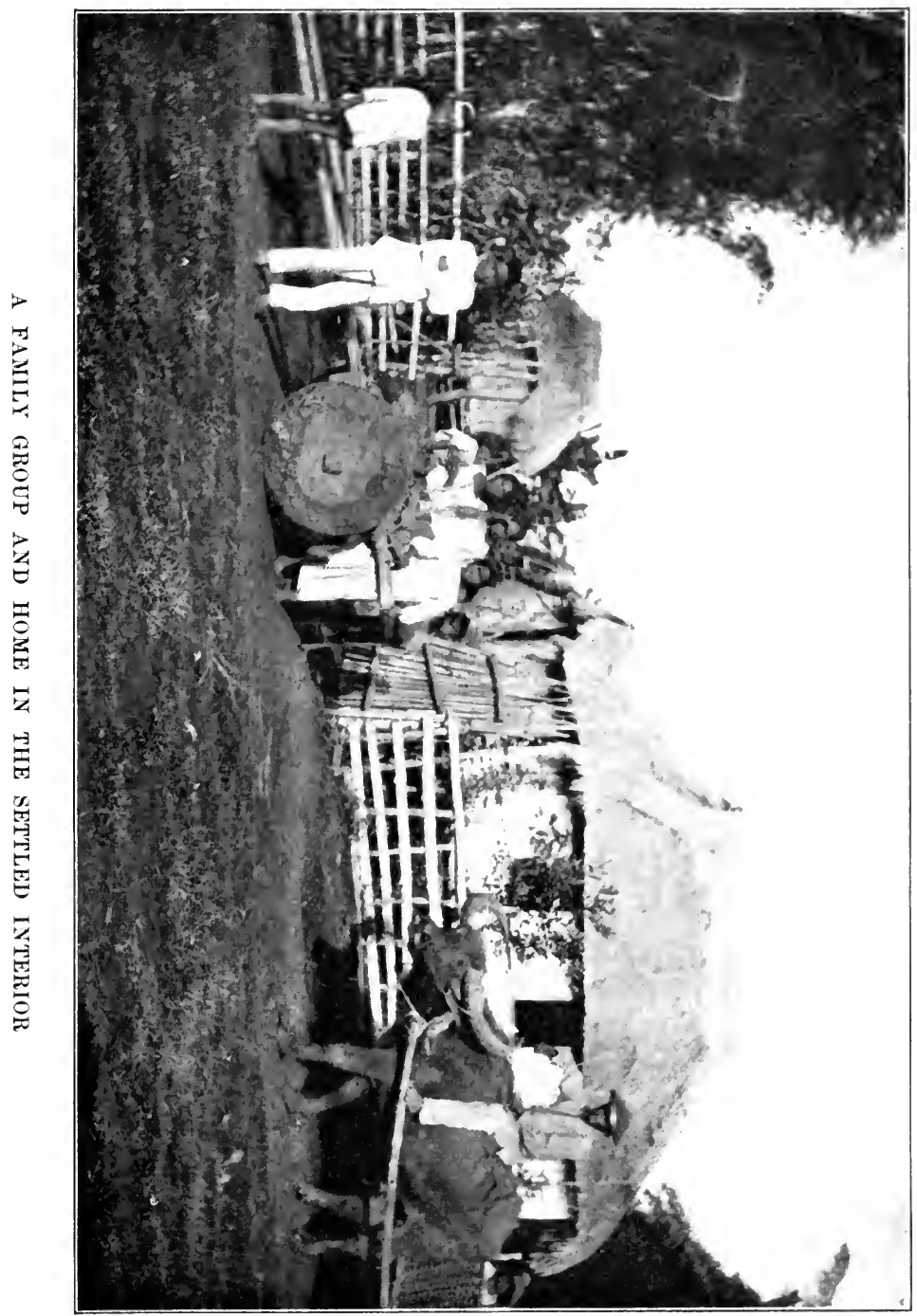



sing the Te Deum. And as we enjoy the theatre, not merely for the play, but for the audience and its suggestions of a people who have put care behind them and have met to exhibit their material prosperity in silks and jewels, so do the Filipinos enjoy the splendor of the congregation on feast days. The women are robed as for balls in silken skirts of every hue - azure, rose, apple-green, violet, and orange. Their filmy camisas and pañuelos are painted in sprays of blossoms or embroidered in silks and seed pearls. On their gold-columned necks are diamond necklaces, and ropes of pearls half as big as bird's eggs; while the black lace mantillas are fastened to their dusky heads by jewelled birds, and butterflies of emeralds, sapphires, and diamonds.

The first time I went to church in Capiz and looked down from the choir loft on the congregation, I could think of nothing but a kaleidoscope, and the colored motes that fall continually into new forms and shapes. When the results of the war had made themselves felt, and the cholera had ravaged the province, this variety of color was lost, and the congregation appeared a veritable house of mourning. This was not, however, due to the appalling mortality, but to the Filipinos' punctilious habit of putting on mourning. When death visits a family, rich or poor, even the most distant relatives go into mourning, and they cling to it for the required time.

If the reader will take into consideration all that I have said about the part played by the Church in Filipino life, and at the same time consider their 
insular isolation, their lack of familiarity either through literature or travel with other civilizations, he will readily perceive that religion means a totally different thing in the Philippines from what it does in America, even in Roman Catholic America.

To the complacent Protestant evangelist who smacks his lips in anticipation of the future conquest of these Islands, I would say frankly that there is no room for Protestantism in the Philippines. The introspective quality which is inherent in true Protestantism is not in the Filipino temperament. Neither are the vein of simplicity and the dogmatic spirit which made the strength of the Reformation. Protestantism will, of course, make some progress so long as the fire is artificially fanned. There will always be found a few who cling ardently to it. But most Americans with whom I have talked (and their name is legion) have agreed with me in thinking that it will never be strong here.

The attitude of the Filipino Catholic is at once tolerant and positive. It is positive because without any research into theological disputes the ordinary Filipino is emotionally loyal to his Church and satisfied with the very positive promises which that Church gives him. It ministers not only to his spiritual but to his material needs on earth, and it promises him in no circumlocutory terms salvation or damnation. It either gives him or denies him absolution. He believes in it with the implicit faith of one who has never investigated. On the other hand, he is tolerant with the tolerance of one who has in his blood none of the 
acrimony begotten by an ancestry alternately conquerors and victims through their faith. The Filipino Catholic is far more tolerant than the Irish or German Catholic. But the Philippines have known no battle of the Boyne, no Thirty Years' War. When the abuses of the friars here led to revolt and insurrection, the ultimate outcome of the struggle would have been probably a religious secession from Rome, as well as political severance from Spain, had not the accident of the Spanish-American War precipitated us upon the scene, and settled the matter by the immediate expulsion of the Spanish Government. The only real point of infection left to create a sore in the new body Filipino - the friar lands - was fortunately so treated by Secretary Taft that it ceased to menace the State or threaten to mingle religion with government.

The Filipinos are tolerant of Protestantism because to them it is still a purely religious and not a civil influence. They have not killed or been killed for religion; for it they have not burnt the homes of others, nor seen their own rooftrees blaze; they have not gained power or office through religion; they have neither won nor lost elections through it. They have the same tolerance in religious matters that they have in regard to the Copernican Theory or Kepler's Laws. Religion, as pure religion, unrelated to land or land titles, property or office, is no more the source of party animosity to them than to us. Secretary Taft was wise enough to see that, and eliminated the cause that threatened to make religion a vital question. 


\section{IMPRESSIONS OF THE PHILIPPINES}

But if religion is not consciously vital to the Filipinos, as they themselves would conceive and act on it (and I make the assertion in the assumption that the reader understands as I do by consciously vital that for which the individual or the race is willing to die singly or collectively), the unprejudiced observer must admit that it is vital to their ultimate evolution, vital in just the sense that any function is vital to one who is in need of it. As I said before, they are not essentially a religious people; but the early Spanish discoverers prescribed religion as a doctor prescribes a missing ingredient in the food of an invalid, and the Filipinos have benefited thereby. Roman Catholicism is just what the Filipino needs. He has no zest for morbid introspection, he does not feel the need of bearing testimony to cosmic truth, and in his lack of feeling that need is just as helpless as the man whose system cannot manufacture the necessary amount of digestive juices or red blood corpuscles; he is an invalid, who must be supplied artificially with what his system lacks.

I am quite sure that the Catholic clergy, as represented by the American Archbishop, bishops, and priests, are certain that Protestantism holds no threats for the Church in the Philippines other than that it may be the opening wedge in a schism which will send the Filipino not only out of the Church, but to rationalism of the most Voltairian hue. When danger really threatens the Church in the Philippines, it will be no half-way danger. The Filipino will be orthodox as he is now, formally, positively orthodox, or he will be 
cynically heterodox. As God made him, he might in time have arrived at the philosophy of Omar, "Drink, for ye know not why or when," or the identical philosophy of Epicurus, "Let us eat and drink, for tomorrow we die." But the Church found him, and recognizing his peculiarities artfully substituted her own phrase, "Eat and drink in peace, for to-morrow you die in the full knowledge that pertains to your salvation." Let no proselyting evangelist delude himself with the idea that the Filipino has the mental bias which leads him to think, "Let me neither eat nor drink till I know whence I came and whither I go." That is the spirit of true Protestantism, which discovers a new light on faith every decade and still is seeking, seeking for the perfect light.

But if the Church in the Philippines is in no real danger from Protestantism, it is in more or less imminent danger from two sources - the necessity for reform in the Church itself, and the growing national sense of the Filipinos, which leads them to demand their own clergy, and to resent to the point of secession a too firm hold by the new American clergy. 


\section{CHAPTER SIXTEEN}

\section{MY GOLD-HUNTING EXPEDITION}

Word of an Abandoned Gold Mine near Manila - I arise Before three A. M. AND FIND THE TOWN AsleEP-OUR Trip down the River-Scenery and Sights by the Way - Three Buffaloes are brought to Drag us over THE Mud - Digging for Gold - I fall as an Overseer of Diggers - Results of the Digging Unsatisfactory - The Homeward Trip.

FTER Christmas we settled down to humdrum
work, and barring my gold-hunting experi-
ence there was little to relieve the daily monotony of existence. I wrote an account of the gold-hunting expedition as one of a series of newspaper articles published in The Manila Times. With the consent of the editors, I now transcribe it bodily here, for, without any gleam of romance or adventure, the experience was one typical of the land and of our life here, which I believe the generous reader will be willing to accept without any attempt on my part to embellish it with excitement and lurid writing.

Our Supervisor had gotten hold of a legend of an abandoned mine in a mountain some four or five miles from town. According to the native story, half a century or more before this period the mine was worked, and considerable quantities of gold were taken out of it. But dissensions arose between the barrios 
that supplied the labor, and finally the native priests ordered the shaft to be filled and closed, and all work to cease, lest it bring a curse upon the people. They obeyed, and the mining interests thereabouts fell into oblivion.

The Supervisor had, with native assistance, located the spot, and made a few crude washings in which he found "color." Then he came back to make a sluice box, and, together with a young lieutenant of constabulary, intended to pass the Sabbath day in further investigation of the mine's possibilities.

The occasion was too tempting. I promptly laid siege to the Supervisor's wife, pleading that she induce her liege to let us accompany him. As he was goodnatured and the trip was short and easy, he consented. We were to leave town in a baroto at three A. M. to get the benefit of the tide. At half-past nine the night before, the lunch basket containing my contribution to the commissary department was packed and suspended from the ceiling by a rope, protected by a petroleumsoaked rag, and I went to bed to dream of gold mines, country houses, yachts, and European travel. It was ten minutes to three when I scrambled out in a great fright lest I should be late and keep the others waiting. I lighted the alcohol lamp to boil the coffee, and flew into my garments. But I dressed and ate and still they came not. So I poked my head out of the window into the sad radiance of a setting moon.

It was a town sleeping peacefully, and yet with every hint of warlike preparation that scattered itself along the river. In front of the officers' quarters a sentry 
clanked up and down the pavement. From the military jail came a sound of voices and the creaking of benches, as the guard turned on the hard bamboo seats, mingled also with a steady tramp. More sentries could be seen across the river, where the troop barracks loomed up and almost hid the hills which gloomed over the town. The bridge was in shadow, but now and then a tall figure, gun on shoulder, emerged at its farthest end into a pale little dash of moonlight. The lanterns which the Filipinos hang out of their front windows in lieu of street lamps burned spectrally, because they were clogged with lamp black. And the brooding and hush of night were disturbed only by the rhythmic footfalls, or by the occasional slap of a wave against the bridge rests, or by a long shrill police whistle which told that the municipal police were awake and complying with the regulation to blow their whistles at stated intervals for the purpose of testifying to the same. It was all full of charm and suggestion, singularly like and singularly unlike an American village under the same conditions of light and temperature.

The moon sank so low that the mists caught it and turned its sheen into a surly red. Presently a sentry challenged up by the jail, and then the glint of white clothing grew distinct. I unhooked the lunch basket and prowled my way out of the house, seeking to disturb nobody and feeling quite adventurous.

Our baroto with six native oarsmen was waiting at the stone stairway in the shadow of the bridge, and as the tide was beginning to turn we lost no time in 
bestowing ourselves and our provisions. The middle of the baroto, for a distance of about six feet, was floored and canopied. Mr. L- took the far corner, his wife pushed herself and a couple of pillows up against him; then I braced myself and my pillows against her; and the unfortunate lieutenant fell heir to the fate of an obliging young gentleman and was stowed away at the end, supported (or incommoded) by the lunch baskets and an unsympathetic soap-box filled with water bottles. The men unslung their revolvers, and we disposed ourselves so as to secure a proper equilibrium to our tippy craft, and were off.

We slipped down the river, aided by the tide, and in a few minutes were far away from the last house, the last gleam of light, and the least sound of human life. Save for the soft dip of oars, not a sound broke the night. Yet it was not silence so much as the sense of deep respiration, as if the earth slept and sent up an invocation to the watching heavens. The banks were thickly weeded at the water's edge with nipa, and behind that were knolls of bamboo with here and there a gnarled and tortured tree shape silhouetted against the faint sky. Occasionally we came to a convention of fireflies in that tree which they so much affect, the name of which is unknown to me, but which in size and outline resembles a wild cherry. Millions of them starred its branches, and in the surrounding gloom it winked and sparkled like a fairy Christmas tree.

We talked little, and were content to drink in the silence and the strangeness, till by and by the wind 
fell cooler and we knew the dawn was at hand. It seemed to come suddenly, bursting out of the east in a white glare, without the pearly tints and soft gray lights that mark our northern day births. Then the white glare changed to red, to a crimson glow that painted the world with its glory, and dying, left little nebulous masses floating in the azure, tinted with pink, gold, and purple.

With the first touch of light we turned out of the main river, which was now a broad estuary as it neared the sea, and fled down a water lane not over fifteen or twenty feet wide, absolutely walled with impenetrable nipa growths. From this we emerged just as the day played its last spectacular effects, and found ourselves in a deep oval indentation, glassy as an inland lake, whose bosom caught the changing cloud tints like a mirror, and whose deep cool green borders were alive with myriads of delighted birds, skimming, chattering, calling. Half a mile away, at its farther end, the surf leaped frothily over a bar, and beyond that the open sea tumbled and flashed in the first sun-rays. It was idyllic - and on our left a mere stone's throw, it seemed, behind the embowering forest, the mountain of our quest thrust a treeless, grassy shoulder into the blue.

Mr. L_- however, warned us that our way was still long and circuitous. We crossed the lagoon and went wandering off down a green, silent waterway which rejoiced in the appellation of "kut-i-kut" and proved itself unworthy of the same. The tide was going out rapidly, and the water mark on the tree 
trunks was growing high. Sometimes we met a baroto on its way to market with a cargo of three chickens, five cocoanuts, two bunches of bananas, one head of the family, four children, and several women unaccounted for. The freight was heaped at one end, and the passengers all squatted in that perfect, uncommunicative equilibrium which a Filipino can maintain for hours at a time. Sometimes we came out where there were almost a hundred square yards of ground and two or three houses and the stir of morning life. Ladies with a single garment looped under their arm pits were pouring water over themselves from cocoanut shells, and whole colonies of game-cocks were tethered out on the end of three feet of twine, cursing each other and challenging each other to fights. The male population almost to a man was engaged in the process of stroking the legs of these jewels, to make them strong, and some of the children were helping.

As a rule, our advent generally disturbed these morning devotions, for American women were still comparatively new and few in the province at that time. A shout, "Americanas!" usually brought the whole village to the waterside, where they bowed and smiled and stared, proffering hospitality, and exchanging repartee with the lieutenant, who used the vernacular.

Meanwhile the tide went out and out, and we sank lower and lower in kut-i-kut till we were in a slimy ditch with four feet of bank on each side. The turns and twists grew narrower, and the difficulty of steering our long baroto around these grew greater. The 


\section{IMPRESSIONS OF THE PHILIPPINES}

men got out and waded, pushing the baroto lightly over the soft ooze. But finally this failed. It was eight o'clock, the sun climbing higher and burning fiercer, when we stuck ignominiously in the mud of kut-i-kut.

After a short consultation the lieutenant sighed, cast a glance at the mud and his clean leather puttees, then went overboard, taking a man with him. They disappeared in the nipa swamps, but came back in half an hour with three carabaos, their owners, and an army of volunteers.

Our motive power, being hitched tandem, now extended round a couple of bends, and there ensued the wildest confusion in an endeavor to get them all started at the same time. Apparently it could n't be done, and we wasted a half-hour, in which every native in the swamp seemed to be giving orders, and the overwhelming desire of the carabaos was to swarm up the bank and get out, without regard to the effect on the baroto. The lieutenant had come aboard and was sitting on the high prow dangling his muddy leggins ahead. To him Mr. L__ in disgust suggested that the taos were making little real effort and that he "stir 'em up." So the lieutenant drew his revolver and at a season of discord aimed it carefully in the high distance and fired.

The effect on the humans was just what he desired, but he did not allow for the nervousness of the carabaos on hearing a revolver shot in a locality where it is distinctly not native. The unanimity that had so long been sought swept like an epidemic into our lum- 


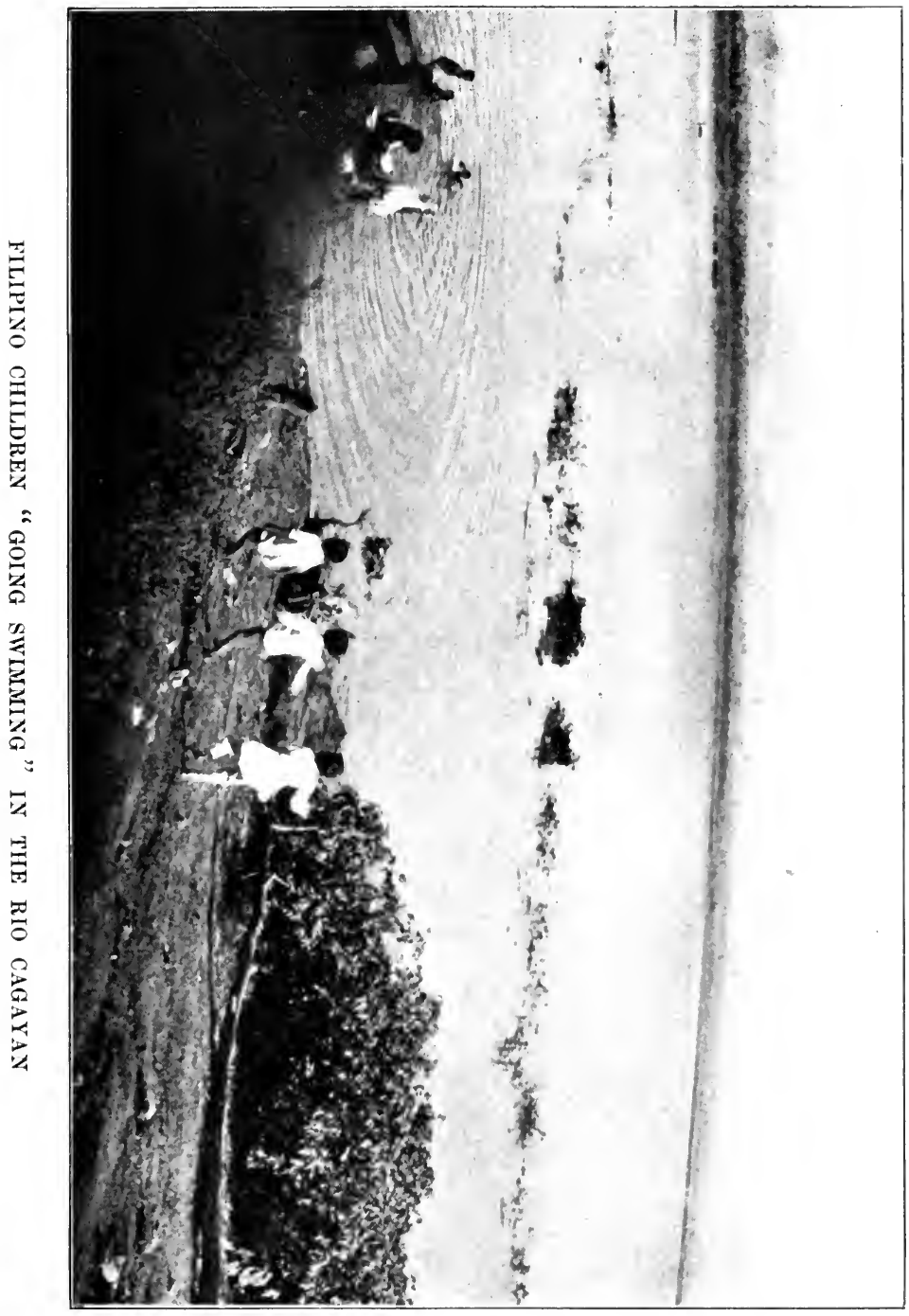



bering steeds, and our baroto started ahead with a firmness of purpose that sent the author of this book flying into the mud, and bumped us all up most gloriously as we lunged round the corner. The good work once begun was not allowed to fall slack, however. The lieutenant caught up and climbed aboard, and we swept through the three miles of kut-i-kut in a wild cavalcade, rolling like a ship in a storm. At its end we struck upon water, and parted from our long-horned ayudantes.

A short row up a narrowing stream brought us to the place of disembarkation, an open grassy field which swept down from a cleft between the mountains. We walked across this till we came to a brook purling out of cool green shadows, and after following it in a rather stiff climb for about forty-five minutes, came to the scene of investigation.

There, the week before, the men had built a dam, and had thrown a rough framework and shelter across the bed of the stream. This they now covered with freshly cut boughs and leaves, and Mrs. L_- and I were only too glad to spread our pillows and lie down for a few minutes in the cool shade with the water bubbling and murmuring underneath. I was pretty well done with the heat and the unaccustomed exercise, but was soon rested and helped to make the coffee. That was a good meal, spiced with waiting, and immediately after we went at the business at hand.

The men set up the sluice box, which the taos had brought along with labor and disgust, and giving me 


\section{IMPRESSIONS OF THE PHILIPPINES}

a revolver, commissioned me to see that the excavating department kept busy. So I sat on the edge of a twenty-foot bank clasping the Colt, and hanging my feet into vacancy. I had n't felt so close to childhood for many a long year.

For an hour or so all went well, and the cheerful tao dug and delved and carried without murmur. Then his diligence subsided and there was a talk of "siesta." Somebody down at the sluice box shouted, "Keep busy up there"; so, after one or two efforts to hurry up our minions, I pointed the pistol carefully into the ground and fired. They all jumped prodigiously and looked around. But I could n't play the part. I did n't look stern, and I simply sat there grinning fatuously with the sense of my own valor, whereupon the taos burst into a shout of laughter and seemed to think a bond of friendship had been established between us. They got lazier and lazier and smiled at me more and more openly, and made what I judged to be remarks about my personal appearance. So at another convenient opportunity I let off another shot, which was a worse fizzle than the first. One old fellow whose back was glistening with sweat turned and winked at me, and another pretended to hunt for imaginary wounds.

Recognizing that I was an ignominious failure in the public works department, I left it to manage itself and strolled over to add my inexperience and ignorance to the sluicing agency.

Mrs. L- had anticipated me and was already advising the willing workers when I appeared. On the whole, they were pretty patient about it all, and 
let us ask innumerable questions and make suggestions (which, however, they never observed) ad libitum.

But however little I knew about gold-mining, I have shared one thing with the real prospector - the eager, fascinated, breathless suspense of staring into a fold of blanket for "color." When we really saw a vagrant glint here and there, what delight! - delight easily quenched by Mr. L-, however, who declared the yield too small for a paying basis.

All that hot summer day, we dug and washed and watched, but with unsatisfactory results. In the longshadowed afternoon we packed traps and set off down the valley. The egrets, camping by dozens on feeding carabao, flapped away as we approached; we found our baroto as we had left it, rising gently on the incoming tide in the shade of a clump of bamboo.

The homeward journey, if not one of resignation to the will of Providence, had its compensation in the loveliness of afternoon lights and the cool, peaceful silence of the forests. We avoided the insidious snares of kut-i-kut, but found our lagoon just bestowed for the night, snug, glassy, with the dusk creeping on and on. Thence we passed into the open sea, were cradled gently into our own bay, and saw the coastguard station at the inlet send ruddy gleams across the water, beneath the lowering form of the hill. Once in the river, we fairly flew along, bathed in moonlight. We neared home, heard bands playing in the distance, and, with sudden remembrance that it was a native fiesta, turned the bend and saw a fairy city aglow with lanterns, where eighteen hours before had been silence 
216 IMPRESSIONS OF THE PHILIPPINES

and stealth. All the craft in the river were hung witk multicolored lights, and the people were out promenading, while a crowd of school children, sitting on the river bank, were singing "Old Kentucky Home" in four parts.

It was a happy day, one of those photographic experiences to be treasured forever, but the dream of yachts and country houses never has become a reality. If an energetic prospector wishes to try, he will find in a cleft between two tall mountains an abandoned shaft and the remains of a dam spanning a mountain stream. But let him not taste of the babbling water. I did, and put in six weeks of illness therefor. 


\section{CHAPTER SEVENTEEN}

\section{AN UNPLEASANT VACATION}

The Inspector's NightLy Bonfires - OUR Vacation in Manila and in Quarantine - After our Return to Capiz Cholera breaks out-Record of our ExperienCES DURING the EPIDEMic.

CCHOOL closed in March, and Miss $\mathrm{C}$ - and I decided to spend our vacation in Manila. We were to leave Capiz on the small army transport Indianapolis and go to Iloilo, thence by the Compañia Maritima's boat to Manila.

The Indianapolis was carrying an inspector around the island, which gave us a four days' trip to Iloilo. The sea was perfectly smooth and the nights brilliant moonlight. We ran from town to town wherever a military detachment was stationed, and the inspector went ashore and inspected. This rite usually culminated in a huge bonfire on the beach, in which old stoves, chairs, harnesses, bath towels, and typewriters were indiscriminately heaped. I remarked once with civilian density that this seemed a most extravagant custom. If the army did not want these things longer, why not let them fall into the hands of others who could patch them up and make use of them?. The captain of the transport explained to me that all condemned articles must be irretrievably destroyed to prevent 


\section{IMPRESSIONS OF THE PHILIPPINES}

fraud in subsequent quartermasters' accounts. For example, if a quartermaster has a condemned stove which is not destroyed, he can sell a perfectly new stove, and on the next visit of the inspector present again the condemned article to be recondemned, and continue to follow this practice till he has robbed the Government of hundreds of thousands of dollars. Of course it was plain enough after the explanation, and I wondered at my stupidity.

Our four days' trip around the island was uneventful save for the nightly bonfires of the inspector. Once at San Joaquin a fine military band came down to the beach and played for an hour in the silver moonlight. I enjoyed immensely the music, the bonfire (which was burning enthusiastically), the wonderful light, the tranquil expanse of the China Sea, and the delicate spire of the village church, rising in the ethereal distance from glinting palm fronds. Nothing is more beautiful than the glisten of moonlight on palms.

Arrived at Iloilo, I was taken ill almost immediately with the prevailing tropical evil, dysentery, presumably the result of drinking spring water on the gold hunt. At the same time there came down the report that cholera was epidemic in Manila. Nevertheless, when I was able to travel, to Manila I went, and there loathed myself, for it was blistering hot. I was staying at a hotel in the Walled City, and the great yellow placards announcing cholera were to be found on houses of almost all streets in the vicinity. But when I was ready to leave, the full evil of a cholera epidemic made itself apparent. There was no getting out 
of Manila without putting in five days' quarantine in the bay.

We went aboard on the twenty-seventh of May. The steamer pulled out into the bay and dropped anchor. We were paying five pesos a day subsistence during this detention, and yet we were supplied with no ice and no fresh meat. We consumed the inevitable goat, chicken, and garbanzos, the cheese, bananas, and guava jelly, and the same lukewarm coffee and lady-fingers for breakfast. Owing to the heat, and the lack of fans, the staterooms were practically impossible, and everybody slept on deck either on a steamer chair or on an army cot. The men took one side of the deck, and the women the other. By day we yawned, slept, read, perspired, and looked longingly out at Manila dozing in the heat haze. There were several Englishmen aboard, and they were supplied with a spirit kettle, a package of tea, some tins of biscuits, and an apparently inexhaustible supply of Cadbury's sweets, which they dispensed generously every afternoon. They had also a ping-pong outfit, and played.

Every day the doctor's launch came out to see that none of us had escaped or developed cholera, and it brought us mail. Decoration Day was heralded by the big guns from Fort Santiago and the fleet at Cavite, and as I recalled all the other Decoration Days of my memory, the unnaturalness of a Decoration Day in the Philippines became more and more apparent.

Our quarantine was up on Sunday morning, but at the eleventh hour it was noised about that we should not leave, because a lorcha which we had to tow had 
failed to get her clearance papers. Our spirits descended into abysmal infinity. We felt that we could not endure another twenty-four hours of inaction.

The lorcha was a dismasted hull, no more, with a Filipino family and one or two men aboard to steer. We had a Scotch engineer who might have been the original of Kipling's McFee. I spoke to him about the rumor as he leaned over the side staring at the lorcha, and he gave vent to his feelings in a description of the general appearance of the lorcha in language too technically nautical for me to transcribe. At the end he waxed mildly profane, and threatened to "pull the dom nose out of her" when once he got her outside of Corregidor.

The rumor proved a canard, however, and we lined up at eleven o'clock, while the doctor counted us to see that we were all alive and well. Then up anchor and away, with the breeze born of motion cooling off the ship.

The engineer was not able to keep his dire threat about the lorcha's nose, but it is only just to say that he tried to. We met a heavy sea outside of Corregidor, and never have I seen anything more dizzy and drunken and pathetic than the rolls and heaves of the loreha.

At Iloilo we met the army transport McClellan, and continued our voyage upon her to Capiz. We bade farewell to her with regret, and consumed in an anticipatory passion of renunciation our last meal with ice water, fresh butter, and fresh beef. The McClellan took away the troops of the Sixth Infantry and the 


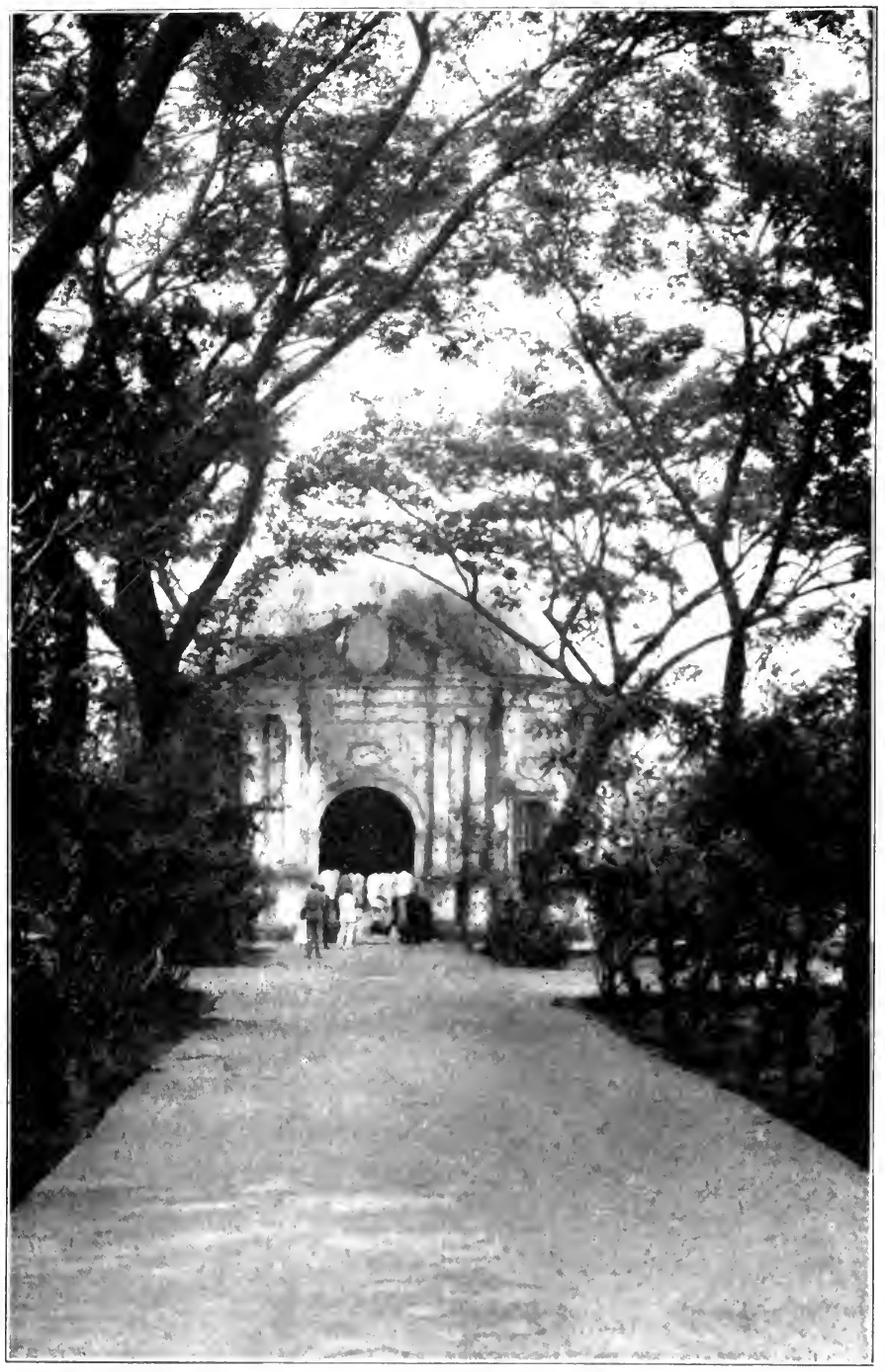

MORTUARY CHAPEL IN PACO CEMETERY, MANILA 

Tenth Cavalry, and left us, in their stead, a detachment of the Ninth Cavalry, which remained perhaps two months, and was then stationed at Iloilo, leaving us with nothing but a troop of native voluntarios, or scouts, officered by Americans, and a small detachment of native constabulary. We had barely accustomed ourselves to this, and ceased to predict insurrection and massacre, when the cholera, which we had hoped to avoid, descended upon us.

I am sorry that I can relate no deeds of personal heroism or of self-sacrifice in the epidemic. There did n't seem to be any place for them, and I am not certain that I knew how to be heroic and self-sacrificing. I was not, however, so nervous about the cholera as some Americans were, and I like to convince myself that if any of my friends had sickened with it and needed me, I should have gone unhesitatingly and nursed them. Fortunately (or unfortunately for the proof of my valor) this was not the case. The scourge stayed with us between two and three months. The highest mortality was between a hundred and a hundred and fifty deaths a day, and by its ravages Capiz was reduced from a first-class city of twenty-five thousand inhabitants to a second-class city of less than twenty thousand. I kept a brief record, however, of our experiences during that time, and once again, by permission of The Times, insert them here.

September 8. Miss P-, Dr. B-, and I were out for a long walk this afternoon. They left me at my door just as Mrs. L_- and Mrs. T_- drove up in the latter's victoria. Both ladies were much excited 
by the news that a parao had landed at the playa with one dead man and a case of cholera still living. The other people of the parao had scattered before the health officers got hold of the matter.

September 9. The story about the parao has been confirmed. We had hoped to escape the epidemic, but are in for it now, for certain.

September 10. It is rumored that two eases of cholera developed yesterday. Dr. B- denies it, says they are nothing but acute dysentery. Dr. $\mathrm{S}-$ thinks they are cholera.

September 11. Whatever this illness be, it kills people in a very short time. A little public-sehool boy was taken sick last night, and died in three or four hours. Natives are terribly frightened, and we Americans are far from comfortable.

September 12. Several more deaths. Dr. S- says cholera. Dr. B- says if there has been a case of cholera in town he will eat his hat. They are making every effort to find out what it is, but the bacillus is shy, and refuses to respond to the searchings of the microscope.

September 13. Cholera increasing. Dr. B- has given in at last. A scout died, and they made an examination of the stomach and bowels. Found the bacillus. Dr. B - says if I will come around to the hospital, he will show me one.

September 14. Have seen the comma bacillus. It is certainly an insignificant microbe to be raising so much trouble. Got hold of a report from the Board of Health, saying that, if the epidemic grew worse, the public school buildings should be converted into hos- 
pitals. Took it over to the Deputy Division Superintendent to protest. Schoolhouses are scarce here. Cannot afford to infect them.

September 15. The schools are closed to-day, the number of deaths having passed ten per diem. As I am the only householder, the other teachers are to have their meals with me till the epidemic is over.

September 16. The house smells to high heaven! The provincial Supervisor came in this morning with a quart of crude carbolic acid, about half a bushel of chloride of lime, and a lot of camphor. I immediately put the camphor in my trunks, having wanted some for quite a little time, and devoted the rest of the stuff to its proper uses. Put the lime over the stone flagging below, with a large heap at the foot of the stairs, so that everybody coming in must walk through it. The floors and stairs are frightfully tramped up. Ciriaco, much to his disgust, had to wash off all the furniture with agua finecada (diluted carbolic acid). Bought a new kettle in which to boil the drinking-water. Bought yards and yards of new tea towelling, and gave orders that, after being once used, the dish towel is to be boiled before using again.

September 18. Dr. S- says get nothing out of the market. Dr. B- says he eats cucumbers three times a day. What the doctor can risk surely the layman can chance. I buy cucumbers still. On being brought into the house they are washed in diluted carbolic acid, and rinsed in boiled rain water. Then the servant washes her hands in bichloride solution, peels the cucumber, slices it and lets it stand in vinegar till 
meal time. Dr. V- says the vinegar is sure death to the shy bacillus.

September 19. All the change is deposited in agua finecada when the servant comes in from market. What could we do without cucumbers? How weary we are of the canned stuff from the commissary! It is rumored that Dr. S- and wife will not eat butter, because it must stand too long. Mrs. S- bakes her own bread, and, it is reported, locks her cook up at night for fear he may escape and visit among his kindred. He is not allowed to leave the premises by day.

Miss P— tells me that at Mrs. T_-'s the visitor is requested to scrape his fect in the chloride of lime at the foot of the stairs, and, on arriving at the top, is presented with a bowl of agua finecada, wherein to wash his hands. The towel has been boiled, and, of course, a fresh one is provided for each person. This is not so extravagant as it sounds. We Americans are few in number, and do but little visiting these days.

October 3. Saw four cholera patients carried past to-day. The new cholera hospital is now open, and a credit to the town. Deaths average about fifty per day. The town is unutterably sad. Houses are closed at dusk, and not a gleam of light shines forth where there used to issue laughter and song. The church, which used to resemble a kaleidoscope with the brighthued raiment of the women, is now filled with kneeling figures in black. So far, the sickness has not touched the principales. Only the poor people are dying. There is a San Roque procession every night. Fifty or a hun- 
dred natives get a lot of transparencies and parade in front of the altars of the Virgin and San Roque. A detachment of the church choir accompanies, caterwauling abominably. It is all weird and barbaric and revolting - especially the "principal" in a dress suit, who pays the expenses, and, with a candle three feet long, paces between the two altars. I always set three or four candles in my windows, which seems to please the people.

October 6. Mr. S—, being a member of the Board of Health, has been engaged in inspecting wells. The natives are now saying that he poisoned them. $\mathrm{He}$ is indignant, and we are all a little uneasy. We are a handful of Americans - fifteen at the most. We have little confidence in the native scouts, though their officers insist on their loyalty. We are twenty-four hours from Iloilo by steamer, and forty-eight from Manila, and are without a launch at this port. In case of violent animosity against us, the situation might become serious.

October 7. At dinner last night, Mr. S— said there had been an anti-American demonstration in the market, and that a scout had cried, "Abajo los Americanos!" That settled me. I lost my nerve completely, and went up and asked Dr. and Mrs. S- to let me spend the night at their house. They were lovely about it, and salved over my mortification by saying that they wondered how I had been able to stand it so long, alone in the native quarter. Slept badly in the strange house, and am afraid I gave much trouble.

October 8. Got some command of my nerves last 
night, and stayed at home, though I asked the officer commanding the constabulary for a guard. He was most accommodating and outwardly civil, though it was apparent he thought I was making a goose of myself. The guard came, in all the glory of khaki, redshoulder-straps, 45-calibre revolver, and rifle - don't know whether it was a Krag or a Springfield. At any rate, he was most imposing, and, as he unrolled his petate on the dining-room floor, assured me in broken Spanish that he would protect me to the last. I bolted my door and went to bed. Slept wretchedly, being, it must be confessed, about as much afraid of the guard as of the possible anti-Americanos.

October 9. Last night, decided that I had yielded to my nerves long enough. Stayed at home, and did n't ask for a guard either. Being much exhausted by two nights of wakefulness, slept soundly all night. To-day the world looks bright and fresh, and my late terrors inexplicable.

October 12. Poor M- has the cholera. His duties as a road overseer have taken him into the province, and he has been forced to eat native food. He got a bottle of chlorodyne and seemed to feel that it would save him. But to-day he is down. Mr. S- brought the news when he came by to take me for an afternoon walk. He met the inspector and the padre, coming from M_-'s house. Extreme unction had been given him and all hope of recovery was gone, though both American physicians had been with him all day and were making every effort to save him. He asked for Mr. S_- so the latter left me to go to his bedside. 
At seven o'clock Mr. S- went by in the dusk, and called to me from the street to send his dinner up to his house. Poor M- had just died. Mr. Sheld his hand to the last, and was on his way home to burn his shoes and clothing and to take a bath in bichloride.

Most of the American men went in to see M-. I am glad of it. It may not be sanitary, but it is revolting to think of an American dying alone in a Filipino hut.

M- was buried to-night. I saw the funeral go by. First came the body in the native coffin, smeared with quicklime. The escort wagon loomed up behind in the starlight, full of American men, and then came the scout officer and his wife in the spring wagon. $\mathrm{M}-$ was once a private in the Eighteenth Infantry.

Just after this mournful little procession went by with its queer muffled noises, the big church bell boomed ten, and the constabulary bugles from the other end of the town blew taps. The sound came faintly clear on the still night air, and the tall cocoanut tree that I love to watch from my window drooped its dim outline as if it mourned.

October 15. The weather remains bright and hot in spite of our continual prayers for rain. The natives say a heavy rain and wind will "blow the cholera away." The deaths have now swelled to more than a hundred a day, though the disease remains largely among the poor. Yesterday I saw a man stricken in the street. He lay on his back quite still, but breathing in a horrible way. The bearers came at last and carried him away on 


\section{IMPRESSIONS OF THE PHILIPPINES}

a stretcher. Two cases were taken out of the house next door to me.

October 16. Ceferiana professed to be ill this morning, and I was alarmed. I dosed her with the medicine which Dr. S— had given me when the epidemic first appeared, and sent for the Doctor himself. But I discovered, before he came, that she had gotten too close a whiff of the chloride-of-lime bag, and it nauseated her. She is more afraid of the disinfectants than of the disease.

October 20. Have had to chastise Tomas, and have thus violated Governor Taft's standards for American treatment of our brown friends. Tomas is about forty and the father of a small boy, and Mr. S-, who contemplates setting up a bachelor's establishment when the epidemic is over, fondly dreams that Tomas embodies the essentials of a cook. So Mr. S- brought Tomas down, accompanied by his son, a child of twelve, with the request that I train them for him. I set them first to washing dishes, and had a struggle of a week or so's duration in trying to adjust Tomas's conception of that labor to my own. I particularly ordered that no refuse was to be thrown in the yard or under the house. This rule was violated several times, and my patience pretty well exhausted. I stepped into the kitchen this morning just in time to see Tomas doubling over, and poking the coffee grounds down between the bamboo slats of the flooring. The American broom was handy, and the angle of Tomas's inclination was sufficient to expose a large area of resisting surface. So I promptly "swatted" Tomas with the broom with such energy that 


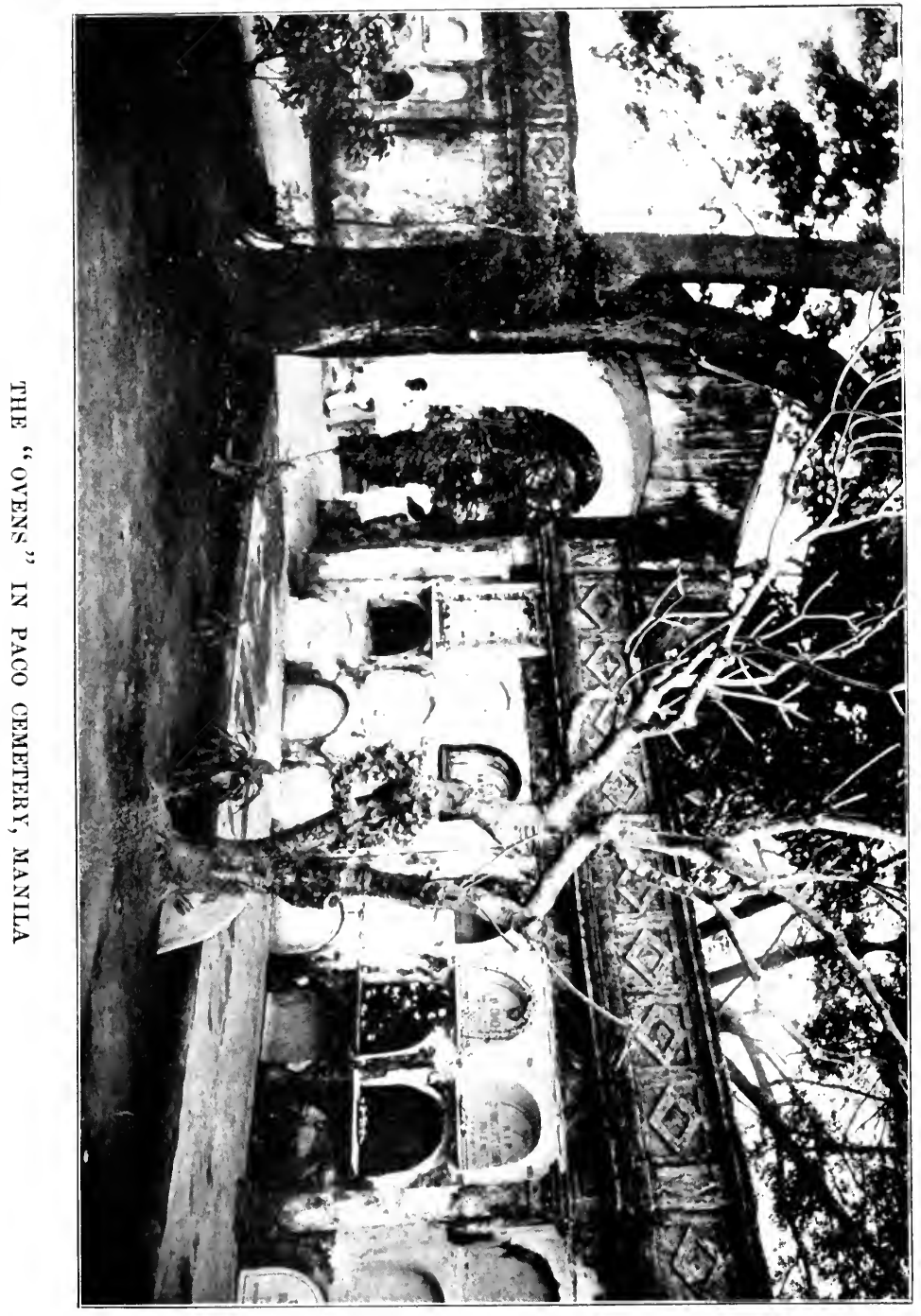



the coffeepot flew up in the air and he tumbled over. head foremost. His small boy sent up a wail of terror; and Billy Buster, the monkey, who was discussing a chicken bone, fled up to the thatch, where he remained all day until coaxed down by the tinkle of a spoon in a toddy glass. Tomas was out of breath, but not so much so that he could not ejaculate, "Sus! Maria Santisima, Señorita!" in injured tones. Ciriaco, the cook, lay down on the floor and laughed. Later I heard him and Ceferiana agreeing that I was "muy valiente."

October 25. In spite of the agua finecada and the boiled towel, Mrs. T_-'s cook has developed cholera. Though I speak of it lightly, I am truly sorry for them, for Mrs. T_ is exceedingly nervous, and they have a little child to care for.

There is a slight diminution in the death rate, and we begin to hope the worst is over.

October 28. The death rate is still decreasing. When will the rain come?

To-day I discovered that all the elaborate boilings of dish cloths and towels that have been carried out here since the epidemic began have been a mere farce. Every day for a week I went out and superintended the operation till I thought Ceferiana had mastered it. She had, indeed, caught the details, but quite missed the idea. She found the process of suspending the dish towel on a long stick till it was cool enough to wring out, a tedious one, so she set her fertile brain to work to find an expedient in the way of a bucket of cool well water, into which she dropped them. Well water! All but pure cholera! We had a hearty 


\section{IMPRESSIONS OF THE PHILIPPINES}

laugh over it at dinner to-night, though $\mathrm{Mr}$. Clooked grave. His official dignity sits heavily upon him.

Tomas dodges me when he passes. I find it impossible to restore his confidence.

November 2. The rains have come, and whether they have anything to do with it or not, the epidemic is subsiding. Two days ago, when the first shower broke after an inconceivably sultry morning, the bearers were passing with a couple of cholera patients on stretchers. They were at first minded to set them down in the rain, but thought better of it, and carried them into my lower hall. The shower lasted only a few minutes, and then they went on their way, and Ciriaco and I descended and sprinkled the floor all over with chloride of lime. While they were there, I was nervously dreading the sounds of the great suffering which accompanies cholera. But the patients were very quiet.

To-night at dinner Mr. C- tasted his coffee and looked suspicious. In my capacity of boarding-house keeper, I was instantly alarmed and tasted mine. It seemed to have been made with agua finecada. Miss $\mathrm{P}$ __ said plaintively that she had as lief die of cholera as of carbolic acid poison. Neither Ciriaco nor Ceferiana could explain. They conceded that the agua finecada was there, but could not say how. They were not much concerned, and seemed to regard it as a pleasing sleight-of-hand performance on their part.

November 5. Only eighteen deaths to-day! If the decrease continue steady, we shall open school in a 
few days. It will be a relief after the long tension of these two months - for it was a tension in spite of our refusal to discuss its more serious aspects. We have taken all legitimate precautions, and laughed at each other's oddities, knowing that it is better to laugh than to cry. But had sickness come to any of us as in the case of poor M-, everybody stood ready to chance all things to aid. But we come out unscathed with the exception of that one poor fellow.

November 14. School will begin to-morrow! Have had to discharge Tomas. He went to Baliwagan, a barrio where the cholera is still raging, last night, and Mr. S_ was properly incensed. As a parting benediction, Tomas stole a lamp of mine, but I have n't the energy to ge after him. Besides, I have a guilty conscience, and if Tomas feels our account is square, I am willing to accept his terms.

November 15. Began work again to-day. The school is much fallen off. Many pupils are dead, and the rest have lost relatives. It is a gloomy school, but the worst is over. 


\section{CHAPTER EIGHTEEN}

THE ARISTOCRACY, THE POOR, AND AMERICAN WOMEN

Aristocracy and "Caciquism" in the Philippines - Poverty of the Filipino Poor - Happiness in Spite of Poverty Virtual Slavery of the Rustics - Their Loyalty to their Employers - Wages in Manila and in the Provinces - Many Resources possessed by the UpPer Classes - Chaffering for all Kinds of íroduce-Happiness within the Reach of AMERICAN Women if EMPLOYed American Women Safe in the Philippines - After a Visit to America I AM GLAD to REturn to the Islands.

70 an American of analytical tendencies a few years in the Philippines present not only an

1 interesting study of Filipino life, but a novel consciousness of our own. The affairs of these people are so simple where ours are complex, so complex where ours are simple, that one's angle of view is considerably enlarged.

The general construction of society is medixval and aristocratic. The aristocracy, with the exception of a few wealthy brewers and cigar manufacturers of Manila, is a land-holding one. There is practically no bourgeoisie - no commercial class - between the rich and the poor. In Manila and all the large coast towns trade is largely in the hands of foreigners, chiefly Chinese, some few of whom have kecome converted to the Catholic faith, and establishe' themselves per- 
manently in the country; all of whom have found Filipino helpmates, either with or without the sanction of the Church, and have added their contingent of halfbreeds, or mestizos, to the population.

The land-owning aristocracy, though it must have been in possession of its advantages for several generations, seems deficient in jealous exclusiveness on the score of birth. I do not remember to have heard once here the expression "of good family," as we hear it in America, and especially in the South. But I have heard "He is a rich man" so used as to indicate that this good fortune carried with it unquestioned social prerogative. Yet there must be some clannishness based upon birth, for your true Filipino never repudiates his poor relations or apologizes for them. At every social function there is a crowd of them in all stages of modest apparel, and with manners born of social obscurity, asserting their right to be considered among the elect. I am inclined to think that Filipinos concern themselves with the present rather than the past, and that the parvenu finds it even easier to win his way with them than with us. Even under Spanish rule poor men had a chance, and sometimes rose to the top. I remember the case, in particular, of one family which claimed and held social leadership in Capiz. Its head was a long-headed, cautious, shrewd old fellow, with so many Yankee traits that I sometimes almost forgot, and addressed him in English. My landlady, who was an heiress in her own right, and the last of a family of former repute, told me that the old financier came to Capiz "poor as wood." She 


\section{IMPRESSIONS OF THE PHILIPPINES}

did not use that homely simile, however, but the typical Filipino statement that his pantaloons were torn. She took me behind a door to tell me, and imparted the information in a whisper, as if she were afraid of condign punishment if overheard.

"Money talks" in the Philippines just as blatantly as it does in the United States. In addition to the social halo imparted by its possession, there is a condition grown out of it, known locally as "caciquism." Caciquism is the social and political prestige exercised by a local man or family. There are examples in America, where every village owns its leading citizen's and its leading citizen's wife's influence. Booth Tarkington has pictured an American cacique in "The Conquest of Canaan." Judge Pike is a cacique. His power, however, is vested in his capacity to deceive his fellowmen, in the American's natural love for what he regards as an eminent personality, and his clinging to an ideal.

A Filipino cacique is quite a different being. $\mathrm{He}$ owes his prestige to fear - material fear of the consequences which his wealth and power can bring down on those that cross him. He does not have to play a hypocritical role. He need neither assume to be, nor be, a saint in his private or public life. He must simply be in control of enough resources to attach to him a large body of relatives and friends whose financial interests are tied up with his. Under the Spanish regime he had to stand in by bribery with the local governor. Under the American regime, with its illusions of democracy, he simply points to his clientele 
and puts forward the plea that he is the natural voice of the people. The American Government, helpless in its great ignorance of people, language, and customs, is eager to find the people's voice, and probably takes him at his word. Fortified by Government backing, he starts in to run his province independently of law or justice, and succeeds in doing so. There are no newspapers, there is no real knowledge among the people of what popular rights consist in, and no idea with which to combat his usurpations. The men whom he squeezes howl, but not over the principle. They simply wait the day of revolution. Even where there is a real public sentiment which condemns the tyrant, it is half the time afraid to assert itself, for the tyrant's first defence is that they oppose him because he is a friend of the American Government. Local justice of the peace courts are simply farcical, and most of the cacique's violations of right keep him clear at least of the courts of first instance, where the judiciary, Filipino or American, is reliable. Thus our Government, in its first attempts to introduce democratic institutions, finds itself struggling with the very worst evil of democracy long before it can make the virtues apparent.

The poor people among the Filipinos live in a poverty, a misery, and a happiness inconceivable to our people who have not seen it. Their poverty is real-not only relative. Their houses are barely a covering from rain or sun. A single rude bamboo bedstead and a stool or two constitute their furniture. There is an earthen water jar, another earthen pot for cooking 
rice, a bolo for cutting, one or two wooden spoons, and a cup made of cocoanut shells. The stove consists of three stones laid under the house, or back of it, where a rice-pot may be balanced over the fire laid between. There are no tables, no linen, no dishes, no towels. The family eat with their fingers while sitting about on the ground with some broken banana leaves for plates. Coffee, tea, and chocolate are unknown luxuries to them. Fish and rice, with lumps of salt and sometimes a bit of fruit, constitute their only diet. In the babies this mass of undigested half-cooked rice remains in the abdomen and produces what is called "rice belly." In the adults it brings beriberi, from which they die quickly. They suffer from boils and impure blood and many skin diseases. Consumption is rife, and rheumatism attacks old and young alike. They are tormented by gnats and mosquitoes, and frequently to rid themselves of the pests build fires under the house and sleep away the hot tropical night in the smoke. While the upper classes are abstemious, the lower orders drink much of the native vino, which is made from the sap of cocoanut and nipa trees, and the men are often brutal to women and children.

I think the most hopeful person must admit that this is an enumeration of real and not fancied evils, that the old saw about happiness and prosperity being relative terms is not applicable. The Filipino laborer is still far below even the lowest step of the relative degree of prosperity and happiness. Yet in spite of these ills he is happy because he has not developed enough to achieve either self-pity or self-analysis. He 
bears his pain, when it comes, as a dumb animal does, and forgets it as quickly when it goes. When the hour of death descends, he meets it stoically, partly because physical pain dulls his senses, partly because the instinct of fatalism is there in spite of his Catholicism.

Of course this poverty-stricken condition is largely his own fault. He has apparently an ineradicable repugnance to continued labor. He does not look forward to the future. Fathers and mothers will sit the whole day playing the guitar and singing or talking, after the fashion of the country, with not a bite of food in the house. When their own desires begin to reinforce the clamors of the children, they will start out at the eleventh hour to find an errand or an odd bit of work. There may be a single squash on the roof vine waiting to be plucked and to yield its few centavos, or they can go out to the beach and dig a few cents' worth of clams.

The more intelligent of the laboring class attach themselves as cliente to the rich land-holding families. They are by no means slaves in law, but they are in fact; and they like it. The men are agricultural laborers; the women, seamstresses, house servants, and wet nurses, and they also do the beautiful embroideries, the hat-plaiting, the weaving of piña, sinamay, and jusi, and the other local industries which are carried on by the upper class. The poor themselves have nothing to do with commerce; that is in the hands of the well-to-do.

As the children of the clientèle grow up, they are 


\section{IMPRESSIONS OF THE PHILIPPINES}

scattered out among the different branches of the ruling family as maids and valets. In a well-to-do Filipino. family of ten or twelve children, there will be a child servant for every child in the house. The little servants are ill-fed creatures (for the Filipinos themselves are merciless in what they exact and parsimonious in what they give), trained at seven or eight years of age to look after the room, the clothing, and to be at the beck and call of another child, usually a little older, but ofttimes younger than themselves. They go to school with their little masters and mistresses, carry their books, and play with them. For this they receive the scantiest dole of food on which they can live, a few cast-off garments, and a stipend of a medio-peso (twenty-five cents U. S. currency) per annum, which their parents collect and spend. Parents and child are satisfied, because, little as they get, it is eertain. Parents especially are satisfied, because thus do they evade the duties and responsibilities of parenthood.

It was at first a source of wonder to me how the rich man came out even on his scores of retainers, owing to their idleness and the demands for fiestas which he is compelled to grant. But he does succeed in getting enough out of them to pay for the unhulled rice he gives them, and he more than evens up on the children. If ever there was a land where legislation on the subject of child labor is needed, it is here. Children are overworked from infancy. They do much of the work of the Islands, and the last drop of energy and vitality is gone before they reach manhood or womanhood. 
Indeed, the first privilege of manhood to them is to quit work.

The feeling between these poor Filipinos and their so-called employers is just what the feeling used to be between Southerners and their negroes. The lower-class man is proud of his connection with the great family. He guards its secrets and is loyal to it. He will fight for it, if ordered, and desist when ordered.

The second house I lived in in Capiz was smaller than the first, and had on the lower floor a Filipino family in one room. I demanded that they be ejected if I rented the house, but the owner begged me to reconsider. They were, she said, old-time servants of hers to whom she felt it her duty to give shelter. They had always looked after her house and would look after me.

I yielded to her insistence, but doubtingly. In six weeks I was perfectly convinced of her wisdom and my foolishness. Did it rain, Basilio came flying up to see if the roof leaked. If a window stuck and would not slide, I called Basilio. For the modest reward of two pesos a month (one dollar gold) he skated my floors till they shone like mirrors. He ran errands for a penny or two. His wife would embroider for me, or wash a garment if I needed it in a hurry. If I had an errand which took me out nights, Basilio lit up an old lantern, unsolicited, and went ahead with the light and a bolo. If a heavy rain came up when I was at school, he appeared with my mackintosh and rubbers. And while a great many small coins went from me to him, I could never see that the pay was proportional to 


\section{IMPRESSIONS OF THE PHILIPPINES}

his care. Yet there was no difficulty in comprehending it. Pilar (my landlady) had told him to take care of me, and he was obeying orders. If she had told him to come up and bolo me as I slept, he would have done it unhesitatingly.

The result of American occupation has been a rise in the price of agricultural labor, and in the city of Manila in all labor. But in the provinces the needlewoman, the weaver, and the house servant work still for inconceivably small prices, while there has been a decided rise in the price of local manufactures. Jusi, which cost three dollars gold a pattern in 1901, now costs six and nine dollars. Exquisite embroiderers on piña, which is thinner than bolting cloth, have quadrupled their prices, but the provincial women servants, who weave the jusi and do the embroidering, still work for a few cents a day and two scanty meals.

When I arrived here a seamstress worked nine hours a day for twenty cents gold and her dinner. Now in Manila a seamstress working for Americans receives fifty cents gold and sometimes seventy-five cents and her dinner, though the Spanish, Filipinos, and Chinese pay less. In the province of Capiz twelve and a half cents gold per day for a seamstress is the recognized price for an American to pay - natives get one for less. A provincial Filipino pays his coachman two and a half dollars gold a month, and a cook one dollar and a half. An American for the same labor must pay from four to eight dollars for the cook and three to six dollars for the coachman. As before stated, the 
subordinate servants in a Filipino house cost next to nothing, because of the utilization of child labor.

A provincial Filipino can support quite an establishment, and keep a carriage on an income of forty dollars gold a month where to an American it would cost sixty or eighty dollars. This is due partly to our own consumption of high-priced tinned foods, partly to the better price paid for labor, but chiefly to our desire to feed our servants into good healthy condition. We not only see that they have more food, but we look more closely to its variety and nutritious qualities. We employ adults and demand more labor, because our housekeeping is more complex than Filipino housekeeping, and we expect to employ fewer servants than Filipinos do.

The Filipinos, the Spanish, and even the English who are settled here cling to mediæval European ideas in the matter of service. If they have any snobbish weakness for display, it is in the number of retainers they can muster. Just as in our country rural prosperity is evinced by the upkeep of fences and buildings, the spic and span new paint, and the garish furnishings, here it is written in the number of servants and hangers-on. The great foreign trading firms like to boast of the tremendous length of their pay rolls. They would rather employ four hundred underworked mediocrities at twenty pesos a month than half a hundred abilities at four times that amount. The land-holders like to think of the mouths they are responsible for feeding so very poorly, and the busy housewife jingles her keys from weaving-room to 
embroidery frame, from the little tienda on the ground floor, where she sells vino, cigars, and betel-nut, to the extemporized bakery in the kitchen, where they are making rice cakes and taffy candy, which an old woman will presently hawk about the streets for her.

One of the curious things here is the multiplicity of resource which the rich classes possess. A rich landholder will have his rice fields, sugar mill, vino factory, and cocoanut and hemp plantations. He will own a fish corral or two, and be one of the backers of a deepsea fishing outfit. He speculates a little in rice, and he may have some interest in pearl fisheries. On a bit of land not good for much else he has the palm tree, which yields buri for making mats and sugar bags. His wife has a little shop, keeps several weavers at work, and an embroidery woman or two. If she goes on a visit to Manila, the day after her return her servants are abroad, hawking novelties in the way of fans, knick-knacks, bits of lace, combs, and other things which she has picked up to earn an honest penny. If a steamer drops in with a cargo of Batangas oranges, she invests twenty or thirty pesos, and has her servants about carrying the trays of fruit for sale. According to her lights, which are not hygienic, she is a good housekeeper and a genuine helpmeet. She keeps every ounce of food under lock and key, and measures each crumb that is used in cooking. She keeps the housekeeping accounts, handles the money, never pries into her husband's affairs, bears him a child every year, and is content, in return for all this devotion, with an ample supply of pretty clothes and her jewels. 
She herself does not work, busy as she is, and it speaks well for the faith and honor of the Filipino people that she can secure labor in plenty to do all these things for her, to handle moneys and give a faithful account of them. It is pitiful to see how little the Filipino laboring class can do for itself, how dependent it is upon the head of its superiors, and how content it is to go on piling up wealth for them on a mere starvation dole.

As before said, the laboring man who attaches himself to a great family does so because it gives him security. He is nearly always in debt to it, but if he is sick and unable to work he knows his rice will come in just the same. Under the old Spanish system, a servant in debt could not quit his employer's service till the debt was paid. The object of an employer was to get a man in debt and keep him so, in which case he was actually, although not nominally, asslave. While this law is no longer in force, probably not ten per cent of the laboring population realize it. They know that an American cannot hold them in his employ against their will, but they do not know that this is true of Filipinos and Spaniards. Nor is the upper class anxious to have them informed. The poor frequently offer their children or their younger brothers and sisters to work out their debts.

Children are sold here also. Twice in my first year at Capiz, I refused to buy small children who were offered for sale by their parents lest the worse evil of starvation should befall them; and once, on my going into a friend's house, she showed me a child of three 


\section{IMPRESSIONS OF THE PHILIPPINES}

or four years that she had bought for five pesos. She remarked that it was a pity to let the child starve, and that in a year or two its labor would more than pay for its keep.

Filipinos who have capital enough all keep one or more pigs. These are yard scavengers, and, as sanitary measures are little observed by this race, have access to filth that makes the thought of eating their flesh exceedingly repulsive. When the owners are ready to kill, however, the pig is brought upstairs into the kitchen, where it lives luxuriously on boiled rice, is bathed once a day, and prepared for slaughter like a sacrificial victim. If you are personally acquainted with a pig of this sort and know the day set for his decease, you may send your servant out to buy fresh pork; otherwise you had better stick to chicken and fish.

Before the Insurrection, when the rinderpest had not yet destroyed the herds, beef cattle were plenty, and meat was cheap enough for even the poorest to enjoy. A live goat, full grown, was not worth more than a peso (fifty cents gold). Now there are practically no beef cattle at all, so the only meat available is goats' flesh, which is sold at from twenty to sixty cents a pound (ten to thirty cents gold). Americans living in the provinces rely largely upon chicken, though in the coast towns there is always plenty of delicious fish. There are also oysters (not very good), clams, crabs, shrimps, and crayfish.

One of the most irritating features of housekeeping here is the lack of any fixed value, especially for market produce. There are no grocery stores, every article 
must be chaffered over, and is valued according to the owner's pressing needs, his antipathy for Americans, or his determination to get everything he can.

You may be driving in the country and see a flock of chickens feeding under or near a house. You ask the price. The owner has just dined. There is still enough palay (unhulled rice) to furnish the evening meal. He has no pressing need of money, and he does n't want to disturb himself to run down chickens. His fowls simply soar as to price. They are worth anywhere from seventy-five cents to a dollar apiece. The current price of chickens varies according to size and season from twenty to fifty cents. You may offer the latter price and be refused. The next day the very same man may appear at your home, offering for twenty or thirty cents the fowls for which the day before he refused fifty.

Except in the cold storage and the Chino grocery shops of Manila, nothing can be bought without chaffering. The Filipinos love this; they realize that we are impatient and seldom can hold out long at it, and in many cases they overcharge us from sheer race hatred. Also they have the idea, as they would express it, that our money is two times as much as theirs, and that therefore we should pay two prices. Often they put a price from sheer caprice or effrontery and hang to it from obstinacy. In the same market I have found mangoes of the same quality ranging all the way from thirty cents to a dollar and fifty cents a dozen.

In the provinces market produce is very limited. In fresh foods there is nothing but sweet potatoes, several 


\section{IMPRESSIONS OF THE PHILIPPINES}

varieties of squash, a kind of string bean, lima beans, lettuce, radishes, cucumbers (in season), spinach, and field corn. Potatoes and onions can be procured only from Manila, bought by the crate. If there be no local commissary, tinned foods must be sent in bulk from Manila. The housekeeper's task is no easy one, and the lack of fresh beef, ice, fresh butter, and milk wears hard on a dainty appetite. The Philippinés are no place for women or men who cannot thrive and be happy on plain food, plenty of work, and isolation. Nor is there any sadder lot than that of the American married woman in the provinces who is unemployed. Her housekeeping takes very little time, for the cheapness of native servants obviates the necessity of all labor but that of supervision. There is nowhere to go, nothing to do, nothing to read, nothing to talk about. She has nothing to do but to lie in a steamer chair and to think of home. Most women break down under it very quickly; they lose appetite and flesh and grow fretful or melancholy. But to a woman who loves her home and is employed, provincial life here is a boon. Remember that for an expenditure of forty or fifty dollars a month the single woman can maintain an establishment of her own - a genuine home - where after a day's toil she can find order and peace and idleness awaiting her. Filipino servants are not ideal, but any woman with a capacity for organization can soon train them into keeping her house in the outward semblance at least of order and cleanliness. She had better investigate it pretty closely on Saturdays and Sundays; if she does so, she can leave it to run itself 
very well during the five days of her labor. And what a joy it is - I speak in the bitter remembrance of a long line of hotels and boarding-houses - to go back to one's home after a day's labor instead of to a hall bedroom; to sit at one's own well-ordered if simple table, and escape the chatter of twenty or thirty people who have no reason for association except their economic necessities!

In the six years I have lived in these Islands, I have never heard of indignity or disrespect shown to American women. ${ }^{1}$ They are perfectly safe, and if they choose to exercise any common sense, need not be nervous. Housebreaking outside of Manila is unknown. I myself lived for four years in a provincial town, the greater part of the time quite removed from the neighborhood of other Americans, with only two little girls in the house with me. I remember one evening having a couple of civil engineers, who had been fellow passengers on the transport and were temporarily in town, to dinner. When they were ready to leave, at half-past ten, the little girls had both gone to sleep, so I went downstairs to let them out and bar the door after them. One burst out laughing and remarked that my bolting the door was a formality, and that I must have confidence in the honesty of the natives. The door was of bamboo, tied on with strips of rattan in place of hinges, which any one could have cut with a knife. I admitted

1 Since the writing of the above sentence, one American woman has been murdered in Batangas, one young girl violated in Manila, and knowledge has come to the writer of three cases of attempted assault on American women, which were kept out of the newspapers. 


\section{IMPRESSIONS OF THE PHILIPPINES}

that the man was right, but the closed door was the symbol that my house was my castle, and I had no fear of Filipino thieves. The only time I was ever really afraid was when there were two or three disreputable Americans in town.

The two girls from Radcliffe were in a town in Negros where there was no other American, man or woman, and held their position for over a year; nor were they once affrighted in all that time.

After five years of this peace and security in the "wilds," I went back to the United States and met the pitying ejaculations of the community on my exile. Well, there was a difference. I noted it first on the dining-car of the Canadian-Pacific Railroad, where one's plate was surrounded by a host of little dishes, where the clatter of service was deafening (so different from the noiselessness of the Oriental), and the gentleman who filled my water glass held it about three feet from the water bottle, and manipulated both in sympathetic curves which expressed his entire mastery of the art. I found it again on the Northwestern, where the colored porter, observing some Chinese coins in my purse when I tipped him, said, "Le's see," with a confidence born of democracy, and sat down on the arm of the Pullman seat to get a better view of them.

But it was in Chicago - the busy, noisy, dusty, hustling Chicago - that all the joys of civilization fell on me at once. It seemed to be in a state of siege with house thieves, assassins, and "hold-ups." There had been several murders of women, so revolting that the newspapers would not print the details. I found my broth- 
er's flat equipped with special bolts on all outside doors, so that they could be opened for an inch or two without giving anybody an opportunity to push in. Once when a police officer called at the door to ask for subscriptions for the sufferers of the San Francisco disaster, I locked him out on the back porch while I did some telephoning to see if it was all right. Women were afraid to be on the streets in the early dusk. Extra policemen had been sworn in, preachers had delivered sermons on the frightful condition of the city.

At night I locked my bedroom door, and dreamed of masked burglars standing over me threatening with drawn revolver. For the thirty days I remained there, I knew more of nervousness and terror than the whole time I spent in the Philippines, and I came back to resume the old life where there is security in all things, barring a very remote insurrection and the possibility of hearing the roar of Japanese guns some fine morning. And through and through a grateful system I felt the lifting of the tremendous pressure, the agonizing strain, competition, and tumult of American life. Thank Heaven! there is still a mañana country - a fair, sunny land, where rapid transportation and sky-scrapers do not exist. 


\section{CHAPTER NINETEEN}

\section{WEDDINGS IN TOWN AND COUNTRY}

Filipino Brides, their Weddings and Wedding Suppers A River Trip to a Rural Wedding - Our late Arrival delays the Ceremony until Next Morning - The Ball - We tramp across the Fields to the Church - After the Marriage, Feasting and Dancing.

7 HE composure with which a Filipino girl enters matrimony is astounding. There are no tears,

1 no self-conscious blushes, none of the charming shyness that encompasses an American girl as a garment. It is a contradictory state of affairs, I must admit, for this same American girl is a self-reliant creature, accustomed to the widest range of action and liberty, while the matter-of-fact, self-possessed Filipina has been reared to find it impossible to step across the street without attendance. But the free, liberty-loving American yields shyly to her captor, while the sedateness of the prospective matron has already taken possession of the dusky sister.

Filipino marriages, among the upper class, are accompanied by receptions and feasts like our own, but differ greatly in the comparatively insignificant part played by the contracting parties. Whereas, in an American wedding, the whole object of calling all these people together seems to be a desire to silhouette the 
bride and groom against the festive background, one comes away from a Filipino celebration with a feeling that an excuse was needed for assembling a multitude and permitting them to enjoy themselves, and that the bridal pair unselfishly lent themselves to the occasion.

Most weddings take place about half-past six or seven in the evening; and immediately after the religious ceremony in the church, all the invited guests adjourn to the home of a relative (usually, but not necessarily, the nearest kinsman of the bride), where supper is served and is followed by a ball.

On these occasions, except for the candles on the altar, the church is unlighted, and in its cavernous darkness the footfalls of a gathering crowd ring on the stone floor, and the hum of voices rolls up into the arching gloom of the roof.

There are no pews, but two rows of benches, facing each other, up the middle length of the edifice, offer seats to the upper-class people, who seem chiefly interested in preserving the spotlessness of their gala attire. No attempt at exclusiveness is made, and a horde of babbling, gesticulating, lower-class natives surges to and fro at the rear, awaiting the bride.

Presently, to the clangor of half a dozen huge bells, she sweeps in, accompanied by her madrina, or chief witness. They take station at the back between the baptismal fonts and just in front of the overhanging choir gallery. Instantly they are hemmed in, mobbed, by that swarm of pobres, some speculating on the motive of the match and its probable outcome. Meanwhile the bridegroom is smoking a cigarette at one side, and 
chatting with a group of bachelor friends who are faithful to the last.

Just as one begins to wonder how much longer these unfortunate women can endure the position, the barefooted acolytes shuffle in, bearing six-foot silver candlesticks, and preceding the padre, who is carrying his illumination with him - or rather, having it carried in front of him. The bridegroom throws away his cigarette, and shouldering his way through the press, takes his position at the side of the bride. The mob closes in again, not infrequently incommoding the padre, who is peering at his half-lighted missal. The aristocrats on the benches pay no attention and continue to guard their ropa and converse on chance topics.

To one standing on the edge of that wriggling throng with the yellow flare just lighting the impassive countenances of its chief personages, and hearing a low monotone, broken only by the clink of metal as gold pieces fall into the plate, it is difficult to believe that this is a wedding, just like those pictured and tableau effects that one is treated to at home.

At last the voice stops, the mob and the smoky candles surge forward to the altar, where the benediction is said. Another impeded progress to the rear (everybody gets up without waiting for the bride and bridegroom to pass), the sorely tried couple step into a waiting victoria, and we troop after them, getting our felicitations ready.

On arriving at the house we are received by the groom and some female relative of his, or, perchance, the bride's papa. No opportunity of formally congratulating the 


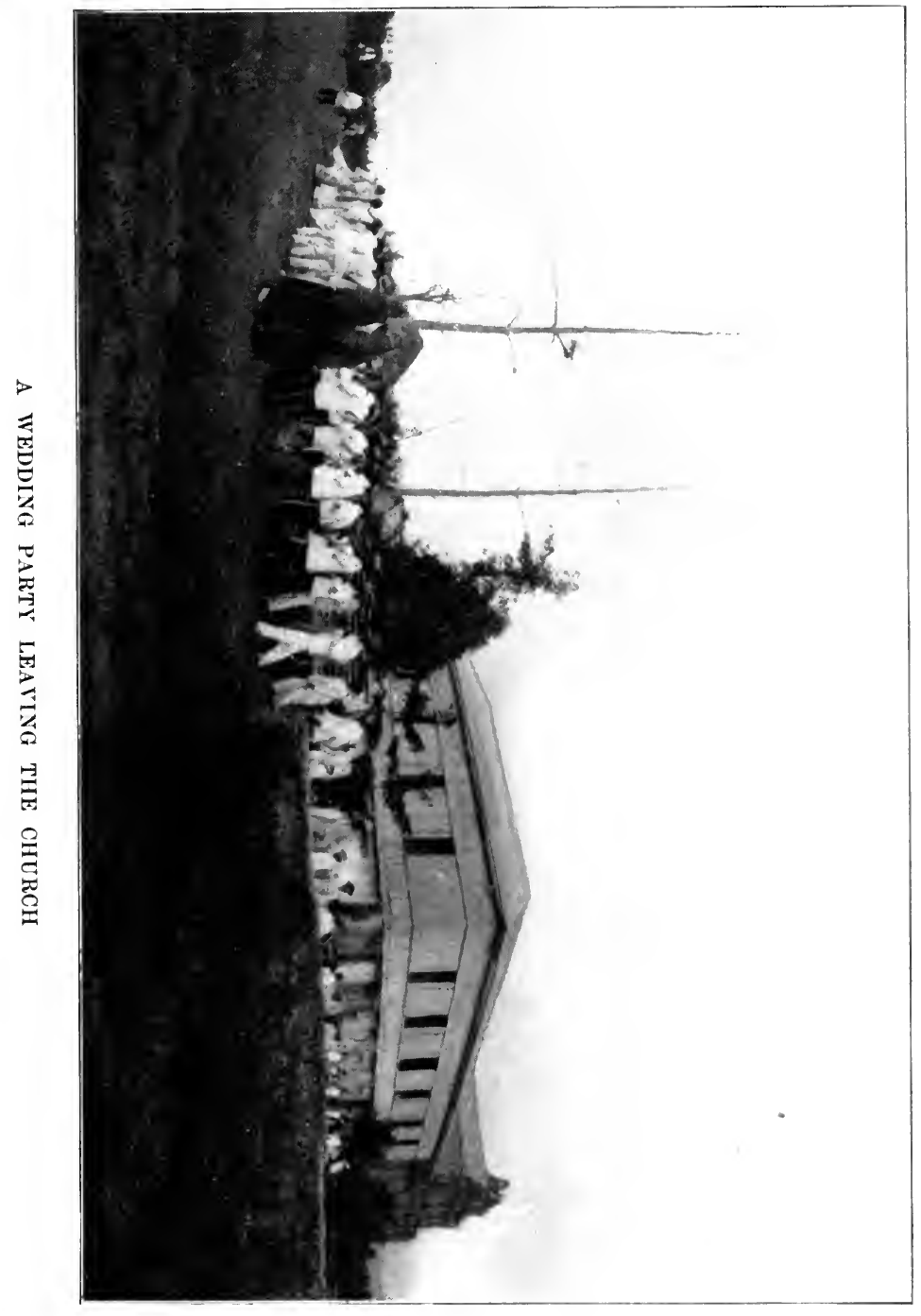





\section{WEDDINGS IN TOWN AND COUNTRY 253}

young couple is offered. The bride retires into an inner room, where she removes her veil, and receives such of her lady friends as desire to kiss her on both cheeks. But by and by she comes out, self-possessed and unsmiling, to distribute the fragments of her artificial orange blossom wreath to her aspiring girl friends. This is a parallel to the distribution of wedding cake, which the American girl puts under her pillow and dreams upon.

By this time the orchestra has arrived and is playing triumphantly under the windows. Though engaged beforehand, it always accomplishes its appearance with a casual and unpremeditated air. The musicians are then (per contract) invited to enter, and strike up a rigadoon. Generally, but not always, the most important man present invites the bride for this dance. But I have known brides to sit it out, for lack of a partner. The bridegroom chooseth as he listeth; when American women are present, the fathers of the bride and groom usually request the honor of leading them out.

After this first dance supper is served. If an important native official be present, it is a point of etiquette that he take the bride. Only a few men of high rank sit at the first table, which is given over to women. The service is not left to servants, but all male relatives of the family vie with each other in anticipating the wants of the guests.

It is a feast of solid and satisfying excellence. It begins usually with vermicelli soup (made from a lard stock) which is more than likely to have been dished a 


\section{IMPRESSIONS OF THE PHILIPPINES}

half-hour and to be stone cold. But Filipinos are not critical in this regard; and Americans, in view of all that is coming, may dispense with this one dish.

Then follow meats innumerable, each with its own garnish, but without separate vegetables. There is goat's flesh stewed with garbanzas, onions, potatoes, and peppers; chicken minced with garlic, and green peas; chicken boned and made to look and taste like breaded cutlet; boiled ham; a fat capon, boned, stuffed, and seasoned with garlic, his erstwhile proud head rolling in scarified humility; breaded pork chops; roast pork, with unlimited crackling; cold turkey; baked duck, and several kinds of fish.

There are no salads, but plenty of relishes, including the canned red peppers of Spain; olives, pickles, cheese, and green mango pickles. At intervals along the table are alluring glass dishes, filled with crystallized fruits.

After this come the sweets. There is no cake, as we know it, but meringues (French kisses), baked custard coated with caramel sauce, which they call flaon; a kind of cocoanut macaroon, the little gelatinous seeds of the nipa palm, boiled in sugar syrup, and half a dozen kinds of preserves and candied fruits. Tinto accompanies the supper, and possibly champagne.

As two or three hundred people are served on such an occasion, the intermission for supper is a long one, and dancing is not resumed till half-past nine or ten o'clock. It may then continue till midnight or dawn, just as the actions of a few important guests may determine. Filipinos are very quick to follow a lead; and if, owing perhaps to a concurrence of events which 
may be perfectly foreign to the occasion, a number of prominent people leave early, the rest soon take flight.

In one of the later years of my stay my good fortune led me to witness a wedding of another type, which differed from the class I have described as the simple rural gathering at home differs from the exotic atmosphere of a fashionable reception. It was just after my return from vacation that one morning a group of my pupils burst in, accompanying a middle-aged Filipina who hesitatingly made known her errand. Her niece, who lived some five or six miles up the river, was to be married that night, and a large number of people from town were going up. Could I accompany them, and would $I$ act as one of the three madrinas for the occasion? As the bride was of an insurrecto family, whose name was familiar through bygone military acquaintances, I snapped at an opportunity to view the insurrecto upon his own (pacified) hearth, and after consuming a hasty lunch and packing a valise, I set out for the river bank where we were to rendezvous.

Our craft, a catamaran made by securing three barotos side by side and flooring them with bamboo, was the centre of great public excitement. It had a walk outrigged at each side for the men who were to punt, or pole us up the river. It was roofed with a framework of bamboo, which was covered with palm - leaves and wreathed in bonoe-bonoe vines, and from this green bower were suspended the fruits of the season. - bananas, the scarlet sagin-sagin, and even succulent ears of sweet corn. 
Cane stools were provided for a few, but many of the young people sat flat on the floor. When we were embarked, to the number of about forty, the barotos were so deep in the water that the swirling current was within an inch of their gunwales. A tilt to one side or a wave in the river would have sunk us.

The baggage and a few supernumerary young men and a mandolin orchestra were loaded into an enormous baroto, and ten sturdy brown backs bent forward as the boatmen pushed with all their strength against the great bamboo poles, which looked as if they would snap under the strain.

The river was swollen with three days' tropical downpour and running out resistlessly in the teeth of a high tide. As we slipped out of the shallow water at the bank, the current caught us and hurled us fifty feet down stream. The baroto left apparently for the port, which was four miles away. Our valiant punters were useless against the river; but amid a hubbub in which every man, woman, and babe aboard, except one American man and myself, appeared to be giving orders, we got back to the bank and shipped an additional crew. This consumed time, because the spectators, who had seen what work it was going to be, were coy of enlisting. But at last we got away, eight men to a side, and the water perceptibly nearer the gunwales, and with infinite labor we succeeded in poling around a bend and leaving the town behind us.

But there we stuck again in a swift reach, and there were time and opportunity to marvel at the impenetraable green and silence of the nipa swamps. The banks 
- or rather limits of the current - were thickets of water grass six feet high, its roots sunk in ooze. Here and there a rise of ground betrayed itself in a few cocoanuts, the ragged fans of tall bouri palms, or a plume-like clump of bamboo and the hospitable shade of a magnificent mango tree.

The atmosphere was close and muggy, and now and then a shower pattered down on us. Suddenly, through the strange desolation of this alien landscape, the familiar thump of guitars and mandolins assailed the stillness. The music carried me back to half-forgotten experiences - red sunsets between the cathedral bluffs of the Mississippi, and sad-eyed negroes twanging the strings on the forward deck of a nosing steamboat; crisp July afternoons on the Straits of Mackinac when the wind swept in from froth-capped blue Huron, and the little excursion steamer from St. Ignace rollicked her way homeward to the cottage-crowned heights of the island.

I shut my eyes and tried to "make believe" that they would open on far-off, familiar scenes. Nothing could have been more weird and incongruous than the American air with this alien soil and people. It was "Hiawatha," and to the inspiring strains of "Let the women do the work, let the men take it easy," our forgotten baroto swept into sight in the easy water under the opposite bank. We made a herculean effort, inspired by envy, and got away. Space forbids me to enumerate the hairbreadth escapes of that journey. We put men ashore when the banks permitted and were towed like a canal boat. Once we were swept 
into mid-stream, where the poles were useless on account of the great depth, and had to drift back till the water shoaled again. In late afternoon we took on a supply of sugar cane, and chewed affably all the rest of the way.

At first I had been nervous, but my native friends were quite unconcerned. So remembering that Heaven protects the insane and the imbecile, and regarding them as the former and myself as the latter, I ceased to speculate on the probabilities of another incarnation.

We consumed six hours in a journey normally accomplished in two, and night overtook us in a labyrinth of water lanes above whose forested swamps the outlines of a stern old church were magnified in the gloom. One by one the stars sprang mysteriously into view in the soft void overhead, and somehow - marvellously - we found our destination. A group of friends and servants flared their torches on the bank, and we dragged our stiffened limbs to them. It was too dark to see where we were going, until we stumbled almost into a lighted doorway and found the company awaiting us. Owing to the delay in our arrival, the wedding was deferred till the next morning, but the ball was about to open.

Food was given us, and after a freshening up and a change of raiment we joined the reunion, which was in full swing. The prospective husband and wife were enjoying their usual state of effacement, but I discovered them finally. I talked with the insurrecto and found him a man of ability.

I left the ball, exhausted, at one o'clock, but those 
indefatigable people kept it up all night. I awoke at dawn to find the floor occupied by about twenty yawning maidens who were merely resting, for there was no time for a nap. We dressed in the cool dawn breeze and went out in time to see the morning mists rise from a broad oval of rice and maize fields, and hang themselves in ever-changing folds on the sides of the purple mountains beyond.

But for the character of the vegetation that rimmed the arable land, and the bare green shoulders of the hills, streaked here and there with pink clayey ravines, it might have been a peaceful sunrise in middle America. The homelike atmosphere was accentuated by the roofs of a town and by a church spire, still silvered with mist, half a mile away. We tramped across the fields to our objective point. As madrina, I walked with the bride, but conversation did not thrive because she spoke little Spanish, and I less Visayan.

Carabaos sniffed at us as we passed, and people crowded their windows to look. We crossed a slough upon a bridge of quaint and ancient architecture on the thither side of which were a grassy plaza and the stern lines of the church. The wedding bells broke forth in a furious joy and flung their notes to the distant hill flanks, which in turn flung them back to the blue, sparkling sea.

The church was tiled in black and white marble, and inhabited by a lusty family of goats. Their innate perversity and an apparent curiosity led them to resent exclusion; but after a lively pursuit they were ejected, and the bride and I sat on a bench to rest. The bride- 
groom took a last smoke, and the strangers deciphered obituary notices on the mural tombstones.

The padre came along finally, smelling of a matutinal appetizer, and they distributed pillows and candles to the madrinas and padrinos. As evidence of change of heart in the late insurrecto, the pillows were some of red, some of white, and some of blue cloth.

It was over at last, when I was stiff with kneeling and had ornamented myself with much candle grease. I went up to congratulate the bride, but felt that the handshake was not coming off properly. Finally I discovered that I was resisting an effort on her part to bring my hand to her lips. So I succumbed and submitted to the distinction, and she then proceeded to salute the other madrinas.

There was nothing coy or sentimental about that bride. She needed no support, moral or other. Sweet sixteen, "plump as a partridge," she gathered up her white silk skirt with its blue ribbons and struck out for home. Her husband made no attempt to follow her. She beat us all home by a quarter of a mile. When we arrived, she had changed her gown and was supervising breakfast preparations.

I was tired, and when a native sled drawn by a carabao came along, was glad enough to seat myself on its flat bottom, together with one or two wearied maidens, and be drawn back in slow dignity. We intercepted a boy with roasting ears, and the wedding guests sat about, nibbling like rodents while we waited breakfast.

After that meal dancing began again and continued 
until dinner. Once the floor was cleared, and the bridal pair danced one waltz together. They did not glance once at each other, and seemed bored.

Dinner was another feast, and afterwards we sought our state barge and the perils of the return journey. The newly married couple came down to see us off, still bearing themselves with a preoccupied and listless air. The orchestra remained until the next day, and we threaded the water lanes in quiet, emerging at last on the full-breasted river. The home journey consumed only three hours, and was comparatively uneventful. The wife of the Presidente gathered her family about her and artlessly searched their raven pates for inhabitants which pay no taxes, and most of the young people drooped with weariness. We rounded the bend at five o'clock; and thankful I was to put foot on terra firma once more. I was tired, but glad that I had gone. 


\title{
CHAPTER TWENTY
}

\author{
SICKBEDS AND FUNERALS
}

Customs in the Treatment of the Sick - Stately Funeral Processions - The Funeral of a Poor Man - Unsociableness of the Poor - Wakes and Burial of the Rich - A "Petrified" Man.

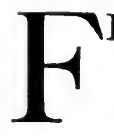

IILIPINOS are punctilious about many things concerning which we have passed the extremely punctilious stage. Some of their strictest observances are in the matters of sickness and death. The sick have what we would consider a hard time. To begin with, they are immured in rooms from which, as far as possible, all light and air are excluded. In a tropical climate, where the breeze is almost indispensable to comfort, the reader may imagine the result. Then all their relatives, near and far, flock to see them; they crowd the apartment, and insist on talking to keep the patient from becoming triste. When the sufferer finds this insupportable and gives up the struggle to live, the whole clan, out to the last connection, set about preparing their mourning.

Every woman makes a black dress, and every man ties a band of black cloth around his white coat sleeve. When there is a wake, it is noisy enough to be Irish. Our Eastern friends resemble the Irish also in their 
love of a fine funeral. To go to the last resting-place escorted by a band and with all possible ceremony seems to make even death acceptable to them.

Among the very poor this ambition is quite disproportionate to their resources. The percentage of infant mortality, owing to poor nutrition, is especially high; yet babe after babe whose mother unwittingly starved it to death is given a funeral in which the baby carriage hearse is preceded by a local band, and hired mourners stalk solemnly behind the little coffin in place of the mother, who is, in etiquette, required to remain at home.

In Manila funerals resemble our own, save that the hearse, be it white for a child or black for an adult, is drawn by stately caparisoned horses, at the bridles of which stalk men in eighteenth-century court costumes, which include huge shoe buckles, black silk stockings, and powdered wigs. The carriages flock behind with little pretence of order, and at a sharper pace than is customary with us. The populace are, however, most respectful; rich and poor alike remove their hats when the funeral cortège is passing.

In the provinces where there are no hearses, a funeral consists usually of a coffin carried on the shoulders of four men, and followed by a straggling concourse of mourners. If the corpse be that of a child, it not infrequently lies, gorgeously dressed, upon the blue-and-pink-beribboned cushions of a fourwheeled baby carriage. New-born babes are buried in tiny coffins covered with pink or blue cambric.

The Filipinos say that when a child dies its pure 


\section{IMPRESSIONS OF THE PHILIPPINES}

little soul goes straight to gloria, wherefore it is much to be congratulated on leaving this abode of sorrow for one of unending happiness, and only gay music is used at the funeral. The local bands play solely by ear, and make the most of whatever music they hear sung or whistled on the streets, with the result that strangely inappropriate selections are used on these occasions. At the first child's funeral I ever saw, the band was playing "Hot Time," and a friend to whom I related this fact, declared that at the first one he ever saw they were playing, "I don't care if you never come back." This sounds too fortuitously happy to be true, but it is quite within the possible.

When I had lived in Capiz a year or two, my washerman, or lavandero, died, and his widow, pointing to a numerous progeny, besought for an advance of five pesos for necessary funeral expenses. She wanted ten, but I refused to countenance that extravagance. She did not seem overcome by grief, and her plea of numerous offspring was really valueless, for, if anything, they were all better off than before. Her lord had been only a sham washerman, collecting the garments for her to wash, delivering them, and pocketing the returns, of which he gave her as small a moiety as would sustain life, and spent the rest on the cockpit.

Funerals in a country where there are no preservatives take place very soon. The lavandero died at dawn, his widow made her levy on me before seven o'clock, and, coming home that afternoon, I met the funeral in a thickly shaded lane.

Local tradition disapproves of the appearance of 


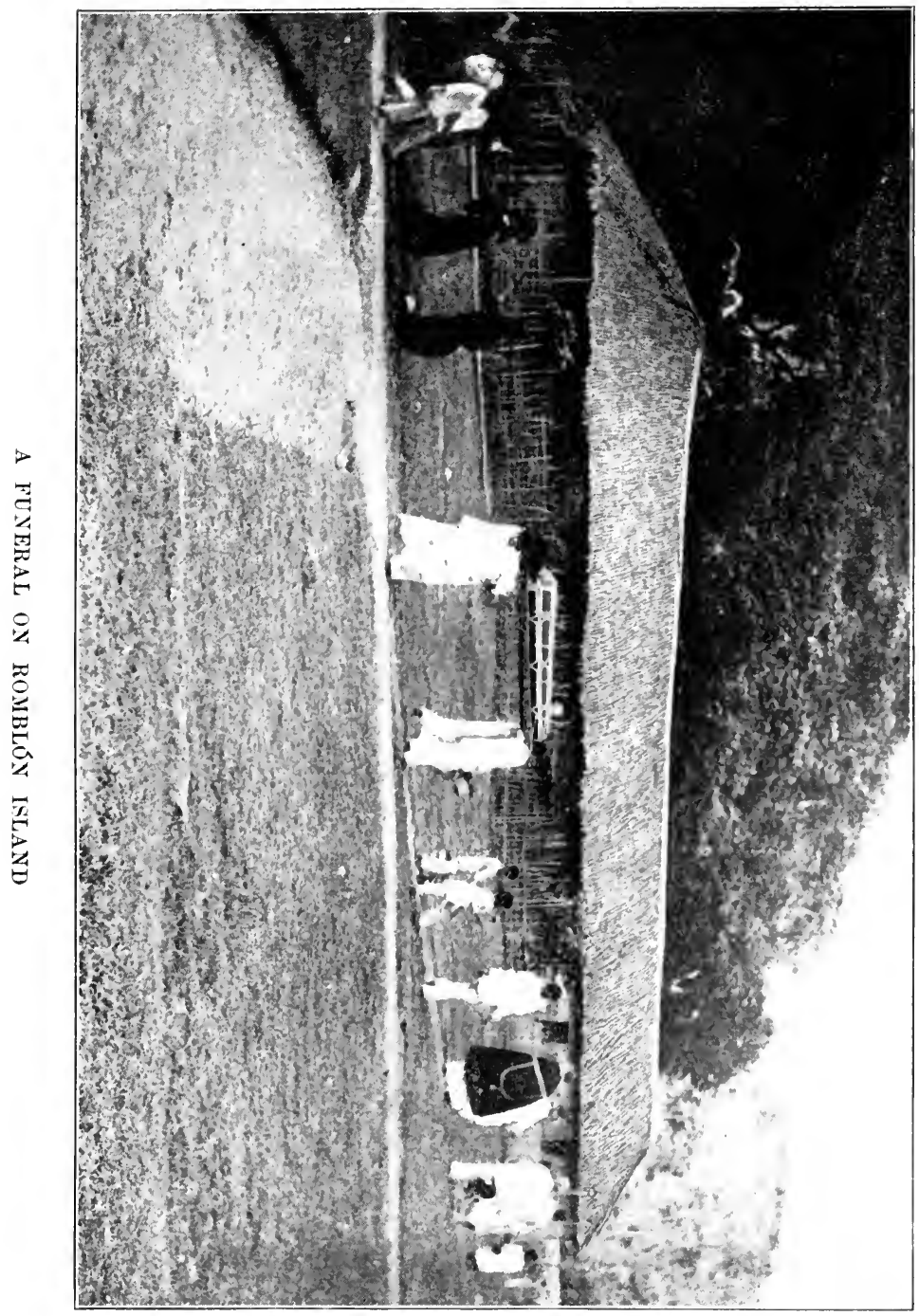



near female relations at a funeral, so the dead man's escort consisted only of the four bearers, and three small boys, all under eleven years of age. The coffin was one in general use - rented for the trip to the cemetery. Once there, the body, wrapped in its petate, or sleeping mat, would be rolled into a shallow grave.

The four bearers were dirty and were chewing betelnut as they trudged along under their burden. Behind them came the dead man's son, apparelled in a pair of blue denim trousers. His body, naked to the waist, was glistening brown after a bath, and he carried under one arm a fresh laundered camisa, or Chino shirt, of white muslin, to be put on when he reached the church.

His two supporters were the brothers of my muchacha, who lived in the same yard and who evidently had convictions about standing by a comrade in misfortune. The elder, a boy of seven, was fairly clean; but the younger, somewhere between three and five, was clad in a single low-necked slip of filthy pink cotton, which draped itself at a coquettish angle across his shoulders, and hung down two or three inches below his left knee. His smile, which was of a most engaging nature, occupied so much of his countenance that it was difficult to find traces of the pride which actually radiated from the other two.

My curiosity was enough to make me turn and follow them to the church. There the body was deposited on the floor at the rear, just below a door in the gallery which led to the priest's house, or convento. The bearers squatted on their heels and fell to wrapping 


\section{IMPRESSIONS OF THE PHILIPPINES}

up pieces of betel-nut in lime paste and buya leaf, while a sacristan went to call the priest. The dead man's son reverently put on his clean shirt, and the youngest urchin sucked his thumb and continued to grin at me.

Presently a priest came through the door and leaned over the gallery, followed by two sacristans, one bearing a censer and the other a bell. The censer-bearer swung his implement vindictively in the direction of the corpse, while the other rang a melodious chime on the bell. At this all the babies fell on their knees. The priest muttered a few lines of Latin, made the sign of the cross, and disappeared to another chime of the bells and a last toss of the censer. The bearers picked up the coffin, and the little procession went on its way to the cemetery. The ceremony lasted about one minute and a half, and consumed three out of my five pesos.

This incident illustrates neatly the friendless condition in which most Filipino poor live. Filipino lowerclass people are gregarious, but not sociable. They are averse to solitary rural life and tend everywhere to live in villages, but they visit little with each other, and seem very indifferent to the cordial relations which bind our own laboring classes together.

In the same yard with the dead lavandero lived at least ten or twelve other families, yet no one could be found to accompany him to his grave save two playmates of his son.

If the poor are fond of display, the rich outvie them. The pomp of a rich man's obsequies finds its beginning 
while he is yet on earth, when the padre goes in state to administer extreme unction. His vehicle, a gilt coach which looks like the pictures of those of the seventeenth century, is often preceded by a band, while the priest within is arrayed in embroidered vestments. When the surra, or horse disease, had made a scarcity of those animals, the padre's gilded equipage had to be drawn by a cebu, or very small and wearylooking cow, imported from Indo-China. The spectacle of this yoke animal, the gilt coach, and the padre in all his vestments was one not to be forgotten.

When the rich man dies, there is generally a wake, noisy enough, as before stated, to be Irish, and a pretentious funeral. Five o'clock in the afternoon seems to be a favorite hour for this. In the rainy season, with sodden clouds hanging low in the sky, with almond trees dripping down, and the great church starred with candles which do not illuminate but which dot the gloom, the occasion is lugubrious indeed. Fresh flowers are little used, but immortelles and set designs accompanied by long streamers of gilt-lettered ribbon attest the courtesy of friends.

They bury the dead - that is, all the upper-class dead - in nichos, or ovens, such as are found in the old cemeteries of New Orleans. The cemetery, which is usually owned, not by the municipality but by the church, is surrounded by a brick or stone wall six or eight feet high surmounted by a balustrade of red baked clay in an urn design. The ovens form their back walls against this, and are arranged in tiers of four or five, so that the top of the ovens makes a fine 


\section{8

promenade around three sides of the enclosure. In the centre there is generally a mortuary chapel, where the final words are said. From the chapel tiled walks lead out to the ovens. The plan is a very pretty one, and if the cemeteries were kept in good condition, it would be beautiful. But they are nearly always dirty and neglected.

In the open ground between the chapel and the sides, the poor people are rolled into graves so shallow that a little digging would soon exhume the body.

The nichos, or ovens, are rented by the year; if the tenant's surviving family are not prompt with the annual payment, the body is taken out, the bones cast ruthlessly over the back fence, and the premises once more declared vacant.

When we first came, there used to be a great heap of these bones at the back of the Paco Cemetery in Manila, but so much was said about them that the Church grew sensitive and removed them. Our cemetery at Capiz also had its bone heap.

An American negress, a dressmaker who was working for me, told me that there was a petrified man, an American, in the Paco Cemetery, and that the body was on exhibition. She had been to see it, and it was wonderful. I had my doubts about the petrifying, but as I had to pass the cemetery on leaving her house, I asked the custodian at the gate if there was such a body there. He said that the body had just been removed by the city authorities to be placed in the "Cemeterio del Norte," where there is a plot for paupers. The body was that of an American, buried 
in the cemetery five years before. His rent, five pesos a year, had been prepaid for five years, but his time had run out. When they came to take out the body, which had been embalmed, it was found in a remarkable state of preservation. The custodian said, with an irreligious grin, that in the old days the condition of the body would have been called a miracle, and a patron saint would have been made responsible, and all the people would have come, bearing lighted candles, to do honor to the saint; and he added regretfully that it was no good in these days. The Americans would say that it was because of their superior embalming process. "But what a chance missed!" he said, "and what a pity to let it go with no demonstration!" There are many ways of looking at the same thing. I could not help laughing, thinking of the negress. She said, "He's sittin' up there by the little church, lookin' as handsome as life - and him petrified!" 


\title{
CHAPTER TWENTY-ONE
}

\author{
SPORTS AND AMUSEMENTS
}

Dancing, Cock-fighting, Gambling, Theatricals - Sunday in the Philippines - Lukewarmness of Protestant Christians in the Philippines - How a Priest led Astray the Baptist Missionary's Congregation on Thanksgiving - Scarcity of Amusements in Provincial Life An Exhibition of Moving Pictures - Entertainments for the Poorer Natives - The Tragedy of the Dovecot.

7 HE Filipino's idea of a good time is a dance. Sometimes, in the country, a dance will go on

1 for forty-eight hours. People will slip out and get a little sleep and come back again. Next to the dance, the cock-fight is their chief joy. A cock-fight is, however, not a prolonged or painful thing. Tiny knives, sharp as surgical instruments, are fastened to each bird's heels, and the cock which gets in the first blow generally settles his antagonist.

Gambling is the national vice. The men gamble at monte and pangingue, and over their domino games, their horses, and their game-cocks. The women of both high and low class not infrequently organize a little card game immediately after breakfast and keep at it till lunch, after which they begin again and play till evening. Women also attend the cock-fights, especially on Sunday. Often the cockpit is in the rear of 
the church and the convento; and the padre derives a revenue from it.

Manila, being the metropolis, has its theatres, cinematograph shows, and music halls. Nearly every year there is a season of Italian opera, in which the principals are very good, and the chorus, for obvious reasons, small and poor. Most of the theatrical talent which wanders in and out comes from Australia. One theatre, which American women do not patronize, keeps a sort of music-hall programme going all year. There are many smaller theatres, where plays in the Tagalog language, the products of local talent, are presented. I cannot say what is the trend of these at the present time, but seven years ago the plots nearly all embraced bad Spanish frailes who were pursuing innocent Filipino maidens, and who always came to an end worthy of their evil deeds. The disposition to express racial and political hatreds in those plays was so strong that a friend in asking me to go naïvely pictured his conception of them in the invitation. He said, "Let's go over to the Filipino theatre and see them kill priests."

Of course, there is no Puritan Sabbath in the Philippines. Theatres, balls, and receptions are carried on without any observance of that day. The Protestant churches make a valiant effort to keep a tight rein over their flocks, but with little success. It cannot truthfully be said that most Americans here are either fond of church-going or fond of the church social, which, with its accompanying features of songs, recitations, and short addresses by prominent citizens, who were never designed by the Creator to speak in public, and 


\section{IMPRESSIONS OF THE PHILIPPINES}

its creature comforts of home-made cake and ice cream, has leaped the Pacific.

During my third year in Capiz a Baptist missionary arrived and took up his work. He seemed to feel that he had a claim upon all Americans to rally to his support. But, alas! they did not come up to his expectations. Some were Roman Catholics; others, of whom I was one, had an affection for the more formal, punctilious service of the Church of England; and even two or three nonconformist teachers realized that a too open devotion to the missionary cause would hopelessly endanger their usefulness as teachers.

So the missionary carried on his services for nearly a year, and no single American appeared at them. His congregation, which was largely recruited from the poorer classes, and which had been hoping for the social advantage which would be derived from the American alliance, naturally pressed the unfortunate missionary for a reason. The sorely tried man spoke at last. He said briefly that the Americans in Capiz were pagans.

On one occasion the missionary arranged a service for Thanksgiving morning and invited us personally. Of course we all said that we should be glad to go. But the astute padre of the Church Catholic was not going to have any such object lesson as that paraded before his flock. He arranged for the singing of a Te Deum in honor of the day at half-past nine, just half an hour before the time set for the other service. Then he got the Filipino Governor to send out written invitations from his office in such a way that the affair as- 


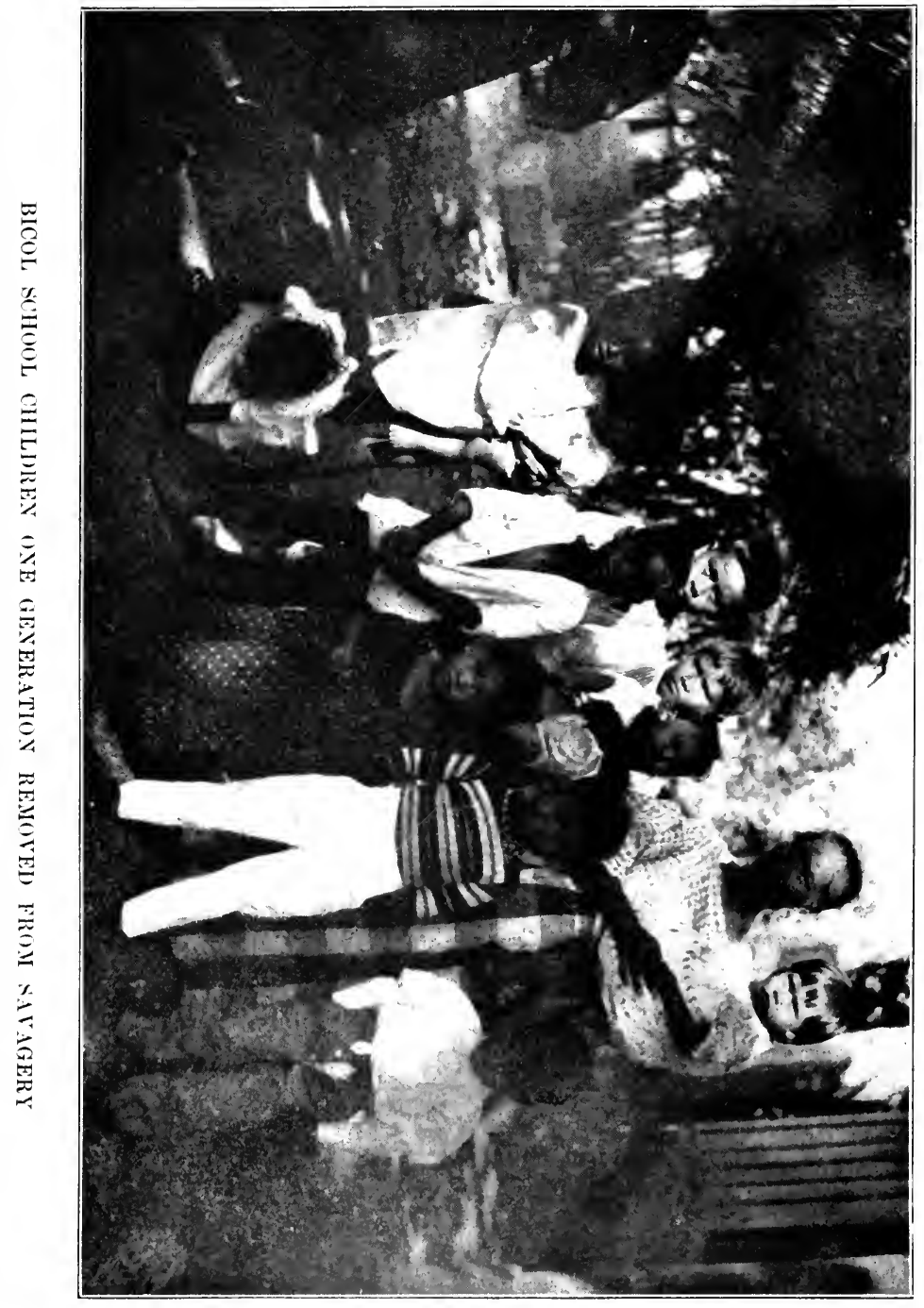



sumed the complexion of a national courtesy offered by the Filipino to the American. For us, as Government employees, to disregard this was impossible. So we went en masse to the Roman Catholic church, where two rows of high-backed chairs were arranged facing each other up the centre of the church for our high mightinesses.

We had agreed privately that after the Te Deum we would go over to the Protestant chapel, and not leave the poor missionary to feel himself wholly deserted. But no opportunity came. The service was prolonged till any hope of our appearing in the rival chapel was effectually quashed. When we came out, we looked at one another and burst out laughing. It was one more evidence that the American is no match for the Filipino in finesse.

Naturally, unless one falls in with the Filipino devotion to dancing, there are few sources of so-called amusement in provincial life. The American women visit each other and give dinners, which, to the men who live in helpless subjection to an ignorant native cook, are less a social than a gastronomic joy. If we are near the seashore, we make up picnics on the beach, swim, dig clams, and cook supper over a fire of driftwood. If thirst overtakes us, we send a native up a tree for green cocoanuts. He cuts a lip-shaped hole in the shell with two strokes of his bolo, and there is water, crystal clear and fresh. The men hunt snipe and wild ducks, and sometimes wild pigs and deer.

In default of travelling theatrical companies, the provincial natives have their own organizations of 
local talent and present little plays in either Spanish or the native tongue. If American troops are stationed near a town, there will be one or two minstrel shows each year. The Filipinos all go to these, but they don't understand them very well and are not edified. I think they imagine that the cake walk is a national dance with us, and that the President of the United States leads out some important lady for this at inaugural balls.

Once in a while a travelling cinematograph outfit roams through the provinces, and then for a tariff of twenty-five cents Mexican we throng the little theatre night after night. I remember once a company of "barn-stormers" from Australia were stranded in Iloilo. They had a moving picture outfit, and a young lady attired in a pink costume de ballet stood plaintively at one side and sang, plaintively and very nasally, a long account of the courting of some youthful Georgia couple. The lovers embraced each other tenderly (as per view) in an interior that had a "throw" over every picture corner, table, and chair back. Some huge American soldier down in the pit said, "That's the real thing; no doubt about it," but whether his words had reference to the love-making or the room we could not tell.

The song went on, the lovers married and went North; but after awhile the bride grew heartsick for the old home, so "We journeyed South a spell." With this line the moving picture flung at us, head on, a great passenger locomotive and its trailing cars. To the right there were a country road, meadows, some distant hills, a stake and rider fence, and a farmhouse. The scene 
was homely, simple, typically American, and rustic, and it sent every drop of loyal American blood tingling. The tears rushed to my eyes, and I could n't forbear joining in the roar of approbation that went up from the American contingent. An Englishman who was with our party insisted that I opened my arms a yard and a half to give strength to my applause. I said I did n't regret it. We poor expatriated wanderers had been drifting about for months with no other emotion than homesickness, but we had a lively one then. The Filipino audience at first sat amazed at the outburst; but their sympathies are quick and keen, and in an instant they realized what it meant to the exiles, and the wave of feeling swept into them too. The young lady in the pink costume grew perceptibly exalted, and in the effort to be more pathetic achieved a degree of nasal intonation which, combined with her Australian accent, made her unique.

The poorer natives have one source of enjoyment in a sort of open-air play which they call colloquio. This is always in the hands of local talent, and is probably of Spanish mediæval origin. The three actors are a captive princess, a villain, and a true knight. The villain is nearly always masked, and sometimes the princess and knight are masked also. The costuming is European. The performance may take place in a house if anybody is kind enough to offer one, but more frequently the street is the scene. A ring is marked off, and the captive princess stands in the middle, while knight and villain circle about her with their wooden swords, countering, and apparently making up verses 


\section{IMPRESSIONS OF THE PHILIPPINES}

and dialogue as they go along. When they get tired, the princess tells her sorrowful tale. The people will stand for hours about a performance of this sort, and for weeks afterwards the children will repeat it in their play.

Once a circo, or group of acrobats, came to Capiz and played for over a month to crowded houses. The lowclass people and Chinese thronged the nipa shack of the theatre night after night from nine P. M. till two $\mathrm{A}$. M. When a Filipino goes to the theatre, he expects to get his money's worth. I myself did not attend the circo, but judging from what I saw the children attempt to repeat, and one other incident, I fancy it was quite educative.

The other incident has to do with my henchman, Basilio, previously mentioned, who later arrived at the dignity of public school janitor. Basilio had been a regular patron of the circo, so much so that he came into my debt. One of the first things we had set ourselves to do was the clearing up of all school grounds and premises by pupil labor. Exactly in the middle of the back yard of the Provincial School was a great dovecot, which spoiled the lawn for grass tennis courts. So our industrial teacher decided to move the dovecot bodily to another place. I doubted if it could be accomplished without somebody's getting hurt, and Basilio, without offering any reason, vociferously echoed my sentiments, and jeered openly at the idea of the industrial teacher's getting that dovecot safe and sound to the other end of the yard.

I refused to risk the Provincial School boys on the 
task, so the teacher borrowed a file of prisoners from the Provincial jail. Basilio the incredulous was ordered to be on hand and to make himself useful. He appeared in a pair of white duck trousers, the gift probably of some departing American, and somebody's discarded bathing shirt in cherry and black stripes. He had cut off the trousers legs at the thighs, and, with bare arms and legs glistening, was as imposing an acrobat as one could wish to see.

I had long wanted a swing put up in a great fire-tree which stood near the dovecot, and while the prisoners were loosening the earth about the four supporting posts, I sent Basilio to put it up. He finished his work just as the prisoners were ready to heave up on the posts, and, to express his entire glee in what was shortly to occur, he came down the rope à la circo, and landed himself with a ballet dancer's pirouette, kissing both hands toward the tugging men. Anything more graceful and more comical than Basilio's antics, I have never seen.

The dovecot was supported, as I said, by four great posts sunk in the ground. On top of these was a platform, and on the platform rested the house. The American teacher had assumed that the platform was securely fastened to the posts and that the house was nailed to the platform. This was his great mistake. He had not been over very long, and he could n't make allowance for the Filipino aversion for unnecessary labor. The dovecot would hold firm by its own weight, and the builders had not seen the necessity of wasting nails and strength. 
Basilio with outstretched arms continued to stand on his toes while the prisoners grunted over the posts, which came up with difficulty. They were shamelessly lazy and indifferent to the commands of the industrial teacher, who had, however, the sagacity to get out of range himself. They lifted unevenly, there was a tipping, a sliding, and a sinash, as by one impulse the prisoners jumped aside and let house, platform, and posts come thundering to the ground. Feathers drifted about like snow; there were wild flutterings of doves; and squabs and eggs spattered the lawn.

When I saw that nobody was hurt, I joined in the cackles of the prisoners, who were doubled up with joy at the discomfiture of the American teacher. He was in a blind rage, which was not diminished by the outcries and lamentations of the Governor and a horde of clerks, who swarmed out to express their grief over the wanton destruction of a landmark. Privately, I don't believe they cared a rap, but the opportunity to reproach an American for bad judgment comes so seldom to the Filipinos that they refuse to let it escape.

Basilio never moved a muscle when the crash came. He had stood buoyantly expectant; he received it flamboyantly calm. A smile of ineffable pleasure then seized upon his features, and with the breaking forth of the chorus he rose to joyous action. He spun on his heels like a dervish. He threw handsprings, he walked on his hands, he exhausted, in short, all that he had been able to acquire in the abandon of the previous weeks; and then gravely righting himself, he went over 


\section{SPORTS AND AMUSEMENTS}

and began to pick up squabs. These he offered to the American with a perfectly wooden countenance, and with the simple statement that they were very good eating. He acted as if he thought the teacher had done it all for that purpose. 


\section{CHAPTER TWENTY-TWO}

CHILDREN'S GAMES - THE CONQUEST OF FIRES

Children's Games - How Moonlight Nights are enjoyed -

The Popularity of Baseball among the Filipinos My Domestics play the Game - The Difficulty of PUtTing out Fires - Need of Water-storage for the Dry Season - Apathy of the Public at Fires - Examples showing the Loyalty aNd Devotion of ServaNTS WHEN Fires occur.

$\mathrm{F}$

ILIPINO children are not so active as the children of our own race, and their games incline to the sedentary order. Like their elders, they gamble; and like all children, the world over, they have a certain routine in which games succeed one another. At one season in the year the youngsters are absorbed in what must be a second cousin to "craps." Every child has some sort of tin can filled with small spotted seashells. They throw these like dice; they slap their hands together with the raking gesture of the crapplayer, and utter ejaculations in which numeral adjectives predominate, and which must be similar to "lucky six" and kindred expressions.

Following the crap game there is usually a səason of devotion to a kind of solitaire which is played with shells on a circular board, scooped out into a series of little cup-like depressions. They will amuse themselves 
with this for hours at a time. The shells are moved from cup to cup, and other shells are thrown like dice to determine how the shells are to progress.

The commonest form of child gambling, however, is that of pitching coppers on the head and tail plan. You may see twenty or more games of this sort at any time around a primary school. Sometimes the game ends in a fight. Sometimes the biggest urchin gathers up everything in sight and escapes on the ringing of the bell, leaving his howling victims behind.

Not unnaturally, in consideration of the heat, there is comparatively little enthusiasm for rough sport. The only very active play in which little boys and girls engage, is leap frog, which differs slightly from the game in our own country.

Two children sit upon the ground and clasp their right hands. A leader starts out, clears this barrier, and all the rest of the players follow. Then one of the sitting children clasps his unoccupied left hand upon the upraised thumb of his companion, thus raising the height of the barrier by the width of the palm. The line starts again and all jump this. Then the second sitter adds his palm and thumb to the barrier, and the line of players attack this. It is more than likely that some one will fail to clear this last barrier, and the one who does so squats down, pressing close to the other two, and puts in his grimy little paw and thumb. So they continue to raise the height of the barrier till, at last, nobody can jump it.

When they play drop the handkerchief, Filipino children squat upon their heels in a circle instead of stand- 


\section{IMPRESSIONS OF THE PHILIPPINES}

ing. They have also the familiar "King William was King James's Son "; I do not know whether the words in the vernacular which they use are the equivalent of ours or not. The air, at least, is the one with which we are all familiar.

They have one more game which seems to be something like our hop-scotch but more complicated. The diagram, which is roughly scratched out on the ground, is quite an extensive one. The player is blindfolded, and hops about, kicking at his bit of stone and placing it in accordance with some mysterious rule which I have vainly sought to acquire. The children play this in the cool, long-shadowed afternoons, when they have returned from school, have doffed their white canvas shoes and short socks, and have reverted to the single slip of the country.

There is a local game of football which is played with a hollow ball or basket of twisted rattan fibres. The players stand in a ring, and when the ball approaches one, he swings on one heel till his back is turned, and, glancing over his shoulder, gives it a queer backward kick with the heel of his unoccupied foot. It requires some art to do this, yet the ball will be kept sometimes in motion for two or three minutes without once falling to the ground.

On moonlight nights the Filipinos make the best of their beautiful world. The aristocrats stroll about in groups of twenty, or even thirty, the young people snatching at the opportunity to slip into private conversation and enjoy a little solitude à deux while their elders are engrossed in more serious topics. The com- 


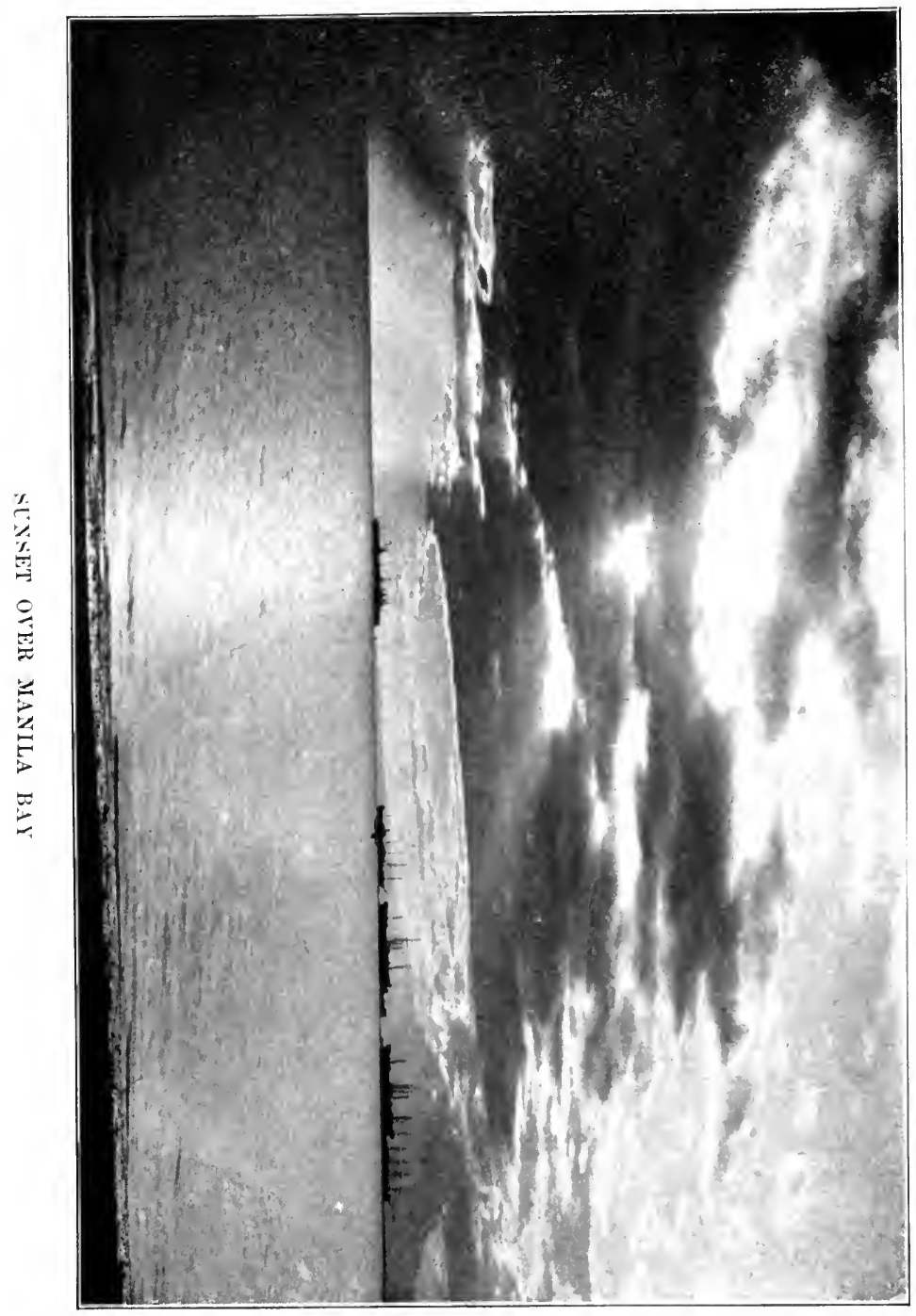



mon people enjoy a wholesome romp in a game which seems to be a combination of "tag" and "prisoner's base." Groups of serenaders stroll about with guitars and mandolins, and altogether a most sweet and wholesome domesticity pervades the village.

At present the nearest real bond between American and Filipino is baseball - "playball" the Filipinos call it, having learned to associate these words with it from the enthusiastic shouts of American onlookers. Baseball has taken firm hold, and is here to stay. In Manila every plot of green is given over to its devotees. Every secondary school in the country has its nine and its school colors and yell, and the pupils go out and "root" as enthusiastically as did ever freshmen of old Ýale or Harvard. No Fourth of July can pass without its baseball game.

We had a good baseball team at Capiz as early as 1903, and played matches with school teams from neighboring towns. I did not realize, however, how popular the game had become until one warm afternoon, when I was vainly trying to get a nap.

The noise under my window was deafening. Thuds, shrieks, a babble of native words, and familiar English terms floated in and disturbed my rest. Finally I got up and went to the window.

The street was not over twenty-five feet wide, the houses, after native custom, being flush with the gutter. In this narrow space my servants had started a game of ball. They had the diamond all marked out, and one player on each base. There was Ceferiana, the cook, a maid of seventeen, with her hair twisted 


\section{IMPRESSIONS OF THE PHILIPPINES}

into a Sappho knot at the back with one wisp hanging out like a horse's tail. Her petticoat was wrapped tightly around her slim body and its back fulness tucked in at the waist. She was barefooted, and her toes, wide apart as they always are when shoes have never been worn, worked with excitement. There was Manuel, who skated the floors, an anæmic youth of fifteen or sixteen, dressed in a pair of dirty white underdrawers with the ankle strings dragging, and in an orange and black knit undershirt. There was Rosario, the little maid who waited on me and went to school. She was third base and umpire. A neighbor's boy, about eight years old, was first base. Manuel was second base and pitcher combined. Ceferiana was at the bat, while behind her her youngest brother - he whose engaging smile occupied so much of my attention at the funeral of the lavandero aforementioned was spread out in the attitude of a professional catcher. His plump, rounded little legs were stretched so far apart that he could with difficulty retain his balance. He scowled, smacked his lips, and at intervals thumped the back of his pudgy, clenched fist into the hollowed palm of the other hand with the gesture of a man who wears the catcher's mitt. Had a professional baseball team from the States ever caught sight of that baby, they would have secured him as a mascot at any price.

The ball was one of those huge green oranges which the English call pomeloes, about twice the size of an American grape-fruit. Being green, and having a skin an inch thick, it withstood the resounding thwacks of 
the bat quite remarkably. It was fortunate that the diamond was so small, for it would have taken more strength than any of the players possessed to send that plaything any distance. Catching it was only the art of embracing. It had to be guided and hugged to the breast, for it was too big to hold in the hands. The valorous catcher, in spite of his fiercely professional air, invariably dodged it and then pursued it.

The bat was a board about eight inches wide, wrenched from the lid of a Batoum oil case and roughly cut down at one end for a handle. With the size of the ball and the width of the bat, missing was an impossibility. It was only a question of how far the strength of the batter could send the ball. When it was struck, everybody ran to the next base, and seemed to feel if he got there before the ball hit ground, he had scored something.

Rosario, as I said, was both third base and umpire (after a run they always reverted to their original positions). Her voice rang out in a symphony like this: "Wan stri'! Wan ball! Fou' ball! Ilapog! ilapog sa acon! Hindi! Ilapog sa firs' base! Fou' ball."

At times when somebody on a base made a feint of stealing a run ( for they were acting out everything as they had seen it done at the last public match), Manuel threatened all points of the compass with his four-inch projectile, and again the voice of Rosario soared, "Ilapog - Ilapog sa firs' base-Hindi! sa Ceferiana! ah (ow-ut)!" while an enthusiastic onlooker who had set down a bamboo pipe filled with tuba dulce 


\section{IMPRESSIONS OF THE PHILIPPINES}

(the unfermented sap of the nipa palm or the cocoanut tree) added his lungs to the uproar in probably the only two English words he knew - "Play ball! play ball!"

Thus are the beginnings of great movements in small things. Those children got more real Americanism out of that corrupted ball game than they did from singing "My Country, ' $t$ is of Thee" every morning.

From a baseball game to a fire is a far cry, but fire in the Philippines has such distinctive features that I cannot pass it without a word. The lack of all facilities for combating it makes it an ever present menace. The combustible materials of which houses are built, and their close crowding together, tend to spread it rapidly; while the thatched roofs make even the burning of an isolated house a danger to the entire community.

Manila has an up-to-date American fire department, but even there, with water mains and a signal-box system for alarms, a fire once started in a nipa district in the dry season can seldom be checked until the neighborhood is clean swept. In the provinces, where there is not so much as a bucket brigade, the first alarm sends everybody's heart into his mouth.

The chief trouble is the lack of water for putting out a fire in its incipiency. Never was there a land in which water was more abundant or more scarce than it is in the Philippines. For five months of every year the skies let down a deluge, but nothing appreciable 
of all the downfall is saved. The rich - the haughty, ostentatious rich - have great masonry tanks walled up at the ends of their houses, capable of holding two or three thousand gallons of water. With the contents of these tanks the rich people supply themselves with drinking water during the dry season, and net a considerable income from its sale to their less fortunate neighbors. The merely well-to-do people content themselves with a galvanized iron tank, which may store from two to six hundred gallons, which is seldom enough to last out the dry season. In this case they buy water from the mountaineers, who fill their tinajas, or twenty-gallon earthenware jars, with water from mountain springs, and bring them to the nearest towns in bancas.

The poor people have no way whatever of storing rain-water, and either beg a few quarts each day from the rich people to whom they are feudally attached, or else they fall back upon the ground wells, or pozos, which, even they know, breed fevers and dysentery.

By no means every house has its well. Sometimes there are only two or three to a block. Sometimes the well is merely a shallow hole, uncemented, to catch the seepage of the upper strata. Sometimes it is a very deep stone-walled cavity. Rarely is there a pump or a windlass or any other fixed aid for raising the water.

When a fire starts, therefore, with such an inadequate water supply, nothing can be done except to tear down communicating houses or roofs. Enterprising natives who live even at a considerable dis- 


\section{8

tance, usually mount their ridge-poles and wet down their roofs if they can get the water with which to do it.

In the immediate vicinity of the fire itself tumult reigns. Filipino womankind, who are so alluringly feminine, are also femininely helpless in a crisis, and if there be no men around to direct and sustain them, often lose their heads entirely. They give way to lamentations, gather up their babies, and flee to the homes of their nearest relatives. Often they forget even their jewels and ready money, which are locked in a wardrobe.

Meanwhile, if there be men folks about, they make a more systematic effort to save things, and as all relatives and connections who are out of danger themselves rush in at the first alarm, quite a little may be rescued. The things which are traditional with us as showing how people lose their heads at a fire are just as evident here as in our own land. They throw dishes, glassware, and fine furniture out of the windows, and carry down iron pots and pillows. The poor gather their little store of clothing in sheets, release the tethered goats, puppies, game-cocks, and monkeys, which are always abundant about their shacks, and toddle off with their doll trunks in their arms. The sight is a pitiful one, especially when the old and decrepit, of which almost every house yields up one or more, are carried out in hammocks or chairs. Yet in a few hours all will have found shelter with friends, and probably the suffering consequent upon a fire is less than in our own country, where people have 
more to lose and where the rigor of climate is a factor not to be overlooked.

There is very little use in combating fire under such circumstances, and perhaps long experience has contributed to the apathy with which such disasters are treated. The American constabulary and military officials generally turn out their men, and lend every effort themselves to quell the flames. Here and there individual Filipinos, such as governors or presidentes, who feel the pressure of official responsibility, display considerable activity; but, on the whole, the aristocratic, or governing, class rather demonstrates its weakness at such times. The men whose property is not threatened seldom exert themselves, but stand in groups and chatter about how this could be done or that. Everybody is full of suggestions for somebody else to execute, but nobody does anything. The municipal police nose about in the crowd, and at intervals seize upon some obscure and inoffensive citizen, propelling him violently in the direction of the conflagration with orders to "work." He half-heartedly picks up an old five-gallon petroleum can or a bamboo water-pipe, and starts off to the nearest well, but as soon as he is -out of range of the policeman's eye he drops the article, shuffles back into the gazing crowd, and does no more work.

At such time the loyalty and devotion of servants are put to a severe test. Two incidents came under my notice which it is a pleasure to describe. During my third year at Capiz our own home (I was "messing" with another American woman teacher) was 
threatened by fire one night, and all our household goods were carried out and saved by American men. The house was on fire more than once, but they managed to extinguish the fire each time.

Mention has previously been made of my little maid, Ceferiana. At the first alarm that night, she rushed into my room, and, spreading out a sheet, began to throw clothes into it from my drawers and wardrobe. When she had gathered up a full bundle, she rushed off to a place of safety, deposited it and came back for more. Meanwhile I had gathered up some silver and other valuables, and locked them in a trunk. Ceferiana helped me to carry this out, and as we were returning, the sweep of the flames seemed to be almost engulfing our house. For the first time Ceferiana gave a thought to her own possessions. With a wail - "Ah, Dios mio, mi ropa!" ("Oh, my God! my clothes!") - she sank down on her knees, beating her breast, and bewailing the loss of a wardrobe made up chiefly from my cast-off garments, but even then far richer than that of most girls of her class.

About this time the American men began to arrive on the scene, and though they would not permit us to return to the house, they chivalrously rescued Ceferiana's possessions as well as mine.

The lady who lived with me had some time before discharged a servant for a cause which we others considered not very just. She was timid, and as her husband was away, she was unwilling to permit the servant to leave the premises for even a brief time. Filipino servants simply cannot be handled in that 
way. A certain amount of time for recreation and pleasure is their just due, and they will have it. Adolphus, robbed of his paseo, reported that his grandmother was dying, and demanded an evening off to visit her. His mistress happened to take a walk that evening and beheld Adolphus the perfidious, not sitting by a dying grandmother, but tripping the light fantastic in a nipa shack, eight by twelve. She forthwith discharged Adolphus, and even levied on the services of a friendly constabulary officer to thrash him with a stingaree, or sting ray cane. Adolphus retaliated by forging her husband's name to some chits for liquors. She had him arrested, prosecuted, and jailed. He had just finished his sentence when the fire came. He was almost the first person to appear, and worked like a Trojan for two hours, his services being of no mean value. I think the reader will agree with me that Adolphus showed a Christian and forgiving spirit. 

RETURN TO the circulation desk of any

University of California Library

$$
\text { or to the }
$$

NORTHERN REGIONAL LIBRARY FACILITY

Bldg. 400, Richmond Field Station

University of California

Richmond, CA 94804-4698

ALL BOOKS MAY BE RECALLED AFTER 7 DAYS

2-month loans may be renewed by calling

(510) 642-6753

1-year loans may be recharged by bringing books to NRLF

Renewals and recharges may be made 4 days prior to due date

DUE AS STAMPED BELOW

\section{RECEIVED}

OCT $; 81996$

CIRCULATION DEPT.

\section{MAY 151997 \\ DEC 172005}


YB 2874l,

\section{GENERAL LIBRARY - U.C. BERKELEY}

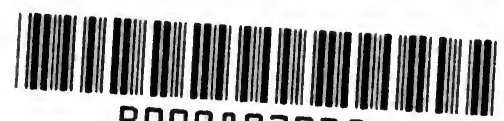
B000897925

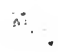

$\therefore \quad \because$

\section{* 268954}
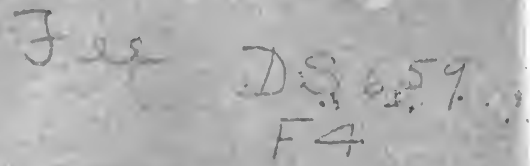

UNIVERSITY OF CALIFORNIA LIBRARY - 3 inar a.... 
